\title{
The Dawn of a New
}

Constructive

Era

\section{UC-NRLF}

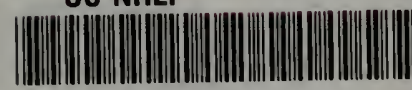

B 4523690

\section{MPOCKTEINGS OF TME \\ GUT DVER LANO GONEEREYOE \\ OF THE SOUTH}

New Orleans, Lea. April 11, 12 and 13,1917 

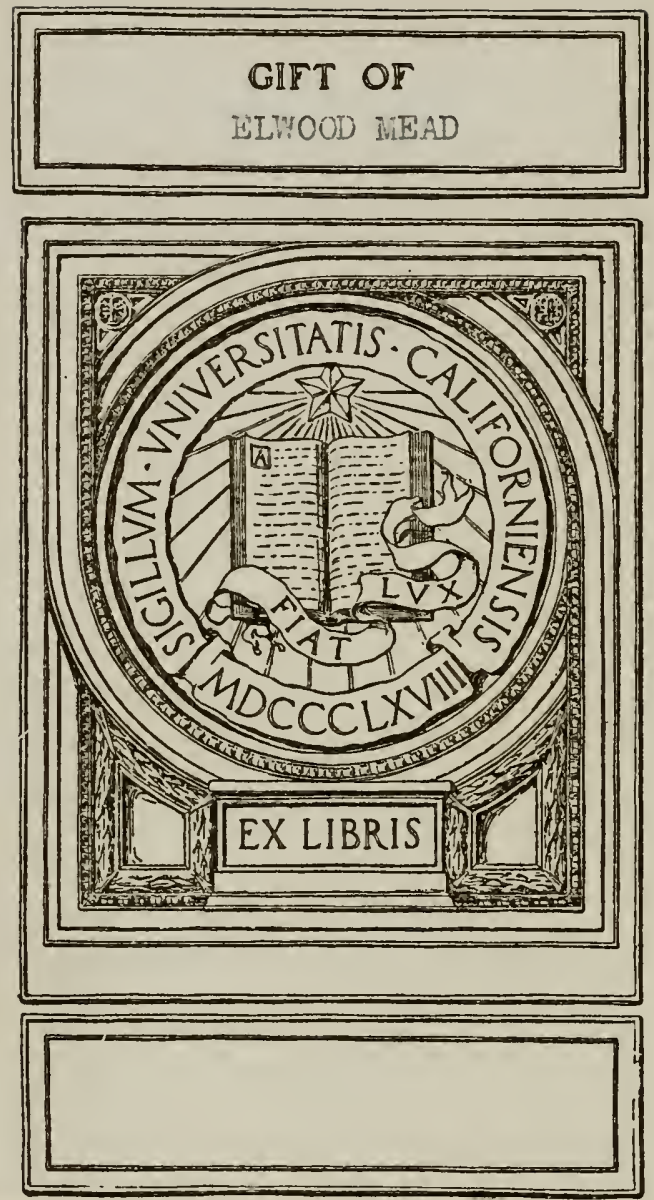



\section{"The Dawn of a New Constructive Era's}

Being the Full and Complete Report of the

Cut-Over Land Conference of the South

Held Under the Auspices of the Southern Pine Association; Southern Settlement and Development Organization; New Orleans Association of Commerce;

In Co-operation with the United States Department of Agriculture; Department of the Interior; Southern State Agricultural Colleges and Experiment Stations. 


\section{Looking Ahead}

T $N$ presenting this book to the public the publishers are inspired by a desire to make permanent record of the fund of information embraced in the addresses of a number of prominent men who gathered in New Orleans April 11, 12 and 13, 1917, to participate in the "Cut-Over Land Conference of the South." This meeting was called for the purpose of discussing the question of best present and future beneficial use for stock raising, agriculture and reforestation to which there might be placed unillions of acres now lying idle throughout a large part of the South, and was attended by many land owners, agricultural experts of the Federal and State governments, and others.

It is also desired that the volume serve as the record of the first definite steps taken in a work which is expected to become the greatest constructive development movement ever undertaken in the United States.

Lumber manufacturers, who own much of the cut-over lands. are looking forward to the day when their mill operations will be curtailed by the diminution of the virgin pine forests. Meanwhile, they wish to take steps to convert into practical service for the benefit of themselves and the public the vast empire of territory now largely unproductive. The Southern Cut-Over Land Association is an organization which has grown out of the Cut-Over. Land Conference, held under the joint auspices of the Southern Pine Association and Association of Commerce of New Orleans and the Southern Settlement and Development Organization, of Baltimore, Md., and has now actively entered on the task of consummating this great undertaking.

SOUTHERN CUT-OVER LAND ASSOCIATION,

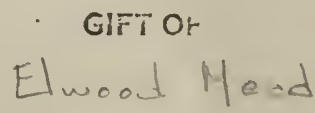




\section{Table of Contents}

Section I-Proceedings of Wednesday, April 11, 1917.

Morning Session-Mr. M. L. Alexander Presiding Page

"A Foreword". . ..................... 7

By Mr. J. Lewis Thompson, Chairman, Cut-Over Land

Committee, Southern Pine Association

"Why We Have Met"..................... 8-10

Address ly Mr. M. L. Alexander, Commissioner, Lonisiana

State Conservation Commission

"Address of Welcome"

By Hon. Martin Behrman, Mayor of New Orleans

"Importance of Agricultural Development to the Cities".... 12-15

Address by Mr. Ernest Lee Jahncke, President of the

New Orleans Association of Commerce

"Practical Reforestation".

Paper prepared by Mr. Henry S. Graves, Chief Forester,

United States Forest Service, and read by Mr. E.

S. Bryant of the United States Forest

Service, representing Mr. Graves

"Practical Utilization of Cut-Over Lands".

Address by Mr. Stanley F. Morse, Agricultural Expert,

formerly of the University of Arizona

Afternoon Session-Mr. M. L. Alexander Presiding

"Agriculture From A National Standpoint"...........29-36

Address by Honorable Carl Vrooman, Assistant Secretary of Agriculture, United States Department of

Agriculture

"The Cut-Over Land Owner's Responsibility-His

Opportunity". . . ...................... $36-46$

Address by Hon. H. Clay Tallman, Commissioner, General

Land Office. United States Department of the Interior

"Lumbermen's Activities, Past, Present and Future"......46-50

Address by Mr. J. Lewis Thompson

"The Railroad's Part in the South's Development"........50-54

Address by Mr. J. C. Clair, Industrial Commissioner of the Illinois Central Railroad

Section II-Proceedings of Thursday, April 12, 1917.

Morning Session-Mr. Clement S. Ucker Presiding

"The Practical Aspects of the Problem"..............55-58

Address by Mr. Clement S. Ucker, Vice-President Southern

Settlement and Development Organization

"Natural Resources of the South-Arkansas as a Developing

Factor". . . . . . . . . . . . . . . . .

Address by Hon. Charles H. Brough, Governor of

Arkansas 
"Soils of the Coastal Plain Area".

Address by Mr. C. F. Marbut, Soil Expert, Bureau of

Soils, United States Department of Agriculture

"Some Factors to be Considered in the Drainage of the Cut-

Over Lands of the South" ...................78-83

Address by Mr. S. H. McCrary, Assistant Chief, Office of Public Roads and Rural Engineering, United States Department of Agriculture

\section{Afternoon Session-Mr. Clement S. Ucker Presiding}

"Some Problems of Cut-Over Land Development"........ 84-86

Address by Mr. Harry D. Wilson. Commissioner of

Agriculture of the State of Louisiana

"Forage Problem of the Coastal Plain Area".

Address by Dr. C. V. Piper, Chief Agrostologist, Bureau of Plant Industry, United States Department of Agriculture

"Experiences in Cattle Raising on Cut-Over Lands". . . . . . 93-96

Address by Mr. F. B. Enochs, of Fernwood, Miss.

"Soil Improvement Crops".

Address by Mr. S. M. Tracy, Agronomist, Office of Forest

Crop Investigation, United States Department of Agriculture

"Need of Experiment Station Work on Cut-Over Lands". . 103-106

Address by Mr. W. R. Dodson, Director of the State

College and Experiment Station of the State of Louisiana

"Mississippi's Part in Cut-Over Land Development"..... 106-107

Address by Dr. E. R. Lloyd, Director of Experiment Stations of the State of Mississippi

"What Georgia is Doing to Encourage the Utilizing of Cut-

Over Lands". . . . . . . . . . . . . . . . . . . . 108-111

Address by Mr. John R. Fain, Agronomist of the College of Agriculture of the State of Georgia

"Beef Cattle and Hogs". . . . . . . . . . . . . . . . 112-125

Address by Mr. George M. Rommel, Chief, Animal Hus-

bandry Division United States Department of Agriculture

"A Survey of the Live Stock Situation".

Address prepared by Dr. Andrew M. Soule, President of the College of Agriculture of the State of Georgia

"The Animal Industry of the South-Past, Present and

Future". . . . . .................... 142-150

Address by Dr. W. H. Dalrymple, Professor of Veterinary Science, Louisiana Agricultural College

“The Railroads' Interest in Cut-Over Land Development”. . 151-155

Address by Mr. D. C. Welty, Commissioner of Agriculture,

St. Louis, Iron Mountain and Southern Railway

"What Florida is Doing in Land Development"......... 155-157 Address by Mr. James F. Murphy; President of the Florida

Land Development and Colonization Association 


\section{Table of Contents-Concluded}

\section{Section III-Proceedings of Friday, April 13, 1917.}

Morning Session-Mr. Clement S. Ucker Presiding Page

"Demonstration Work on Cut-Over Lands"..........157-168

Address by Mr. G. E. Nesom, Superintendent of Live

Stock Extension Work in Lonisiana for the United

States Department of Agriculture

"How Louisiana is Solving the Reforestation Problem".... 169-172

Address by Mr. M. L. Alexander, Commissioner, Louisiana

State Conservation Commission

"Some Problems of Colonizing Cut-Over Lands".

$172-173$

Address by Mr. H. Q. Weare, of Mobile, Ala.

"The Dairy Industry of the South"............174-178

Address by Mr. C. W. Radway, Dairy Specialist, Bureau of

Animal Industry, United States Department of Agriculture

"Some Suggestions for Dairying on Cut-Over Lands". ... . 179-181

Address by Mr. N. P. Hull, President of National

$$
\text { Dairy Únion }
$$

"Tick Eradication".

Address by Dr. E. I. Smith, of the Bureau of Auimal

Industry, United States Department of Agriculture

\section{Afternoon Session-Mr. Clement S. Ucker Presiding}

"Stumps and Their Practical Removal".............. 188-195

Address by Mr. Carl D. Livingston, University of

Wisconsin, Madison, Wisconsin

"The Sheep Industry of the South".

Address by Mr. F. R. Narshall, Senior Animal Huslrandman, Bureau of Animal Industry, United States

Department of Agriculture

"Possibilities of Cut-Over Lands".

$.201-207$

Address by Mr. J. A. Evans, Assistant Chief, States Relation

Service, United States Department of Agriculture

"The Cut-Over Acre-IVhat is It Worth?"...........207-209

Address by Mr. William R. Lighton, Fayetteville. Ark.

"Shortage of Raw Materials-The Demand Increasing". .210-216

Address by Mr. A. C. Bigelow, President. Philadelphia

Wool and Textile Association

"Forestry and Cattle Raising on the Cut-Over Pine Lands

of the Southern States"................217-225

Address by Major J. G. Lee, Department of Forestry and Horticulture, Louisiana State University"

"The Necessity for Organized Effort".............226-229

Address by General L. C. Boyle, of Kansas City

"Cut-Over Lands and Their Value"...............230-231

Address by Mr. C. C. Prescott, Agricultural Agent,

Southern Railway Systen Development Service

Resolutions.

Senator Ransdell Sends Greetings.............. 236

Registration List. . . . . . . . . . . . . . . . . . . . 237-244 



\section{A Foreword}

\section{By J. Lewis Thompson \\ Chairman, Cut-Over Land Committee \\ Southern Pine Association}

Gentlemen:-We are gathered together here this morning in a conference-our program states just what we are here for; and on account of my having, in an unguarded moment, accepted the chairmanship of this committee I happen to be before you just at this time. We had expected to have a large gathering, and to all of you is due some explanation as to why we had so many changes in our date of meeting. The Department at Washington and the officials are very much interested in this meeting, and we were Government Deeply Interested in CutOver Land Development shifting about dates trying to arrive at a date at which they could attend, but, as we all know, the Germans interfered with their plans ; but we have finally gotten together here at this time. We are disappointed in not having Senator Ransdell here to preside for us this morning, but Mr. Alexander has kindly consented to preside, and I take pleasure in introducing Mr. Alexander to you. 


\section{Why We Have Met By M. L. Alexander Commissioner, Louisiana Department of Conservation}

Gentlemen :-I consider it an honor and a privilege to be called upon to preside at a gathering so important as this. I regret sincerely, however, to say that Mr. Ransdell, who was originally chosen to preside at this meeting, was unable to come owing to duties which he is called upon to perform at this time at Washington and which are possibly much more important than anything which could be taken up on the outside.

Senator Ransdell has always expressed an active interest, not only in the things which concern the development of his own state, but which concern the development of the Southland or the development of the whole United States, and I regret exceedingly that he was not here to address you in person.

This is an important meeting, gentlemen; one that is of great significance-a meeting which we hope will mean something to you and the sections which you represent. This meeting is not called for the purpose of fostering any real estate interest or any specified real estate development, or for the aiding of any men or set of men, but it has been called by sound-thinking men for the purpose

Vast Problem Must Be Solved of bringing attention to these large areas of cut-over lands which exist in the lumber belts of the Southern States, areas of cut-over lands that now approximate something like 40 to 50 million acres in that territory. Therefore, we hope that in your deliberations here, in the papers that will be read before you, in the thoughts that will be expressed, will have your due, careful and earnest consideration, because there is a problem to be solved, a problem the solving of which will mean so much to the development of this section of the country.

Now, gentlemen, I am called upon to act in a sort of dual capacity today-not only called upon to represent Mr. Ransdell as chairman of your meeting, but called upon to express the regret of the Governor of the State of Louisiana that he was not able to be present, being confined to a sick bed at the capital at Baton 
Rouge, and therefore I an going to claim the privilege of the chairman and, without further ceremony, will introduce myself to you as the representative of the Honorable Ruffin G. Pleasant, Governor of the State of Louisiana. (Applause.)

Gentlemen, as the representative of the Governor of Louisiana I wish to say to you that the Governor regrets exceedingly that he was not able, owing to sickness, to be present here today and to welcome this distinguished body of men from these various sections who have come together here to consider problems that mean so much to the State of Louisiana as well as to the other sections. The Governor appreciates fully the significance of this meeting. He recognizes that any plan or set of plans which can be brought about to further the development of these areas of cut-over lands that exist in the State of Louisiana, approximating something like five or five and a half million acres at the present time, will be of great good to this state and the people and that prosperity will follow in the wake of this development; and I want to say to you that it is a question of great importance. There is no more important question which can be taken up at this particular time, for now. at the time of the nation's crisis; now, at the time when we are entering into the world war; now, at the time when we are going to require the efforts of the sound-thinking men to bring about a further development along agricultural lines and along the line of raising foodstuffs generally, and also live stock, this is a live question and a question that concerns us all and we should give it serious deliberation.

Louisiana has something like twenty-nine million acres of land and today there is less than five million acres of that land under cultivation. Louisiana has the greatest body of alluvial lands that exist in the world today, and still there are large tracts of this land which still remain uncultivated. Louisiana has vast prairies which future development would make ideal stock farms. Louisiana has had something like fourteen million acres of timber land, something like nine or ten million acres of pine land, and today there exists in the state over five million acres of cut-over pine land, and the problem is, what are we going to do with it and what are we going to make out of it? About 80 per cent of it, as we see it, would be susceptible for agricultural development.

Louisiana has made a great deal of progress as to demonstrating what can be done with this cut-over land. Situated in some

Lonisiana's $.0,000,000$ icres of $U n-$ developed Cut-Over l. 1 inds
Governor Pleasunt, Louisiana, Sends Greetings 
Big Yields From CutOver Lands

of the parishes of the state, the cut-over lands have become the most valuable lands we have in the state, because, after all, the value of land is based on what it produces in actual revenue. We have cut-over lands in Louisiana that, at a conservative estimate, are yielding in actual revenue per acre, per year, one thousand dollars. We have exceptional cases where this has gone as high as two thousand dollars, but the agriculturists tell us, by their experiments and by the experiments of the Louisiana Department of Agriculture, that these cut-over lands have an actual cash value for the production of hogs of at least $\$ 50$ an acre. Therefore, it seems to me we would not be wasting time if we encourage the exploitation and development of these lands; and I sincerely trust that the deliberations of this body of earnest, sound-thinking men, who have come here to consider this problem, will evolve some scheme and idea where those lands can be brought into early use; and now, gentlemen, again, on behalf of the Governor of the state, I bid you a most hearty welcome to Louisiana. I thank you. (Applause.)

\section{Address of Welcome By Hon. Martin Behrman Mayor of New Orleans}

Mr. Chairman, Ladies and Gentlemen of the Conference:-I do appreciate the importance of this conference. For that reason I have canceled whatever engagements I may have had this morning in order to be with you and personally extend to you a word of welcome for the people of the City of New Orleans.

At this time, in this crisis, it is proper and meet that men like yourselves should come together for the purposes of doing something to encourage the use of these wonderful lands of ours. You know and I know what the cut-over lands of the South in certain sections are producing, but the South will be called upon to do

The South's Duty to the Nation her share now and to do it promptly. We will be called upon to raise the products to feed the Allies as well as ourselves. We will be called upon to furnish the rest of the country-who are not blessed as we are, with the splendid soil we have and the splendid opportunities we have here in the South-we will be compelled to furnish them with the food products they may need. So I say this is an important conference, one that $I$ hope will bring about 
the best results. We have a wonderful soil, and we have a wonderful people, but we have been going along content just to let well enough alone. Everything came easy for us; nature has been very kind to us; anything we put in the ground would grow ; and nothing would better illustrate the feeling of being satisfied to let well enough alone than this: Some years ago, when a company of army engineers were locating the route of the Intercoastal Canal in our state-part of it was completed, but part of it had to be done with the aid of teams-they came to a beautiful section of our state and saw a big family sitting under a great big oak tree; that family had a splendid tract of land, but there was only a small portion of it under cultivation; and someone in the party said, "Why don't you cultivate the rest of this land?" He replied, "What's the use? We have enough." That is the spirit we want to get away from, and now it is not only the spirit of doing things different from the way we used to do them, but the necessity that we must do it, we must use those lands, and we must put them to the uses for which they were intended. It is not only a question of whether we ought to do it or not; it is a duty and it is compulsory.

Speaking of the different arts, I read a few days ago that 'way back in 1859, in a speech to the Agricultural Society of Wisconsin. Abraham Lincoln said: "The most valuable of all arts will be the art of deriving a comfortable subsistence from the smallest area of soil."

We have the soil and the acreage and all the other things. God has blessed us with a splendid climate, and what we may lack in people we can get from immigration. I was one of those who never believed it was necessary to bring them all down into this section of the country. You have the people in this country; they only have to be educated up to an appreciation of the value of those lands, and learn the possibilities of them and see the uses they can Immigration Not Essential. be put to; and then the farmers from the great West and Northwest can come down here and develop these lands with the energy they have shown in their own sections of the country; and then I believe every section and all the lands of the state will be put to use.

Now, my friends, I hope the deliberations of your conference will be entirely successful, and on behalf of the people I want to say it is their earnest desire that they will be, and they bid me say to you that you are most heartily welcome here. I thank you. (Applause.) 


\section{Importance of Agricultural Development to the Cities By Ernest Lee Jahncke President of the New Orleans Association of Commerce}

Gentlemen:-With the same earnestness evinced by our Honorable Mayor, I, also, as President of the New Orleans Association of Commerce, want to welcome you to this conference and to express pleasure at having you come to this city to hear the discussions upon, and endeavor to solve problems so vital to the nation's welfare at this time.

As the head of a civic body organized for the purpose of promoting the industrial and commercial welfare of New Orleans, I realize the importance which the work you gentlemen are undertaking has upon the development of this and other cities of the South. The head of the greatest statistical organization in the country recently said that in 1950 the largest city in the United States would be situated in the South and the chief reason upon

Nation's

Greatest Future City May $\mathrm{Be}$ in South

Co-operation Necessary to Success which he based this prophecy was the potential resources in this territory, which you are now endeavoring to uncover. To release this dormant wealth for the public good will require a great deal of work, not only on the part of the agricultural interests, but in co-operation with the Chambers of Commerce and Boards of Trade, with the transportation lines, the bankers, the merchants, the trade organizations and the colleges and experiment stations. The growth and prosperity of all these factors are interdependent; the losses sustained by one are shared directly or indirectly by the others, and the touch of Fortune is felt by all alike.

If the farmers in a locality have had good crops and are able, with the co-operation of the financial and commercial agencies, to market same profitably the effect is felt all through the district. If, through lack of practical aid being given to the rural communities, or in the absence of such communities there is no effort to develop them, the cities and towns in those sections cease to progress, and if the proper steps are not taken, the retrograde movement begins. 
The days when people have sufficient unto themselves are beginning to fade away, so much so that the whole world is looking to more centralized effort. Whole nations are no longer able to be entirely independent of others, and even now each continent needs the assistance of the rest of the world.

We have been made to recognize in the past two years more than ever before the importance of agriculture to the prosperity of the nation. There is hardly a more important subject today than the national food supply, not only as a factor in our own national life, but in that of other nations. Without the farmer how long could the soldiers maintain thenselves in the fields? There is one little incident in history that impresses me in this connection, and that is the story oft told about Cincinnatus, the patriotic Roman, who left his plow standing and hastened at top speed to help the empire when news of war reached him. If Cincinnatus were a farmer in these times the thing which he would be most likely to do would not be to leave his plow, but he would be encouraged by his government to push the plow more vigorously and where possible add another plow.

The ruralist of today is not the farmer of the days gone by; he does not make his once a week trip to the nearest market to dispose of his product and then bury himself in his farm for the next six days. With the aid of the automobile, good roads and interurban lines, he is now very much a city folk; he visits the city places of amusement, makes his purchases in person at the city stores and invests his money in municipal enterprises. Thus we see that the distinction between urban and rural welfare is being eliminated and that each must work for the benefit of the other.

When commercial bodies commence to take notice of these things and desire to do what is necessary for proper development along these lines, they should make a careful study of the needs and possibilities in their localities, and if all such organizations in the South give attention to the problems presented and threshed out at this conference; I feel certain that great steps will be taken in that direction.

In this connection, it might be advisable to give some statistics regarding the possibilities of the South, the surface of which has thus only been scratched. In 1900, in Alabama, Arkansas, Georgia, Louisiana and Mississippi there were over one hundred and sixty

Nation's Fute

Largely in

Hands of

Farmer

City and

Farm Interdependent 
million acres of land capable of being cultivated, and of which but 24 per cent had been improved. Between 1900 and 1910 nearly six million acres more of improved farm lands were added, making 27 per cent at the latter date. Comparing: progress in these states with that in other states, and making due allowance for increased developments, it is probable that by 1930 at least eighteen million Only 27 Per-acres more of improved lands will be added to the farms in these cent of South's Lands Now Developed five states, or 38 per cent. This is not at all a rash prediction when we note that 34 per cent of the area of Wisconsin was improved farms in 1910, and 49 per cent in New York, notwithstanding the large mountainous area of the latter state. In the prairie states, Illinois has 78 per cent of improved area, and Iowa 83 per cent, which marks the maximum of present development. This will give an idea of what can be done in the South. Wisconsin, which I said has 34 per cent of improved farms in 1910, is the leading dairy state of the Union, yet experts say that the possibilities for profitable dairying in the South are even greater than those in the North.

To realize what the addition of eighteen million acres of improved farm lands would mean to industrial activity in the South we have but to refer to the building statistics. According to census reports, the average investment per acre for buildings in the five beforementioned states was $\$ 8.48$. To preserve this average per acre for buildings, which, by the way, is almost $\$ 5.00$ less than the average in Northern states, farm buildings to the amount of 150 million dollars would be erected, and, using the same census reports, it is estimated that forty million dollars' worth of agricultural implements and machinery would be used. These figures are based upon the assumption that the same methods of farming would be maintained in the South, but if they were brought to the higher planes of the Northern farms these amounts would be greatly increased.

The South's greatest resource today is her yellow pine forests. In the seven leading states producing this species of lumber, over one-quarter of a million people are employed in lumber industries, which means that over one million people are dependent upon this source for a livelihood. Hundreds of towns are built up and maintained mainly because of the sawmill operations in those vicinities. Millions of acres of cut-over lands are left idle after the woodman las passed. These lands have been productive of wealth which has given work to so many people and if they are to be kept as a source of revenue, we must look to the co-operation of all agencies, governmental and private, to do so. 
New Orleans is situated at the very door of this great industry and its effect upon the city's growth has been very marked.

For years we have been benefited by the millions invested in this work and the returns from the product. How are we going to preserve this activity so vital to the welfare of this city and to other Southern cities? The South has not yet reached that stage of a manufacturing locality where capital and labor ending its usefulness in one industry can be converted into another. We must endeavor to take care of this by utilizing the lands that have been cut over; making it possible to create productive farms ihroughout the now barren land. The problems solved at this conference and the work of any organization effected to carry them out are the greatest steps taken to this end and should receive the support of all commercial organizations.

\section{Practical Reforestation}

\section{Paper prepared by Henry S. Graves, Chief Forester, U. S. Forest Service, and read by E. S. Bryant of the U.S. Forest Service, representing Mr. Graves}

The undertaking which you have called this meeting to consider is one of very far reaching public importance; it commands the interest of the whole public and should have its active support. The movement you have initiated is peculiarly significant of a new spirit in the country and it points in the direction of a virtual reconstitution of the inclustrial organization of the country.

Our history' has been largely that of opening up and exploiting virgin resources. In a considerable part of the country our industries might be likened to placer-mining that gathers by rough and ready methods the gold accumulated in the surface wash. In many respects we are only beginning to emerge from conditions of primitive development, so far as botl industrial and political organization is concerned.

Politically we are still a nation of small political units, each preoccupied with its individual problems and each working in large part independently of and often in competition with its

Undertaking Worthy of Active Public Support 
Correlated

Efforts

Needed

II'ar Crisis

Emphasizes

Need of

Nation for

Common Ef-

fort

After Lumbering, What? neighbor. In public works, as, for example, road building and flood control, uncorrelated effort between counties and towns results in failure or in achievement by a very costly route. There is often lack of sympatly and confidence between county and state, or state and federal government, and lack of mutual confidence between counties and between states. So that when the larger unit of government is appealed to for aid in inter-county or inter-state undertakings, localism manifests itself in demands for the lion's share of common funds.

We are only just beginning to feel an economic pressure requiring harmony of purpose and unity of effort in internal affairs; and we are facing in the present international crisis the consciousness of national weakness because of the lack of correlation between our many separate political units. We are also just beginning to appreciate that there is a lack of industrial organization of the country, that public interests and industry have a vital relationship, that the industries of one locality are of inportance to other localities and to the people as a whole.

The very wealth of readily available resources has made it possible for individual undertakings to succeed and localities to prosper. When the cream has been skimmed off, communities discover that they have not been building permanently. The larger public learns that sources of supply are exhausted, and distress is caused by inability to obtain new supplies readily and at reasonable cost. And when there is an unusual stress, such as the present, the nation having the greatest resources of all nations sees local shortages of a great variety of products such as coal, timber, steel and foodstuffs.

The consequences of the local exhaustion of virgin resources are very serious unless there is a replacement by a productive use of the land. In many sections the first industry is lumbering. If the land is rich and tillable agriculture follows with its farm homes, communities, cities and related manufacturing.

In the South you are now facing the problem of progressively diminishing virgin resources, and what you are going to do to sustain and build up local industry. Lumbering has been your foremost industry. Today the South leads in lumber production. In 1880 the South produced about 12 per cent of the nation's lumber cut; in 1914 the proportion of lumber from the South was nearly 50 per cent. All know that the virgin supplies are 
being rapidly depleted and will be largely cut out in a couple of decades.

We have seen the Iake States leading the country in lumber production twenty-five years ago, and now yielding only about 10 per cent of the nation's requirements. What is replacing these industries? In some places agriculture, but over many millions of acres nothing-a vast wilderness, fire swept and barren of useful products, here and there a trace of a former sawmill town, old farms deserted because the local industry with its markets is gone, roads almost impassable because the taxable resources that would keep them up has been destroyed, a virtual depopulation of hundreds of square miles.

Today the great paper mills of the Lake States with millions invested in equipment and water power are embarrassed to secure supplies of wood, and they face the necessity to import wood from a great distance or to abandon their plants. Inquiries have already been made whether material could be secured from the National Forests of the Rocky Mountains to supply paper mills in WVisconsin; and it has always been hard for me to reconcile myself to the importation of wood pulp from Scandinavia to points 1,000 miles in our interior.

For many years the United States has occupied a commanding position in the production of naval stores. I believe that we have been producing about 80 per cent of the world's supply. This country has the best source of supply of the world in respect to species of trees, climate and accessibility-conditions unexcelled anywhere. Yet we are rapidly dissipating this resource, and if we keep on, not only the South, but the country. will lose its place as an important producer of naval stores. We know that we can get turpentine from Western pine. and can by distillation obtain it from Douglas fir and other species, but possibly with less yield and greater cost. The Southeast with its long leaf and slash pine is the logical place for turpentine production. It is important both to the locality and to the nation to have this thirty-five million dollar industry continuer. Is it necessary for the South to lose its place in turpentine production or in lumber production? If they were to be replaced by agriculture, production of cotton, corn and other farm products, and the land now producing trees were turned into productive fields. I should say that there would be no less, but perhaps a gain.

Niaral Storess Industry Endangered
Latie Stutes Huch of Forest Area Left Barren and Unpopulated 
If A Permanent Lumber Supply May Be Assured

Slow Development of Cut-Over Lands

But that is not the case. There is an opportunity for an agricultural development of gigantic proportions, and at the same time a permanent turpentine and lumber industry. Millions of acres of land in the South are unsuited to crop growing, but capable of producing trees of exceptionally rapid growth. Shall we sacrifice tree production on the whole because a part of the land is better suited for crops? Is it not possible to carry on both industries side by side with the land devoted to the purpose for which it naturally is best suited?

Pennsylvania is sometimes held up as an example of a state that originally was a prominent lumber producing center, and in which that industry is now replaced by manufacturing, agriculture and mining that makes it one of our richest commonwealths. It is true that in the broad valleys fields have replaced the forest. It is true that mining and manufacturing places the state in the front ranks of wealth. But it is also true that over great portions of the state the forest has been replaced by a waste of scrub oak and sweet fern, with a scanty population struggling against the most adverse conditions to hold their own. Today the state is trying to reclaim its mountain wastes in order to restore the logical resource of much of the region, the forest, and lay the foundation for future productiveness and industry where the land today is a burden on the public.

What is happening now in the South? Are the logged off lands being settled up, and is lumbering being replaced by agriculture? In general the extension of agriculture over logged off pine lands is exceedingly slow. It is doubtful whether at the present time the movement much more than offsets the abandonment of cleared lands. WVe know, for example, that between 1900 and 1910 there was an actual decrease in improved lands in over 25 per cent of the counties of the pine region. I presume that it is safe to say that the demand for logged off land for agriculture does not exceed 10 per cent of the area cut over each year.

To a limited extent logged off lands are grazed and in places there is some forest growth coming back. Most timber land Fires and owners take the position that forestry is not practical for them, Hogs Retard so that fires continue to run over the lands, preventing in large Reforestation measure a regrowth of trees. In some sections also inregulated running of hogs on the range effectively checks the reproduction of long leaf pine. Tree growth is accidental and such as oc- 
curs is in spite of the forest fires and other adverse agencies. In short, the present resource is not being replaced by any other that will equal it in value. The state is therefore suffering a net loss every year.

The question then arises whether the failure to settle up the logged off lands is a temporary condition, and whether with organized effort settlers cannot be induced to take up the lands much more rapidly in the near future.

The fact that the lands are level or moderately rolling, that an analysis of the soil shows some crop raising possibilities, and that the climate is favorable, has misled many persons regarding the immediate development of these regions. While there is a great deal of land of good quality, we must also recognize the fact that there are in the aggregate immense areas that are too poor ever to be used permanently for crop raising and other areas which can be made productive only by abundant fertilizers and rather intensive methods of farming and which probably will not be profitable to cultivate for a long time. Repeated ground fires are making these lands even poorer, both for possible cultivation and for grazing.

The problem in this region is not only to get the real agricultural lands settled up, but to secure the productive use of the balance. The combined use of the lands not of immeriate agricultural use for grazing and forestry is, in my opinion, the answer to the question.

It happens that in the Gulf States you have conditions for forest production equaled only in portions of the north Pacific region. Your pines grow with very astonishing rapidity, so that in considering returns it is not necessary to think in terms of a century or more, as in certain mountain regions.

Within the regions suited to the growth of slash and long leaf pine we have the possibility of producing turpentine on a very practical basis. Studies by the Forest Service indicate that slash pine in natural stands can be used for turpentine in twenty to thirty years, and is capable of yielding as much as 500 cups per acre. These young stands are boxed now, but so severely treated that they are destroyed in three or four years. Under the French method the trees could be worked for from twenty-five to fifty years. In much of the South the long leaf pine could not be worked for turpentine quite as early, but in each case the pro-

Much of the Land Losin!! In Value
Ten Per Cent Profit Possible in Raising Turpentine Trees 
duction age could be considerably reduced by thinnings such as are made in the Maritime Pine forests of southern France. Here. then, we have a possibility of raising trees for turpentine on a very profitable basis with the naval stores the chief product and the wood a by-product. Estimates by the Forest Service show the possibility of a 10 per cent investment, based on $\$ 5.00$ land. This is pretty good for land that is not suited, at the present time, for agriculture.

In the matter of timber production the South is in an exceptionally favorable position. Examples may be multiplied which demonstrate that young long leaf pine stands are growing at the rate of from 600 to 800 board feet per acre per annum, $J$ and, where properly thinned, would yield more. Loblolly Pine under reasonably favorable conditions grows with equal rapidity. Such growth, of course, occurs only where there is a reasonably good stand of trees.

From the standpoint of the public, production of even 200 feet per acre per annum would be of great value. It would mean a growth over the whole region of over twelve to fifteen billion feet, enough to sustain the turpentine industry and a lumber industry of large proportions in the aggregate for many years. I believe that it is entirely possible to secure this growth, by organized fire protection and by the systematic use of the pine lands for grazing, agriculture and forestry.

One of the things that has been demonstrated by the administration of the National Forests has been the practicability of producing timber and live stock on the same lands. In the West as in the South the forests are chiefly coniferous. For-

Growing Timber and Live Stock on the Same Lands merly these lands were over-grazed and as a result were steadily deteriorating in productiveness of forage, and the forest growth was progressively injured. The system of regulated grazing now in effect has largely restored the forest range, stopped erosion and safeguarded forest production. The same can be done in the South. Unless I am misinformed, the constant abuse of the Southern lands by fire is steadily lowering their value for grazing and for possible later agriculture. Control of fire and regulated grazing would make these lands more productive.

Still another result in the National Forests has been the development of scattered agricultural lands directly due to the public forestry enterprise. The activities connected with the forests, and the stability of grazing on the public forests, are 
bringing in settlers to occupy lands that conld not be developed if these other resources were not being built up at the same time. It would, I believe, work in the same way in the Sonth. Every active step in the way of using the non-agricultural lands for grazing and forestry stimulates the use of agricultural lands and building up of communities. The National Forests are carrying over ten million head of live stock and growing trees at the same time; and the lands suited to farming are being oc-

Grazing and Forestry Stimulate Agriculture cupied by actual settlers, most of whom would not have an outlook for permanence if the old system of forest fires, of exploitation of timber with no regard for restocking, and of unregulated over-grazing of the mountain slopes prevailed.

Granted the trutl of these contentions, how can the results be attained in the South? Unquestionably it will be possible to get private capital interested in handling lands for turpentine production. The profits are certain and the period before actual returns reasonable. But the average timber land owner balks at even a forty-year proposition of tree growing. So far the socalled conservation programs of the lumbermen of this region have wholly left out the continuance of the forest by regrowth. Thus the proposal recently made through the National Chamber of Commerce to urge Congress to permit agreements in restraint. of trade where this would promote conservation of primary natural resources had in view only the saving of waste in exploiting present resources. Forest production by growth was overlooked as impractical.

Personally I do not have much expectation that many private owners of land in the South will individually undertake forestry merely on a showing that these lands are capable of producing thirty to forty thousand feet per acre in forty years. Nor do I believe that they will succeed in colonizing their cutover lands on any large scale under plans now in vogue. Speculative land boosting would react to the injury of the country. Often land may be sold, but not developed. On the other hand. I believe the plan of combining agriculture, grazing and forestry is entirely practical, and can be successfully undertaken through collective effort. The results are so important that I believe that this collective effort should include the public as well as the private owners of the land.

First of all, there has got to be some stability of ownership) of the land and policy of its use. Where non-resident owners
Forestry Not Impractical

Collective Effort Necessary 
State Ownership Would Have Sonte Advantages
Private Owners Must Face the Problem who have bought the land for its timber are simply holding the land until they can sell it at almost any price, but little can be done. If, however, the owners retain the land with a view to its productive use, plans can be put into effect involving the development of the property for the various uses for which its different parts are best suited. Neighboring owners could coordinate their activities of fire protection, grazing administration and forestry, just as the Government does with other owners whose lands are adjacent to and interlocking with the National Forests. Of course, the plan would work out most simply if the state owned all the lands. It would sell the agricultural lands to settlers and for townsites; it would sell timber as we do in the National Forest, retaining title to the land and providing for protection and regrowth; it would lease grazing privileges on the same lands and would provide for miscellaneous special uses of the lands as demands might arise. A great deal of the grazing would ultimately be by the settlers who would build up herds in connection with their farms. The grazing privileges would result in an increasing number of settlers who would combine agriculture and stock raising and thus use land for agriculture that without the grazing would not support a family. Progressively the agricultural land would thus be occupied and the balance put to its best use.

The timber would furnish a stable and permanent industry and contribute also to the increased use of agricultural lands, through the markets for food and hay and the chance for parttime employment connected with its various activities. This is the sort of thing that is actually occurring on an extensive scale where the Government owns the land in the National Forests.

The public does not own the pine lands of the South, and it may not be feasible to acquire them. The question is whether it is possible to secure under private ownership their productive use, even if that is not as complete as if the state owned the lands. The public interests in the right handling of these lands is so great, the public loss from wrong handling so far reaching, that it is only a question of time before the states themselves will enact regulatory and restrictive legislation regarding them if they are allowed to become an unproductive waste. A better plan, in my opinion, is for the public and private agencies to unite forces now and by joint effort work out a method for putting the development of the pine lands on a permanent and stable basis. 
We need in this problem, as in many other matters, not so much regulation by the state as correlated action and joint effort by the public and private agencies, working toward a common purpose. This plan is in successful operation in the West in forest fire protection and in the handling of grazing matters. While conditions are different in the South, the principle is, 1 Preferable to State Regulbelieve, feasible if the land owners are prepared to enter upon a far-reaching plan of land administration.

There would be involved first of all a classification of the land and a survey of the resources, both timber and grazing; then a plan of development, administration, finance and control.

Personally I should like to see a plan worked out for a specified group of holdings, under the direction of a board or committee composed of representatives of the owners and of the public agencies that might be interested, as the county, state and federal government. If such joint enterprises could be undertaken it would turn the course of the use of the pine lands Offers Assistance of Forest Service from a progressive destruction of resources to an upbuilding process. If such constructive enterprise should be initiated you may confidently count on the support of the Forest Service. 


\section{Practical Utilization of Cut- Over Lands}

By Stanley F. Morse

\section{Consulting Agricultural Expert, formerly of the University of Arizona}

Differences in Climate Must Be Considered

Ciut-Over

Land Soils Offer Wide Variety
Gentlemen:-I am going to endeavor, in a very few moments, to outline briefly the possible methods of practical utilization of these cut-over lands. The first thing I want to call your attention to is the fact that the method of utilization should be based on the local conditions. I find, in going over the cutover lands, that there doesn't seem to be enough attention paid to this fact-that there is a great variety in the conditions amongst which these various lands are situated.

For instance, let us take the conditions that will obtain in the different sections where the cut-over lands are located. We find that the first and most vital difference is that of climate. I don't suppose many of you realize there is so much difference, but if you will travel north from New Orleans a hundred miles you will find there is an appreciable difference in the dates of early and late frosts, and in the mildness of the winter.

Let us take simply the mildness of the winter. That makes a great deal of difference from a cattle-raising standpoint, hecause in the milder sections you not only do not need such elaborate shelters, but the feed will remain greener for a longer period. Then, of course, the early and late frosts help to determine the kind of crops you can plant. So the first thing to be considered is the matter of climate, and that is also tempered by the elevation. For instance, you may strike a certain locality which is considerably higher than another, and you will find that the temperature is cooler; and in another place in the same latitude lower down you will find a milder climate.

The second thing is the soil. A great many people seem to think the land of the cut-over section is more or less the same kind of soil. That is a fallacy. As a matter of fact, I have found soils varying in the cut-over district from a heavy clay to a very light sand. That will make a considerable difference as to the 
utilization of those lands. The type of agriculture which you are going to attempt to carry on successfully will be governed to a large extent by the fertility and type of the soil. Of coursc, the heavy types of soil are apt to be poorly lrained and have to be broken up, while the lighter types have not so much of the organic matter in them and are well drained, and in some cases quite leachy.

I haven't the time to go into this matter in detail, but I want to emphasize the fact that in developing the method of utilization of this cut-over land you have to study your soil conditions as well as climatic conditions and then adapt your crops or live stock to these conditions.

The next factor which I would call your attention to, and which is also of considerable importance, is the matter of topography; in other words, what the farmer calls "the lay of the land." We may have flat lands, gently rolling lands and hilly lands. What difference does that make in the utilization of the land from an agricultural standpoint? It makes all the difference in the world. For instance, where the land is level in large areas it is generally recognized that a rather extensive type of agriculture can usually be profitably practised, for the reason that it permits of the use of labor-saving tractor or horse-drawn machinery. If you have land broken up by hills and you attempt to run large tillage implements over it, you will find that your cost of operation is considerably increased. So a vital factor that I would call your attention to is the matter of topography.

I might also point out that where you have rolling or hilly lands you get better drainage; and there is also a tendency for the land to wash, so that if you intend to raise cultivated crops you are going to have to terrace your lands. Such lands would better be kept in sod for pasture or hay.

This would be a better and more natural utilization of the land under local conditions. I emphasize again, then, that the topography of the land is a very vital factor, which will influence the success or failure of the type of agriculture you engage in. I have seen a number of different methods of development tried, and in many of them there seems to have been little attention paid to these factors.

Then comes the fourth factor, of transportation. You hear a great deal of talk about the utilization of cut-over lands for truck raising. If you are forty or fifty miles from a railroad, how

"The La!n of the Land." 
Transportation Facilities Vital Factor in Type of Crops Grown

\section{Cut-Over}

Lands Ideal for Pasturage

Live Stock Farms Must Be of Proper Size will you get your perishable products to the market? That brings up the question of to what extent may we utilize these cut-over lands, far distant from railroads, for the production of more intensive crops? Naturally, the utilization of lands for this purpose is limited.

As to the adapted agricultural products, very briefly, it seems to me that the type of utilization which will be most profitable for these cut-over lands is live stock. In the first place, there are two or three things which lead to that conclusion. The average cut-over land is what might be called of medium to low fertility. The fertility, as a rule, is not high, although I have seen some that were in a very good state of fertility; but the average is rather a low state of fertility. That means that if you try to produce food crops or any other kind you will have to fertilize highly or set aside a period of years during which to build up your soil, and that will increase the cost of producing your crops and is going to make the production of certain crops unprofitable.

In the second place, these lands are cheap. The grasses are fairly good, lespedeza is coming in, and the pasture possibilities of these lands seem to be almost unlimited; and on the rolling lands the sod tends to hold the soil. You have a natural utilization there by nature's work, and you should utilize that pasture in some way.

I have recently come from the West. and we find that hundreds of thousands of cattle are being raised on cheap pasture - what is known as the range system; and the only reason we can do that is because we have an abundance of this cheap pasture and we can afford to let our cows graze over this pasture and virtually take care of themselves and raise their calves; and then these animals, when they are large enough, are shipped to the richer lands for fattening for the market. That seems to be the most common and natural utilization of this cut-over land. Another thing: The need for more beef cattle is an increasing one, and if these lands are available in large areas, and are cheap and adapted to pasture crops, that should encourage the influx of large cattle owners who can operate on a big scale, and they can produce feeders more economically than some of the small men. That doesn't mean there is no place for the smaller live stock farmer, because I believe there is. One point there: When you try to induce the farmer to practice live stock raising, you should 
not sell him a farm too small. I notice some of the cut-over land owners are cutting their lands up in parcels which, on the very face of the thing, are too small to enable the man to make a decent living. The amount of income which a live stock farmer can secure from an acre is limited by the number of cattle it will support, and if you limit him to a certain number of acres his aggregate income will not be sufficient to make him a decent living, and then he will get discouraged. In the West and other parts of the country we have found that you must have a size of farm which is sufficient to give the farmer an aggregate income which will enable him to operate profitably. So there is a place for both the large and the medium-sized farmer.

Not only cattle, but sheep, can be grown here economically. and on some of the cut-over lands I have seen hogs which are as fat as you could desire, in the middle of January-simply rolling fat; and these hogs did not have the advantage of winter Sheep Raising and Forage Crop Possibilgreen crops such as oats or crimson clover.

The other utilization will be by means of crops. What can we raise? We cannot raise, I believe, gentlemen, what might be known as the foodstuff crops. If we attempt to raise wheat and barley and products of that sort, which can be more economically produced on better or richer lands elsewhere, we will make a mistake: but if we raise forage crops which are naturally adapted to these cut-over lands, that is more apt to give you an income. You can either feed them to the cattle or sell them, and you have a ready money crop. Among those I might mention the cow pea, lespedeza and various other legumes and grasses which are already adapted for producing feed crops to sell as hay or feed to your stock. If you desire to raise grain crops, there are only two crops you can give consideration tooats and corn; also, maybe some legumes or cow pea seed. Oats and corn will probably be a fairly profitable crop; oats is not very profitable under the best of conditions, but it is probably better than corn. In looking over the cut-over lands, I find corn is a very light producer. IVe find there is a range of from fifteen to thirty bushels per acre. and the lower yields secm to be more common. Since most of the cut-over lands are hilly, or of a broken character, it is questionable how economical it will be to attempt to cultivate corn on lands of that character. This same statement applies to cotton, which is a fairly profitable money crop under favorable conditions. 
Three Best Menns of I'tilization
Success

Assured If Proper Methods Followed

One more thing: I have mentioned forage crops and grain crops, and have forgotten to make any mention of truck products-the money crops. In certain localities a valuable utilization of the lands may be made through the growing of vegetables and fruits. To a limited extent, and along the lines of transportation, there is no question but that, with the aid of fertilizers, we may be able to raise adapted crops of vegetables and fruits; but we must not get away from the lines of transportation. Therefore, there are three main lines of utilization:

First, cattle raising, which is the largest and will be the best method of utilization to start with; it will be most profitable and, to a large degree, the tendency will be to run these cattle on a large scale for the production of feeders for the market.

Second, moderate-sized live stock farming will have a limited application, where the farm is not of too small a size, and there is carried on a diversified sort of farming with emphasis on cattle. hogs, sheep and poultry.

Third, we can raise forage crops, for the market and for live stock feeding, and there will be the limited production of certain grain and seed crops; and then we shall have the more intensive money crops, such as vegetables and fruits, in limited adapted areas close to transportation.

That, gentlemen, in a very brief way, is an outline of the utilization of these lands; and I want to emphasize once more the necessity of thoroughly analyzing your local conditions before you attempt to start farming or colonizing operations. If I had time I should like to talk to you more about these things. but the important thing for you people to do, before you attempt to do anything with certain lands, is to have your conditions thoroughly analyzed and have a plan of farming utilization carefully worked out in advance which has a chance for success in it, rather than one which has a chance for failure. And in selling your land to colonists be sure that for the type of farming you are advocating you have adopted the proper area. Before you get through you will agree with me that you must have farms of the proper size, according to the type of farming your farmers will engage in; and you should see that every assistance is given your farmers to follow out the type of farming chosen as being best adapted to your conditions. (Applause.) 


\section{Agriculture from a National Standpoint}

\section{By Hon. Carl Vrooman}

\section{Assistant Secretary, United States Department of Agriculture}

I shall talk to you in a sketchy, general sort of way about the fundamental policies involved in the consideration of the problems up for discussion at this Conference. IVe have, in the region under consideration-according to data I have brought from Washington-about $76,000,000$ acres of cut-over land on which there is more or less second growth, and about $15,000,000$ acres on which there is no second growth-on which nothing is being produced.

The problem is, what are we going to do with these lands? It is a large subject, and you have wisely cut it up into subdivisions and assigned experts to speak on each topic involved. I shall merely make a brief, general survey of the question as a whole. The Department of Agriculture would like to encourage the development for agricultural purposes of all this area which is adapted to agricultural purposes. We do not know how much of it is adapted to agricultural purposes, and you do not know; and, therefore, the first and most important step that I can suggest is to have a survey made-such as we make in the national forests-to ascertain which of these lands are suitable for agricultural development and which for other kinds of First I'ork Should Be Land Survey development. Those suitable for agricultural development should then be surveyed with regard to marketing conditions. with regard to labor supply, with regard to the financing of such agricultural development and with regard to every other conceivable problem involved in developing these lands for agricultural purposes. If you proceed to act before you do this, you are riding to a fall, you are running into difficulty and you are going in for a proposition which is only half digested. Therefore, the first step is to make a definite survey of the situation to determine what proportion of these lands are good for agricultural purposes, and what other parts are adapted to stock- 
Vuried Adaptability of Cut-Over Lands

Forest Fire Problem Must Be Solved

Experinent Stations Needed raising purposes. A good deal of this land would be adapted to raising sheep, cattle and hogs, which would not be at all adapted to raising cotton, corn, sugar cane or soy beans, or any of the other grain crops. The rest of the land, which is neither adapted to agriculture in the shape of crops or agriculture in the shape of live stock development, should then be set aside as a permanent forest area and a permanent forestry policy worked out through the co-operation of the Federal Department of Agriculture, or the State Forestry Service, and the owners of the land.

Perhaps the greatest single obstacle to a proper development of any of these lines of activity-agriculture, live stock or forestry-is the forest fire: the forest fire not only destroys a lot of forest trees, but it destroys the humus in the soil and the plant life on which the live stock subsist. Until you have worked out a policy which will enable us, unitedly, to solve the problem of forest fires, you have not taken your first step in the development of the cut-over areas of this or any other region. That is a problem that will need the united attack of the Federal Government, the state government and the private owners of these lands. When once you solve this problem and make your surveys, then we are ready to get to work on the subdivisions of the problem. Then we should have established, in all the different sections where these lands are located, experiment stations where we can experiment on solutions for all the problems connected with the agricultural and live stock industries in these regions. At the present time there is a good deal that you do not know, that the state bodies do not know, and that nobody knows. with regard to these problems. We have not yet worked out all the problems connected with the matter of grasses on which to raise the live stock. We have not worked out the problems connected with the proper crops to be grown to best advantage on those parts of these lands which are agricultural in their possibilities. We have not yet worked on these problems sufficiently to know what method of reforestation to adopt. If you were to take this matter up with our Congressmen and Senators, the United States Government undoubtedly would be willing to establish experiment stations in the different sections of the South where all these problems could be worked out until a proper solution for them was found.

Now, in looking at this problem the fundamental principle involved is an old one, and an old one that is today receiving a 
good deal more emphasis than it ever received in the past. In the past, the business men and the Government did not always understand each other. Business men felt that the Government very often was making business activity on their part unnecessarily difficult. The Federal Government, on the other hand. felt that it was only meeting certain problems which had to be grappled with in order to protect the innocent investor. But we have, during the past year or two-and today it is more evident than ever-discovered that the Government and the business men of this country are able to get together and understand each other. (Applause.) The Government is asking the business men to put their cards on the table face up, and on that basis we are getting together for a great constructive effort to build up the agricultural, mineral and industrial resources of this country

Gentlemen, this country has a greater future before it than any of us realize. I suppose the publicity men working on these problems think that they are able to paint, in as roseate colors as the facts will warrant, the agricultural possibilities of this region; but allow me to say to you that no publicity man has yet dreamed of the extent of the agricultural, live stock and forestry possibilities of this great region. We have only just scratched the surface of our national resources: and if we will all pull together, each willing to give a square deal to every legitimate interest involved, these resources can be developed, step by step, until we astonish ourselves by the riches that will be the outcome of our united efforts.

All this was true about two weeks ago. Since then something has happened which has changed very materially the psychology of the American people. WVe are now in a state of war. Everything we could have said ten days ago about this problem we can now say with a thousand per cent of added emphasis. The time has now come for America to make the most of her resources of men, of land, of capital. and of patriotism; if there ever was a time when we should all put our cards and chips on the table and see what we can all do with everything we have, in order to strengthen our nation in this international crisis, this is the hour. (Applause.)

I don't know how much of this cut-over land is adapted to immediate use for agricultural or live stock purposes. We hope

Cut-Over

Land Possibilities Undreamed of
Business Men and Government Gelting Together 
War's Demands Upon the Southland

the war is going to be a short one; but nobody knows. It may drag along for years. Therefore, let us have two programsone, our immediate and emergency program, what we can do this week, this month, this year; and the other a permanent program of national development that will go steadily ahead during all the years to come. I left Washington ten days ago: stopping at Atlanta, Memphis, Little Rock, Shreveport, and today at New Orleans. I have been talking to the people at each of these places about agricultural preparedness, or about food preparedness. I have told the people of the South that the Federal Government is expecting the South this year to do something very novel to the South. It means a great change in the methods of the South. The Federal Government is expecting the South this year to feed herself, and for two reasons: First of all, because if the South does not feed herself the South will go hungry before the year is out. We are not asking very much of the South. We would have a perfect right to ask the South not only to. feed herself, but to contribute her quota toward feeding the soldiers in the field, and also toward feeding our Allies in the trenches of Europe; but we are not asking that: we are not asking the maximum-we are asking the minimum: and we confidently expect the South to respond in full measure to what we ask of her.

When the war was started in Europe most of the countries there thought war was conducted by armies, and that all they had to do to win was to get a lot of men together, train them to shoot and send them to the trenches. England was the slowest. but finally she got together the cream of her young manhood. the most self-sacrificing, the most patriotic, the best men of

England's Early Mistakes England, and they went over to France and Flanders and were mowed down as with a scythe, because England forgot that men can't fight successfully against superior armament, that courage does not take the place of cannon; and so, for month after month. the English soldiers stayed in the trenches and were shot to pieces because Germany had cannon which shot two or three miles farther than theirs did. Then England set to work to get guns, and she found she had pounds of powder where she ought to have had tons. She then set to work and created munition factories on such a scale that today they manufacture more arms and munitions in a day than they used to manufacture in a year. Then they found something else was wrong. The 
working men began to strike all over England. The working men said the capitalists were making big war profits and yet their wages had not been increased, and they struck; and Lloyd George exhorted them and begged them to return to their work from patriotic motives, and they said, "We are perfectly willing to work, but we have to have a square deal: if our masters make huge war profits, then our wages must go up." They would not budge an inch. Finally, the workingmen sent word to the Prime Minister and said: "WVe have a proposition; our masters say we are disloyal, we are slackers and shirkers; we will find out who is the slacker and the shirker: now we will not only work for low wages, but for no wages at all, on one conditionthat the capitalists put their plants and coal mines and railroads at the disposition of the Government as we offer to do our labor, without remuneration." Then the Government called together the capitalists and the workingmen and the Government officials and had a conference; and after a day or two they worked out a plan which guaranteed to capitalists a reasonable profit on their investment and no more, and to workingmen a reasonable wage that would take care of them, even with the prices of food as high as they were, and no more: and on this basis they harnessed all the industrial, agricultural and financial strength of England in the great war, and since that day you have seen England leaping forward like a powerful automobile that has been thrown into high-the change was magical, because from that moment every man, woman and child in Great Britain was working with one purpose only-to advance the cause of their common country. They found that no nation is prepared which does not take justice out of the Bible and out of the skies and out of the hearts of jurists and judges and prophets and bring it down to earth and write it into the laws and institutions of men. (Applause.) And after they had done all that, they found there was still something lacking. They found what Germany had found--and France, and Italy, and even Russia-that after all, an army travels on its belly; that this is a war not between armies but between nations and combinations of nations, and every man, woman and child is doing his bit to help his country. With thirty million people slowly starving in Germany, and every other country in Europe being put on war rations, they found that the war is going to be determined not by the nation with the greatest number of men in the

Victory or Defeat Depends on Food Supplies 
trenches and the greatest quantities of munitions and of financial resources available, but by the combination of nations that is able to feed itself the longest. Just at this juncture we got into the war. We have not enough soldiers to count materially. Our national army and our militia will not be large enough for a long time to turn the tide of battle on any one of half a dozen battle fronts. You will remember that when Rumania went into the war she had 750,000 soldiers, but instead of helping her allies her entrance strengthened her opponents. It is millions of men that count.

We will probably send a division over there on the firing line in France just to show that we are present in the flesh as well as in the spirit, just to plant the Stars and Stripes beside the flags of our Allies: just to show that this country has not forgotten the time when Lafayette and Rochambeau came to America to help us (applause); that will be done largely for its

Food and More Food the Cry from Abroad

The South's Duty to the Nation moral effect. The chief things we can do during the next six months will be to finance and feed the troops of the Allies. We have untold wealth. This country is wealthier than all the combined nations on the continent of Europe. So we can finance our Allies for years to come. But that is not the most immediate need. They now need food, more food and still more food, because every country in Europe has been tightening its belt now for some time; and if the submarine warfare had succeeded England would have been brought to her knees within three months.

The South produces much food, but she imports from the North and West nearly half a billion dollars worth of food and foodstuffs every year in excess of the fruits, vegetables, cotton seed products, etc., which she exports to the North. When we ask you to produce your own food and feed yourself we are only asking you to release that much food and foodstuffs with which to feed our soldiers in the field and our Allies in the trenches. Is the South going to respond to this call? If she doesn't, it is the first call of duty the South ever ignored. (Applause.)

Now that means individual sacrifice. This means that every man, woman and child in the South, without a single exception. has a duty to perform; the children to put in gardens-I don't mean flower gardens, I mean vegetable gardens that will produce food for you during the summer months and enable you to can and dry and put aside food for the winter months. If you 
haven't a garden larger than this platform-it will be valuable not only for the food it will produce but for what it typifies. This flag that I wear on my breast is not big, but it represents everything dearest in life to every man, woman and child under its folds, and when you have put in one little bit of a garden, it stands as the symbol of the fact that you stand ready to do your bit for your country in this great national crisis.

And then the planters and farmers of the South; some of them have gone cotton crazy; because they are getting 22 cents a pound for cotton they can only see cotton. Up in Kentucky and Virginia and other states they are raising tobacco. It may be all right to chew tohacco, but it isn't going to feed you if you have to chew tobacco and spit cotton in the wintertime. And then our transportation systems-they already have been repeatedly congested in times of peace : and during the coming months they will be weighed down with an ever increasing military responsibility. If they are congested, you can't get food through from the North; and then, if the South has failed to raise her own foodstuffs, she will go hungry. So, if there are any cotton planters here today, or if you know any cotton planters, take this message to them from their Government: Any man who is a loyal American citizen is going to do his share toward raising the food crops of his region during the next season, and any man not ready to do that is not worthy to be protected by the flag of our common country. (Applause.) IVe are sending our boys to the front. They are going up there, perhaps, to be shot to pieces. We are here urging them to be brave and patriotic, and yet some of us may lag behind and fail to do the little thing we are asked to do-to make the small sacrifice we are asked to make. I know it is not easy to take a lot of tenants trained to raise cotton and have them raise corn, or soy beans, or sweet potatoes. I am a landlord myself. But this is not a Sunday-school picnic. This is war; and we are not asking you alone to do these things-we are asking every American citizen to take up the most difficult task and do it gladly for his country. If we will do that, if we will get that spirit into the emergency work of the next few months, then this larger, more permanent work of development of agricultural, live stock and forestry resources of the South in due time will go forward with giant strides. We need the right spirit in this work. If everybody becomes imbued with that spirit then the future development of the South's resources will be magical.

"South Must

Raise Her

Oivn Food or

Go Hungry"

"Irar No Sun-

day-School

Picnic" 
There are a great many other things that may be said along these same lines, but there are a number of specialists to speak to you this afternoon on these other topics, and therefore I will simply thank you for your attention, and wish you success in your great constructive and patriotic task. (Prolonged applause.)

\section{The Cut-Over Land Owner's Responsibility-His Opportunity

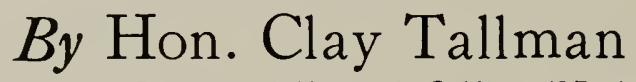

Commissioner, General Land Office United States Department of the Interior

I want to say first that I am very appreciative of the opportunity to come here and contribute a little, if I can, to the development of a national resource, particularly a basic resource like the land, to see if we cannot find a way to make it produce a little more and add something to the upbuilding of the nation.

At the outset, I should say that so far as the public land in the South is concerned, for the purpose of this discussion, it is altogether negligible. The problems we are working on every day concern the lands of the WVestern states, where the great bulk of the remaining public lands are; there we are working out South's Prob- problems and overcoming obstacles not altogether unlike those lems Not Un- you have here, and problems in which, I believe, the general like Those of the West principles-the controlling principles-are very much the same. I feel in a way, so far as I am personally concerned, as if this program is a little bit wrong end to; not that $I$ want to be critical, but just because, in attacking a land problem of this sort, when we take it up in the Western states, we first like to learn as much as we can about the subject; we want to know that in as much detail as possible; and I can only wish that before I came on this program there had been some speakers -as I understand there will be-who had already given us the facts more in detail before we take up the problem with a view to its solution. 
I might say further that I don't want to appear presumptuous. I realize that the sort of problems we are working on are in a different part of the country, where climate, topography, soil conditions and producing conditions are very much different. The people, it has been my experience, are just about the same all over these United States; and they are just about equally progressive in one place as another; and they are equally patriotic, and equally anxious to respond to an appeal such as Mr. Vrooman made here today.

Moreover, so far as the West is concerned, there is no spirit of adverse competition: they want you to do the very best you can here; they want you here in this Southern country to make the best and most of these resources you have; we feel you want us in the West to do likewise, because we know, even from a selfish standpoint, that the more you can raise the more money you can make, and the more people you have making a good living, the more of our product you will be able to buy, and the better we do the more of your products we will be able to buy; the time is long since past when there is any necessity for a spirit of destructive competition as between different parts of this country. I talked to a man in Virginia the other day who is very familiar with the growth and development of that state, and he told me, among other things, that there were thousands of acres of formerly cultivated lands in Virginia that had been permitted to grow to trees, and I said to him, "Why was that?" He said, "After the war of the States there was the great Middle West; and we couldn't compete with the country out there where they had unlimited cheap and fertile lands." Those conditions have passed, as I will attempt to show you.

Now, speaking in a general way, it would seem to me that one of the first questions that presents itself is whether or not there is anything in this proposition we are talking about; whether our efforts must result in failure, as regards this tract of seventy million acres now lying idle; are we dreaming about an impossible thing, or have we a practical problem on which we have a fair chance of success? To me, with the experience I have had in recent years, it seems very strange, it seems almost incomprehensible, to think of seventy million acres of land that will raise anything at all, lying idle, and not being made to produce the most and best it can. 
My home state-Nevada-is probably as unlike conditions that exist here in point of climate, products and general conditions that we have to deal with as regards crop production, as any other part of the United States. I have traveled all over that vast area, and if there is any place in that state, in the most remote place, way off in a canyon, 50 or 100 miles from a railroad, where there is a little spring that will produce an inch of water that somebody has not got, and that somebody is not using and making the most of. I don't know the place, and I don't know anybody else who does. So I say, it is strange to me, it is difficult to understand, how there can be great areas of productive land here that are not being used.

Now, as a preliminary, sometimes it is desirable, in grappling a big problem like this, to get a sort of comprehensive view of the land conditions throughout the nation as a whole, to sort of get a line on the trend of the times, as it were-ask ourselves the question, where do we stand in this nation as a whole on this question? What is its present status? Perhaps a reference, for a minute or two, to the history of the public lands of the United States would not be amiss.

In the early days of this government. Congress looked upon the land as a resource merely to pay debts with, merely to get money out of; and consequently we find that the public lands were disposed of almost exclusively, until the year 1841, on an essentially cash sale system; millions of acres were disposed of to pay debts. Consequently, the government offered the public lands at public auction, and if they were not sold at public sales, they were sold at private sale and anybody could buy all he could pay for; and so we disposed of a great area in that way. The government got a comparatively small amount of money out of it, and there was an era of much speculation and comparatively little development; the poor man with only his hands didn't have a chance. They never asked the purchaser what he was going to do with the land-whether he would cultivate it or what he intended to do with it.

The First Preemption Latw
That system went on until 1841, and then public thought began to change and we had the first preemption law, a little modification of the cash sale, whereby the government said, "We will sell this land to you, and if you will live on it and make your residence on it, you will have a preference right for a limited time in which to buy it." It was a modification of 
the cash sale, whereby a man could get a preference right by settlement. Time went on, and in the year 1862, in the midst of the war, Congress woke up to the proposition that the mere money we were getting out of these public lands was the least consideration; that the matter of cultivation, development and homebuilding was the great big consideration that we should look to: and from 1862 on, you will notice, in all the land laws, all the acts of Congress-that the controlling and main thought has been, how can we dispose of these lands so as to produce the most homes and the greatest development and use.

And so there was never any one act of Congress which so well laid the foundation for the development of the Middle West and the Far West as the Homestead law. We had disposed of, roughly, under the old system, of from 80 to 100 million acres. Under the Homestead law we have disposed of 150 million acres; and under the Commuted Honestead law, whereby by a shorter residence and a cash payment title could be secured to the land, we disposed of 50 million acres more. The operation of that legislation has swept from the Mississippi west to the Pacific ocean, and no single act of Congress has ever been more conducive to the upbuilding of a great empire than that legislation.

The Homestead law meant homes, cultivation and crop raising. Then Congress went on and saw the transportation problem, and said, we must get railroads to this country in order to get the homesteaders there. So we find Congress making great railroad grants to induce the building of railroads. Probably nothing in the way of land legislation has ever been the subject of more controversy and argument, one way or the other, than this railroad grant proposition. Congress has given away, as donations to railroads, probably 160 million acres. Texas gave away 25 million acres more. One thing certain the railroads did conduce very much to the upbuilding of the country. Whether they would have come eventually without the grants, or if so, whether they would have come soon enough, is a mere matter of speculation. Two years ago, when the question of development in Alaska was up. Congress said, we will not give away half of that territory to get railroads; we will keep the land and give it to settlers and build the railroad with government money, carrying that controlling principle still further, making it easier and more attractive and desirable for

Homestead Act Finally Solves Problemi

The Government and Western Railroad Building 
the settlers to make homes; knowing that the more developed farms, the more resources there are in the country, the better we can always secure the necessary revenues to support the government.

Therefore, we have our public land history divided into two periods I have sketched-first, the money getting period; next, the development period. A few years ago there came in still another period. We might call it the conservation or reservation period. Nobody can tell exactly when it started, but it nevertheless did start. Nobody can state, in a sentence, what the controlling principle of this period is, but, in a general way. this last period revolves around this thought: that we have been lax in the enforcement of many of our land laws; that we have not always looked carefully to the best use of all these resources;

Money Getting vs. Development

The Age of Co-operation that we have permitted our land laws in many respects to be abused; that we have permitted certain people and interests to gain a monopoly of this thing or that thing; and so we had various changes in the matter of public policy. We have, through the West, probably 150 million acres that have been put into forest reserves. We have the Government taking up and spending money for reclamation. We have a price put on our coal lands above the minimum: we have the old system which operated to lock up the coal of Alaska, replaced by a complete leasing system; we have a price put on the timber lands above the minimum, the idea being to make the land free and easy to get always for the man who will develop and use it to the best advantage; but if it is a straight out-and-out business proposition, and does not involve a home building principle, then he should pay what it is worth.

I think we are gradually growing into a fourth period. I can see it coming in many ways. Some aspects of it were described by Secretary Vrooman this afternoon. It is a period of co-operative development among all the interests involved. It is the period we are starting in on now, where private owners, the states and the Federal government will pull together more than they have ever done before in the development of these resources. And never before in our country's history was each man's private business so much everybody's business as it is now. For instance, we give a charter to a street railroad company to use the streets, and we impose upon the grantee of that right various duties and obligations. We say it is a common carrier. Now 
the tendency is to go further and further with this. The tendency is for the public to have an interest in everything going on all over this country, whether commonly called private or public. For instance, the public will say you have 70 million acres of good land lying idle here; you won't be permitted to leave that land lying idle in the United States when we need it to produce food for all of us, particularly at a time when the perpetuation of our very national existence may depend on our ability to feed ourselves and our allies.

Now, what is the purpose of all this talk about what happened fifty years ago, forty years ago and now? I simply want to develop this proposition, gentlemen: that the time has come when every acre of land that will produce anything at all has some value and should be put to use, that the time is past when fertile lands can be had in the great IVest for the taking; the great bulk of those lands are all taken and yet farm products continued to rise in price even before the war. If these seventy million idle acres can produce anything, the trend of development and increased production is bound to swing back to the South and East. Take the cattle business as an illustration. Out in Arizona or New Mexico, where it takes forty acres to keep a cow, men are very freely paying $\$ 1.25$ to $\$ 5.00$ an acre for the land, and they are glad to get it. We sold last year 44,000 acres of land in an Indian Reservation in California at public auction. Anybody could buy all he wanted. It was picked-over land. The Indians had been allotted the best of it, and the homesteaders had taken what they wanted, and this was the tail end. It was appraised at $\$ 56,000$, and we sold it for $\$ 119,000$. Last summer we opened the Colville Indian Reservation in Washington, of about 400,000 acres. That was also remaining land-after the Indians had been allotted the best lands. It was very rough and much of it very dry. We held registrations out there for that land, and we had 90,000 applications to register for 3,000 farms. In Dakota a year and a half ago we had 110,000 acres on the Standing Rock Indian Reservation that was appraised at from $\$ 2.50$ to $\$ 8.00$ an acre, subject to the Homestead law. A man could get only so much of it ; he had to homestead it and pay the price, too. We had 30,000 applications for that land, and they took every acre of it. This spring, just before I came down, I signed instructions for some land we appraised two years ago to be appraised at $\$ 2.00$ more

All Land Has a Value 
$\$ 120,000,000$ Spent to Reclaim Arid Lands an acre, just indicating how these things are going on. In northern Montana we have an Indian reservation, known as Fort Peck, and we opened there three years ago a million acres. That had been picked over and the best allotted to the Indians. These lands were appraised at $\$ 2.00$ to $\$ 7.00$ per acre, and we opened them to homestead entry with the appraised price in addition. At that time there were other lands available, and only 27,000 acres were taken up the first year; but the next year, 1915, 71,000 acres were taken; and last year 198,000 acres were taken up. So that the price didn't trouble them. The demand for land on which they can raise something, on which they can make a living in this country, is pressing and urgent. Just one other word with respect to Fort Peck. A large part of that land was classified as coal, and a lot of fellows wanted that land so badly they paid for coal filings on it at $\$ 10$ and $\$ 20$ an acre.

Now, the United States Reclamation Service is another instance of this new era of interrelation between public and private business. The government has now expended probably 120 million dollars in building reclamation projects for arid lands. The cost of reclamation is spread over the land reclaimed. The people buy the water rights, and they must pay annual installments, under a recent law, covering a period of twenty years, for the total cost. What is that cost? All throughout the Western states you will find people willingly and gladly paying anywhere from $\$ 30$ to $\$ 1 C 0$ an acre just for the water alone, to say nothing of the cost of reclaiming the land; and leveling it and getting it ready for crops which may run up to $\$ 50$ an acre more.

I am saying these things to you just to point out a little of what is going on in different parts of the country, just to show the demand for farm land under conditions such that a poor man can work out a home.

It was mentioned by a gentleman here today that if you don't give a man enough land to make a living on, he is going to make a failure. Congress saw that proposition. Back in 1909 Congress saw that there were large areas in the Western country now known as the so-called dry-farming region. It has been ascertained that there are great areas in Montana, Washington, Idaho and Colorado where crops, particularly grain crops, can be raised successfully, where they couldn't raise anything and didn't raise anything twenty years ago; the idea is to crop the land alternate years so as to put two years' moisture 
into one year's crop. Congress said this is extensive farming instead of intensive. To enable these men to make a go of it we must give them more land. Consequently, they gave us the Enlarged Homestead act, giving 320 instead of 160 acres of desert land. Millions of acres have been taken up under that act. You go out on the Great Northern across Montana, or on the Northern Pacific, or on the Oregon Short Line up through southern Idaho, and you will find thousands of acres there today covered with wheat crops, and threshing machines and self-binders, and little towns and elevators. They are making land which was only worth 5 cents an acre per year as a grazing proposition bring in from $\$ 5$ to $\$ 10$ an acre or more per year. Later on Congress said, this dry farming land is about all gone; all that we have left is rough land; much of it stands straight up. Here is a grazing proposition, that land cannot grow crops. Consequently, in December last. another homestead law was passed known as the Grazing Homestead law, giving the entryman 640 acres of designated grazing land, and since December 29,1916 , there have been 45,000 applications covering 18 million acres of that land. I call your attention to this as showing how the people out West are now going after the grazing proposition where there is a chance for a poor man to get a little ranch of his own.

In this connection it should be remembered that the Western open range is carrying every head of stock it is capable of carrying.

Now, doesn't it stand to reason, if we have any land at all left back here in the South, say 70 million acres, or any other number of acres, it is up to you to get busy? Won't it raise something? I don't know how good it is. It may be half swamp, or very low grade, or sandy, but it cannot be any less productive per acre than millions of acres of land in the West out of which tremendous amounts of money are being realized today. I think that if you will take a broad comprehensive view of the land situation of the country you will come to the conclusion that there is no question of doubt that you can successfully compete on this land with the rest of the country; in fact the matter of food production can hardly be said to be longer in the competitive stage; it is rather a question of getting enough.

While in the new development of the raw land it is always best to have cattle and sheep first, I want to say to you that

South Offers Only Cheap Lands Now Left in Country 
Small Farms Best Where Practicable

Little of Western Cow Country Left

wherever anybody can make a decent living, the proper and desirable thing to do is to get people on your land and cut it up into small farms, as many as you can, making self-sustaining and self-owned homes. (Applause.)

We have had a great fight during the last few months between the stockmen and the homesteaders; between those who were for and against the 640 acre grazing homestead law. The cattle men, almost to a unit, opposed it. But the other fellow, who stood for the homestead law, and who proved to be in the majority, contended that whenever we have been able to get people on the land we have gotten more cattle from it than before, and a lot more things besides, and the settlers have made a living and built towns and schools.

Those of you who have been to Colorado know that across that great eastern portion, for many miles back of the Kansas line, is a great area of rolling plains. Twenty years ago, when I used to go across there, it was nothing but a cow country. One would see scarcely a habitation or town. You go across there now and you will find that as a result of this 320 -acre homestead law that whole country is settled, and that country is producing more meat than it ever did before.

I was talking to a Congressman who told me of a valley which a cattle company had completely controlled for years, and when the 320-acre homestead law came in it drove the cattle company out, and now that valley is producing much more cattle than the cattle company produced, and crops of grain besides.

Now, my friends, we have heard considerable here today about various settlement and colonization schemes; while I agree with much that has been said, I want to say as a general thought that if you will demonstrate the possibilities of these lands and show their usefulness and practicability for home building purposes under conditions such that a man can bring up and educate his children under modern conditions, and you will sell the lands at prices and on terms such that an industrious man can pay out, you will not have to resort to any colonization schemes: you can't keep the settlers out.

Now, the chief obstacle in the way, invariably in the West, is the speculator. Invariably he wants to get in between the large land proposition and the man who ultimately cultivates 
it, and drag down all the profit. I want to say that on this $70,000,000$ acres, or any part of it, if you are taking a broadminded, patriotic view of the situation and not a very narrow or short-sighted one, don't put any proposition up to the settler that you are not morally certain he can make a success of if he will work; because his failure is ultimately bound to be the failure of the community and the state.

Now, in closing, I am going to venture a suggestion. This is private land, for the most part. I expect it is largely owned by the timber companies who cut it off. What are you going to do with it? It was said that if it was Government land the Government could handle it like the forest reserves are handled. As I said, this is private land. You can do more with private land than with Government land, because you are free to do with it just exactly as you please, not hindered by law, or supervisory authority. It seems to me that if I were the owner of any considerable block of this land I would first have it very carefully cruised and examined by the best expert I could get; I would have him go over this land with a fine tooth comb for the purpose of determining as nearly as possible just exactly what the land is best adapted to and what it needs in the way of improvement or building up. I would then, with the advice of experts, lay out a plan of procedure and then go to work, on a smail scale at first, to demonstrate fully and conclusively just what could be done with the land. When you are successful in this demonstration then you have reached a point where you can offer some of this land to the public. Wherever possible the sale should be made direct to the settler without any intervening selling agency and consequent added expense. The sale should be at rock bottom prices, on easy terms, with little to pay to begin with, except to demonstrate good faith, the balance being extended over as long a time as possible, on as low a rate of interest as is consistent with good business, and the sale should be on condition that the buyer will reclaim and cultivate or otherwise make good use of the land. You should sell him just as much as he will reclaim, cultivate and use, and not more. Effort should be made to sell adjoining and contiguous lands to other settlers to the end that a neighborly community may be established which will thereby be able to build up its towns, schools and marketing facilities by joint effort. Every reasonable assistance should be given the good faith

Suggestions for Cut-Over Land Owners
Conservative Development Methods Best 
settler to help him get started. This matter of building up an agreeable community life is by no means the least important in this connection. In this manner I believe you will be able in the long run not only to realize a fair price for the land, but you would be contributing a great thing to the upbuilding of the state and the United States.

Gentlemen, the leading thought I have tried to leave with you this afternoon is that it seems to me that we have passed the point, we have answered the question of whether or not the proposition you have presented to you here is worth while. I think there can be no doubt about it.

\section{Lumbermen's Activities, Past, Present and Future By J. Lewis Thompson}

I have been requested to tell you a little something about what we have done ourselves in development, what progress we are making in our cut-over lands. I can't say it in any boastful spirit, because I have fought the opposition of our stockholders, and I have spent money which is considerable for us, and it has been spent just because I took the bull by the horns and went ahead with it. Some of our stockholders think I know naught of what I am doing, and the future may answer that question; but for the present we have done this: We have already fenced 60,000 acres. In that 60,000 acres we have some

10,000 Acres to the Pasture six pastures. We have five different ranches. In these different pastures we are using native cattle as far as we can-getting in good bulls. On one of our ranches we have a registered herd of Herefords with which we propose to raise our Hereford bulls, and on another ranch the Shorthorns. We have been going at the thing in a systematic way, but we have been groping a little bit in the dark. Last year we had 300 acres in cultivation. We built thirteen 100-ton silos, with sorghum silage. We find that sorghum gives twice as much ensilage per acre as corn does. We may not know how to take care of the corn, but we have found that sorghum produces twelve 
to twenty tons of ensilage per acre. This year we have a hundred acres in peanuts; we have forty acres in sweet potatoes; and we have about 300 acres in sorghum, and we propose to build twenty-five silos this year. We figure a ton of ensilage will carry the cattle you have to feed-will carry one head through the winter-and puts them on the grass in the spring in fine condition, so that they start right off to growing. We have the only dipping vat in the two counties we are located in.

The question, "What part is the lumberman to play in the upbuilding of the Southland through the proper development and use of the vast areas of cut-over lands that are as yet largely unused?" is one that every timber and timber land owner has a right to be interested in, and is, I trust.

The lumber industry of the South came to life after the Civil War. Previous to that great war the South was given over almost entirely to the production of cotton. It was a land about equally divided between aristocrats and poor whites, with the negroes for the laboring class. In those days the lumber production of the country came from the North, but as the price of stumpage and the value of lumber advanced in the Northern territories, the lumber folks naturally began to seek other and newer forests and the South came in for a large share of their attention.

Then began the development of the forests of the South. What this development has amounted to, and what the lumber industry means to the South today, is a matter of fact with which we are all familiar. $\mathrm{He}$ is the largest employer of the South-a great community builder-and a leading spirit in his locality. The lumberman is essentially a pioneer. He seeks new forests when his old ones have been cut away, and he builds up and develops the territory in which he chooses to locate. Behind the lumberman come farms, schools, villages and eventually cities. Whenever you find him, you find a constructive worker. and a natural builder.

As an individual, the lumberman stands high among the industrial people of the land. As a citizen he is known always for his activity, his progress and his generosity.

As an industry, there is much for the lumber folks to do-a world of needful work that must be done-and a great field of undeveloped opportunity that stretches out before him in every direction. The opportunities that present themselves to the

Lumberman Blazes the Way for Civilization
Early Days of Lumbering in the South 
lumbermen of the future are greater even than those that presented themselves in the past.

The lumbermen of the Southland are the owners of enough land at present barren to build a new world. They have in their possession the potential makings of a veritable empire, it is their privilege, if they will grasp it, to carry out a great work for the

"Cut-Over

Lands Could Feed the Nation"
Combining a Patriotic Duty and Profitable Investment development and upbuildings of the entire South. There is enough cut-over timber land in the hands of the lumbermen of the South today to feed this entire nation, if properly cleared, fertilized, cultivated and farmed. The possibilities of this land for farming and growing purposes has no reasonable limit. It is the most fruitful soil within the limits of the continent. It will raise anything and everything, within reasonable limits.

The lumbermen have the ability to handle the problem of handling and developing the cut-over lands of the South. They can do so with commercial success, because properly handled, there is money to be made in the work. The argument that has long been advanced against the lumber manufacturer doing anying specific with his cut-over lands was that no decent return could be made on the investment and he was not in position to develop this land out of charity.

The demand for better soil and newer farming districts has gradually increased the values of the Southern land that once grew forests, and today it is a possibility for men to take this cut-over land and make a success of developing and selling it for farming purposes. This is a proposition in itself that requires specific handling, and the great trouble with the mill man has always been that he was so busy running his mill that he could not and would not divide his attention.

He can, however, in the future co-operate in the work that is proposed for developing these lands, and may do much without actually giving all his personall attention to the matter. I believe that he will not be slow in manifesting his willingness and ability to co-operate in the great work that means at one and the same time an excellent investment financially and a great work for the future. There are, therefore, both financial and sentimental reasons why the lumber manufacturers should start now to develop this great heritage of potential wealth that Providence has bestowed upon them.

There have been times, I admit, when many of us have seriously questioned whether this Providential bestowal was in 
the nature of a gracious gift, or a full-grown millstone to be carried around our necks. That time has passed, however, and there are few of us today who do not appreciate the value of these cut-over lands, and have not some general idea of their future importance.

In the past the lumberman has accepted his various trusts and handled them well. I know that he will do so in this case. He came to the South, saw the possibilities of the forests for the future, bought and developed same on his own initiative and without outside financial assistance built his plants and his railroads, developed the country, acted as home builder to the nation, solved his industrial, commercial and labor problems, and did much to develop the South from a strictly cotton country to a great industrial part of the commonwealth.

He is able to do much with this heritage of undeveloped cut-over lands, which is not really unlike the wealth of forests of the South, when he first encountered them. Cut-over land today is fully as valuable a present asset as were the great forests of the South when the lumberman first invaded them. The future possibilities of the land are easily as great as the possibilities of the forest have proven to be. An investment in these lands today can be reasonably expected to be a better investment than an investment in pine timber in Louisiana or Texas would have been fifty years ago.

The ownership of the great cut-over lands of the South is largely in the hands of the lumbermen. A great trust has been thrust upon them. The question of what shall be done with these vast holdings is one that has been growing louder and more insistent with every year that passes. It is really a mighty heritage-one that may be developed into boundless possibilities. The possibilities are limited only by the efforts that will be made in this direction.

In the days to come, when history of the South is written, will the lumberman be able to lift his head and report that he has accepted his heritage and developed it as commanded us in the parable of the ten talents, or will he be kept side-stepping, trying to find an alibi and explain why he did not do so? That question is soon to be settled, but with the faith that I have in the ever-readiness of the followers of the lumber industry to do their part, I know that the record will be kept straight, and

Lands Worth as Much as Original Forests

Lumbermen Will Measure Up to His Responsibilities 
that when the time for writing this history comes, the lumber folks will find their credit side of the ledger to be well filled.

They will develop these cut-over lands; they will assist in the tilling of the soil; they will develop and build up great communities where their forests once stood; they will encourage and make possible scientific farming; they will send their children to agricultural schools, where they will learn the great lessons of proper use of the soil; they will lay a great foundation for their children and their children's children, to assist them in carrying on the work of making this Southland the Great Garden Spot of America.

\section{The Railroads' Part in the South's Development \\ By J. C. Clair}

Industrial Commissioner of the Illinois Central

Railroad

Farms and Railroads Interdependent

Mr. Chairman and Gentlemen :-I was invited to attend this Conference, but was not told I would be called upon to make any remarks. It was a pleasure, however, to come down here to meet with you, and in looking over your work and appreciating it from all angles I only regret that real transportation men are not on the program. If there is any time in the history of this country when the two greatest and foremost industries of the world are to be appreciated and should be appreciated, it is at this time-agriculture and transportation-they go hand in hand, one with the other.

It certainly was inspiring to listen to that gentleman, the Assistant Secretary of Agriculture, this afternoon; as well as to the other men who followed and preceded him. I deem this one of the most important conventions upon one of the most important subjects that has come before the Southern peoplein fact, the nation as a whole-and I am glad to be here this afternoon and speak for four or five minutes.

We should enter into this matter in the spirit of real cooperation, as partners, and we can learn much from each other. 
The Illinois Central railroad, appreciating the Department of Agriculture at Washington, the administration field work of that department; the agricultural colleges of the various states through which our lines traverse, took it upon themselves, a few years ago, to co-operate with those agencies to the best of their ability.

Mr. C. H. Markham, president of our road, is vitally interested in your development work. He made his mark, years ago, on the Southern Pacific in this work; and it is not many years since he was only a station agent; but through his activities, and what he was able to bring about with the various administrations interested in development work, he is today President of one of the largest corporations of transportation in this country.

He directed me to look over the Southern Mississippi Valley to ascertain what further could be carried on-what should be done at once.

- I went over the State of Mississippi in the interests of the creamery business, feeling that that great state should make its own butter. I discovered there were two creameries in the state two years ago last fall-one carried along on the Mobile \& Ohio, and a small one at Brookhaven, on the Illinois Central, a failure for very good reasons. I do not desire, however, to overlook the Creamery Co-operative Dairy College, at Starkville, Mississippi, which, of course, was a success-a demonstration to the people of that state who wished to consider the dairy business. It was my recommendation that all communities served by the Illinois Central, where they would guarantee sufficient cows or butter fat, construct a proper building in an up-to-date way, that our company furnish the business manager, at our expense, for one year; realizing, that in a year's time, such a man could picture to the farmer the importance of getting a good milk cow, explain to him the separator, explain about utilizing the natural fertilizer, etc. Several of those co-operative creameries are under way, after two years, and all are a success. At this time, together with those who have taken the work up in a private way, there are seventeen creameries in Mississippi. I sincerely hope that the state will call upon the Illinois Central within the next twelve months for sixteen more creameries managers. We will be pleased to furnish them at our expense.

Creamery Development in Mississippi 
In taking the schools to the farms we have 32 demonstration farms in the Southern Mississippi Valley. This last year we distributed 90 pure bred sires in Southern Illinois, Kentucky, Tennessee and Mississippi in the interest of improved live stock, both beef and dairy types, Angus, Shorthorns, Herefords, Guernseys, Jerseys and Holsteins.

Now, gentlemen, in this work of activity and co-operation, we find it is useless to hand something to somebody on a gold platter. The Lord helps those who help themselves, and that is the truth. In order to encourage the dairy business in the South-

Practical Cooperation With the Farmer
New Blood

Important in Cattle Raising ern Mississippi Valley-and by the way, in the presentation of those sires we would not, of course, allow one of those fine bulls to go into a tick-infested county-we think too much of the live stock; I speak here only of Mississippi, because there is no parish traversed by our line in Louisiana that is yet free from the cattle tick, and I regret that. Dr. Dalrymple, however, tells me that two or three of the parishes will be free in a few months, and when that time comes the Illinois Central will be right here with the bulls to co-operate with you, too; that is, if you want us, to.

Now, again speaking of those who should help themselves. We have pictured the importance of the dairy cow and the dairy business. By this time we realize that live stock is its most important division. That brings the first cash, then the hog and the poultry, and following with the steer and sheep. I am glad sheep has been mentioned here today, because we know that animal should be on those lands in great numbers in this part of the country.

This matter of education, gentlemen, you observe, changes everything; and right here, gentlemen, don't think for a moment that I make any reflection upon the people of this territory. I want rather to congratulate the people on the progress they have made in the last three or four years, and that, now you have a compulsory law, that by 1918 the cattle tick will be a thing of the past, is something that you are to be congratulated upon. (Applause.) Any community on our lines, from Southern Illinois to Louisiana, where they will organize the bankers and business men and have the farmers purchase dairy cows from outside the state, the Illinois Central railroad will furnish the sires. That is helping those who help themselves. I say from outside the state. I don't think it is along the lines of progress for Tangipahoa Parish to sell cattle to West Feliciana. I do think it 
is important to bring in good cows from the outside of your state. I assure you that we will not purchase a bull from any part of Mississippi to send it to any other part of that state. We demonstrate the importance of new cattle by taking in cattle from outside territory, and then you are starting immediately with new cattle.

I state this to show you what we have done and what we are doing in a spirit of co-operation. The railroads are a great factor in this work, and on this cut-over pine land proposition, and I sincerely hope that before the deliberations conclude, the interested delegates will organize a plan along conservative lines that will be so attractive that it will be simply impossible for any interested party, including the railroads, to get away from participating and doing their full share in carrying out such a plan. The railroads of this country have an organization known as the Railway Development Association, and will have its annual meeting at Louisville, May 9-10-11, and the Secretary of that Association, Mr. Welty, is present. I am glad to say that we represent 90 per cent. of the railroad mileage of this country, including Canada-and I might say Mexico, or we used to-and we would certainly enjoy having anybody attend that meeting who is desirous of our co-operation in the movement you have under way now. Secretary Vrooman told Mr. Welty and myself today that he would endeavor to be with us at that time.

Now, this Railway Development Association, gentlemen, represents the Agricultural, Industrial and Immigration Departments of the various roads, and you will readily understand from that that we are very much interested in everything pertaining to development. We don't claim any special credit for what the Illinois Central has done; we are not in this for philanthropy; we have a selfish motive. We realize that as the country develops the road develops, and therefore we are desirous of doing our full share and part in the general development work. I want to say to you people of Louisiana, Mississippi, Alabama, Arkansas and Texas, and the whole South, that we have, in our general passenger waiting room in Chicago, an exhibit of the kinds of soils and pictures of the most progressive farms in this Mississippi Valley.

Allusion has been made to the land man. If there is anybody I am prejudiced against, it is the land man, and in order to protect him and myself and the would-be homesteader, I am always frank

Promises Aid of Railway Association 
to tell him so. I only wish the man, in selling land in the Southern Mississippi Valley, could appreciate this fact: That

Make the Homesteader Happy when he conscientiously and to the best of his ability makes a homesteader happy, he is making his best agent. Human nature is the same all over, and when a man takes an interest in his home, that man is going to be an active agent from then on for that community. (Applause.)

As I said in beginning, it is the development policy of the Illinois Central to co-operate in every way we can in the further development of the South; and I hope the meeting will not close until some comprehensive, practicable plan has been brought about that we all can serve on,-and do so with pleasure; and I want to say that it will be a special pleasue of the Development Bureau at Chicago to point all the men we can this way; and when you men have your plans ready, whether you are on the lines of the Illinois Central or not, please give me your information, the number of acres you have to sell, and at what price. and it will be my pleasure to co-operate with you people also: because any part of the South, in helping itself, only helps the whole South and the Nation. (Applause.) 


\section{The Practical Aspects of the Problem}

\section{By Clement S. Ucker \\ Vice-President, Southern Settlement and Development Organization}

Gentlemen of the Cut-Over Land Conference: I am somewhat in the position of the gentleman who so very ably presided over your deliberations yesterday-I am under the necessity of introducing myself, and I proceed to so do without further comment.

The program this morning provides, as prepared by the Program Committee, for a few remarks from myself under the general head of "The Practical Aspects of the Problem." In view of the fact that I have been called upon to preside, I will take this opportunity to say what I have to say to you on this initial occasion.

The week before last, we had a conference of this kind at Wilmington, N.C. A gentleman of national reputation was about to address the conference, and another man, of more or less national reputation, was delivering an address. The man who was about to speak was sitting with me on the platform, and I noticed that from time to time he drew his chair nearer to the front. After probably fifteen minutes, he backed away, stuck . his manuscript in his pocket, and turned to me and said, "That man has made my speech." That is pretty largely the position of myself. All that I might say to you about the practical aspects of this problem was either touched upon yesterday, or will be today; and whatever I might say to you now in the limited time at my command is largely of a superficial character.

However, there are some thoughts I want to leave with you. On yesterday we listened with absorbing interest to the address made to you by the Commissioner of the United States Land Office. The one point in his address that stood out most prominently to me was the fact that in the public domain, in the far western country, wherever there has been thrown open to the settlers lands that certainly could not be of much greater value 
Cut-Over

Lands Must

Be Made

Assimilable

South's

Advantages

Little Known than these lands now under consideration would have, they were promptly absorbed by the public; all of which brings us to this one thought-why is it, that at this late day, this vast area of land still remains? It seems to me there are two reasons, two main underlying reasons; one of them is perhaps the fact that these lands are not in what I choose to call assimilable form. They have not been put into condition; they have not been given that finished touch that, after all, may be necessary to cause their assimilation. You will remember that Mr. Tallman on yesterday pointed out to you that there were.areas-and I know of my own knowledge of areas in the west-in Western Nebraska, as I recall it, where lands were offered for settlement for years, and Congress changed the form, increased the area and terms and conditions, and promptly the land was absorbed. Therefore, it seems to me in all probability, that these lands are not in assimilable form; that perhaps those who have been engaged in the exploitation of lands, engaged in colonization work, have not employed the best and most comprehensive talent in developing those factors.

The other outstanding fact, of which I am entirely convinced, is the fact that the public mind has not run in this direction. Ever since the Pilgrim Fathers left Massachusetts; ever since the Cavaliers left the tidewater of Virginia or the Carolinas, there has been instilled into the minds of the people that westward lay the great opportunities; and there has never been concerted action to instill into the minds of the people that there were great and equal opportunities in the Southern country. So it seems to me that is, after all, one of the very important factors, if not the most important factor-publicity-instilling into the minds of the people the facts as they are and that there are opportunities in this lower Southern land. A single effort cannot bring that about. A single corporation, no matter how much financial backing it may have, no matter what talent it may have, cannot bring it about, because the task is too gigantic and because it requires too long a sustained effort; and what may be true of that is also true of every other single agency, whether it be transportation lines, whether it be part of a state, or whether it be the individual effort of the land-owning and land-financing corporation.

After all, gentlemen, there are, as I see it, four factors that go to make up a country. There are, transportation; there are 
lands in adaptable form; those two things, coupled with publicity, ought to give people. Now, it seems to me that the problem you gentlemen have before you, and which is no different in any single respect, save that of climate and location, from Western North Carolina or Eastern South Carolina, or South or Central Georgia, or Florida, or Eastern Texas-those great cut-over lands present the same problems; and it seems to me that we will get down to this problem when we have effected some form of organization that makes the man who owns the thing we are trying to operate upon an interested fundamental part of the solution of the problem, and when all other interests can rally around that basic effort: when the talents of the Federal gorernment may be brought to bear; when the effort is proving itself to be one of broad, disinterested, national scope; when the Federal government can join itself with the States, who, after all, must bear the brunt of this through their colleges and agricultural schools; then, it seems, we will be a long way towards solving this problem; and if that fails of solution, then it seems to me we will have to look to some source that we know not of in this day to bring about its solution. But so far as I am concerned, for the several years I have been connected with this problem, that represents my conclusion with respect to it-that the men who own the land; the men who have this thing; that the men who, in the trend of our affairs, find themselves with this thing upon their hands, have a very solemn duty to perform. As the public domain of the United States shall pass away, it seems to me the vital aspect of this problem increases. This land is in private ownership. The government does not own it; the States do not own it; private individuals own it; and from the aspect of a progressive, a solidified nation, it seems to me that it behooves those who own this land, together with all other agencies which may be interested in it, to do all they can to co-ordinate their efforts and to adopt a plan of action that will be able to command the support of all, and that will be continuing in its efforts.

Gentlemen, this land represented here today covers an area embracing the eastern part of Texas, Arkansas, Southern Missouri, Mississippi, Louisiana, Alabama, Western Georgia and Western Florida. We are very fortunate today in having with us the representative of one of these great states-a state that I am advised-a state that I know from my own personal knowl-

The Land Owner's Duty to the Nation

\section{Four Factors That Make a Country}


edge-has, within a very remarkably short period of time, made a remarkable progress in agricultural development. We are very fortunate in having with us the Chief Executive of that state, a man who has done a great work towards the accomplishment of the end I refer to. I have great pleasure, gentlemen, in introducing to you, His Excellency, Governor Charles H. Brough, of Arkansas. (Applause.)

\section{Natural Resources of the South-Arkansas as a Developing Factor By Hon. Charles H. Brough}

\section{Governor of Arkansas}

Gentlemen of the Cut-Over Land Conference: I deeply appreciate the honor of the invitation extended to me by my friend, Mr. Putman, of the Southern Pine Association, to be present and deliver an address before this representative body of the captains of industry of the South; men who are building more wisely than they know,

"Men who are broad-backed, brown-handed, upright as the pines, And by the scale of a hemisphere shape their designs."

You have heard a great deal, my friends, about the Arkansas of the past-the Arkansas traveler, wearing his coonskin cap and coming. to the forked roads, not knowing which fork to take. I want to tell you gentlemen from Louisiana and Missis-

Arkansas of the Past and of Today sippi and the other Southern states that there is a new Arkansas at the present time-an Arkansas with an empire of vision in her brain. New York has been called the Empire State of the American Union because New York is the richest state in the American Union. New York can boast of the roseate hue of her apples and the amber of her fields of wheat; Arkansas can boast that her apples have captured the First Prize at the last six International Expositions, and the largest apple ever placed on exhibition in the world *was an apple raised by a 
Benton County farmer, three and a half miles from Sulphur Springs, which weighed $29 \frac{1}{2}$ ounces. (Applause.) New York can point to the beautiful tint of her cherry blossoms; Arkansas can boast of the state of the famous Alberta peaches that nestle in the snow-white virginity of her soil; and the only solid carload of peaches ever shipped abroad was shipped by an Arkansas agriculturist from the greatest peach orchard in the world, located in Pike and Howard Counties, Arkansas. New York has only a small mineral belt; Arkansas claims 18 counties of her state that hold valuable deposits of anthracite coal; and it may be interesting to know, in this day of our nation's crisis, when we are dependent upon the United States Navy to maintain the freedom of the high seas, that the smokeless coal now used by the United States Navy is mined in Sebastian County Arkansas. Arkansas ranks first in production of ash, cottonwood and red gum; third in products of hickory and oak; and fifth in the production of pine in the United States.

We have at present about three million acres of cut-over timber in our state, and within ten years this amount will undoubtedly increase to approximately ten million acres, representing approximately, then, one-eighth of the total cut-over land surface of the Southern states, on the basis of 76 million acres.

Now, my friends, we join with our sister Southern states in believing that the time has come for a great industrial renaissance for economic development in our state; and because of this fact our Legislature has recently appropriated about two million dollars to meet the terms of the Smith-Lever Bill, for carrying the doctrine of agricultural extension into our state. We appropriated $\$ 2,240,000$ at the last session of the L.egislature to meet the terms of the Good Roads Bill, which will network our state with roads and construct about three thousand miles of improved roads within the next five years. We are the third state in the Union to be completely freed of the great evil of the cattle tick, having made Arkansas a state-wide free cattle tick sic? anking with Mississippi and Tennessee. We have appropriated $\$ 50,000$ to enforce the provisions of this Act. We have begun to realize, my friends, that the foundation of all educational progress, the foundation of all moral progress, is economic development. I am rather heterodox when I make this statement, my friends; but I don't believe a people can be thoroughly intelligent, I don't believe they can be thoroughly moral, I don't believe they can live

State and Nation Cooperate in Economic Development
Wonderful

Products of the Field and Mine 
up to the highest ideals of educational advancement, unless they have a bedrock of economic prosperity.

After all, industrial prosperity is the rock upon which this republic rests and upon which our South rests today, and the greatest problem, social and political, which is before you today is the problem of scientific agriculture-the problem of the colonization and improvement of these cut-over lands in the South (applause)-the problem of the foundation of the economic structure reared by human toil and held firmly in place by the average prosperity of all who have helped in its building. We think this average prosperity exists whenever there is a great middle class in our society-not a domain where the tenets of socialism exist, but where the people are all animated by loyalty to a common flag and a common country. (Applause.) A great French philosopher has said that civilization is like beer-froth at the top, dregs at the bottom, and the substantial part in between. Show me a nation or a section that has a great middle class of people and I will show you a nation and a section that is materially prosperous, that is educationally progressive, and that is morally what it should be.

We need to develop, therefore, our 76 million acres of cutover timber land in the South, in order to build up a new Southneither the top of society on the one hand, nor the submerged

Type of

People Best

Suited to

Develop CutOver Lands
South Destined to $\mathrm{Be}$ Nation's Industrial Empire tint on the other hand-but to flood the South with a great middle class of people, of people not tenants but landlords, and of people economically self-sufficient. Now, it is estimated by the distinguished gentleman who addressed you yesterday, who delivered such a brilliant address at Little Rock on Monday night, that of the 76 million acres of cut-over land, fully 15 million acres will have no second growth, and therefore are thoroughly adaptable to colonization. I congratulate the great railway systems of the South, and the great colonization systems of the South, that they are fully alive to the immensity and importance of this problem, and that they are utilizing their activities and their publicity bureaus in order to stimulate an immigration to this greatest of all undeveloped sections of our country. The South, my friends-and I know there are delegates here from other sections of the country, but I believe they will bear me out-the South is destined to be the great industrial empire of the American nation. The Middle West, the West, and the East have shown a wonderfully progressive spirit, but 
their resources are well-nigh utilized. They have, to no great extent, these cut-over lands located within their borders, and the United States must look for its most progressive development in the future from the Southern states. At the same time, in this development, we should look to the East, the Middle West, and the West and absorb a great deal of their progressive spirit; we should absorb their progressive spirit with reference to fine breeds of cattle. We have 500 million dollars worth of cattle in the South today, but I regret to say that a large proportion of it is common stock, stock that does not measure up to the best breeds; but the bankers and business men are rapidly introducing Herefords and Shorthorns and Angus and other cattle of a standard breed; and it is very interesting, my friends, in this connection, to know that the champion bull of the United States was raised in my state-the Point Comfort the 14th-raised by Colonel Miles; sold two years ago for $\$ 300.00$ and, after this bull won the First Prize at the Chicago International Stock Exposition, there was offered $\$ 25,000$ for this animal. We are rapidly developing improved stock on all cut-over lands, and this will mean a wonderful improvement in our form of agriculture. We need but to absorb some of this spirit and some of this progressivism with reference to the cattle-raising industry from the United States; and it will help the bankers, also, because of the 6 billion dollars invested today in the live stock industry of the United States, there are only one billion dollars' worth of loans based on this six billion dollar live stock industry. Heretofore, our bankers have required our stockmen to mortgage their lands and homes, and almost their wives and children, in order to get a loan on stock; but since the organization of the Federal Reserve System, and since cattle is now regarded as a liquid asset by bankers, on which loans can be made, a great opportunity opens up to the bankers and business men of the country to float a larger proportion of loans on the stock and cattle of the South.

As Mr. Vrooman told you yesterday-for I judge he called attention to this point-we are confronted with a mighty problem today in the South. We are importing from five to six hundred million dollars of foodstuffs each year. Cotton is still king in the South, and by virtue of the splendid prices we have been receiving for cotton in the past three years, cotton is more firmly intrenched than ever before; but, my friends, the time has come, in connection with this great war, and in connection with our in-

Banks Now Willing to Loan Money on Cattle 
The South's Duty to the Nation and to Itself

The

Lumberman's Opportunity dustrial development, when a large proportion of these cut-over lands in the South should be used for raising cereals, and legumes, and foodstuffs of all kinds. An army travels on its belly, is an old saying; but the boy in the furrow can render just as patriotic service to the United States Government as the soldier on the battlefield. I doubt very much, indeed, whether more than a division of American troops will be sent to Europe; for they tell us that it requires thirteen months to prepare an army. Roosevelt may be sent over with a regiment to take its place out there in the trenches, to plant Old Glory alongside the Tri-color of France, (applause) in order that we may return our gratitude to France for the gift of Lafayette and Rochambeau, those great French soldiers, during the Revolutionary War; but with the exception of a division or two it is not likely that an army will be sent to Europe during this international war; but we will be expected to feed our Allies; we will be expected to send great convoys of ships to the Allies: and we will be expected to feed ourselves: My own state last year imported 65 million dollars' worth of foodstuffs; and yet in Arkansas we say that a wall of isolation could be erected around our state and that we could be self-sufficing and independent-and yet the startling fact stares us in the face that last year we imported 65 millions of foodstuffs in one state, and about 600 million dollars of foodstuffs in the thirteen Southern states.

Now, my friends, we should preach a diversified agriculture: we should preach the planting of cereals and legumes and soy beans and clover crops of all kinds; because the crops of the West are going to be commandeered by the United States government; and, as Mr. Vrooman said, we must either feed ourselves or we must go hungry. Now, the great lumber men of the South-and there are thousands of them within my own state of Arkansas-have a glorious opportunity in this respect. Fully 70 per cent. of these lands are rather favorably located within a short distance of railroads. Colonization plans could be made most attractive for the settler from the older sections of the country; and the experiment stations will co-operate with the railroads and the lumbermen and with the other agencies for industrial development of the South in attracting settlers to these cut-over lands. Aside from this, my friends, as long as the cutover lands remain in their present state there is not only a great economic waste to the South as individuals, but there is a great 
economic waste to the State itself. For instance, when the timber was standing on these lands, these lands were found on the tax books at about $\$ 18.00$ an acre; now they are at about $\$ 2.00$ an acre. Look what the State of Arkansas loses on three million acres assessed at only $\$ 2.00$ an acre, and I take it that this is true also of Mississippi, Louisiana, Texas and others of the Southern states. There is a direct economic loss out of the revenues due the Southern states, to say nothing of the economic waste to the South as an-industrial section; and so we are going to make an appeal, my friends, for these lands to be offered to settlers at attractive prices. I am going to get in touch with John H. Page, our Commissioner of Agriculture, along these lines, and with the University and Experiment Stations, the University of Arkansas and the Agricultural Colleges of our state, and see that experiments are conducted on these cut-over lands designed to attract settlers; and I believe that in this way, within the next year, we can certainly feed ourselves and we can certainly lay the foundations for a great industrial empire.

In connection with the stock industry of the United States, I trust that at this meeting of the Cut-Over Land Conference a resolution will be adopted, petitioning our great President-than whom, in my humble opinion, no greater President has ever sat in the presidential chair, combining as he does, the patriotism of a Washington, the philosophy of a Thomas Jefferson, the constructive ability of an Alexander Hamilton, the sweet charity of an Abraham Lincoln, the judicial temperament of a William Howard Taft, and the energy of a Theodore Rooseveltgreatest men who ever occupied the presidential chair (applause) - that a resolution will be passed at this session of the Conference petitioning the President of the United States to admit, free of all import duties, cattle from the Latin-American countries to our Gulf ports. in order that the South may have the best breeds of cattle, and in order that these cut-over lands, which are admirably adapted for pasturage, may be supplied with the very best breeds of cattle from the Latin-American countries. I believe this would be a great constructive measure that could be passed by the Cut-Over Land Conference.

My friends, there is an inscription on a monument in Atlanta, Georgia, erected to Benjamin H. Hill, which reads:

"Who loves his country, loves all things,

And all things will bless him;

Economic

Waste in

Present

Situation

Arkansas to

Begin Cut-

Over Land

Experimental

Work at Once

Latin-Amer-

ican Cattle

Suggested to

Stock South-

ern Farms 
Who lets his country die, lets all things die, And all things dying, curse him."

If these words, written on the monument of Benjamin $\mathrm{H}$. Hill, in Atlanta, Georgia, be true, then it is incumbent upon us, as the sons of noble American sires, to put our shoulders to the wheel to develop the great American empire that we have at our disposal today. I have no fear of the result of this present European War. I believe the entrance of the United States is the de-

America

Seen as Deciding Factor in the War ciding factor in the scale of this War. I have always believed in the prophecy shown in the Book of Revelations, and I think it is literally true-in the Book of Revelations we read: "A woman shall go forth in a wilderness and upon a barren rock shall give birth to a child, and that child shall one day rule the world." In 1620, our forefathers, driven by constitutional oppression, left Mother England in the Mayflower. On December 20, 1620, that Mayflower reached Plymouth Rock, and there, on a barren rock, in the wilderness of North America, was born the child of these United States; and who, in this intelligent and patriotic audience before me today, doubts for one moment that that child today rules the world? (Applause.)

"Not for our own land is Freedom's flag unfurled, but for world."

Aside from our economic development, in which we cannot compare with either Germany, France or England, the United States today has the most remarkable form of government on the face of the globe. Mr. Gladstone, England's greatest statesman, once said that the American Constitution was the most remarkable document that ever sprung from the brain of man.

"America takes but to give again, As the sea returns her water in rain, So she gathers her seed from the haunted of every crown and creed.

America's Greatness Recognized Abroad
Her Germany dwells by the gentler Rhine, Her Ireland sees the old sunburst shine, Her Norway still clings to the mountain pines;

And broad-based under all is England's broken-hearted mood, As rich in fortitude as ever went from her island wall.

Fused into her candid light,

All races here to one great race unite. 
Hereditary foemen forget their slogan, kith and clan.

'Twas once glory to be a Roman, America makes it a glory now to be a man." (Applause.)

And then, my friends, while, as I have said, the economic development of our country is not parallel with the economic development of Germany, France or England, it must be remembered that we are today the only great exporting nation of the world-the United States and the Argentine Republic. There were, in the last fifty years, only three great exporting nationsthe United States, Russia and Argentine Republic; but since the entrance of Russia into the war, the United States and Argentine Republic remain the only two great exporting nations of the world.

To slow the wonderful resources we have at our disposal, a brilliant writer on the Pall Mall Gazette, England's leading paper, paid a rather humorous but effective tribute to the absolute dependence of the average Englishman upon the United States for everything the Englishman eats, drinks and wears. He said-in the morning the Englishman gets out from between his New England sheets, shaves with Williams' soap and a Yankee safety razor; adjusts his Kentucky suspenders on trousers manufactured in Massachusetts; slips on his shoes manufactured in St. Louis over socks manufactured in North Carolina, and goes down to breakfast.

The breakfast of the Englishman consists of some beefsteak from a middle western cow, while his wife plays with a piece of Chicago ox tongue, and his children amuse themselves by eating some cereals or rolled oats from the Middle West. The Englishman then goes to his office. At his' office he finds everything is American. He sits down on a Nebraska swivel chair before a Michigan roll top desk; writes his letters on an Underwood, Snith Premier, Remington, Caligraph, Oliver, Royal or other typewriter of American make, and signs his letters with a Waterman, Paul E. Wirt or Parker fountain pen, all made in the United States; and puts his letters away in a letter file made by the Macey file Company, of Grand Rapids, Michigan. He then goes out to lunch. His lunch consists of some roast beef taken from the same middle western cow; flavored with some Pittsburgh pickles; and tops it all off with some canned peaches from old Arkansas. (Applause.) 
Figures Show Country's Amazing Economic Resources
American vs. German Ideals

And so, the economic resources of our country are tremendous. If the wealth of 285 billion dollars were equally divided amongst us, we are told by the great economists that there would be $\$ 1,385$ to the credit of every man, woman and child in the United States. In spite of the fact that we do 96 per cent. of our business on credit, by the use of checks and other forms of exchange, there is in actual circulation in the United States $\$ 38.40$ for every man, woman and child in the United States. Our 285 thousand miles of railway represent three-fifths of the railway mileage of the world, of which the South has approximately 50,000 miles; and our freight rate today of three-quarters of one cent for carrying one ton one mile is the cheapest freight rate in the world.

But, my friends, in spite of this great economic development, in spite of our wonderful form of government, we have not adopted the scientific form of intensive agriculture that is practiced in Germany, in France and in England today. We have not utilized our forests. Why, the substitution by Germany of forest products instead of cotton, instead of nitroglycerine, and instead of cotton absorbents, shows the value of the proper utilization of the forest supplies, and this has enabled Germany-our great enemy in this war-to wage the war with so much ferocity up to the present time. It is her scientific training, her preparedness, her efficiency.

But I rejoice, my friends-and I say this with due respect to our German-Americans, for I believe they are going to be loyal to Old Glory during this war; I believe every one of them will be loyal-I rejoice, however, that in the United States we have the ideal of character, while in Germany they have the ideal of efficiency. In Germany a man is simply a cog in an organization, and he is worked just as much as a $\operatorname{cog}$ would be worked in any kind of a machine. In the United States the ideal is of character. What we need in the United States, and particularly in the South is the blending of the two ideals-character and efficiency. Our men are a high-toned men, who wear their consciences as their kings, and wear the white flower of blameless private and public lives. Character is one of our inheritances; but, my friends, we lack the ideal of efficiency in the South. If we could but blend the two ideals of character and efficiency in our American civilization, and particularly in our Southern civilization, we would have a character fashioned that would pass all 
nations in the formulation of their national design. I therefore appeal to these captains of industry of the South and the Middle West, who are represented here today, in developing these great cut-over lands to go out and, in your colonization plans and in the management of your industrial work, preach the gospel of blending the two ideals of character and efficiency. I beseech you to preach the gospel that the South should feed herself; that we should be a self-sufficing section, rather than an importing section. I beseech you to go out and to use your means-for most of you are men of means and influence-to better the condition of our rural population. Eighty-seven per cent. of the population of the South live in places smaller than 2.500; and they, after all, are the saving remnants of our econonic civilization. I beseech you not to pursue a selfish policy with reference to putting your cutover lands on the market, to sell them on reasonable terms, at good terms of credit. I appeal to such live citizens as, my friends, Mr. Putman, who has been honored by being made Advertising Manager of the Southern Pine Association; Mr. Ucker and other distinguished gentlemen, the editors of all the trade journals, to present before the people of the United States the great economic possibilities of these cut-over lands.

My friends, we have a new South today. Let it be a new South in every way. God grant that the traditions of the old may prove an incentive to the progress of the new. God grant that you and I, in our respective spheres of life, may see to it that our wonderful undeveloped resources are developed; that the forests, that like giants stand to sentinel our land, are properly conserved; and then we may say with the poet:

"Henceforth, ol Southland, we look up to thee,

Not down at other lands.

Arise, arise, be not proud,

Be humble and be wise,

And bow thy head to the

Great Unknown One, who on high

Hath willed that as a land

Dixie shall never die!" (Applause.)

Combine

Character and Efficiency 


\section{Soils of the Coastal Plains Area By C. F. Marbut}

\section{In Charge, Soil Survey, Bureau of Soils, United States Department of Agriculture}

Natural Advantages of the South

Lands of the West and North

Mr. Chairman: It is one of my social theories that if we could fill every man's belly and cover his back we would solve most of the social problems. I am perfectly willing to say that this is just like most sweeping statements, but it contains, nevertheless, a certain amount of truth. The question of filling bellies and covering backs is partly, at least, a question of soil. The soil is at least one factor, and an important one in doing both.

The South is very much favored in its wonderful climate, in its abundant rainfall, its warm winters, its long growing seasons, and in the great variety of crops which that climate permits it to grow. In other parts of the United States, as was so clearly brought out by Commissioner Tallman yesterday, the available land is pressing pretty close up to the possibility of crop production on that land. I have had some connection with the classification of lands in the national forests, and many times within the last three years I have recommended to the chief of the Bureau of Soils and the chief of the office of Forest Reserves, the opening up for settlement of tracts of land which I knew positively could not ripen a wheat crop. It was perfectly evident that a wheat crop could not be ripened on it because of its Northern location, or its high altitude. Yet, that land is sought by a great number of people, and because of the strong demand for that land, and because of the fact that the soil is good, and because also of the fact that the land will grow grain hay in a region where summer grazing is important, it will probably enable the farmer to make a living, especially if it is carried on in conjunction with grazing in the national forests in the summer time. I make the preceding statement merely as an illustration of the kind of land now being taken up by settlers in the far West and North. In the South no such climatic conditions exist. There are tremendous areas of smooth unoccupied land in the South where the growing season is long. 
The Southern part of the United States is an area widely different from any other area of the same size, either in Europe, Asia or Africa. The position in Europe that corresponds to the Southern part of the United States is mainly mountain land, and only a very little of it is open to utilization by man. The same thing is true of Asia and that part of Africa that corresponds climatically to the Southern Coastal Plain of the United States is largely a desert. Fortunately the desert in America corresponding to the desert in Africa happens to lie in the Gulf of Mexico where it doesn't do any harm. We have a region here that is smooth in topography, has a high rainfall and climate favorable to agriculture.

The character of the soil in any place at any time is due to two fundamental things. This is a rather general statement, but will enable us to get to the point. One is the character of the material from which the soil cane. The other is what has happened to that material since it began to exist as a soil. The main thing that influences a soil after it has been formed is the climate. The way climate influences that soil is largely through the action of water, and where rainfall is very heavy leaching goes on at a rather heavy rate. Furthermore, the leaching or soluble effect of the water is increased in its effect by high temperature, so that in a region where the annual temperature is high and the rainfall heavy, the soil soon becomes thoroughly leached. What does that mean? It means that the soluble material in those soils has been carried away and taken to the sea. It means also that a large part of the minerals in that soil, those that are easily decomposible, have been decomposed, and the salts of which they are composed have been taken out of the soil. That is just the condition that exists in a large part of the South. We have here a region of high rainfall, a region of long summers, a region of warm winters, during which the soil does not freeze: during which, therefore, the rain can act upon the soil all the time, both summer and winter. The result is that Southern soils are pretty well leached. The result is that a large part of the soluble constituents in that soil is carried out, taken away and carried to sea. These soils differ very much from the soils of the wide plains of the West, for example, where the soluble material, at least in places, is so high on account of the great abundance of that material, that plants cannot grow. We call it alkali, but it is nothing more than an excess of soluble material in the soil. We have just opposite of that condition of things in the Southern and Southeastern part of the United States. These soils, especially the

Climate's

Influence in

Soil-Making

Tremendous Possibilities of Long Growing Seasons 
Difficulties of the Northern Farmer mineral salts, were washed out long ago, and now in addition to those things being gone, the minerals have been extensively decomposed and their constituents carried away. To illustrate that I will call your attention to a table of Southern soils I have here.

I have used here the names we use in the Bureau of soils classification; and I have given the percentages of potash and lime and silica. Of course, silica is not one of the elements of fertility. The Orangeburg Sandy Loam, which is an important soil in Western Georgia, in Central Alabama and Eastern Mississippi, and quite an important soil also in Central Louisiana, and also in Texas (but not very abundantly in Texas), has $1 / 10$ of 1 per cent of potash. Soils in other areas will contain 2 or 3 per cent. This contains $1 / 10$ of 1 per cent. What I want to point out to you is that the Southern soils are pretty well leached through natural conditions-not due to Southern agriculture. The farmer has not leached them out. Nature did it. It is the result of natural processes. It is a condition that the Southern landowner and farmer must meet. How does Nature compensate the Southern farmer for this soil condition which she has given him? The compensation lies in just what I mentioned first, in the tremendous advantage that the Southern farmer has in his climate. The settlers who take up land in the high mountains of the West and North find it absolutely impossible to lengthen their growing season one day. They find it impossible to increase their rainfall $1 / 10$ of 1 inch. They must meet conditions that they cannot change. The Southern farmer, however, is not in that position. He is not under the necessity of resigning himself to the soil conditions established for him by nature. Since his soil deficiency is merely one of soluble mineral matter, and a supply of organic matter they may be supplied by him. The great development of the fertilizer industry within the last fifty years has made it possible for the Southern farmer to purchase an abundant supply of mineral fertilizer for his soil, while his climate favors the rapid utilization of all organic matter that he puts into it.

The Southern farmer labors under a slight disadvantage in the nature of his soils. He basks in the favor of the tremendously: advantageous climate and is able to overcome the disadvantage of his soils by the use of fertilizers, which are not extremely expensive. That is essentially the situation so far as the character of Southern soils is concerned.

There is another factor in the handling of soils in agriculture, with which agriculture has to contend-and that is the question of 
topography. I don't mean elevation necessarily; that comes in as a part of the climate; but I mean the local relief of the country, that character of the country which says you can either use machinery or you cannot-you can use this land for crops or for pasture. I have no map here showing the characteristics of the topograply of Southern soils, but I will use these maps; and do not let the coloring of these maps divert you from what I am saying; because this coloring does not represent topography at all.

In general I will say that the topography of the coastal plain is, as a whole, smooth. It lies low and the topography is smooth; but that does not mean that it is flat; and there are certain areas in which the topography is as complex and in which it influences agriculture as much as in the Rocky Mountain region.

In Alabama the edge of the coloring here represents the interior part of the coastal plain. That is not coastal plain country, and since this Conference is concerned with coastal plain country only, that represents the northern edge of the country we are considering (pointing to map). Along the edge of the coastal plain is a region where the topography is pretty rough in detail. It is relatively high; there is abundant rainfall, and that has enabled the streams to cut it up pretty thoroughly. There is quite a percentage of that country that is too rough for cultivation. Then through this belt is the Black Belt and low belt of Alabama. When I say black I apply that to the soil and not to the people. It happens though that both soil and people are largely black in that belt. Running just about south of it is a belt of rough country where the country rises suddenly from the lowland of the black belt, and then southward slopes gradually down to the sea. The North-South coastal plain profile would begin at the North with rough country, and then would follow a low smooth belt, and then suddenly it would rise to an elevation of two hundred feet above that region and slope thence gradually to the sea. In addition to these rough belts there are others along each side of all the larger streams.

In between the country is smooth. Down in this region it is all so low that it is relatively smooth.

Taking this region as a whole it is a region of smooth country, and Florida is still smoother.

In Mississippi the same rough belt exists just south of Meridian and extends inward a little way, but gradually fades out. The rim of it extends northward in this direction, flattening out as it

The Soils of Alabama
Topography

of Coastal

Plain Region Smooth 
Mississippi and Louisiana From a Standpoint of Lands

Arkansas Presents Varied Character of Soils

Erosion's Effect on Soil Fertility goes, and a little less broken in this region. Then, along the western side of the State, there is a belt of country which is relatively high, but is thoroughly cut to pieces by streams. This consists of the hill lands just east of the Delta.

In Louisiana this region is all smooth, except along the eastern side, where it is cut up by streams flowing into the Mississippi. In this part of the State there is more or less rough land-possibly 10 per cent-a little rough for cultivation under conditions of Southern rainfall; and going southward it slopes to smooth land down to the sea.

In Arkansas we have two mountainous regions. By the waythe request that was extended to me by Mr. Moore of the Southern Pine Association, stated that they desired to discuss Arkansas as a whole-not simply the coastal plain part; so I have colored the whole state. There is a mountainous belt in this region, just south of the Arkansas River lowland, a high plateau belt in the northern part, and a high limestone region in the extreme northern part. The eastern part of the State is low. In the mountain regions, by no means, is all of the land too rough to cultivate. The rough topography consists of certain minor ridges which are high and steep with intervening lowlands, two, three and four miles in width, all of which are now cultivated to a great extent and which will be more cultivated in the future. The North Central part of the State, on the other hand, consists of a high plateau except where valleys have been cut into it. The northern edge drops off steeply. The southern edge also has a narrow belt of rough country. In general it is a high plateau.

In Texas we include only a small portion of the eastern part of the State. In the northern part there is a good deal of relatively rough land. Then, as you go southward, the country gradually slopes off to a smooth plain at sea level.

Probably 15 to 20 per cent of the coastal plain lands of the South are rather too rough for cultivation under existing conditions here. What are those conditions? Warm winters which do not freeze the soil, and thereby expose it to erosion throughout twelve months of the year; high rainfall; the absence of thick grass over the timber land as well as the fields; the South being characteristically a region of no grass. The Southern farmer, therefore, has to contend with the two unfavorable conditions of a pretty well leached soil, and a soil which erodes easily. 
The colors of these charts show the percentage of undeveloped or unimproved land worked out from census data. This represents nothing but a compilation made from the census reports. This darker color represents an area where 80 to 90 per cent is unimproved; this represents 60 to 65 ; and here 60 to 80 . If the black belt could be sorted out from this belt we would have in the black belt an area where there is very little land not cultivated; but since the statistics are given according to çounties, and since each county includes this land plus the land lying outside of the black belt, I was unable to get the percentage of unimproved land in the black belt.

In Mississippi, in the southeastern part of the state, there is rather a large area, of which, according to the census reports more than 90 per cent is unimproved. Another belt 80 to 90 ; in this region 60 to 80 ; and here two areas are essentially the same 45 to 65,50 to 65 .

In Louisiana the unimproved area lies in the southwestern part of the state. More than 90 per cent of the area is unimproved, and a large part of that is quite smooth land. Here are two areas where 80 to 90 and 65 to 80 is unimproved; and over here is an area where a large part is unimproved, and becomes less and less as we go northward.

In Arkansas, there is no county-there are parts of the statebut no whole county where more than 90 per cent is unimproved. There are plenty of areas-small areas-where more than 90 per cent is unimproved, but no single county, so that the lowest percentage of unimproved land there is 80 to 90 per cent, and then, lying along the other side of that, we have land which has a higher percentage of unimproved.

There are two centers in Arkansas with a similarity in unimproved land; one in the Southern mountain region; the other in the high plateau of the North, extending beyond the sand stone plateau over into the redlands of the North.

In Texas you see a large area in the southeastern part of the state, which extends to the area in Louisiana, where more than 90 per cent is unimproved.

The white areas here represent level land; it is not coastal plain, and therefore not pine land; and they are not taken into consideration. That is the level land of Arkansas; in other words, it is not pine land. In Texas I only included a small part; and in Alabama I included all the coastal plain, but the northern mountain region 
Wide Scope of Southern Pine Association's Activities

The Character of Unimproved Lands

\section{Alabama's Uncultivated Millions of Acres}

was left out; and in Mississippi the level plain and the northern part.

These round dots show the location of the saw mills of the Southern Pine Association, compiled from a list sent me by $\mathrm{Mr}$. Moore. I had a draftsman take the list and locate the mills on the maps. Since this is a discussion of the Southern Pine Association lands, you will notice that the areas which we discussed are the areas that include all of the saw mills, with the exception of two in the mountains of Alabama.

The maps already shown were compiled from census data and does not undertake to show details. After that had been compiled then the question of the details of these different areas, details concerning the character of unimproved lands, was raised, and how such information could be displayed. The Soil Survey reports, so far as published, give details concerning the character, distribution and acreage of the various soils. For example, taking the report of this county, I can say, there are 967 acres of Orangeburg sandy loam in that county. The Soil Survey reports will show us, with great accuracy, the acreage of each soil type in the county surveyed. When a soil survey of a county is completed we have the data available in great detail. The reports will state further the approxinate percentage of any given soil remaining unimproved at the time the survey was made. That, of course, is an estimate, but is based upon the study of the man who went over the ground and saw every 40 or 10 acres of it. In fact, the Soil Survey man is supposed to see every foot of the ground. He does see the land so that he can form a very close estimate as to how much is cultivated and how much uncultivated. I took the survey reports therefore and compiled the data that they show, and that is shown in these charts I have here. I will begin with Alabama, the legend is placed up there.

In Alabama nearly every county has been surveyed in detail, so that we have definite data for every county except three. These are the counties of the coastal plain of Alabama, with the exception of two or three. The bars on the chart represent, by their length, the total acreage of unimproved land in each county, and these figures up here represent the number of acres in figures. The vertical red lines across all the bars cut them up into lengths of 100,000 acres each. You can see, therefore, that Baldwin county. for example, has 960,000 acres of land which is unimproved. Here in Lee County, for example, there is only 100,000 acres unimproved. 
That means 100,000 acres of coastal plain. Some of Lee County is in the coastal plain and some in the mountains to the north, so that the bar for this county does not represent all the unimproved land. The yellow color represents sand, the blue color, wer and heavy lands, the uncolored, the sandy loam, and the red color, the rough and mountainous lands. The wet and heavy lands include all lands wet, or frequently overflowed and all soils heavier than loams.

It is well known that sand has a certain adaptability to cropsthat is-there are certain crops which you can grow on sand, and certain others which do not do well on such soil. There are certain other crops adapted to wet and heavy lands-lands that have an abundance of moisture; and certain other crops are adapted to sandy loams. I will venture to say that the wet and heavy lands of the South are probably the lands on which stock raising will develop in the future the best, because they are the lands on which forage crops and grasses will grow the best. The sandy loam lands are lands wide in their range of adaptibility. They are well adapted to the growth of truck crops and cotton. Truck crops and cotton, then, are probably the best crops for the sands, forage crops for the wet and heavy lands, forestry for the rough lands, and general farm crops for the sandy loams.

It is not necessary to take up in detail each of the individual counties, but I will call your attention to certain general characteristics of the several states.

You will notice a considerable amount of yellow in the bars for the Alabama counties, showing the presence of a considerable amount of sand in Alabama. You will note also that the blue color representing the proportion of wet and heavy land is not extremely prominent. It is, however, in Clark County and Washington County. Practically all of this land in Washington County is wet land and not heavy. There is a large amount of sand in Baldwin County. As you go north, the sandy loam makes up a larger proportion of the soils. In the northern part of the state the clays represent a considerable proportion of the land, but it happens that all the clays are under cultivation and do not enter into this calculation.

Next I will take Mississippi. Another factor enters there, and that is lack of knowledge. We know much less about the soils of Mississippi than of Alabama, because only a relatively small part of the state has been covered by soil surveys up to the present time.

Sandy and Wet Lands; What They Are Adapted For. 
A solid colored bar represents a surveyed county, while a bar colored only in skeleton form represents an unsurveyed county where the proportions of the various kinds of lands given are based upon the character of the land in the nearest surveyed county, or upon the general knowledge we have acquired in our work in the state. We have gained more or less general knowledge of the character of soils in all parts of the United States, and that factor enters into this estimate.

Without going over the counties in detail, I will call your attention to the absence of yellow-the nearly complete absence-in the soils of Mississippi. In these counties lying in the southeastern and eastern part of the state there is some sand. In the western part of the state, not including the delta, the blue color, you will notice, is very prominent.

In other words, Mississippi is a state of rather heavy soils; that color represents both wet and heavy, but in Mississippi it represents relatively heavy land, with very little wet land. It is practically all silt loam. Mississippi is, therefore, a state of silt loams, Mississippi's well drained, as it happens in this case; a state, therefore, where Soils Largely the lands are adapted to forage crops. You will notice also that Silt Loams the percentage of sandy loam is rather lower than in the case of Alabama, but not so high as in Louisiana, for example. You will notice also that the red is more prominent in Mississippi than in Alabama. There are more rough lands in Mississippi than in Alabama, but a great deal of this rough land shown here represents silt land also. It represents land that can be converted into pasture.

You will notice again that Louisiana is not covered solid. We know relatively little about the details of Louisiana soils, except in a few places. We have surveyed Tangipahoa Parish in the east, Winn Parish in the northwest, Iberia in the southeast, East Baton Rouge, East Feliciana and Bienville, and recently surveyed Rapides, but the data for the latter is not yet available. You will notice that Louisiana the percentage of sand is low. The percentage of wet and heavy Rich in Sandy land is rather high. The percentage of rough land is also pretty Loams

low. The blue color is especially prominent in counties east of the Mississippi-Tangipahoa, East and West Feliciana. You will notice also the percentage of sandy loams-which is a widely adaptable soil-is relatively high. That, like the others, is based on estimate, of course, but the estimate is based on the general knowledge we have-a good deal of general knowledge and the results obtained by the surveys in the nearest surveyed counties. 
We have in Arkansas the whole of the state represented, except the lowlands, and it should be stated that the agricultural wealth of that state lies in its lowlands. I might say it is more or less of a misrepresentation of Arkansas to show merely its upland portion, a good deal of which is mountainous land, but you will notice the yellow is not present. You will notice the blue is quite prominent in a number of counties, but what corresponds to sandy loam in the other counties is quite prominent in Arkansas. That does not mean that it is all sandy loam, however. You will notice, though, that the red is quite prominent. Wherever we have a coastal plain county, there is very little red in it. Jefferson is a coastal plain, but the amount of unimproved land is larger than shown here, because not all of Jefferson County lies in the coastal plain, and is not represented here. Jefferson has a good deal of wet and heavy land. Grant County is a coastal plain county, and the proportion of rough and stony land is low. When we get into the mountain counties, the proportion of rough and stony land is relatively high.

Texas, again, we know relatively little about, and I have undertaken to show only the eastern part of the state. One of the characteristics of the Texas Coast Plain is that there is a very high percentage of sandy loam and a relatively low percentage of sand. One or two counties have a high percentage of sand. Wet and heavy lands are also low. Texas is a region of adaptable soils and a small amount of the characteristically forage land crops. I will also say that this blue color in Texas represents mostly the heavy lands, rather than the wet, for there is not a great deal of wet land in the state.

Now, to sum the whole thing up, I have put on the chart a summation of the data shown on the other cliarts.

This bar represents for Alabama the total improved land; this, the total unimproved land, and of the unimproved land, this represents the percentage of sand, this the wet and heavy land, this the rough, and this the sandy loam.

The same way in other states. You will notice here the large amount of blue in Mississippi and the relatively small amount of red-a little larger than in Alabama and quite a little larger than in Texas.

A Delegate: I would like to ask whether the chart represents the entire part of the states?

Mr. Marbut: No. It represents only those counties in the coastal plain, with the exception of Arkansas. 


\section{Some Factors to be Consid- ered in the Drainage of the Cut-Over I ands of the South $B y$ S. H. McCrory}

Chief of Drainage Investigations

Office of Public Roads and Rural Engineering U. S. Department of Agriculture

One of the fundamental requirements of any soil that is to be used profitably for agriculture is that it be well drained. It matters little how much inherent fertility the soil may possess, or how favorably located the land may be with respect to markets, if there is insufficient drainage agricultural operations cannot be conducted successfully. It is hardly necessary for me to

Two Kinds of Natural Drainage say that in all the Southern States there are large areas of cutover lands, which, before they can be made available for the practice of agriculture on a paying basis, must have existing drainage improved. These areas may be divided roughly into two classes. In the one class may be placed wide stretches of low-lying level lands with poorly developed natural drainage channels. In the other may be placed rolling and hilly land where the natural drainage is ample-if not too ample-only the narrow valleys along the streams needing drainage.

The low level lands are usually found in the coastal plain region or the Mississippi Valley. The drainage channels of these lands are usually shallow, poorly defined.depressions that vary in width from a few feet to several miles, and are generally covered with stumps and a heavy growth of small trees, brush, and vines. Occasionally there is a poorly defined stream channel that winds its way through the depression. Usually, however, the water finds its way slowly down the swamp through the trees and natural growth or stands until it sinks into the earth or is evaporated. Between the drainage channels are low ridges which usually rise only a few feet above the channels. The first attempts at cultivation are generally made on these ridges. During periods of heavy rain the water rises and the ridges become 
so wet that the growing or cultivating of crops becomes impossible.

The drainage of these low-lying level lands can usually be accomplished readily by the construction of properly designed drainage improvements. To design adequate drainage improvements the needs of each district must be considered separately. The first step is to make a survey of the lands involved. This survey should include a determination of the location, size and fall of the existing drainage channels, the relation of these channels to the area needing drainage, and the amount of land that will be drained by each watercourse. Sufficient elevations should be secured so that a clear idea of the character of the topography can be obtained. During the progress of the survey notes should be made of the vegetation, the character of the soil, and the apparent need of the various tracts for drainage. After the survey is completed a careful study should be made of the data secured, of the existing rainfall records, and of records of the amount of run-off from the areas in question or similar areas nearby in order to determine the amount of water that must be removed from the area which it is proposed to drain. Upon the proper determination of the amount of water that must be re-

How to Drain

Low-Lying moved depends to a large extent the successful operation of the drainage improvement. Many factors affect the amount of water that will be discharged from a given watershed. The principal factors are: Rainfall, topography, size and shape of the watershed, evaporation, climate and seasons, soil, geological structure, proportion of forest and open land, character of vegetation, natural reservoirs and artificial improvements affecting drainage.

After the amount of water that must be removed has been decided upon the proper size of the ditches can be readily computed by commonly known engineering formulx. In general the ditches should have ample depth. For dredge ditches eight feet is probably a minimum depth under ordinary conditions. The excavated material should not be placed closer than eight feet to the edge of the ditch and if the ditch is very deep the distance should be much greater.

The drainage ditches should be so located that they can be readily reached by the landowners whose lands they are supposerl to benefit. The topography of the district and the character of the farm drains that will be used are usually the deciding factors in determining the location of the ditches. 


\section{Drainage in} Hilly Country

Timber

Removal and Erosion

I come now to the problem of successfully draining the narrow stream valleys in the hilly country. This can be accomplished only by coupling drainage with measures to prevent and control erosion on the surrounding hills if the improvement is to be permanent and satisfactory.

When the rolling and hilly country in the entire watershed was timbered and in its natural state, the drainage system was well developed, and only the narrow strips of low lands found along the streams needed drainage. With the removal of the timber on the hill lands and attempts at cultivation of these hills, the forces of nature began to work and soon erosion developed with the result that the streams in the lowlands were filled with soil washed from the hillsides and the bottoms were flooded so frequently that they were abandoned. A description of conditions in a typical area before drainage will give you a clear idea of the lands I have in mind:

"Beginning at the northern extremity, the channel is very narrow and crooked, though its general direction is straight. The depth of this section varies from one-half to 1 foot. Near its mouth the stream is much wider, averaging about ten to fifteen feet, and in a better condition. The entire length of the stream has a heavy growth of brush, trees, and logs.

"Not much meadow land is found along the stream, the width between the hills varying from about 100 feet to one-fourth mile, being as much as one-half mile in only one or possibly two short strips. Practically all of this land has at one time been under cultivation, and years ago, when the stream had a much deeper and better defined channel, large crops of corn and hay were produced. However, the landowners have been cultivating their hill lands almost entirely with cotton, corn, or some other clean crop, year after year, giving little or no attention to the care of the hillside wash, until today over three-fourths of this low land is practically valueless. Several of the landowners stated that about twenty-five years ago the channel was from four to six feet deep, while today, except where improved, it will not average over one to two feet in depth, being filled with the hillside wash. Overflows are frequent on this stream; although some of them are quite large, especially the spring and summer freshets, very little damage can be done at present since none of the landowners attempt the cultivation of this low land."

How shall these hilly lands and narrow lowlands be conserved? As in the drainage of the low-lying lands, so in the drainage of these hill lands, the first step is to make a survey of the stream valley similar to that before indicated. Frequently 
it is found advisable to construct a new channel which should be located usually down the middle of the valley. Rock is frequently found in these valleys and hence it is essential that sufficient borings be made to locate any rock that might be encountered in constructing the ditches. Experience has shown that by carefully determining the location and area of rock ledges the ditch can be so located as to avoid them.

The amount of water removed by these streams is so large that it has not been found economically practicable to prevent entirely the overflow of the bottom lands. The amount of runoff that must be provided for on these streams is considerably more than that on the low-lying level areas. Satisfactory results have been secured in reclaiming bottom lands draining from 35 to 50 square miles when the ditches provided for one inch in depth in twenty-four hours over the entire watershed. On other streams a somewhat lower rate of runoff has been used with quite satisfactory results. The most important factor seems to be to have the ditch as deep as possible so that during periods of low water in the ditch the bottom can be thoroughly drained. The overflows that occur after the ditch has been constructed are usually of short duration and many landowners believe they are benefited more by the deposit of silt on their lands than they are injured.

The period of usefulness of ditches constructed in these valleys will depend largely on how successfully erosion on the hillsides is controlled. Control the erosion on the hillsides and you perform a double function; namely, the conservation of the fertility of the hill lands and the extension of usefulness of the ditches in the lowlands. It has been amply demonstrated in this country and abroad that erosion can be controlled by improved methods of agriculture and the use of terraces. Successful examples of terracing can be found in every Southern state. Construction of ditches in the lowlands without proper attention to the hillsides means excessive and frequent maintenance costs if the ditches are to be kept in good working condition.

A word on the subject of costs. Drainage improvements for low-lying level areas range from $\$ 2$ to $\$ 10$ per acre. In the narrow valleys the cost ranges from $\$ 15$ to $\$ 50$ an acre. These costs are for outlet drainage only and do not include the cost of draining the individual tracts or of terracing the hill lands. Neither do these prices include clearing of the lands.

\section{Best Methods} to Follow 
I have outlined in a general way the character of improvements needed to drain cut-over lands. I have indicated the range of cost to construct proper drainage systems. The question whether these lands should be drained resolves itself into the simple business proposition: Will it pay? To answer this question properly consideration must be given to suitability of the soil to producing crops adapted to the region, transportation facilities, markets, cost of clearing and developing, demand for more agricultural land, and desirability of location for settlement. In cases where drainage is undertaken principally with a view to selling the lands rather than to opening them up to cultivation by their owners, care must be taken to see that such settlers have sufficient funds to clear and develop the land, plant it, and to provide for their needs until they can realize something from their crops.

It will be of interest to refer for a moment to some sections where cut-over lands have been drained and see what has followed drainage. Not so long ago from a landowner in a 200,000acre tract of low-lying level land in Arkansas we received a letter reading in part as follows: "Many thousand acres of land have gone rapidly into cultivation, with population and production increasing amazingly. Many hundreds of houses and barns

High Productivity of Property Drained Cut-Over Lands have been built per annum for the past several years. Lands that were in swamps and timber a few years ago have lately been producing 75 to 95 bushels of corn per acre and this year $\$ 75$ to $\$ 125$ worth of cotton per acre; and miles of good roads where were swamps and cut-over timber. Certainly our efforts and expenditures have been justified beyond all expectation." On similar land in Missouri the farmers have reported harvesting 28 bushels of winter wheat the first year and from 35 to 45 bushels of corn. A few years ago the hilly and narrow lowlands of which I read you a description of conditions were drained. Not so long ago a landowner in that section remarked that the value of the corn crops harvested the first year after drainage was completed was sufficient to pay the entire cost of drainage.

There is another form of benefit accruing from the drainage of swamp and cut-over land, which, though not tangible or capable of being expressed in dollars and cents, should not be overlooked. I refer to the influence of drainage on the sanitary conditions of the community. Not long ago I was inspecting one of the first drainage ditches to be constructed in the Piedmont Sec- 
tion of North Carolina. While on this inspection I chanced to meet an old lady at a farm house. During the conversation I inquired regarding the health of the community. To my inquiry she replied with much satisfaction that for the past two or three years they had practically no sickness, but that prior to that time every summer and fall they and all their neighbors suffered much with "chills and fevers." When I recalled when the Drainage Improves Sanitary drainage was completed, I found that the sickness to which the old lady referred abated just after the time the improvements were completed. The experience related is only in common with that experienced by many in other sections where cut-over lands were drained.

From the benefits which I have enumerated as being received in certain sections I do not wish it to be inferred that the drainage of any and all cut-over lands is to be encouraged. The soil in the sections to which I refer was of unquestioned agricultural value and the lands seemed to combine in unusual degree all the factors which I have previously indicated must receive careful preliminary consideration before drainage is undertaken.

In conclusion let me leave with you this parting word: If it is the purpose of this association to encourage and promote the drainage of the cut-over lands in the South, see to it that projects are undertaken only after careful, discriminating consideration is given to the various factors I have endeavored to impress upon you. Remember after all, if the drainage of these lands is undertaken on anything other than a sound business basis in the end it must prove a disappointment if not a failure. 


\section{Some Problems of Cut-Over Land Development}

\section{By Harry D. Wilson}

\section{Commissioner of Agriculture of the State of Louisiana}

Cattle Importations from South America Opposed
Right Sort of Colonists Must Be Obtained $\cdot$

Mr. Chairman, Ladies and Gentlemen :-As I am a real hillbilly, born and raised in the cut-over section, I really think I know something of the cut-over proposition; but before I start on this subject I want to say that I cannot fully agree with our brilliant Governor from Arkansas in reference to throwing open the bars to the importation of cattle from Argentine and other countries. (Applause.) I want to say, gentlemen, that we are fighting day and night to get rid of the cattle tick. We want to get rid of what we have, before we bring in any more to work on.

This thing at first glance may sound all right; but we don't know so much about this cattle business. We want more good cattle, but if we want to develop these cut-over lands we better go slow on this proposition. You know, I am a Louisiana Democrat, and that means that we like to protect our agricultural interests, and we are getting away from the idea of free trade. If you don't make the conditions surrounding that boy and woman on the farm as interesting as those surrounding the fellow in the city he won't stay. He can't get along competing with negroes and Japanese raising cattle on lands that don't cost anything. My opinion is that these cut-over lands have a value to them.

The success of this great enterprise that you gentlemen have under consideration today depends absolutely on the people you put on these cut-over lands. I want to sound a note of warning. If you folks bring down people from the North or from foreign countries that are farmers, they will succeed; but if you bring shoemakers and blacksmiths and street car conductors, the result will be disastrous; and we want these land's settled by people that will stay.

We have a great industry that I am particularly interested in-the sheep industry. We have not as many' sheep in the whole United States as we had forty years ago; but there is one 
trouble to that industry, and that is the dog. Now, mind you. I never saw a man who had a sheep-killing dog in my life; but you cannot have sheep and dogs in the same county or parish. The Legislatures have to take care of the dogs, so we can have sheep. I have no objections to a dog, but I do have objection to a dog killing my sheep. If we can regulate the dog-there are no sheep-killing dogs, I know-but if we can regulate the dog in some way these cut-over lands can be, brought up to their economic limits at once. You don't have to remove stumps to graze sheep; they will do your cultivating without the removal of stumps; but when you go out to plowing, some of us are cultivating the same stumps that our grandfathers left. You have to get those stumps out, because you can't farm on it with stumps. Now, the question has often come to my mind, since this great convention was advertised for' New Orleans, whether it is more economical for the large lind owner to cut those stumps out and put the land in perfect condition, or whether it is best for the forty or sixty-acre farmer to do it. That is something for a man higher up to solve than a common two by four Commissioner of Agriculture.

Now, gentlemen, I want to warn you all of this: Don't go too fast in some wild-cat scheme. The foundation of this whole problem is to get people that will stay-not any fly-by-night concerns. What we want is something permanent. If you bring some farmers down here and 95 per cent of them go iack up North, they will tell them up there that this is a devil of a country. But the best advertisement in the world is a satisfied customer.

If you just get down to the proper ideas of business methods you will find there is a world of virtue in these cut-over lands. It is very susceptible to drainage, and it is very susceptible to any good treatment you give it. Soy beans is one of its best crops; and soy beans and velvet beans will soon put these lands where they will be just as fertile and raise just as good crops as these alluvial lands. I do hope something tangible and businesslike will come from this great Conference; and you can depend Development Must Be on on the Department of Agriculture doing everything in its power to back up and foster and push forward every movement. On the other hand, if there is any disposition to try anything not just right, and it comes to the notice of the Department of Agriculture, we will put our stamp of disapproval on it ; for you cannot get by but once with deception. Now, the Department of Ag-

Destroy the

Sheep-Killing

Dog 
riculture will do anything in its power to help any land company develop this on a sane, conservative business basis. I thank you. (Applause.)

\section{The Forage Problem of the Coastal Plain Area \\ By Dr. C. V. Piper}

Chief Agrostologist, Bureau of Plant Industry, United States Department of Agriculture

One of the joys of my life is to listen to an ardent Californian describe the attractions of his wonderful state. If he is a little enthusiastic, his description is like that we are inclined to associate with Paradise; and he is not so very wrong, after all, even if portions of California are more nearly comparable with another place. I have listened to very many able addresses in which the resources of the Southland were described, but when the enthusiastic Southerner is describing the South he is never thinking of these cut-over pine lands. He is thinking of some other part of Dixieland.

Now, gentlemen, we are here to discuss the most important large land problem in the United States, certainly the most important of possible agricultural lands. I want to make it clear just what lands I am talking about in my address. We heard from Dr. Marbut this morning as to the classification of these lands. In the Coastal Plains there are large areas of alluvial and swamp lands, which, when well drained, present no serions problem to agriculture. There are other areas of very sandy lands which do present a serious problem. Intermediate between these are large areas of land lumped together as sandy loams, and, for the most part, in the area we are discussing, well drained; those are the ones my remarks will apply to particularly. If we can utilize those lands successfully then there will be ample time to take up the more difficult sandy areas.

Now, gentlemen, there is no question but what these lands are not sufficiently fertile. If they were fertile lands they would have been utilized long ago; but they have not been attractive 
from the viewpoint of the farmer. It is well known, however, that any of these sandy loam lands, when well and judiciously fertilized, will produce good crops. Under present economic conditions, however, no large body of these lands can be utilized in that way. When the population of the United States is double what it is today, all of the land will probably be developed into small productive farms. In the meantime, what are we going to do about it?

The crying need, fundamentally, is to find in the near future some profitable use for these lands, and one of the lines along which it seems that use can be made, under present economic conditions, is the growing of live stock, particularly cattle and sheep, which utilize large areas of land.

Now, at the present time there is already a live stock industry on these cut-over pine lands. It is the live stock industry of growing razorback hogs and piney woods cattle, an industry that long ago reached approximately the limits of its practical development. The problem is, can we replace this type of industry by a more attractive and more profitable one? I think you will agree with me that if we are to have a profitable live stock industry on these lands, the keynote to the entire subject will be, can we grow the forage on these lands; and it is about the forage question I am to speak this afternoon.

I want you to look for a moment at the few maps I have. This first map indicates the production of hay and forage in the United States in 1909, according to the last census. These dots, representing 10,000 acres each, are very accurately placed, just as accurately as it is possible from statistics. Notice where the hay and forage is grown. You will see that it is largely in the 11ortheastern quarter of the United States. Of course, in the West there is a great deal of forage not shown on this map. I refer to the native pasture and range land. In the same way, the native forage of the South is not indicated on this map. The map indicates forage crops only on cultivated land.

The statistics of corn are not included in the forage, but separately, although practically all the corn is fed to animals. All the corn is in the eastern half of the United States; but considerably more than half is in the northern part of the eastern portion of the United States.

Now, you would naturally expect the distribution of live stock to be correlated to that forage. Notice on this second map

More Forage Necessary to Better Cattle 
where the live stock is-the great black area in that northeastern quarter of the United States. It is perfectly obvious that forage and live stock go together.

I said that these cut-over pine lands are not generally fertile, but can be made to produce large crops. This is being done in many areas throughout the Coastal Plains on soils essentially the same as the sandy loam soils I am speaking about, but when it comes to growing forage which is cheap crop, any large use of fertilizers is probably out of the question. The increased fertility will in the main have to be brought about by indirect methods. I want to state frankly that in the light of our present knowledge it is out of the question for the Department of Agriculture, and I believe for any of the State Experiment Stations. to recommend farmers to engage in the live stock industry on these areas on these cut-over pine lands. The reason we cannot conservatively recommend that is because the necessary data do not exist. We have scattered amounts of data obtained from small experiments; we have a small amount of experience from practical stockmen-but a very small amount. In all the area I am talking about there is not, to my knowledge, one modern live stock farm where the possibility and practicability of profitably producing cattle and sheep has been demonstrated. Without that demonstration we have to be very cautious. While I state this with all frankness, I want to add to it my own opinion as to the possibilities. I have no doubt that by the judicious use of the knowledge we already possess, profitable cattle and sheep raising can be carried on on these Coastal Plains sandy loam soils.

If we do not already have this demonstrated knowledge

Need of Experiment Work
Two Methods to $\mathrm{Be} \mathrm{Fol-}$ lowed that I have mentioned-and we do not have it-how are we to get it? There are just two methods: One is to await the experience of men patriotic enough to go into the cattle or sheep business. After the course of years, through their success or failure, we will gradually learn the possibility of these lands from the live stock point of view. A few enterprising men and companies have already gone into such ventures; but this way of obtaining knowledge is long and costly, and usually it is not readily accessible to the public.

The other method of obtaining the knowledge is by establishing properly equipped live stock and forage experiment stations, where in the course of a few years we ought to be able to 
tell just what is possible on these lands in the way of profitable live stock industry. In my judgment, this latter method is by far the better and more economical.

I have already stated that my own opinion on this whole matter is optimistic. I want again to caution you that opinion and demonstrated knowledge are two radically different things. I would not hesitate to give any man my opinion but I would also caution him that it was my opinion and that there was no place he could see the thing demonstrated at the present time.

I want to go into some details as to the facts on the raising of forage on these lands which lead me to have optimistic opinions. In the first place, various forage crops can be grown profitably on these lands, and with a very moderate amount of fertilizers, if any. Among summer crops are peanuts, velvet beans, beggarweed, and soy beans-all legumes. For winter crops oats and rye can be grown with a high degree of success, and where the land is more fertile you can bring in bur clover and vetch. These crops all require the fitting of the land each time they are planted, and will probably repay the use of a relatively small amount of fertilizer. In the way of perennial forage crops we have Japanese sugar cane, that will raise more tonnage

Abundant

Forage Easily Grown on Cut-Over Lands per acre than any other crop similar to it, and when once established it is good for from six to twelve years without replanting. It is an excellent silage plant, and abundantly repays any use of fertilizer.

Another perennial forage crop which I believe is going to cut a large figure in the utilization of these lands is the perennial legume kudzu. At Arlington Farm, we have been able to raise in each of the past three years over five tons of kudzu hay per acre, double what we could get from cow peas. It prefers apparently a clay subsoil, but I have seen excellent growth of it on sandy loam. Then there are various other forages you can grow on these lands as soon as you have built up the fertility a littlecorn and sorghums, millets and various other plants.

The real forage difficulty is the pasture problem. You cannot conduct profitably any animal industry on a large acreage without the use of permanent pasture. Now, the permanent native lasture on these piney woods lands consists of broom sedge and various wiry grasses, which may be grouped under the name of wire grass. These grasses furnish very poor feed. For two or three months in the spring they give fair pasturage; after that 
they are the poorest type of pasture, and just the ordinary type of pasture that the piney woods cattle subsist upon.

There is one striking fact, however, in regard to pastures in the piney woods which can be seen in the vicinity of every town and village in the South, and that is that wherever the town cattle graze continuously, you get patches of very dense sod consisting mainly of carpet grass.

We know that heavy grazing is an important factor in the bringing about of this type of pasture. Where the cattle graze continuously you have carpet grass, elsewhere broom sedge and wire grass persist. Ordinarily, it requires heavy continuous pasturage to kill out wire grass and to secure carpet and other desirable pastures grasses. But when you once have good carpet grass you can allow it practically to take care of itself.

In it may come the growth of more or less Bermuda, but there is not much of it as a rule. There is usually a good deal of Lespedeza, however. In winter the pasturage is supplemented, to some extent, by Bur clover, and large quantities of this can be brought in. The carrying capacity of a good carpet grass pasture is not very well known, but it seems to me it is not

Types of Grass Best Snited

\section{South's} Agriculture Distinctively American much different from the blue grass pastures of the North. I believe, in general, a good carpet grass pasture will carry one cow to about three acres. The best blue grass will carry one cow to two and a half acres. Your pasture season for carpet grass is much longer than for blue grass, and will be eight or nine months of the year. In the light of our present knowledge, this is the only type of good permanent pasture that you can look forward to on these sandy loam soils. I may say, incidentally, that carpet grass seed is not a commercial seed, but almost any place in the South where you pasture heavily the carpet grass will gradually come in.

In this connection I want to mention one factor which is likely to be enormously important. Generally speaking, the agriculture of the North was a direct inheritance of the agriculture of Europe. The only important crop exception is corn. When you come to the South the situation is entirely different. The agriculture of the South is almost entirely American. We have inherited cotton, corn, tobacco, peanuts, sweet potatoes from the American Indian. We have gone to Japan for the soy bean and Japan clover; to India to get Bermuda grass; to the Malayan region to get the velvet bean; to Africa to get cow peas and sorghums; to 
India for sugar cane; in other words, we have built up the agriculture of the South from crop plants we have obtained from all parts of the world. That is particularly true of the forage crops. Every forage crop we grow in the South is introduced. We have been unable in agriculture to utilize a single native plant of the South.

When you bear in mind that there are in existence some ten thousand species of legumes, and four thousand species of grasses, it must be evident to you that there are still large possibilities in finding other valuable forage grasses or legumes. This is a subject which demands very exhaustive investigation. In a relatively small way we have been doing this in the Department for years and with some success. At the present time we have under trial a number of recently obtained forages, which possess various degree of promise; and some of these, I am sure, are going to make easier the forage problems on the soils we are talking about.

I might mention some of the plants that apply to the South. One is a native of South. Africa, where it has created a great deal of interest, and is known as "Napier's Fodder." It is a perennial grass, growing in the manner of sugar cane, and produces a very large amount of highly palatable feed per acre. In some of the Coastal Plain states it has succeeded very well.

We have also been investigating very carefully the different varieties of Bermuda grasses, and we have found one that gives double the yield of ordinary Bermuda. Whether that will be the case under practical pasture conditions remains to be determined.

I might mention a lot of these legumes and grasses; but I will say that out of the enormous number of legumes and grasses available we have found several that are going to help solve this forage problem in the South. I stated a moment ago that all the forage plants we are growing in the United States are introduced. This is as true in the North as in the South. The pasture plants throughout that area are blue grass, white clover and red cloverfrom Europe. The hay plants are timothy and red clover, from Europe, and so on down the line. Qut of the enormous agriculturally unexplored areas of the earth may come very much more.

But altogether apart from these possibilities which lie in the iuture, my opinion, as I have stated before, is pretty optimistic. I believe that with our present knowledge we can build up a prof- 
Impracticable to Combine Cattle Raising and Forestry

Confident of Ultimate Success of Work

itable live stock industry - the cattle industry I am thinking of, particularly. When it comes to the hog industry, I think it has already been demonstrated in these sandy loam areas that by the use of peanuts, velvet beans, soy beans and others, you can conduct a profitable hog industry; but this is a relatively intensive type of farming as compared with cattle raising.

The question has been brought up a number of times as to what extent live stock farming in the South, particularly cattle raising, and forestry, may be conducted together. I do not think, myself, that the idea is very feasible. Over most of these sandy loam soils if you don't burn the woods every year or so it comes up thickly in young pines. If you do burn it, you get your grounds cleared, but of course, you burn off your second growth. One gentleman, a few years ago, complained about the number of young pines that grew up in his pasture, and he wanted to know what to do. An expert advised him that they were very good pasture for piney woods cattle. He wanted to know the advantage of them. The expert replied: "Well, you see, the cows eat more or less of those young pines, and the effect of it is to shrink their stomachs, and therefore there is less danger of the cow starving to death." (Laughter.)

Now, I want to recapitulate briefly and emphasize the main points of this problem. So far as growing reasonably large crops of forage on these sandy loam soils, using a judicious amount of fertilizer, there is in my opinion no question. There is a pretty serious problem as to how practicable it is to take poor broom sedge and wire grass pasture and gradually convert it into good carpet grass pasture. I don't know how it can be speeded up. We need investigations, very seriously on that particular point. We don't know, after the carpet grass pasture is obtained, just how well cattle are going to succeed on it. There is reason to believe, however, that the results will be satisfactory. But it will be necessary to supplement this by some other feed. However, that is commonly done in the North and other pasturing regions.

I want to close by saying that in general the whole situation of the live stock enterprise, at least from the standpoint of growing the forage crops, looks to me decidedly optimistic. I want to repeat again that until we have demonstrated knowledge to show this to be a fact, we cannot conscientiously advise farmers to go into this thing unless they understand fully that certainty of 
success is as yet unproven. What we need most, in order to get the knowledge really required, are these live stock and forage experiment stations, which, in my judgment, present the simplest and cheapest plan to get the information we need and ought to have. I thank you. (Applause.)

\section{Experiences in Cattle Raising on Cut-Over Lands}

\section{By F. B. Enochs of Fernwood, Miss.}

The first venture we made in the cattle business, I bought a registered bull on the 13th day of February, 1913. Before that I didn't know how to raise any pedigreed animal intelligently. My cndeavor was then to breed up some of my native cattle. We bought considerable native cattle through the country. We made a mistake-and I want to be frank with you on that-we didn't appreciate the fact that this in-bred class of cattle, that had been in-bred for ten years, of the dairy type, were practically run out and would give us poor results; but when we picked the best of those and began to put pure bred bulls on them to breed them up, we got about the same results as when a man gets a good stallion and breeds him. We have an improvement. Now, those calves that we got, they had a good front and rear end, and the dairy type didn't have that. They were the other extreme-all points. We went into the cattle business under difficulties. We had to pioneer. Certain people in this audience will know that we dipped cattle two years before we could get our county to vote to get rid of the tick, and we had to convince them that dipping cattle would not kill them. After dipping that same bunch of cattle for two years we finally got a vote in our county of 81 per cent of the registered voters; we only had 19 per cent that voted against it. We have gotten through with that end of it and we have gotten rid of the tick, as a result of the

Tick Eliminated as a Factor pioneering we did in the early history of our cattle endeavor. We have gotten round the fact that we have been going in for pure bred, for the simple reason that there are people in Mississippi that have to be educated to buying good bulls, just like I did; I didn't

Early Mistakes in Grades of Cattle Selected 
know any difference between a good heifer, even if she had a register paper, and a poor heifer.

Most people concede that you can take a human family of ten and you can find a black sheep among them. We shipped to Oklahoma this spring, with our herd of show cattle, some Herefords, and they sold for an average of $\$ 300$, and they were not yet breeding age. We sold some Herefords in Ft. Worth, Texas, for as high as $\$ 450$, not yet of breeding age. That is our pure bred cattle. At the this year's sale in Jackson, Miss., we sent three heifers and one bull up there that really we ought not to have sacrificed-that we ought to have kept. We took them up there to help out the sale, and they sold for from $\$ 175$ to $\$ 195$, and most of them were April calves, 1916. Now I don't know a man in Missouri but what is willing to sell a year-old mule for less money than $\$ 175$. The disadvantage we were under was that we didn't know the stock business. We were green at it when we started; as green as could be. Why? We were lumbermen. We had been engaged ever since we were boys in running a sawmill and other lines of endeavor; but the position we took was this: Looking forward to the time when we are cut out, that settlement will be a desert sawmill settlement unless we do what we are doing there, and that is to es-

Success

Comes With

Knowledge

Abundant

Forage Crops Produced tablish the cattle business. The most good fortune I have had is to find a man who knew how to handle that cattle business. I spent more money advertising for a man to take care of that department than any other department. When I got a man from the North he didn't know Southern conditions, labor and rainfall. He didn't know winter conditions liere, and we have gradually had to take those that came to us; but today, in my judgment, I am not sorry I went into the cattle business, and if the State of Mississippi and the Southern States will get around this point on these lands-that they get rid of this in-bred class of cattle and grow some good cattle to put into the feed-pen-it will give you some return for your feed. The class of cattle called the "scrub" isn't going to give you any return for your feed. We have built silos and filled them to the extent of 2,700 tons of ensilage in one year. We have not only corn ensilage, but we have grown as many as 14,000 bushels of oats in one season. We also grow lespedeza. Professor Lloyd was there three years ago and he said he didn't know the cut-over hill soils of South Mississippi would grow lespedeza after oats. It was an enlightenment to him. 
The bur clover was not already on these lands. We have had all the misfits coming to us working against a proposition that didn't look good to a lot of people, and yet we have sold our calves at less than two years,old for the price of three-year-old mules in Missouri. Under circumstances of that kind, I have been told that whenever you try to make a man do something he don't want to do, it is an uphill business to push him on.

I am in the game to win and I believe we are going to win: and I am a little disappointed to hear some of the discouraging reports here; because I was raised in this same territory and I feel that a man can make a living here. My father, a farmer, raised ten boys and a daughter on this rery land that everybody is trying to find somebody to buy.

Dr. Piper: How many acres of ranch have you?

Mr. Enochs: About 7,000 acres. Not ranch-but cut-over stump lands fenced.

Dr. Piper: How many pure bred cattle?

Mr. Enochs: One hundred and thirty.

Dr. Piper: How many native?

Mr. Enochs: Possibly 1,600.

Mr. L. D. Gilbert, Texarkana, Tex.: How many acres of Ten Acres Sufficient to Graze a Cow land are you using to graze those?

Mr. Enochs: We are not grazing as many cattle as we did. We have about 7,000 acres and as we get good grade heifers we turn common old cows loose, because we would rather have a iess number of grades and breed them, than to keep the common scrub-breed proposition.

Mr. Gilbert: Are you running all of your cattle on your pasture or on the open range?

Mr. Enochs: We don't ever put them on the open range because they go astray, and we don't get them. As a protection to that we have three brands on them and keep them under fence.

Mr. Gilbert: How many of them, approximately, are you running on this 7,000 acres?

Mr. Enochs: Our ownership now is 1,600 grades and 130 pure bied, but we don't need that 7,000 acres for them. We figure ten acres will easily graze a cow: That is what you are getting at, isn't it?

Mr. Gilbert: Yes.

Mr. Enochs: We have grazed a cow on less than ten acres, but we don't do it as against the extremes of the season. We have 
Lespedeza

Solves Pasturage Problem

had favorable seasons in which we have grazed as low as five acres, but we wouldn't do it when we have the extremes of the season.

Mr. Gilbert: On a ten-acre basis that would only carry 700 .

Mr. Enochs: Well, we have rented some of these grazing areas that other people are not willing to put cattle on. You asked me how much we had.

Dr. Piper: You run ten acres to the cow?

Mr. Enochs: Yes.

Dr. Piper: Is that the ordinary piney woods pasture?

Mr. Enochs: That is the ordinary piney woods stump land.

Dr. Piper: Is that pasture improving under your system of pasturage?

Mr. Enochs: Yes, sir. It is going to lespedeza now. Before that, the fires would destroy the lespedeza and then we only had the wire grass, but now the lespedeza is gradually getting hold of this land, and the cattle graze it close enough so there is little chance for broom grass growth.

Dr. Piper: Is the carpet grass coming in, too?

Mr. Enochs: Some, but not so much on hillsides. They do on these flat lands that don't get the water off. The flat lands are what we call top table lands. IVe don't consider we have made any money on the proposition, but we were in the business possibly three years before we saw a profit, because we didn't know the line.

Dr. Piper: How many acres of feed are you growing to an animal?

Mr. Enochs: That is hard to answer, because we are feeding $\log$ teams and turpentine teams out of the same enclosures.

Growing Feed

Dr. Piper: You are growing an ample amount, evidently, to for the Cattle supplement your pastures?

Mr. Enochs: Well, not in the sense of the man in the North, because a man in the North frequently, when a dry spell comes, has two or three silos of ensilage to supplement his cattle in the summer grass growing season, when the hot sultry suns burn up the grass. We have not gotten around to the point that we have been able to carry everything. We went most too heavy on cattle for the experience we have. 


\section{Soil Improvement Crops \\ $B y$ S. M. Tracy}

Agronomist, Office of Forage Crop Investigation, United States Department of Agriculture

Mr. Chairman and Gentlemen :-Mr. Piper gives a long list of forage crops which can be grown successfully and profitably here on most of our Southern soils, but before we can grow those crops we must have something on which to grow them. A good crop of grass, of legume, of corn or of anything else has to have a foundation; it has to have something on which to live. We have many good soils in the Pine Woods country, but all soils, wherever they may be located, can be improved, but we must learn how we can make our poor soils good, and our good soils better.

Our pine soils, as a rule, are very deficient in humus. We must supply that first. When that is supplied we may go out after much more profitable crops that we can produce on our cut-over lands. Humus is the first essential thing in soils. We can add nitrogen, if you want to, but without the humus, the decayed vegetable and animal matter, you are bound to be disappointed; you will suffer from drouths and floods and your crop will not be what you had a right to expect. The average pile of bricks has enough phosphoric acid and potash for a good crop. But you have to have some humus to hold that soil in the condition in which the plants can assimilate it. The soils of our pine woods lands, both the cut-over lands and the virgin timber lands, contain very little humus.

Humus Must Be Restored to Soil They have been burned year after year, generation after generation, until the humus is thoroughly destroyed; all of the available nitrogen driven off, and they are in a condition where they produce anything but desirable crops. Every burning we give to a pine woods, or wild lands of any kind, destroys more humus and nitrogen and exhausts the soil more than does a crop of corn or cotton. The fire is the most expensive crop we have. Soil is far from being enriched by burning; it always makes it poorer; and before we can get the crops which are our due we must restore the humus to the soil.

Pound for pound, the dry matter of all plants will produce about the same amounts of humus. So far as is known, the value 
of the humus is the same no matter from what particular plant it may have been derived. That being the case, the plants which we want to grow for our humus are those which will give us the greatest number of pounds per acre.

The desirable humus crop is one which will grow rapidly and make a heavy yield, which will decay quickly, and, if possible, one which will not.only provide humus but will also absorb nitrogen from the air and so give us that most expensive element in commercial fertilizers. This is the ideal type of humus producing plant; and we have such plants in the legumes, plants which draw

Taming Wild Soils

Velvet Bean the Ideal Legume their nitrogen from the air and which are equal to any others in providing the humus. Mr. Piper said we had something over ten thousand species of legumes. Out of this ten thousand we have cultivated perhaps a couple of hundred, so you see we have barely touched them. They have an infinite variety. We have some which grow very large, and some slender, and some in bushes and some on vines, and some are short straggling plants. Some grow in winter and some in summer. In that group we can get some species which will fit almost any desired condition or farm.

It is a recognized fact that on most of our pine woods soils we do not get as good a yield of corn, or of cotton, and some other crops, the year in which the land is cleared as we do a year or two later. The soil is in a condition which has produced a certain type of wild plant for years, and it must be greatly changed in its nature before we can expect it to produce a good yield of ordinary cultivated plants. We must have something to civilize the soil, to tame it down, before we can expect our tame, civilized crops to feel at home.

We have one legume eminently fitted for this-the velvet bean. It will do more than any other crop we have ever had to smother the wild growth. It will furnish more humus than we can get from any other crop. It is a rank-growing vine, and can be grown in any part of the pine woods country. It has almost universal possibilities, and will certainly grow in all of our cut-over pine region.

It was in 1898 that the Department of Agriculture first called attention to these beans as an agricultural product. They had been grown for a great many years before that in Florida simply as an ornamental vine; but in 1898, in one of the publications, it was mentioned as being a very desirable forage. At that time we knew of only one variety-what is now known as the "Florida Velvet Bean." That is seldom seen outside of Florida, and although it 
was frequently planted in other regions it didn't become popular because they always had to send to Florida to get the seed.

Twelve years ago the Department took up the matter in a systematic manner and began a careful search of the entire world, trying to find other species of velvet bean which would be more hardy and mature earlier and have other desirable characteristics lacking in the Florida bean. Up to this time about twenty distinct species have been brought in. Of these, some hundreds of hybrids and crosses have been made in an endeavor to combine the desirable qualities of the different species; and now we have an infinite variety, and of these quite a number of forms have made for themselves a place in the agriculture of the South.

The old Florida bean was a vine which grew pretty high; I don't think any of us know how long it will grow; it produces a small pod $2 \frac{1}{2}$ to 3 inches, with small mottled seeds, the pod covered with a black velvet-from which the bean took its name. Until twelve years ago that was the only variety we had in cultivation.

Another was what is known as the "Lyon" bean. The pod, instead of being three inches long, was nearly six inches in length; the beans, instead of being spherical and mottled, were large, flattened ovals, like a butter bean, only larger. The pods, instead of being covered with black, velvety pubescence, were covered with grayish hairs and of quite a different form-pointed at each end. If anything, it was more rank growing than the Florida bean, and produced fully as heavily, but unfortunately ripened very little earlier. These were popular for two or three years until we got others in.

The next was what is known as the "Yokohama" bean, from Japan. That pod is very similar to that of the Lyon bean, a large pod with ash colored or white seed, the pod covered with hairy bristles instead of velvet. The vine is rather small. This ripens in about five months from planting, where the old bean took nine to ten months.

Following that came the "Chinese" bean, which is probably little more than an early ripening variety of the Lyon bean. That ripens in a hundred and fifty days from planting.

Then we have another one, which came to us probably from Georgia; it is called the "Georgia" bean. Some say it is a 90 and 100 -day bean, but it is not; it ripens in 120 days. The pod is very similar to that of the Florida bean, but the vine is much smaller.

Early Varieties of Bean Development 
Then we have another one of the hybrids, called the "Osceola" bean. That is something between the Lyon and the old Florida bean, and was produced by the Florida Experiment Station. It has the black, velvety pod of the old Florida bean, but has a very much larger seed; nearly as large as the Lyon, or Chinese, or Yokohama.

In general, the varieties having the large, black, velvety pods have one characteristic which is very desirable-the Lyon bean, the Chinese bean and the Yokohama bean, those large hairy-podded ones, very often split open when they are growing on the vines and beginning to get ripe. The black, velvety pods do not split open, and therefore are somewhat better.

For the extreme South, the old Florida bean and the Lyon bean are among the best we have. From here north to central Mississippi or Alabama the more productive beans are the

Best Beans for Different Localities Osceola and the Chinese. Still further north to Tennessee and in Georgia the Iokohama and Georgia beans will be found more satisfactory. We have so many of these varieties now that we can find something which is suited to practically every locality where velvet beans may be wanted.

We do not need to discuss the varieties here extensively, because they will be more fully discussed in a bulletin which is soon to be issued by the Department.

I want to call your attention to this difference in the varieties, because a great many growers, all the way from here to Kentucky, have sent in orders for one bushel, five bushels, 120 bushels, of "velvet beans," not specifying any variety. When they are planted they are sure to be disappointed. When the Yokohama and Georgia varieties are planted in south Florida they waste half a year. When you plant velvet beans, select the variety suited to your particular locality. The best variety for any locality is one which will continue growing without stopping to mature the seed until just before the vines are to be killed by frost. That day, of course, is a little uncertain, but it can be approximated for each locality.

The beans produce an immense yield. We have very little data giving specified yields of hay and beans, from the fact that the crop is very rarely cleaned from the fields. The vine is long and difficult to cut, and it is commonly utilized for grazing. The beans, when they are gathered, are gathered by the hundred pounds; and it is rare that they are gathered clean, because when 
left in the field they are good for feed; but an arerage yijelifif beans and vines would be from two to four tons per acre; if they are good and dry like hay that would be a good estimate. The yield of beans in the pods varies all the way from threequarters of a ton to something over two tons. In Mississippi I have known something over two tons of seed per acre to be grown.

The principal use of the velvet bean, in addition to this humus making, is for winter grazing. Most legumes, such as cow peas, soy beans, etc., the leaves break off very quickly, and after dropping they are decayed and the whole plant is worthless in a few days after the first touch of frost. The velvet bean is very tough, though; and the beans, leaves and vines resist decay for many weeks or even months. Neither do the beans decay when left on the ground during the winter. In fact, in central and southern Florida many varieties retain their vitality so completely that when a field has once been seeded volunteer crops will follow for many years, and even in southern Mississippi this sometimes occurs. The vines grow much larger and seed much more freely when they are supported from the ground by means of poles, and a grain of corn soon develops into an efficient and inexpensive pole. Not much corn may be secured from such a planting on new ground, but the presence of the stalks will add largely to the yield of both vines and beans. When planted on old fields they are usually planted with corn, nearly all of which can be gathered before the bean vines are large enough to cause serious inconvenience, and the few ears which will be missed will be found and eaten when the field is grazed.

They are far superior to any other legume which we could have for that purpose. The quality of the feed is excellent. I have seen steers sell in February ready for the butcher. They had no other feed except this from December until sent to the butcher in February. The most economical way to handle the crop is to give the cattle the first grazing; let them go over the fields and clean them, and after they have cleaned off the best of it the hogs can be turned in and they will get about as much as the cattle got. If the crop is reserved for hog pasture it will give more pork than we can get from most any other crop. I know where four to six hundred pounds of pork have been made per acre from this one crop. I have known of some instances where

Velvet Beans Best for Winter Use

May Be

Grown Simultancously With Corn 
Experiments Show Value of Velvet Beans for Soil Enrichment ine yield of pork per acre has been more than double that amount, but we have definite records of over six hundred pounds of pork per acre; and after the hogs are taken off the field there are the remains of the vines and the droppings of the hogs left on the ground to add to the fertility of the soil.

As a restorative crop for exhausted soils, velvet beans are even more valuable than cow peas, as they grow larger and so produce more humus and add more nitrogen to the soil. Professor Ross, of the Alabama Station, shows the fertilizing value of a crop of two tons of vines and beans to have a value of about $\$ 55.00$ per acre, the valuation being based on the present prices of commercial fertilizers; and this valuation was fully justified in the increase in yield of the crops which followed. Bulletin 120 , of the Alabama Station, says that following a crop of the beans on a sandy soil the yield! of cotton was increased 18 per cent, corn 32 per cent, fall-sown oats 334 per cent, and of wheat 280 per cent. This great increase was, doubtless, due partly to the fertilizing elements contained in the bean crop, and partly to the betterment of the condition of the soil by the addition of the humus. Station analyses show that an ordinary crop of the beans will add as much plant food to the soil as is contained in 1,400 pounds of cottonseed meal, and that, in addition to its humus-making and other beneficial effects. Every Experiment Station official with whom I have corresponded has been emphatic in stating that the fertilizing value alone was worth far more than the entire cost of growing the crop, thus leaving its pasture and seed value as clear profit.

This is the experience which has been given to me by many Station authorities with whom I have talked. Within the last twelve years, since the propaganda in favor of their cultivation has been going on, the increase in cultivation has been immense. The increase in Louisiana is very great; I don't know the exact acreage.

The plantings in Mississippi will be over a million acres this year.

The papers sometimes call me a velvet bean crank. Perhaps I am; but I hardly know the difference between a crank and a man who pushes a good thing when he sees it. I am pushing velvet beans. It is twenty years since I planted the first crop and $I$ have been for it ever since, and I believe it is the best crop 
we have for taming and fertilizing the soil, for furnishing winter grazing and for restoring the fertility to exhausted soil. It is undoubtedly the pioneer crop for our cut-over lands. (Applause.)

Mr. Thompson: What variety of bean would you advise for Texas?

Mr. Tracy: How many months have you without frost?

Mr. Thompson: We don't have frost before the latter part of November, until the last days in March.

Mr. Tracy: I would use the Chinese or the Osceola. The Osceola is a little later than the Chinese-a week or two.

\section{Need of Experiment Station Work on Cut-Over Lands By W. R. Dodson}

Dean of the State College, Director of the Experiment Stations of the State of Louisiana

I think the miscellaneous discussion indulged in after $\mathrm{Mr}$. Piper's address justifies me in the assertion that we have entirely inadequate information as to what can be done on these lands in a definite, specific way to tell the average inquirer what he might expect us to know. I don't know but one way to get that information, and that is to get the experiment staiions to do these things over a series of years to get the average conditions and make the average deduction from it.

I was just thinking, when we were talking about this question, suppose they had been in the very definite form of questions, and we had said to some of these gentlemen: How many tons of velvet beans can you expect to gain, as an average, on the long leaf yellow pine cut-over lands? How much cow pea hay can you expect? How many tons of beef can you make on an acre of land an average year, and how much will it cost you?

Exact Knowledge What Is Lacking How many pounds of pork can you make on an average acre of land on an average season in the general type of long leaf and short leaf yellow pine region? And I don't believe you could answer those questions, because you don't know. The only way I

Best Beans for Use in Texas 
Federal and State Co-operation Best know of to get that information is to try it and see; and the people that are best equipped to get reliable information of this kind are people that have no land to sell, that have no personal interest in the results that are to come from those experiments, so that they can be uninfluenced as to whether the results are favorable or unfavorable; and there will be no temptation to look to the good results with a magnifying eye, and the bad results in a diminished estimate, so that the whole truth, by an unprejudiced, disinterested party, can go into things of this kind; and that means somebody maintained either by the Federal or state funds, or by funds that may be subscribed to by interested people; but the best way, I think, is the basis on which we have worked it out for other experiments, by Federal and state support-so that these men will not be under obligations to anybody. They should not be censored as to what they shall say or can keep from saying about their results.

I believe there is a great future for these lands. This is the first effort I know of where we have had represented in conference so much talent, men that are deeply interested in the outcome; where the Government representatives of the Department of Agriculture, the Colleges of Agriculture, the State Departments of Agriculture, the land owners and the railroads and the bankers, all of these people who would be materially affected, both in a material way and in the advancement of the public welfare, have tried to put their heads together.

Now, let us not be deceived by trying to take short-cut methods. Let us be candid with one another, and with the prospective farm owners, and let them see that we are going to solve these questions. Enough has been tried to make the outlook very encouraging. Enough information has been brought out to show that there is a lot more to do; that this is not plain sailing; and that if everything was known that the men want to know you would not be here today. The fact that some of your lands have been offered and have not been taken is an indication that you are not able to tell the prospective purchasers what they want to know. They are not going to listen to you very well until you are able to tell them, and then be able to stand by your statements. Until we have the information that will enable us to look a man square in the eye and tell hin with a clear conscience that he can do this, and he can expect so and so, and here are the difficulties 
to be overcome, and give him a frank statement of what he might expect, you will not get very much development or utilization of these lands; but when you are able to do that, and you can tell by experience and facts that the land might do this or that, you will do well in selling lands.

In formulating your plans I hope you will lay a broad foundation; work out a plan by which the men that are permanently in this kind of work may correlate their efforts with the Federal authorities and state authorities and the people who have their money in the land, so they can work together on a permanent basis. Until we make such arrangements we will work with a dissipation of our energies and loss of money and time; and so, in formulating your plans I hope you will make ample provision for experimental data to be obtained by impartial men, to extend over a sufficient period to eliminate great variations in seasons, so that due attention will be given to selecting original areas that will be as typical of large areas as possible; that that information shall be given without restriction and without limitations to those that will be interested in it; that it will be financed on a basis that will not make anybody feel under obligations to keep something back. I believe when we do that we will work out a plan by which these lands will offer very attractive propositions for a great many people.

I only want to give you one illustration of what I mean. We have been talking today about rich lands and poor lands. Rich land and poor land are simply relative terms. We say poor land when we are thinking about the production of cotton, and it means one thing; and we say poor land when we think of the production of sweet potatoes, and it means another thing. If I were to go to Alexandria, for instance, which is on the border line of the long leaf pine country and I wanted to grow corn on the north and the alluvial land on the south, and I would say, "Which is the best land, over there on the hills or over here in the bottoms" and everybody would say, "Over here in the bottoms ; you can't grow any corn on hilly land." But suppose I wanted to raise sweet potatoes, and I ask, "Where can I raise the best sweet potatoes-over here in the sandy loams or over there in the Red River bottom land," and the man would say, "You can raise much better potatoes on the hill land than you can on the stiff soils," and therefore that pine land is richer for you than the Red River bottom. That is simply an illustration of the

Much Prelininary Work Necessary

Where

"Poor" Lands Are "Rich" Lands 
indefinite meaning of the terms in which we speak. I hope you will go ahead and keep this work up until this problem of gaining adequate information regarding the cut-over pine lands is solved.

\section{Mississippi's Part in Cut-Over Land Development $B y$ Dr. E. R. Lloyd} Director of Experiment Stations of the State of Mississippi

I have been somewhat amused at the apparent incompatibility between Dr. Piper's ideas of the cut-over land and the ideas of the other gentlemen. It seems to me that Dr. Piper was talking about one type of cut-over land and the other gentlemen were talking about another type, and both correct from their different points of view.

We have a vast deal of cut-over land in Mississippi which is really splendid agricultural land. We also have a great deal of cut-over land in Mississippi which is hardly worth while as agricultural land, and Dr. Piper was entirely correct when he said that on this poorer type of soil we cannot grow very much of a crop and to make a good pasture will be both difficult and expensive. While on the better type, which has a good red-clay subsoil, we can grcw many profitable field crops besides lespedeza and Bermuda for pasture.

In developing this cut-over territory it seems to me, Mr. Chairman, that the first thing to be done, so far as Mississippi is concerned, is to repeal some legislation we already have. These lands will never be developed through individual effort; they will be

Vicious Legislation Retards Development developed by corporations with money; but so long as we have such laws on our statute books as we have today, these cut-over lands are not going to be developed very rapidly. And it seems to me with an organization made up of some of the best business men of the country something might be done if the proper effort was made to repeal the vicious laws which now retard progress in the state's development. We desire to see these lands developed on a per- 
manent rather than on a speculative basis. One of the serious troubles with Southern agriculture today is its unstable character. If some practical plan could be worked out by which agriculture in all its phases could be stabilized and conducted on a safe and sane basis, it would be the most profitable business for the greatest number of our people to engage in.

When the cut-over lands are developed it will necessarily be on rather a large scale, and live stock offers perhaps the safest returns, since with live stock we can handle the maximum amount of land with the minimum amount of labor, while with crops the conditions are reversed.

We are working in a small way through our Extension Department of the Agricultural College of Mississippi and our Branch Experiment Station at McNeill in Pearl River County with the small farmers in the cut-over territory. Our purpose is to help them develop their small farms on a permanent basis by combining live stock with crops.

The plan we suggest is for each small farmer to have five dairy cows, two brood sows, twenty-five sheep, twenty-five head of poultry, and then plan his crops so that feed enough to carry all live stock will be produced, with a small surplus for sale. The bankers and businesș organizations in many counties have agreed to finance these small farmers, and our demonstration agents will help plan his crop rotations and teach him the best methods of handling his live stock as well as assist him in marketing his surplus products.

We do not expect very large areas of this cut-over land to be converted into small farms immediately, but we think this a beginning in the right direction.

In the past the absence of cheap money and long-time loans prevented many from going on the farm. but since the passage of the Federal Farm Loan Act we find the interest in farming increasing. While I consider the passage of the Federal Farm Loan Act one of the most constructive pieces of legislation passed in recent years, I also think that cheap money is a menace to the masses. Cheap money on long-time payments is very alluring, and I fear too many will avail themselves of the opportunity to borrow money without having first carefully worked out plans for its safe investment. I think every man who borrows money should be required to submit in writing a carefully thought out plan for spending the money and have this plan approved by a competent committee.

Financing the Small Farmer

The Good and Evil in Cheap Money 


\section{What Georgia Is Doing to Encourage the Utilizing of Cut-Over Lands}

\section{By John R. Fain}

Agronomist of the College of Agriculture of the State of Georgia

Gentlemen, I am with you today because President Soule, of our institution, was detained at home on account of a campaign we are carrying on in Georgia at this time. He asked me to express to you his regret at not being able to be present.

I would like to say to you that our institution is represented because we thought this was one of the big constructive pieces of work being undertaken in the Southern states. I will try to present to you as briefly as I can some of the things that the College of Agriculture is trying to help in development.

We fancy that the College of Agriculture should be something of a clearing house for information for the people of the state, and that we should get together that information for them and be able to present it to them, and we bring it to your attention as some of the work we are trying to do. Therefore, I am going to use a few charts I have here for this purpose.

These figures were compiled from census reports and from estimates by President Soule. I am not going to take your time up to any great extent. We have a considerable number of live

Better Grades of Cattle Needed in South stock in the South; but the principal trouble is its quality and low value; and I might use these figures from the State of Georgia. I will say that in the fifteen Southern states, in the six years from 1910 to 1916 , the beef cattle decreased something like three-quarters of a million. It struck me, in listening to the discussion yesterday, that a great many of those cattle could have been maintained on some of the seventy-odd million acres of land in this country.

Now, outside of the quality there is another factor, and that is loss from disease and exposure in these Southern states. Take the state of Georgia. We believe in presenting to the peo- 
ple the actual conditions. IVe think that because we sometimes have a mild climate that the loss doesn't amount to anything. Run down that column: Loss from disease, cattle, 25 per thousand; from exposure, 25 per thousand; sheep, from disease, 31 per thousand; from exposure, 31 per thousand; swine, from disease, 71 per thousand. These are the figures from the North Atlantic states, much lower than from Georgia. If we are going to do anything with the live stock business, we must reduce that rate of loss.

This is the status of the live stock industry in Georgia, showing there has been a decided increase in number in our state. The large increase there is from hogs. The increase from the other animals does not amount to very much.

Now, as to the replacement, taking the state of Georgia: The average of horses and mules compares very favorably with the average in the country as a whole, but, unfortunately, those are the things we buy. We buy most of our horses and mules; we do not raise them. The average value of our cattle is $\$ 16.20$ as against $\$ 35.88$ in the rest of the country; sheep, our value is $\$ 2.80$ as against $\$ 7.14$; swine, $\$ 9.00$ as against $\$ 11.73$.

Another line of work we are trying to carry on is something of the food problem. Here we havel three foodstuffs: Silage and cottonseed meal give the greatest production of butter. This year we are trying out cottonseed meal, peanut meal and velvet bean for dairy cattle, to be presented to the people another year.

This chart indicates something of the relative number of the blooded cows and the good cows that will be required to make the same profit. We have good dairy cows that make as much profit as 41 of our average dairy cows in the state. Another condition we are up against is the relative food value of different crops that we can grow.

Now, as to the question of what we can do with live stock. This is in the Coastal Plain region. This is a statement of the value of live stock at the Agricultural College. They started in September, 1907 , with $\$ 1,917$ worth of live stock. They have spent from that time up to June 1,1916 , over $\$ 9,000$. The value of live stock in June, 1916 , was $\$ 17,000$. Here is an item I call your attention to: For the purchase of live stock we spent over a thousand dollars a year, with sales of live stock to June, 1916, amounting to $\$ 14,000$. The average increase in the inventory

One Good Cow Worth 41 Poor Ones
Losses from Disease and Exposure 
Best Silage

Foods for

Coastal Plain

States

Experiments With Grasses

has amounted to about $\$ 1,700$. So far it has been a pretty good financial proposition.

Now, as to the work of the College in taking it to the people: This is a summary of the work by the county agents. Our county agents have inoculated hogs and cattle for cholera to the number of about 65,000 . The pure bred animals purchased through the county agents and the specialists of the Department of Agriculture, who are co-operating with these men, has amounted in the past year to over 7,000 head brought into the state; and that is where we are trying to correct the low valuation in live stock.

Now, in regard to the food proposition: We have been advocating the building of silos over the state of Georgia, and we are advocating, as a crop for the Coastal Plain, a mixture of kaffir corn and sorghum. We have suggested the red head sorghum and the black kaffir corn.

The silage and velvet bean, we believe, solves the problem of carrying the animal in the Coastal Plain region at least through the winter months. The problem, as we see it, is that it is a limiting factor in cattle production in the Coastal Plain region, and it is a limiting factor especially in the months of July, August and September. Now, if we can solve that problem I believe we can help establish on a permanent basis the cattle business of the South.

We started out to make an inventory of what we had and what could be utilized, and we have a young man who is spending part of his time studying the growth of the Coastal Plain section; and, incidentally, there we found one man who had been for the past fifteen years utilizing a pasture of grass and lespedeza with apparently pretty good success. That probably will not be adopted except in a limited area, but in that area it might be a solution of the problem. At the present time we are recommending the carpet grass, as Dr. Piper suggested. The only two grasses we have found, of the ordinary tame grasses, that justify continuous work with them is the red top and meadow grass. In one case we have gotten good results from work of that kind.

We have two areas in the Coastal Plain in which we are trying to study in a similar way the forage crop situation for that section of the state, and we hope before a great while to be able to increase this and to do more work. 
Now, just a word on a proposition that was brought up here yesterday, and that was the size of farm that is going to be profitable on these cut-over lands. We had submitted to us not a great while ago a plan to buy some of this cut-over land, fence it off in forty-acre tracts, build a barn and house, and sell it to prospective settlers, and they asked our opinion on it. That letter was referred to me to answer, and I answered it in this way: "We have made a survey in the southern part of the state which showed that the men who were cultivating fifty acres or less had a labor income of about $\$ 200$. The men cultivating 200 acres had an income of between $\$ 600$ and $\$ 700$. Would you rather take a chance of getting your money back from the man who made $\$ 200$ or the man who got $\$ 600$ or $\$ 700$ ?"

We are also co-operating with the railroads in developing a few farms along their line of route where their scheme is this: The railroads go to this man and say, if you will follow our instructions we will guarantee you against loss up to $\$ 200$. They come to the College and ask us to outline the work, and that is being carried on under the supervision of one of the graduates of the College and is paid for by the railroads. This work has just begun, and we hope in a year or so to have several more of these farms.

It might be of some interest to you to know what some of the men grazing this cut-over land are making. We have a record of one man who is cultivating 750 acres. He is renting, in addition, 1,000 acres of cut-over land for pasture. His record showed a labor income of $\$ 6,000,36$ per cent of that coming from his live stock. By gathering information of that kind the College hopes to be, in a way, of some help in this development. (Applause.)

Co-sperating

With the

Railroads 


\section{Beef Cattle and Hogs By George M. Rommel} Chief, Animal Husbandry Division, United States Department of Agriculture

Nation Demands More Meat Production
It seems to me that the question of meat production in the South is one of the most important questions which the nation has before it today. I will not burden you with a great many tiresome statistics, but I want to point out a few of the high lights of our meat trade at the present time. In the fiscal year ending June 30,1914, we exported less than seven million pounds of fresh beef. In the next fiscal year we exported over 170 million pounds of fresh beef; and in the last fiscal year over 231 million pounds; the value of our meat exports in these years grew from 143 million dollars in 1914 to 266 million dollars in 1916. In the fiscal year 1914 we imported a normal amount of wool-245 million pounds. In the fiscal year 1916 we imported 525 million pounds. Furthermore, I am told, not officially, that the meat ration of a soldier in the trenches in Europe is ten ounces per day. There are something in the neighborhood of 25 million soldiers in that section being fed better than they were ever fed before in their lives. The United States is already planning to put an army of two million men in the field, all of whom will be fed as well, if not better, than the armies of the nations of Europe. This enormous increase in our meat exports and in our wool imports has largely been brought about by the demands of warfare, and I candidly say to you, is there any problem which could more earnestly engage our attention than the question of how to meet this demand without starving the civilian population and allowing them to go without proper food and clothing?

Now, gentlemen, I come to the question of beef production, and in approaching this question I wish to make my position exactly clear so that what I will have to say will not be misunderstood.

It seems to me that a great many of the speakers who have been discussing the question of the utilization of these cut-over lands have been thinking on too small a scale. I make that statement in no spirit of criticism, but as a statement of fact. If there is one thing, Mr. Chairman, for which this convention has 
been remarkable, it is the seriousness, the earnestness of discussion and the directness with which the speakers have approached the point. We have had an unusual absence of what we are pleased to call "hot air." Now, at the risk of offending in this very respect, I wish to indulge in a few figures. The acreage, as generally agreed upon, is 76 million acres of cut-over timber lands on the Coastal Plain and contiguous territories. That doesn't mean much to me, because I can't think in millions; some men can, but I can't. But when I ran through a table showing the acreage of the states in the South I was staggered. Do you realize that that acreage is half the acreage of the entire state of Texas? Do you realize you can take the entire state of Florida, add the state of Georgia and take a chunk out of South Carolina, and you would have an acreage representing the acreage of these cut-over lands? Furthermore, your secretary told me at lunch today that that acreage is being added to at the rate of 10 million acres a year, and that ultimately we will have added to the 76 million acres which we now have an acreage of 250 million acres, a total that is larger, gentlemen, than the present unallotted, unused, unassigned, undeveloped acreage of the public range in the IVest; an empire, if you please, in extent; in area equal to almost any ten of your Southern states; and nothing is being done with it. Now, this Conference, as I understand it, has been called to consider a constructive plan of development. I cannot tell you how much I appreciate what Dean Dodson said on this subject-when a man who stands as he does in the state and nation stands before you and tells you what he told you, then any damn Yankee that comes down from the North can feel pretty safe in taking such a position. (Applause.)

I grant you, gentlemen, the correctness of the position set forth in that splendid paper written by Mr. Graves, the Chief Forester of the United States. This problem has three phasesreforestation, grazing and agriculture. What is being done now in reforestation? You know better than I do. What can be done in agriculture? The statement has been made here, uncontradicted, that only 15 million acres-only one-fifth of the present

What Shall We Do With It?

\section{Cut-Over \\ Lands Cover an Empire}

Cut-Over Area

Increasing

Ten Million Acres a Year available area-are suitable for agricultural development at the present time. What are you going to do with the other fourfifths? You are not reforesting it. It seems to me that leaves it open to either one of the three possibilities, straight farming, cattle raising or sheep raising. 
Where Agriculture is Impracticable

\section{Live Stock} Raising Will Solve Problem
Now furthermore, just for the sake of illustration, suppose that the entire 76 million acres were available for agriculture, and suppose that we tried to get into effect that splendid ideal of the government's public land policy-a family on each forty acres and each family supporting itself-suppose you could realize that ideal. Dividing the 76 million by 40 acres leaves you $1,875,000$ tracts, and will anyone tell you where we will get 1 ,875,000 families to settle this land on a forty acre basis? It would be impossible. This problem is now. We can't look 25 or 50 years hence when we may have a surplus of farmers. Furthermore, we can't go to the cities and bring men from the cities to settle on these lands.

That brings me to another point: If there is one thing that the United States is going to learn from its entrance into the war it is that we are no longer provincial; we are coming to learn that we have an obligation owing not only to our neighbors in our country, but that we owe an obligation to the world itself. We are coming to learn that we cannot take from another without giving something in return. We are not getting any more immigration; it stopped at the beginning of the war. About a month before I left Washington the statement was published by the Bureau of Immigration that a large emigration from the United States was expected when the war closed; that the steamship agencies already are swamped with bookings for people to go back to their countries and carry the atmosphere of freedom back to the lands where they were born. We cannot confidently look to immigration as a source of settlers for cut-over lands. That compels a line of development closely related to present available labor supplies. It seems, therefore, that the development of these lands on a strictly farming basis is a matter of the somewhat cistant future. The most promising immediate development is along live stock lines, particularly with beef cattle and sheep.

Now then, understand that when I make this statement I am making it as an animal expert, but I have tried, as well as any specialist can, to see this matter in a broad, comprehensive light; but I cannot get away from the idea that the one plan for development at this time, on these cut-over timber lands, is to develop live stock raising on a comprehensive and broad-minded scale. This territory is what you might call a virgin territory. It is closely analogous to the great plains of the West fifty years ago. 'The 
land is there, and the first thing to do in this development is to follow the most promising line that offers.

There has been only one speaker at this Conference-and I make this statement without any spirit of criticism-there has been only one speaker who has even hinted that the question of labor is going to cut any figure here. We know what we can do in the way of raising crops for hogs. There is a lot of information on the success of live stock farming under intensified conditions, such as Mr. Enochs described; but, gentlemen, you are talking in terms of 76 million acres, not in terms of 160 or 320 or 640 acres. You are dealing in big things. It is a tremendous proposition. This is no child's play; it is a man's game; and it is a game that will call for all the brains and intelligence that can be brought in to it.

Meat production in the United States has not been keeping pace with the increase in population. Without burdening you with a large array of statistical information, I will simply call your attention to the number of meat animals in the country in Nation's Scarcity of Beef 1900, 1910 and 1917.

In round numbers there were reported in the 1900 census seventeen million dairy cows and fifty million "other" cattle, the latter being principally beef cattle. In 1910 there were twenty million dairy cows and forty-one million other cattle. In 1917 there were twenty-two million milch cows and forty million other cattle.

We observe that there has been a considerable increase in the number of milch cows, from seventeen million to twenty-two million in seventeen years, an increase of almost thirty per cent. On the other hand, in the case of beef cattle there has been a decrease of over nine million head, or eighteen per cent.

Of sheep, the country possessed in 1900 sixty-one million head; in 1910 fifty-two million head, and in 1917 forty-eight million head, a decrease of thirteen million head. In the case of swine, on the other hand, we see an increase. In 1900 there were sixty-two million head; in 1910 fifty-eight million head; in 1917 sixty-seven million head, a net increase of five million head: These figures are taken from the census figures, and from the estimates of the Department of Agriculture. An accurate statistical comparability is impossible, on account of the different conditions under which the two censuses were compiled, the dates at

Sheep

Decreasing;

Swine

Increasing 
which the figures were gathered, and the different systems used in obtaining the figures. However, light is obtained on the same subject from the reports of meat animals slaughtered under federal inspection at packing plants throughout the country. The following table shows the number of establishments and the total number of animals inspected at slaughter under federal inspection annually from the beginning of inspection in the fiscal year 1907, up to and including the fiscal year ended June 30, 1916:

\section{NUMBER OF ESTABLISHMENTS AND TOTAL NUMBER OF ANIMALS INSPECTED AT SLAUGHTER UNDER FEDERAL INSPECTION ANNUALLY, 1907-1916.}

Fiscal Year
1907
1908
1909
1910
1911
1912
1913
1914
1915
1916

Swine
$31,815,900$
$35,113,077$
$35,427,931$
$27,656,021$
$29,916,363$
$34,966,378$
$32,287,538$
$33,289,705$
$36,247,958$
$40,482,799$

Establishments
708
787
876
919
936
940
910
893
896
875

Sheep
$9,681,876$
$9,702,545$
$10,802,903$
$11,149,937$
$13,005,502$
$14,208,724$
$14,724,465$
$14,958,834$
$12,909,089$
$11,985,926$

Cattle
$7,621,717$
$7,116,275$
$7,325,337$
$7,962,189$
$7,781,030$
$7,532,005$
$7,155,816$
$6,724,117$
$6,964,402$
$7,404,288$

Goats

52,149

45,953

69,193

115,811

54,145

63,983

56,556

121,827

165,533

180,355
Calves

$1,763,574$

$1,995,487$

2,046,711

$2,295,099$

$2,219,908$

$2,242,929$

$2,098,484$

$1,814,904$

$1,735,902$

$2,048,022$

All Animals

$50,935,216$

$53,973,337$

$55,672,075$

$49,179,057$

$52,976,948$

$59,014,019$

$56,322,859$

$56,909.387$

$58,022,884$

$62,101,391$

There were $7,621,717$ cattle slaughtered for inspection in the year 1907 ; in the year 1910 this number had increased to $7,962,189$, from which point there has been a tendency to decrease, until the year 1915. The number slaughtered in the year 1916 was $7,404,288$, which is 200,000 less than in the year 1907. The slaughter of calves is not significant. The slaughter of swine, 
on the other hand is profoundly significant, a general tendency to increase being noticed from the year 1907, when $31,815,900$ head of swine were inspected, to the year 1916, when $40,482,799$ were inspected, an increase of almost nine million head. Sheep, on the other hand, show an increase to the year 1914, when 14,958,834 were inspected, from which time the decrease has been pronounced, a total of $11,985,926$ being reported for the last fiscal year, as against 9,681,876 in 1907. The total number of animals inspected at slaughter has increased from 50,935,216 in 1907 to $62,101,391$ in 1916, 77.62 per cent of this being due to the increase in swine slaughterings.

Up to the outbreak of the great war, our population was increasing at the rate of twenty-five per cent per decade. The significance of these figures is therefore apparent. There is no doubt that our producers of beef cattle are doing everything which is economically possible at the present time to increase the output, but they have not yet overcome the effects of the depression of ten years ago. The increase in pork production, which has been rapid during the last ten years, is all that has saved the country from a most serious meat shortage. The per capita consumption of meat in the United States has actually decreased during this time. Any head of a family on a moderate income can bear witness to this fact.

The entire problem is an economic one. Confining our attention solely to beef and pork production, we may observe that hogs are much more economical animals to produce on the farm than beef cattle. The classic investigations of Lawes and Gilbert showed that a steer required 777 pounds of digestible organic matter to make 100 pounds of increase in live weight, whereas a pig required only 353 pounds of digestible matter to make a similar gain. Expressed in another way, Jordan has shown that the pig returns 25 pounds of marketable product for each one hunEconomy in Pig Raising dred pounds of digestible matter consumed, of which 15.6 pounds are edible solids, whereas a steer returns only 8.3 pounds of marketable product, of which only 2.8 pounds are digestible solids. This greater economy of production for feed consumed accounts for the large increase in pork production on the high-priced lands of the corn belt, while beef production there has been almost at a standstill.

Cattle, however, are a necessity in economical farm management, when large quantities of unmarketable roughage are pro- 
Hog Production in South Increasing

duced. The high-priced corn belt farms produce tremendous quantities of corn stover and large amounts of straw. Formerly these products were largely wasted, but the necessity to get returns on the heavy investment now requires their conservation. The silo, the stover shredder, rations in which straw forms an important part, and other methods of conservation have become necessary. Nothing takes the place of cattle in so utilizing coarse, unmarketable forage. Whether the cattle will be used for beef production or dairy production depends entirely upon labor, marketing and transportation conditions.

The problem of the economy of pork production in the South is solved to a large extent. The increase in the number of hogs in Southern territory has been a striking feature of the agriculture of that section during recent years. One of the most interesting reports of this character is found in the percentage of hogs in the country on January 1, 1916, as compared with January 1,1915 . At that time there were fourteen states which reported an increase of ten per cent. or more in the number of hogs on January 1, 1916. Of these fourteen states, only two were strictly corn belt states, and of the remaining twelve, five were Southern states, namely, South Carolina, Georgia, Alabama, Louisiana and Texas. The increase during the last calendar year was not so pronounced, largely on account of the high prices for hogs prevailing during the year 1916, but there is no reason to believe that the tendency in Southern states to increase the number of hogs has yet reached its maximum.

For convenient reference $\mathrm{I}$ am including here a table of figures from the Department of Agriculture, showing the increase in the number of hogs in Southern states from 1914 to 1917.

\section{NUMBER OF HOGS JANUARY 1.}

$\begin{array}{lrrrrr} & 1914 & 1915 & 1916 & 1917 & \text { Increase } \\ \text { Maryland . . } & 332,000 & 349,000 & 359,000 & 359,000 & 27,000 \\ \text { Virginia. . . } & 869,000 & 956,000 & 1,023,000 & 1,023,000 & 154,000 \\ \text { W. Virginia . } & 367,000 & 374,000 & 378,000 & 380,000 & 13,000 \\ \text { N. Carolina. } & 1,362,000 & 1,525,000 & 1,550,000 & 1,550,000 & 188,000 \\ \text { S. Carolina . } & 780,000 & 819,000 & 870,000 & 920,000 & 140,000 \\ \text { Georgia. . . . } & 1,945,000 & 2,042,000 & 2,348,000 & 2,585,000 & 640,000 \\ \text { Florida. . . . } & 904,000 & 949,000 & 996,000 & 1,100,000 & 196,000 \\ \text { Tennessee. . } & 1,320,000 & 1,501,000 & 1,531,000 & 1,485,000 & 165,000\end{array}$


$\begin{array}{lllll}1914 & 1915 & 1916 & 1917 & \text { Increase }\end{array}$

$\begin{array}{lrrrrr}\text { Alabama. . . } & 1,485,000 & 1,559,000 & 1,715,000 & 1,850,000 & 365,000 \\ \text { Mississippi. . } & 1,467,000 & 1,540,000 & 1,617,000 & 1,698,000 & 231,000 \\ \text { Louisiana. . . } & 1,398,000 & 1,412,000 & 1,553,000 & 1,584,000 & 186,000 \\ \text { Texas. . . . . } & 2,618,000 & 2,880,000 & 3,197,000 & 3,229,000 & 611,000 \\ \text { Cklahoma. . } & 1,352,000 & 1,420,000 & 1,491,000 & 3,372,000 & 20,000 \\ \text { Arkansas. . . } & 1,498,000 & 1,573,000 & 1,589,000 & 1,575,000 & 77,000\end{array}$

Total. . . . $\overline{17,697,000} \overline{18,890,000} \overline{20,217,000} \overline{20,710,000} \overline{3,013,000}$

The control of hog cholera is no more difficult in the South than in the corn belt, but the control of parasitic pests, both internal and external, requires more careful attention than in the North. Economical pork production in the South is based on the use of forage crops and the proper use of these crops in rotation helps materially in handling the problem of internal parasites.

In many sections peanuts are largely used for grazing hogs, resulting in the production of an oily pork. Mast-fed hogs have long been subject to "dockage" on sale. Now the peanut hog has joined this tabooed company and all Southern hogs reach Northern markets under suspicion. So long as the fresh pork market is as strong as it is at the present time, this condition does not preclude profitable hog production. Sooner or later, however, the problem must be solved, and methods of finishing devised which will harden the meat of hogs raised on forage crops which produce fats with low melting points. This is undoubtedly the most serious problem in Southern pork production. A similar probiem was satisfactorily solved by Danish and Canadian scientists, and a number of investigators in the Southern field, notably Gray, of North Carolina, are now engaged upon it. There is no reason to believe that it will not be solved in due time.

The first great problem in Southern beef production is tick eradication. This problem is now fairly on its way to the halfmile post. Needless to say, the second half will be made in much better time than the first. It must be admitted, however, that the first territory to be cleared of tick infestation was the territory which was most promising for cattle production, or in which a certain amount of cattle production has been in progress for a considerable time. From one standpoint, the easy work has been done, and the territory still under quarantine includes some sections in which tick eradication work will be extremely difficult.

Problem of Finishing Being Solved 
To offset this difficulty we may observe that full ten years have been taken to accomplish what has already been done. A large amount of this time has been consumed in educational propaganda. The education which the country has received as to the value of tick eradication will undoubtedly go a long way toward overcoming the natural obstacles which confront the eradicators in the territory still under quarantine. The wisdom of the policy

Tick Being Eliminated as a Factor of the past shows clearly, and the merit of the movement is now generally recognized. With the majority of men, women and children in the South now recognizing the importance of getting rid of the cattle tick, a much larger amount of the effort of the next ten years can be spent in active tick eradication work. The tick-free area has now reached the sea coast and by the end of the present calendar year we may expect to see released from quarantine at least one state which was in 1906 entirely tickinfested. This event will add to the impetus of the movement in other states and state-wide tick-eradication laws will not only appear on the statute books of all states where tick quarantine exists, but they will be sincerely and energetically administered.

We are thus rapidly adding to the country's tick-free territory. However, the common assumption that the eradication of Tick Eradica- the cattle tick automatically adds just so much area to the cattletion and the producing territory, is not exactly true. A large portion of the Cattle Producing Territory territory which has been released from quarantine during the last ten years has always produced cattle of sorts, but in much of the territory from which the tick is still to be driven out, the profitable production of beef cattle has been practically unknown.

Let me make myself exactly clear on this point. I admit the fact that in some sections which are primarily pasture sections, beef cattle have been profitably produced where ticks have been present and the infestation light, and considerable progress has been made in breeding up native stock by the use of purebred bulls. It is also a fact that in some sections where the "pineywoods" cattle are common, the owners have made a profit. It is still possible, no doubt, for a few individuals to make a living from cattle of this type, but such a business, regarded in the broad light of economics, cannot be said to be profitable as an industry. If the proper charge had been made for the use of the land over which these cattle grazed, the profit in their production would probably be reduced to zero. 
Methods of finishing cattle for market have been well worked out in certain sections of the South, and the possible profit by some of these methods was definitely shown, while the land on which the work was done was still under quarantine. We must admit, however, that a large portion of the area below the original quarantine line is not yet ready for the fattening of cattle. Until corn is produced in quantity and cheaply, or until other finishing feeds equally cheap and equally efficient, are produced, the raising of beef cattle for finishing elsewhere must be the chief feature of the beef business of the South. This is particularly true of the cut-over timber lands, and it is this territory which $I$ have in mind in making the foregoing remarks concerning the economical production of beef cattle in quarantined territory.

What do we really know about the cattle raising possibilities of these cut-over timber lands? The fact that piney-woods cattle range over them with little or no charge for the range, proves nothing from a business standpoint, except that the climatic conditions do not inhibit the growth of cattle. I might also say that the fact that men have reached a considerable degree of success in the production of pure-bred cattle in the South on cut-over timber lands proves only one thing, and that is that the South can produce just as good pure-bred beef cattle as any other section of the country, but it sheds very little light on the question of the utilization of 76 million acres of these lands. This is a ranching problem, a grazing problem.

If I may digress a moment, I venture the opinion that the presence of these native cattle in considerable numbers will be found to be an advantage when conditions are ready for the systematic development of an economic cattle raising industry. These native cows are hardy, acclimated, and will become a splendid foundation on which to build the cattle industry of the future. This native blood responds quickly to crossing with wellbred bulls, and in the course of a few systematic crosses, high grades will result which will be quite valuable as feeders.

This much we know, but before we can advise capital to invest extensively in the cattle business on cut-over timber lands, we must be sure that the cost of making these lands suitable for cattle production will not be so great as to prevent the enterprise from being profitable under proper management. I understand that the cost of ridding the land of stumps has been pretty well

Native Cattle an Asset

South Can Produce First-Grade Cattle 
worked out. The cost of fencing can very readily be ascertained. These and similar points being determined, we are at once face to face with the question of the productive value which these lands may then have for cattle grazing. By this time you are probably of the opinion that I am a doleful prophet, and that I am

Sees South as Nation's New Cattle Country

More and Better Pasturage Essential throwing cold water on the idea of developing these lands for cattle production. Far from it. I have for more than ten years maintained that our most promising future source of considerable increase in beef cattle production in this country is in the Southern territory south of the Ohio and east of the Mississippi rivers. The Western range has reached its capacity. The increase in production in the corn belt has not kept pace with the increase in population, and in order to supply the corn-producing sections with feeders at reasonable prices we must look to development in the South.

Regarding the territory as a whole, the cut-over timber lands are by nature promising for cattle producing purposes. But these cut-over timber lands at present do not produce cattle economically, and they will not produce cattle economically until the grass-producing possibilities of these lands are thoroughly demonstrated.

Granted, then, that for a somewhat long time to come, cattle raising rather than cattle fattening will prevail in the South as a whole, it is apparent that after tick eradication, the problem of most pressing importance, particularly in the cut-over timber country, will be the maintenace of the herds which will be established on the tick-freed areas. This maintenance problem has two phases - the pasture period and the wintering period. The pasture problem must be solved before the promised development of the Southern cattle industry becomes an accomplished fact. Not only in the cut-over timber lands, but elsewhere throughout the South, the pasture problem presents itself as the most important feature after the tick eradication problem is solved.

The botanical features of native Southern forage plants are, of course, well known. The adaptability of certain imported ones is also fairly well understood, but there is a very great deal to learn of the relative merits of different plants, their behavior when pastured, their proper management under pasture, and their productive value as pasture plants.

Just one question is a fair example of the importance of these problems, and this one question crystallizes everything 
which I have said on this subject. How many acres of cut-over timber land are necessary to carry a cow through the season? Do you know? I do not, and I have never met a man who does.

By way of explanation, let me say that this was written before I had the pleasure of meeting our good friend, Mr. Thompson, of Texas. Mr. Thompson was the first man able to give me an intelligent answer to that question. He said yesterday that when they started on that 60,000 -acre tract in Trinity and Polk Counties, in Texas, they estimated they would carry one cow on every fifteen acres; but he says that he has found they can almost cut it in two, and now they estimate that around seven to ten acres will be required to keep a cow for the season.

The first thought which an investor should consider before going into cattle raising in these sections, is this very question. It therefore seems incumbent on all of us who are interested in this problem to bend every effort to bring about a speedy accumulation of accurate information on the pasture question, and the problem should be studied under different types of conditions, each type related to the whole, so that when we have accumulated data, it will not be fragmentary, but each part will fill a niche in the construction of the entire structure.

The wintering problem does not give one nearly so much concern as does the problem of pasturing through the growing season. The wintering problem can be solved by foresight. We are apt to overlook the fact that during the short winter in the South, losses among cattle may be quite as serious as on the ranges of the West, unless owners have fortified themselves with a sufficient supply of feed to carry the animals through. Under the best climatic conditions, cattle of the age of yearlings up, will lose from fifty to one hundred pounds during the winter when forced to subsist on cotton-stalk fields and cane brakes. When winter conditions such as occurred during the winter of 1916-17 prevail, heavy losses result. Thousands of cows died in Plenty of Feed in Winter Essential the South during the past winter. The weather had something to do with these deaths, but shortage of feed was the principal cause. All this loss might have been prevented if one of two things had been done: .First, if the owner had not stocked up with more cattle than he had feed for; second, if he had taken precaution to provide sufficient feed in advance to carry the cows through the winter. In any cattle enterprise on cut-over lands,

Seven to Ten Acres to a Coiv

$$
\text { ( }
$$


Systematic

Study of Pasturage Prob. lem Urged

How Prompt Results May Be Obtained selected areas can doubtless be found on which feed production can be economically carried on to produce a sufficient quantity of hay and silage to carry the cows through the winter. Where an owner is caught with more cattle than he has feed for, he is in a serious predicament. A sufficient supply of silage and hay, silage and cottonseed meal, or even of hay alone, would have been cheap insurance against the losses of last winter.

As a constructive suggestion, it is advised that the pasture problem be attacked without delay in a systematic, thorough and practical manner, co-operatively by the agronomist and the animal husbandman. This plan need not be unduly expensive. It should be carried out in a simple, thorough way. Any studies which are made should be made under field conditions. They should be systematically located and carried on at a sufficient number of points so that the influence of different types of soil, topography and climate will receive adequate attention. Furthermore, there should be such a co-ordination of effort that the results obtained at any given point will shed light on the problem as a whole. We are all agreed, I take it, that the problem is urgent. It is therefore necessary that results be obtained promptly which will answer the questions of most pressing importance in a minimum of time. No plan should be adopted which will necessitate a large amount of preliminary detail work in the way of providing equipment and facilities. Sufficient numbers of cattle should be used to make each experiment in itself of commercial importance. That is to say, in the case of stockers, the number should be at least a carload in every experiment; in the case of studies on the maintenance of a breeding herd, a herd with a minimum of at least fifty cows, should be used, so that at least a carload of cattle would be produced by each breeding unit each year. The methods and equipment used should be such that successful results can be immediately applied to the business on a large scale. The experiments should be planned primarily from a business standpoint, and none should be attempted which do not promise in all probability, under competent management, to show a profit. All records should be kept with systematic care and precision by the methods now commonly accepted as standard for such work. The record keeping feature of the work is not properly chargeable against the cattle on experiment and constitutes the principal item of overhead expense. Properly handled, the receipts from sales of cattle used 
in such a series of experiments can be made to pay a large proportion of the expenses of the work.

The Chairman: Are there any inquiries?

A Delegate: Is it necessary to stable cattle in the South?

Mr. Rommel: Not necessarily. It is always an advantage to shelter cattle in storms. I have always insisted on this: If you give an animal a dry place to sleep, shelter from the storms, and plenty to eat, you will get along all right through the wintertime; and all you need is a simple shelter for the cattle, as they ought to have a dry place to sleep, and where they will not be exposed to storms. These storms which you have down here are almost as severe on the cattle as the more severe storms in the more northern sections.

\section{A Survey of the Live Stock Situation}

\section{By Dr. Andrew M. Soule President of the College of Agriculture of the State of Georgia}

Statistics are unpalatable to the average man. They do not seem to appeal to his imagination. They are too matter of fact and not sufficiently spectacular to interest him. Yet their consideration is basic to ascertaining the true status of any business or industry. The general dislike for statistics is in large measure due to the difficulty of their ready assimilation. To understand them requires careful study, and this the average farmer or business man has not been ready to bestow upon them, because like the English, he has always muddled through somehow. This False Philosophy Dangerous indifference to statistics accounts in large degree for our woeful lack of a proper appreciation of the true economic situation which confronts us as a people. We are surprised and startled when we learn that the food supply has become circumscribed and that the cost of living has advanced in such an alarming manner. It has been much easier in the past to follow the false reasoning and "spread-eagleism" of the orator or to swallow bodily the absurd 
explanations offered by the demagogue until at last we have reached a point where these things no longer act as palliatives and we are face to face with the necessity of studying and solving economic questions through the exercise of the highest intelligence and skill which we as a nation are in position to bring to their correct solution. I have no apologies to offer, therefore, for the statistical data presented in this paper, as I consider it necessary to the elucidation of the discussion which follows.

A survey of the live stock situation must, of necessity, deal with the past, present and future conditions and possibilities of this industry in the South. In this connection, it is proper to state that this discussion is based on a consideration of the number of live stock held on the farms in the following fifteen states as taken from the 1910 census: Maryland, Virginia, West Virginia, North Carolina, South Carolina, Georgia, Florida, Kentucky, Tennessee, Alabama, Mississippi, Arkansas, Louisiana, Oklahoma and Texas.

\section{Animals in Southern States 1910.}

The South's

Part in the

Nation's Live

Stock Industry
Number

Dairy cows. . . . . . . . . . 5,651,000

Other cattle. . . . . . . . . . 13,795,000

Sheep. . . . . . . . . . . . . . . . . 7, 196,000

Swine. . . . . . . . . . . . . . 18,374,000

Total. . . ..........45,016,000

Animals in United States 1910.

Number

Dairy cows. . . . . . . . . . . 20,625,000

Other cattle. . . . . . . . . . . . 41,178,000

Sheep. . . . . . . . . . . . . . . . 52,447,000

Swine.
Value

$\$ 149,462,000$

$216,993,000$

$25,574,000$

$80,670,000$

$\$ 472,699,000$
Value $\$ 706,236,000$ $793,287,000$ $232,841,000$ $399,338,000$

Total.

$\$ 2,131,702,000$

It appears that in 1910 , there were $45,016,000$ head of live Live Stock stock, worth $\$ 472,699,000$, owned on Southern farms. At that Values Double in Six Years

time, there were $172,435,000$ head of live stock on all the farms in the United States, worth $\$ 2,131,702,000$. It appears that a little more than one-fourth of the live stock owned in the United States 
was in the South, while they had a value of less than one-fourth of the total value of all the animals owned in the United States.

On January 1, 1917, according to the Bureau of Crop Estimates, the live stock in the Southern states numbered $48,171,000$ and were worth $\$ 877,643,000$. The number of animals in the United States was $179,553,000$, worth $\$ 3,961,527,000$. There was an increase for the country as a whole, therefore, in numbers, of $7,118,000$, and in value, of $\$ 1,829,825,000$. In other words, while the increase in live stock as a whole is relatively small, the value almost doubled.

Animals in the Southern States 1916.

Number

Dairy cows. . . . . . . . . . . . . 5, 5,889,000

Other cattle. . . . . . . . . . . . . 13,005,000

Sheep. . . . . . . . . . . . . . . . . . 6,978,000

Swine.
.22,299,000

$48,171,000$
Value $\$ 276,085,000$ $365,747,000$

$37,047,000$ $198,764,000$

$\$ 877,643,000$

Animals in United States 1916.

\section{Number}

Dairy cows. . . . . . . . . . . . 22,768,000

Other cattle. . . . . . . . . . . . . 40,849,000

Sheep. . . . . . . . . . . . . . . . 48,483,000

Swine. . . . . . . . . . . . . . 67,453,000
Value $\$ 1,358,435,000$ $1.465,786,000$ $346,064,000$ $791,242,000$

$\$ 3,961,527,000$

During the six years under discussion, the number of animals in the South increased by $3,155,000$, as compared with $7,118,000$ for the United States. There was also a very substantial increase in value, amounting roughly to $\$ 405,000,000$. In the matter of gain in numbers, the South more than held its own, but did not make much progress as compared with other sections of the country in an increased valuation of its live stock. An analysis of the figures shows that there was quite a substantial gain in the Swine as a Mortgage Lifter number of dairy cows, amounting to 238,000 head. In the number of beef cattle there was a loss of 790,000 head. Sheep also declined by 218,000 . Hogs increased by $4,025,000$ head. It is gratifying to observe that the hog industry is being recognized at 
Decline in Beef Cattle and Shecp

Room for $150,000,000$

Sheep in the South its face value, and that this line of animal husbandry is being systematically advanced throughout the South. The hog is a mortgage lifter in the truest sense of the word, and will pay the farmer as large a return on his investment in as short a time as he can obtain from any other class of stock. As a means towards increasing the food supply and adequately feeding our own people, building up the income of our farms, and enabling us to diversify and rotate our crops in a satisfactory manner and reduce or overcome the losses which the boll weevil may cause in various states, let us encourage swine husbandry in every legitimate manner. - If we do this, many of our most difficult problems will be satisfactorily solved.

It may be surprising to many that there should have been a decrease in beef cattle of 790,000 head. This is a grave economic mistake and must be corrected if the South is to become permanently prosperous and successful. It is all the more regrettable that this decrease in beef cattle should have occurred in view of the great success which has attended the campaign for tick eradication, and the relatively large area which has been set free as a result of this work which has been carried forward by the federal Bureau of Animal Industry, in co-operation with the several states. The decrease in the number of sheep on Southern farms is also to be greatly regretted. There is no explanation for such a condition save the fact that the worthless cur has been allowed to flourish at the expense of the "golden hoof" of the sheep. In England sheep are grown by the millions on lands similar to thousands of acres unadapted for general cultivation to be found in the South, yet which are susceptible of producing a fine variety of grass and forage crops. In England sheep are raised for mutton and the wool is a surplus crop. There is no reason why this industry should not be established on similar lines in the South. Where Great Britain, with an area of 120,000 square miles, maintains, roughly speaking, between twenty and twentyfive million head of sheep, we in the South are maintaining less than seven million on 899,747 square miles. On a comparative basis, the South should be maintaining over $150,000,000$ head of sheep, or between five and six for each inhabitant. At the present time, England is maintaining one sheep for each two of her population. Is it any wonder that the cost of living should be rapidly increasing; that meat should become in some senses of the word scarce and so high-priced that the average individual cannot use 
it freely; or that the cost of woolen clothing should reach such exorbitant figures? The writer likes dogs, believing them to be one of the most wholesome and desirable of all pets, but the dog should not be given free range to destroy what should be one of the country's most important industries. We have literally thrown sheep to the dogs. When will we come to our senses and confine or destroy the worthless cur and give the golden-hoofed sheep a chance to aid in the agricultural emancipation of the South and in the restoration of much of our worn and gullied lands which now lie practically idle? Surely this situation can not continue much longer. It is too much out of joint with the times. Surely some Moses will arise to lead us to see the light and act in a rational manner towards the solution of this question and the establishment of sheep husbandry on some basis commensurate with our opportunities and the needs of the South and the nation as a whole.

The question naturally arises as to the relation of animal husbandries in the South compared to the population as a whole. In other words, what are we doing towards providing ourselves with animal food as compared with other sections of the country? As already pointed out, the area of the fifteen southern states is 899,747 square miles. The area of the United States is $3,026,789$ square miles. The South, therefore, comprises practically onethird of the total area of the United States. In 1910 the population of the United States was 91,972,266, and of the South, $28,855,939$, or a little less than one-third of the total population. We possessed, according to the figures of 1916, about one-fourth of the dairy cows, about one-third of the beef cattle, about oneseventh of the sheep, and about one-third of the hogs owned in the United States. Therefore, in spite of the substantial increase shown in the number of swine in the past six years, we are barely holding our own in the matter of maintaining our animal industries as compared with the rest of the country. It behooves us to realize this situation and take steps to avert the crisis which will shortly confront us unless something radical towards encouraging and developing our live stock industries is accomplished very soon.

The population of the United States in the last sixteen years has increased by more than $26,000,000$, or 33 per cent. In the past six years, it is believed that the numbers have increased by more than $10,000,000$. There has been no such proportionate

Warns South of Food Crisis
Throwing
Sheep to the
Dogs 
increase in the number of our farm animals, yet meat and dairy products constitute 37 per cent. of the average diet, cereals 31 per cent., sweet and Irish potatoes 13 per cent., vegetables 8 per cent., and fish 2 per cent. The amount of beef, veal, mutton and pork available per capita has fallen from 248.2 pounds in 1899 to 219.6 pounds in 1915. The production of butter and cheese per capita has fallen from 23.6 pounds in 1899 to 21.1 pounds in 1909. The production of fish, cereals and Irish potatoes has fallen off since 1899, while poultry, eggs, sweet potatoes and citrus fruits have shown an increase, which, of course, is very encouraging insofar as it goes. Under the stimulus of war abroad and extraordinary prices, the exports of meat products for 1916 will prob-

Heavy Exports to Continue After War

Tick Eradication First Essential ably be $2,000,000,000$ pounds, together with $602,000,000$ pounds of fats and oils. The imports of these two items amount to practically nothing as compared with the exports. Hence, we face another danger of decreasing our meat supply through the demand abroad, which it is reasonable to suppose will continue until the end of the war and for some years thereafter. This is but an added reason why we should develop and promote our animal industries in every possible way. Feverish activity along this line is what we need. At the same time, we should avoid a boom or speculation or irrational development because all of these things will re-act unfavorably on the industry in the long run. At the same time, it does not appear that the Southern people as a whole realize the true inwardness of the existing situation or fully appreciate the opportunities which it offers to them.

Among the things which need to be done to place our animal industries on a thoroughly constructive basis is the complete eradication of the cattle tick. Commendable progress is being made along this line. This work was begun in 1906, through the efforts of a small group of men associated with Southern agricultural colleges and experiment stations, and if laurel wreaths were given to those deserving them, theirs wonld have been bestowed long ago. At a time when everyone considered the eradication of the cattle tick a dream of the imagination, these men. inaugurated the work on a scale which demonstrated its feasibility, and through persistent effort, won the sympathy and approval of Secretary Wilson, Congress and the Federal authorities to the support of this work. The South will never be able to pay the debt of gratitude it owes to Dr. Tait Butler, Prof. H. A. Morgan. 
Prof. W. R. Dodson, Prof. B. W. Kilgore, Dr. Cooper Curtis and the other men who were associated with them in the inauguration of this wonderful enterprise. Already ticks have been eradicated from 294,014 square miles of territory since 1906. In other words, over forty per cent. of the originally infested territory has been cleaned and forever rid of this miserable parasite which caused losses estimated at $\$ 40,000,000$ a year to the live stock owners of the South. In Georgia, for instance, fifty-five counties are now free of ticks and quarantine regulations are being enforced in thirty-eight others. It is only a matter of three to five years until practically every one of the infested states will have been cleaned up, and when that time is reached, the Southern stockmen ought to join in a grand jubilee of thanksgiving.

Next to the eradication of the tick, efforts should be made looking to the checking and elimination of disease and parasites. For instance, much can be done towards reducing losses from hog cholera which amount now to millions of dollars annually. Tuberculosis can also be controlled and in large measure, stamped out. This disease causes a loss in the United States of $\$ 25,000,000$ a year. According to the following table, the losses of live stock in Georgia, mainly from disease and exposure, may be conservatively estimated at $\$ 5,247,520$. The total number of animals lost in the year indicated was approximately 269,480 head. Of this number 258,480 ; were meat-producing animals so that the losses resulted chiefly in cutting down the meat supply and increasing its cost to the consumer.

Losses of Live Stock in Georgia for Year Ending April 1, 1916.

Number.

Horses. .......... 11,000

Cattle. . . . . . . . 41,800

Sheep. ......... 5,560

Swine. . ..........211,320

Total. . .......269,680
Disease and

Parasites

Cause Heavy

Losses

Applying these figures to the South. it will be seen that for the fifteen Southern states the losses amount to between 75 and 100 million dollars annually. Surely, it would be worth while on the part of the different states to spend something for educaMore Veterinarians tion, and thereby train a generation of veterinarians so that the Needed 
stockmen might have their services at a reasonable cost. The stockman himself should receive sufficient training to be able to diagnose many of the more important diseases and give the necessary treatment. This is particularly true in the case of swine, which the farmer can successfully inoculate against cholera. We have not realized the nature or extent of these losses as land owners, and certainly the consuming part of our population have not understood the situation or they would have demanded a measure of relief along the lines indicated and which can only be done through the medium of the more liberal endowment of our agricultural colleges and the training of experts to perform the necessary public service welfare work with animals. We also need to educate a generation of stockmen. The stock business is a comparatively new industry. It is much more complicated than that of cotton farming. When one comes to deal with living animals, subject in many respects to the same diseases and troubles which afflict the human race, skill in management, feeding and handling becomes absolutely essential. A live stock husbandman is not made over night. The successful feeders and breeders of England and Scotland have followed the industry from generation to generation. The owners of breeding animals in those countries are highly educated and scholarly men, and they have the most reliable and capable herdsmen with wide experience in the handling of animals in charge of their herds and

The Agricultural College as a Factor flocks. We must, therefore, encourage our boys to go to agricultural colleges and obtain the fundamental and technical training necessary, and then arrange for them to obtain such additional practical information as may be necessary on selected stock farms. When this is done we will have started the industry on the high road to success, because it will have been established on a correct scientific basis, which is the only lasting foundation on which to build any superstructure.

That we need education along this line more than in other sections of the country is evidenced by the fact that 25 head of cattle out of every 1000 die from disease and 25 from exposure; 31 sheep out of every 1000 die from disease and 31 from exposure; 71 head of swine out of every 1000 die from disease. These figures apply to the Sunny South, with an equable climate, long growing season and the other favorable conditions which pertain here. On the other hand, in the North Atlantic states, where seasonal and climatic conditions are as unfavorable as 
they could be in any section of the United States, only 19.9 cattle in 1000 die from disease and 3.6 from exposure; of sheep 25.2 die from disease and 9.2 from exposure; of swine 27.5 die from disease.

That we can make rapid and substantial progress if we apply ourselves to the task properly is shown by what has been accomplished in Georgia in the last few years. According to the census figures of 1910 we possessed animals of the several classes Georgia an Example to the South to the number and value indicated below:

\begin{tabular}{|c|c|c|}
\hline & Number. & Value. \\
\hline Horses. & 120,067 & $\$ 14,193,839$ \\
\hline Mules. & 295,348 & $43,974,611$ \\
\hline Beef and Dairy Cattle........ & $1,080,316$ & $14,060,958$ \\
\hline Sheep. . ................ & 187,644 & 308,212 \\
\hline Swine. . & $1,783,684$ & $5,429,016$ \\
\hline Total & $3,467,059$ & $\$ 77,966,6$ \\
\hline
\end{tabular}

According to the Bureau of Crop Estimates the figures for 1916 are as follows :

Number.

Horses

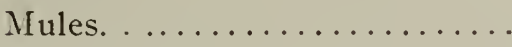

Beef and Dairy Cattle....... 1,104,000

Sheep. ...................

Swine.

Total.
127,000

324,000

150,000

$2,585,000$

$4,290,000$
Value.

$\$ 16,383,000$

$52,812,000$

$26,579,000$

420,000

$23,265,000$

$\$ 119,459,000$

The increase in numbers for the period mentioned amounts to 822.941 and the increase in value to $\$ 41,492,364$. Part of this increase in value is attributable to the better grade of live stock and the higher market values pertaining, but a very considerable amount of it is due to the greater number of animals now owned. For instance, horses and mules show an increase, beef and dairy cattle a slight increase, sheep a falling off, but swine an increase of 801.316 , or well on towards the million mark. This is a very notable increase to have occurred in a period of six years. Moreover, where these animals had an average value of $\$ 3.04$ in 1910 , they now have an average value of $\$ 9.00$, showing that the quality has been greatly advanced. In other words, the increase in 
value of swine in Georgia in six years amounts in round numbers to about $\$ 18,000,000$.

This gives some idea of the forcefulness of an educational campaign organized and conducted along certain lines. While all of the increase is not attributable to any one agency, the boys' live stock clubs have exerted a marvelous influence by creating a renewed interest in swine husbandry in inducing the fathers to purchase pure-bred animals for them, and thereby raising the

Boys' Live

Stock Clubs and County Agents

Praised

Grass a

Friend and Asset to the Farmer quality of the stock kept on many farms. Naturally, the various organizations concerned have endeavored in every way to encourage the use of preventive serum, with the result that large numbers of outbreaks of this disease have been checked at the start, and hundreds of farmers taught how to use the serum properly. The county agents are undoubtedly to be credited with having accomplished a work along this line worth millions of dollars to the swine owners of the state. They were the men on the ground when the outbreaks occurred and their prompt action and public service work in this direction cannot be too highly commended. I have no doubt but that they have done an equally important work in every other Southern state.

Among the things which must be done is to teach the Southern farmer to quit fighting grass. Grass should be his most valuable friend and most highly prized asset. The cotton farmer has been taught to fight grass from infancy; therefore, it seems that he is unwilling to have any of it on any part of his land whether he devotes it to cotton or not. One can not grow and maintain live stock successfully without grass. It is needless to enter into detail as to the great variety of grasses and clovers which may be provided for summer and winter grazing and which would shortly clothe our hills and prevent their erosion if given opportunity to do so. They would also add materially to the carrying capacity of the land, shorten the length of time we would have to stall feed our animals, enable us to improve the quality of our live stock, and give us the necessary succulent food for the cheap maintenance of live stock in the summer which silage affords in the winter.

Speaking of the educational campaign, it is proper to state that hundreds of silos have been built in Georgia in the last few years as a result of the work done by the animal husbandry division and the extension force of the State College of Agriculture. Plans have been furnished to thousands of farmers and they have 
been aided in erecting the necessary structures. They have also been advised as to the crops to grow and as to the methods of feeding to follow, with the result that the silo is now regarded by many as an indispensable factor in the maintenance of beef and dairy cattle on an economical and practical basis. Only a beginning has been made in this direction, however, for the time nuust shortly come when there will be thousands upon thousands of silos in every Southern state if we are to develop our live stock business to the degree which is necessary and essential.

Only a word can be said in this connection relative to the feeding of live stock, but it is along this line that more failures are recorded than in any other direction. Self-criticism is not pleasant, but if we realize that for the most part we are "babes in the woods" when it comes to the question of feeding, we will make progress all the more rapidly. The problem of animal nutrition is a complicated one from every point of view. One must understand the composition of foodstuffs, and the anatomy, physiology and requirements of the animal body for maintenance, for growth and for work. One must understand how to combine foods in order to promote digestion and circulation; in other words, how to lubricate the machine most cheaply and successfully. The animal in the stall corresponds to the knitting machine in the mill. It may or may not do effective work. It all depends on the manner in which it is set up and manipulated. It must be adjusted and oiled and lubricated. The animal must be fed and watered and cared for properly if expected to produce a profitable return. As to the amount of foodstuffs available, our supply may be limited in some respects, but we can produce silage ad libitum, and this can be fed with success for six months of the year. Summer pastures can be provided by the farmer who has the ambition to do so. Grain crops of a great variety may be had to use as concentrates. We can increase our yields of corn, oats, peanuts, soy beans, velvet beans and cotton seed meal. No section of the country may be better supplied with the variety of foodstuffs essential to the proper nourishment of all classes of live stock than the South. It is a question of choosing from the rich field of possible supply and combining nature's gifts in the proper manner.

That the feed problem is a determining factor in economic production is shown by the following example: A dairy cow fed on a ration of 36 pounds of silage and 6 pounds of cotton seed

Helping the Farmer Build Silos

The Science of Proper Feeding 
Rations That

Double

Profits

High - Grade

Cows Pay

Best in the

End meal produced a profit of $\$ 51.75$ from butter when sold at 30 cents a pound. When fed on a ration of 36 pounds of silage, 7 pounds of hay and 5 pounds of mixed grain, the profit at the same sale price was $\$ 37.15$. When fed on a ration of 12 pounds of silage, 10 pounds of hay and 10 pounds of mixed grain, the profit fell to $\$ 24.43$. In other words, one ration was more than twice as profitable as another. This example will apply with equal force to the economic maintenance of horses and mules, beef and dairy cattle, sheep and swine. The feeding of live stock may be a gamble at present, and, if so, the cards stack themselves against the owner every time. Intelligence and skill and the essential knowledge on which correct nutrition is predicated must be possessed by the successful stockman. I emphasize, therefore, the necessity of encouraging hundreds of boys in the South to take the necessary courses of instruction in our agricultural colleges that they may become acquainted with the science and art of animal nutrition and become experts in the handling of live stock. Until this is done our progress will be of the more or less blundering variety and our losses will be so frequent as to discourage rather than promote what in the very natıre of the situation should always be one of our most important and constructive industries.

The stockman must give consideration to quality in his animals. If he is not willing to do this he cannot hope to succeed. The South is very backward in this direction. We are securing a very small return, for instance, from the dairy cows we maintain. In fact, a large per cent of them are unprofitable. It may not seem credible to every person, but it is true nevertheless that a cow giving 300 pounds of butter fat in a lactation period made the same profit as forty-one cows each yielding 131 pounds of butter in a lactation period. The reason for this lies in the fact that it costs so much to maintain an animal. The food consumed in maintenance is not used for productive purposes. A cow of limited assimilative capacity can only utilize so much food. WVe may feed her more than a given amount but she wastes the balance. She is not an economical manufacturer of milk and butter. We must get rid, therefore, of the thief in the dairy herd, and we should remember that there are thousands of them. The same is true of our beef cattle and our sheep and swine. We must get rid of the scrub stock, the slow developer, and the animal which can not eat an unusually large amount of food and assimilate and 
digest it to advantage and manufacture therefrom some food substance of value to the owner and to the human race. We must come to understand that animals are just as individualistic as huScrub Stock man beings and we must get rid of the low-grade stock we possess if we are to be successful and prosperous as live stock farmers.

The importance of this matter is illustrated in the following table, which shows the average value of different classes of farm animals in Georgia, in the United States, and in the states where the particular class of animals have attained the highest value. Georgia figures have been used because of the readiness with which they may be applied to the conditions prevailing in the other Southern states concerned :

\section{Average Value of Live Stock.}

\begin{tabular}{|c|c|c|c|c|c|}
\hline Horses. & $\begin{array}{l}\text { Georgia. } \\
\$ 127.00\end{array}$ & $\begin{array}{l}\text { United States. } \\
\$ 102.94\end{array}$ & $\begin{array}{l}\text { Values in other } \\
\text { Maine }\end{array}$ & $\begin{array}{l}\text { States. } \\
\$ 152.00\end{array}$ & \\
\hline \multirow[t]{2}{*}{ Mules. . } & 163.00 & 118.32 & New Jersey & 169.00 & \\
\hline & & & Rhode Island & 77.00 & \\
\hline \multirow[t]{3}{*}{ Dairy Cows } & 37.00 & 59.66 & Nebraska & 68.00 & \\
\hline & & & Wisconsin & 65.00 & \\
\hline & & & Illinois & 43.30 & Average \\
\hline \multirow[t]{3}{*}{ Beef Cattle } & 16.20 & 35.88 & Nebraska & 44.30 & Value of Live \\
\hline & & & Montana & 53.10 & \\
\hline & & - & Iowa & 8.80 & \\
\hline \multirow[t]{4}{*}{ Sheep. } & 2.80 & 7.14 & Nevada & 8.20 & \\
\hline & & & Idaho & 8.20 & \\
\hline & & & Connecticut & 17.50 & \\
\hline & & & Newv Jersey & 17.00 & \\
\hline \multirow[t]{3}{*}{ Swine. } & 9.00 & 11.73 & Maine & 16.60 & \\
\hline & & & Iowa & 15.50 & \\
\hline & & & Nebraska & 14.00 & . \\
\hline
\end{tabular}

Dairy cows in Georgia are worth on an average $\$ 37.00$ apiece; in Rhode Island $\$ 77.00$; and in the United States $\$ 59.66$. In Nebraska they are worth $\$ 68.00$, and in Wisconsin. $\$ 65.00$. Wisconsin is one of the greatest dairy states, and one can understand why their cows are so much better producers than ours as shown by their average value. Wisconsin farmers do not come to Georgia or the South to buy high-producing dairy animals, but we go to them for this purpose. There is no reason why, by the use of purebred sires, the elimination of unprofitable animals, and the proper feeding and maintenance of our cows, we should not make

Pure - Bred Sires Mean Successful Farms 
them worth $\$ 65.00$. It should be possible to add several million dollars to the value of our dairy herds every year by the process indicated. In a state like Georgia, for instance, we should be able in large measure to replace the losses which the weevil might inflict on us through the improvement of our dairy cattle. It would not break us to do it. We have the money and the brains and the intelligence. All we need to do is to study this proposition as seriously as we have studied cotton production. Then, educate our boys, use pure-bred sires and utilize the natural facilities which we possess to attain the end in view.

Take the case of beef cattle. They are worth $\$ 16.20$ apiece in Georgia, and in the United States $\$ 35.88$. In other words, our beef cattle are of a low grade. They dress out about 40 per cent of the live weight. It takes them about a year or so longer to mature than it should. They do not finish out advantageously. When shipped to consuming centers they class as little better than scrubs for the most part. In Montana the average beef animal is worth $\$ 53.10$, in Nebraska $\$ 44.30$, and in Illinois $\$ 43.30$. Montana beef cattle are worth more than three times as much as Georgia beef cattle. This has been brought about through the use of the pure-bred sire, the elimination of the scrub, and a state-wide campaign of education.

The facts presented above apply with equal force to sheep and swine. As a result of the boys' pig club work and other educational forces which have been brought into play, swine in Georgia are now credited with an average value of $\$ 9.00$ as compared with $\$ 11.73$ for the United States. In Connecticut they are worth $\$ 17.50$, or almost twice as much as in Georgia; in New Jersey $\$ 17.00$, and in Maine $\$ 16.60$. In this connection it is important to

Natural Advantages of the South remember that the highest priced animals in the United States in many instances are in states which can not produce half as many food crops as Georgia, which do not raise anything like the same quantity or variety of concentrates, and where the climatic conditions are most unfavorable. The people in those states are only able to compete with the South in the production of live stock because of the special study they have made of this business; because of the greater skill and care with which they feed and handle their animals; and because of the high premium they have placed on quality which has been attained through the use of pure-bred sires. These lessons should sink deep into our hearts, because they constitute the keystone over the arch of success as it applies to ani- 
mal production. The foregoing figures illustrate a point which I desire to again re-emplasize in that we can recoup ourselves for losses due to the boll weevil invasion by improving the quality of our live stock and by directing attention to the development of animal industries. There is no reason, for instance, why we should not increase the number of hogs to three million in the course of a couple of years, thereby adding from this source alone several million dollars annually to the revenue of our farms. In the course of four or five years we could increase the value of our beef and dairy cattle by a similar amount, thus giving us in a short time an offset of twenty to twenty-five million dollars to replace any losses incident to weevil damage.

The latent possibilities of live stock industries are nicely illustrated by what has been, accomplished on the College farm at Athens in the past few years. This farm was little better than an abandoned plantation when taken over in 1907 . The figures presented below show the value of the live stock at that time and at subsequent periods up to June 1, 1916:

Value of live stock on College farm Sept. 1. $1907 . \ldots \ldots \ldots \ldots \ldots \ldots \ldots \ldots \ldots \ldots$

$\$ 1,917.00$

Expenditures for live stock from Sept. 1,

1907 , to June $1,1916 \ldots \ldots \ldots \ldots \ldots$

$9,683.60$

Value of live stock June 1, 1916.......\$17,310.00

Sales of live stock Sept. 1, 1907, to June 1,

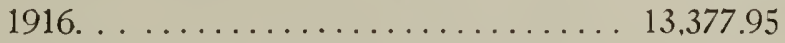

Net increased value plus sales above ex-

penditures for purchase of live stock. .

$19,087.35$

What Has

Been Done on an "Abandoned" Farm

\section{$\$ 30,687.95 \$ 30,687.95$}

Arerage amount expended yearly for live stock....\$\$ 1.075 .95 Average annual sales of live stock............. 1,491.98 Average net yearly increase in inventoried value of live stock.

As is shown, the farm started with $\$ 1,917$ worth of live stock. There has been expended for the purchase of live stock during the past nine years $\$ 9,683.60$. The sales of live stock for nine years amount to $\$ 13,377.95$, while the value of the live stock as inventoried on June 1,1916 , was $\$ 17,310.00$. The net increased value plus sales above expenditures for the purchase of live stock, therefore, totaled $\$ 19.087 .35$. An accurate record of the 
number of animals purchased and handled and the manner in which they have been disposed of has been kept on the College farm since the work was first started. This will give some idea of what can be done on a farm organized along the lines indicated. What has been done here can be done by hundreds of other farmers who will make the business of live stock breeding a specialty and study the various problems involved therein in an intelligent manner. It is worth while noting that while $\$ 1,075.95$ was spent for the purchase of live stock each year, the annual sales amounted to $\$ 1,491.98$, and the average net yearly increase in the inventoried value of the live stock to $\$ 1,710.33$. This is a line of activity which the young men of the South should engage in, and everyone who has the welfare of this section of the country at heart or who is concerned about reducing the cost of living or supplying our markets with an abundance of choice meat and dairy products will lend his encouragement to the promotion of this industry.

It has been thought by many that Percheron mares could not be maintained successfully in the South. On January 1, 1911, a team of grade mares was purchased by the College of Agriculture for $\$ 470.00$. They have done the same amount of

Percheron Mares Successfully Grown in the South

Two - Year Old Hereford Steer Sells for $\$ 123.50$ to the Butcher work as any team of mules would have performed in the past six years. Colts to the value of $\$ 1,137.50$ have been sold from them already and there is a filly on hand worth $\$ 100.00$, making the gross return from these two animals $\$ 1,237.50$, or more than two and a half times their original purchase price. In the meantime they have earned their board and keep. The man who cannot keep Percheron mares on his farm should not attribute it to climatic or soil conditions, but to carelessness in the matter of feeding and general management.

That our beef industries can be rapidly and profitably built up is illustrated by the fact that a long 2-year-old grade Hereford steer weighing 1,450 pounds was recently sold to an Athens butcher at 8.5 cents a pound net, or for $\$ 123.50$ cash. This steer was two crosses removed from a native cow that cost $\$ 17.00$. It took a little over six years to produce him. When slaughtered he dressed out 64 per cent of valuable meat. He cost the butcher 11 cents a pound dressed. The same butcher purchased a carload of steers at 5.5 cents. They cost him hung up on the hooks 10.75 cents a pound, but the high-grade Hereford steer sold for 5 cents a pound more all around, and hence he was a far more 
profitable animal to handle. The butcher who purchased him with misgivings has since visited the College and wants to know when we will have some more like him. He has been educated and has learned that quality is a matter of surpassing moment in animals. Persons who ate the meat are anxious for some more of the same character. There are 100,000 farms in the South where the same class of animal can be produced under the same conditions in a period of six years, starting with a pure-bred sire on native stock. It may be interesting to know that Hereford steers sold as long yearlings by the College attained an average weight of 1,010 pounds and sold at $\$ 80.50$ a head cash on the farm.

There never was a country offering greater opportunities to live stock men, but in this connection it should be remembered that it takes a keen, analytical, constructive business man to run a live stock farm just as well as it does to run a law office, a hardware business or a manufacturing enterprise. If this fact can be borne into the consciousness of our people the foundation will have been laid on which to build up animal industries Business Methods Needed in of proportions calculated to serve the present and future ecoLive Stock Farming nomic needs of the South, and to a reasonable degree, the nation as a whole. 


\section{The Animal Industry of the South-Past, Present and Future}

\section{By Dr. W. H. Dalrymple \\ Professor of Veterinary Science, Louisiana State University and A. \& M. College}

The subject assigned to me, or rather to that distinguished scientist, Dr. Jno. R. Mohler, Assistant Chief of the Federal Burean of Animal Industry, whose place I am presumed to fill on the programme, is a very large one, and one that it would be impossible to adequately cover in the limited space of time allotted to its discussion.

As regards the past of animal industry in the South, I do not believe it would aid us much at this time to dwell to any extent on the conditions that are behind us, unless it should be to utilize our remembrance of them, along with what we know of the present, to help us build more solidly for the future.

There is one thought, however, which appeals to me very

Stop "Playing With Agricullure" strongly, viz., that if we expect to make the most out of our great agricultural and live stock possibilities in the future we will have to consider and treat them in a much more serious manner than has been the case in the past, or as some seem to view them even at the present time.

Or, to quote a recent remark made by a prominent British agriculturist, as he views matters at the present time in that country, and which, in some degree at least, may apply to us, viz., "We can play with politics, with industry, with law, and even with the consuming fires of civilized (?) warfare, but if we value the future of our country, and of our race, we cannot any longer afford to play with agriculture."

The great cattle ranges of the West are rapidly being placed under cultivation to meet the demands of an ever-increasing population, both natural and through immigration, and which may be largely added to after the world is again at peace, who have 
to be provided with occupations, and whose stomachs have to be filled. In fact, one of the greatest economic problems confronting us at the present moment is, how to increase the producing capacity of our soils, and extend our cultivable areas to the ut.most, even to our home gardens and backyards, not only to keep pace with our present-day requirements under normal conditions, but to meet a most abnormal state occasioned by our participation in a world's conflict. The call for the highest standard of efficiency in the production and conservation of food does not come only to the American farmer, but the cry today comes from everywhere, for the mobilization of the world's agricultural resources, so that the people of different continents may not suffer for lack of the necessities of life.

For some time, however, we have been brought face to face with the problem of the high cost of living, even before the present international crisis became so acute, and we have heard of many attempts, theoretical and otherwise, to reach an intelligent solution. Might we not, with appropriateness, ask ourselves the question: If agricultural conditions in the South had, all of these years, been in keeping with her possibilities, in the production of the daily necessities of our people, in the matter of food supplies, both animal and vegetable, would conditions, as we find them today, have been likely, even with the world in a state of war? I am inclined to think not!

I believe, however, that the South will, before many decades have passed, be the great stock-raising section of the country, more particularly the meat-producing animals, and will, after we stop "playing with agriculture," be able to furnish both food for our people and enough, and to spare, of the feed crops necessary to develop and maintain a largely increased animal population. In short, it is our belief that, ultimately, the South will have to The South as the Nation's Hope come to the rescue in preventing the risk of any serious break in the equilibrium of our food supply, should that ever occur: and I also believe that she will be fully equal to the occasion.

Up to the present, however, and in a general way, our Southern country has not even approached the point of maximum production, either in food crops, or in the number or quality of our live stock, to be able to successfully compete with other more advanced sections in the great metropolitan markets. And even if she had, especially in her cattle production, there are

World Demands More Food 
The Tick a Disappearing Menace

considerable areas from which her animals would be excluded from such markets because of Federal restrictions imposed on account of the presence of that most expensive pest, the cattle tick.

It is gratifying to know, however, that total extermination of this parasite is a question of only a few more years of cooperative effort; and its accomplishment lies at the very foundation of our general agricultural prosperity in the future.

True, the cattle tick has militated very seriously against our progress in the production of improved cattle; but our chief obstruction, which I believe is now generally conceded, has been our almost universal system of single-cropping.

Doubtless, and on account of the world-wide need for cotton, this system has, temporarily if you will, brought large returns to our people.

But, under such a system, in which every other necessity of the farm and home has had to be purchased and paid for out of those returns, has the fertility of our soils been increased; has it increased their power to produce, or otherwise enhanced their value? I think not!

On the other hand, had our general farming system been more along the lines of diversification and crop rotation, including cotton, necessarily, and, of course, live stock, and with intelligent fertilization, with increased yields of both cash crops and those for consumption by our farm animals, and with a sufficiency of the latter crops to bring to prime market condition the meat-producing animals, such as cattle, sheep and hogs, and through them to market the farm feeds and forages at enhanced values, conditions might have assumed a very different aspect. In short, had such conditions prevailed, these many years, and with the South on equal footing with other sections of the country, with reference to our great markets, is it reasonable to presume, even under present abnormal conditions, that the cry about high-priced necessities would have had to be so vigorously proclaimed all over the land?

Now is Time for South to Act
But up to the present time it may be said that the South has scarcely been reckoned as among the purveyors of the nation's food supply.

This condition, however, has got to change; in fact, is doing so gradually, if not as rapidly as perhaps one could wish. At the same time, it is our humble, but candid, opinion that by 
taking full and immediate advantage of present opportunities, and with the further possibilities incident to the utilization of our extensive areas of unused and uncultivated land, the South, in a reasonably short period of time, should not only be able to clothe our people with her cotton and wool products, but should have a large share in the feeding of them with the cereals and their by-products, and with toothsome meat from her well-bred, well-fed, and high-grade cattle, hogs and sheep.

We occasionally hear the remark that the South is a splendid "poor man's country," on account of the ease with which a living may be made.

Such a statement might be construed into a reflection upon our past, or, in some cases, our present, farming methods. And yet it is a most eloquent indorsement of the fertility of our soils that they have been able to even support such methods. But what would be the result did our lands receive the treatment which would be bestowed upon them by a more intelligent system of husbandry; where the farmer made a more thorough study of his profession or calling; made a business of farming rather than a means to eke out a mere existence; who built up his soils; aimed at maximum production; varied his products, both in field crops and in live stock; kept up with the markets; rotated his crops, and strived to produce nothing but the very best his land would yield, and that the market demanded? To try to even picture to ourselves the prosperity of our Southern country under such conditions would be practically impossible.

And, yet, it is just such conditions that we must aim to realize, if we may hope to obtain to the full the results which our opportunities and possibilities have placed within our reach.

Live stock is an absolute necessity on every well-regulated farm, not merely out of sentiment, as some still seem to think, but as a necessary adjunct to the business, that can be employed as local factories, if you will, through which the cheaper raw materials grown may be converted into high-priced finished products, in the form of high-class beef, mutton, pork, etc., which can be marketed "on the hoof."

In fact, one could scarcely imagine a more inharmonious enterprise, or a more discordant undertaking, than an otherwise modern farm holding without its due quota of improved live stock of different varieties.

South a Land of Infinite Possibilities.

The Necessity for Live Stock 
And yet, even today, it is not an uncommon sight to see nondescript animals occupying valuable space. on many of our farming properties, that are forced to eke out a precarious existence, as best they can, or die in the effort.

We all must admit, however, that the climate of the South is ideal for live stock husbandry, in all of its departments, from the growing of the food crops to the finishing of the product for market.

Forage Crops Abundant

Many Useful By-Products
Forage crops, in great variety, grow with a luxuriance that would "tickle the palate" and "whet the appetite" of the most fastidious and epicurean of our herbivorous animals.

Among the legumes, it is only necessary to mention alfalfa. which may be used for grazing, for soiling, or for hay. Lespedeza, our great Southern clover, which makes a most valuable hay, and enhances the value of our pasture when mixed with our native grasses. The cow pea, the soy bean, the velvet bean, the clovers and some of the vetches, etc., all furnish abundant and nutritious food for live stock.

In short, the South has, or can have, a superabundance, both as to quantity and variety, of these most valuable nitrogengathering, soil-improving, and protein-producing forages, so important for the upbuilding and maintenance of soil fertility, as well as the nutrition of animal life on the farm.

In some sections of the South pasturage may be secured practically the year round by sowing almost any of the small cereals as catch crops, after the staple crops have been harvested. which yield abundantly during the fall and winter months, and furnish succulent food at a season of the year when such is in greatest need.

Silage crops, also, in addition to corn, such as sorghum, etc., and root crops of different varieties, produce with great abundance, and may be used to supply excellent succulent feed for cattle, hogs and sheep, after ordinary pasturage has been depleted by the summer's grazing.

But while that which we have enumerated might appear as more than sufficient to meet all practical needs in the matter of live stock feed production, it is by no means all. In addition. there are the important by-products from our cotton fields; and in some parts of the South, those from our rice industry, and from our sugar cane fields and factories. 
With such possibilities, then, in our feed production, our abundance in cereal crops, our many nutritious hays, and other roughage supplies, our winter pasture crops and natural grazing, although much of the latter is yet to be availed of, and in the rich concentrates in the by-products of our cotton, rice and sugar, if the future of stock raising in the South should not appear bright, even to the most casual observer, one is inclined to wonder where else he would go to satisfy his desires in that branch of husbandry.

That all varieties of farm animals do well in the South, it is only necessary to state that all of the principal breeds, and kinds, are already represented, including horses and mules, beef and dairy cattle, hogs and sheep. And not only so, but each has its organizations, in the different states, specially devoted to improvement and greater development of the breeds.

In addition to the increasing interest being displayed in our live stock production, most, if not all, of the Southern states have taken steps to protect, from the ravages of fatal animal diseases, this important industry. I refer to the enactment, by the different states, of suitable live stock sanitary legislation, and the creation or appointment of boards or commissions to see that it is carried into effect.

Such legislation not only affords protection to the live stock interests of a state, but it gives encouragement to prospective immigrants who expect to make the production of live stock a feature of their farm practice.

There is one very important project, vitally connected with the live stock business, which should not be overlooked in these remarks.

Providing Markets for live Stock

Hitherto, one of the chief drawbacks to the live stock industry, especially in the more southerly states, has been the inaccessibility of the best markets, which has militated considerably against the more profitable disposal of stock, and, necessarily, has discouraged many producers.

This unfortunate state of affairs will very shortly be corrected, however, by the erection and establishment of a large packing plant in the city of New Orleans, which will be operated by the enterprising firm of Morris \& Company.

Such a plant will not only care for a large amount of our surplus stock, but will afford an immense stimulus to greater

Legislation Fosters Live Siock Raising 
and better production on the part of our people; and we trust will prove entirely profitable to those responsible for the establishment of the new and important enterprise.

I believe all of us must be convinced of the South's unex-

Every Facility Available

celled possibilities in live stock production, of which many of our people have already taken advantage, with profit to themselves.

We already have an abundance of food materials for animals that would surprise even a Northern or Western stockman, and these are capable of large increase.

We have broad acres of unoccupied fertile lands which simply await the touch of the intelligent husbandman in order to spring into full fruition, and add more wealth and prosperity to our Southern country.

We have representatives of almost every breed and variety of live stock, and an increasing interest constantly being manifested in their greater development.

We have adequate legislation, in practically all of the Southern states, to afford protection against the fatal diseases to which farm animals are susceptible, and which gives encouragement to those engaged in the industry.

We have our State Boards of Agriculture to look after and foster the industry from the standpoint of the state.

We have our State Colleges of Agriculture and our Experiment Stations, and our various branches of Agricultural Extension Service, all bending their efforts to educate and inform our citizens, and encourage and increase interest in this great work.

In short, we not only have the materials to work with, but, in addition, various and important agencies laboring, in an educational way, for the good of the cause; and which are being more and more taken advantage of by our people, and through which advancement is being made.

And we now have one of the most valuable aids to the stock Cheap Money grower in the development of his industry, viz., the privilege of a Help the use of money, which he may obtain on reasonable terms, through the medium of the recently established Federal Farm Loan Banks.

One would naturally imagine, therefore, that all of the needs of the South had already been amply provided, and that nothing more was necessary but to go ahead and prosper; and in a meas- 
ure that is quite true. However, while possession of the raw material is of the first importance, we cannot expect to make the most out of it unless we intelligently employ the appropriate tools or machinery through which to bring it to a state of perfection in the finished product. And so it is with our possibilities; they are not going to benefit us as they should unless we use every effort, and take advantage of every opportunity, to develop them to their highest state of perfection.

In emphasizing one or two of our most important needs, as I see them, I will say, in the first place, that we must double our efforts to wipe the cattle tick from off the map of the Southern states. This is a fundamental necessity in connection with the future success of our cattle industry at least, and that is perhaps the most important.

In the second place, we need more and better live stock through which to market our food crops, and help increase and maintain the fertility of our lands; and we need our own people to devote more time and study to the rational and business sides of animal husbandry and general farming.

In the third place, we need an open market, anywhere and everywhere, and at all times, especially for our cattle, which will depend solely, however, upon the total extermination of the cattle tick from the Southern states, and upon which, likewise, depends the improvement of our cattle, through the influence of improved animals, particularly males, that can then be imported from the best herds of the country; and

In the fourth place, we need more immigration of the desirable, intelligent and industrious farmer-stockman class, whose life and business experience have hitherto been devoted to the branches of stock raising and general agriculture, which we believe the South stands in greatest need of, at the present time, for her general agricultural upbuilding.

Good object lessons are, in great measure, what we require; and this is, I believe, the kind of help we need, and want, to assist us develop our great natural resources, and, as we all believe, our unparalleled possibilities.

Present Encouraging and Future Bright

In summing up, therefore, I believe we can pass over the past of the live stock industry of the South; but we can say that the present is encouraging, and that the future seems bright. 
At this momentous period of the country's history, in fact, in the history of the world, I would like to close with a brief statement.

Owing to the unfortunate international conditions existing, the cry of the world today is for food, and yet more food; and just how long this cry may last, from both combatant and neutral peoples, it is impossible at this time to form anything like an accurate conception.

The man on whom the world has always had to depend for its food supply, and the only one who is now able to satisfy the present. and perhaps future, demand for the necessities of life in the matter of food, is the Farmer. The farmer, therefore, who puts forth his utmost effort to make the proverbial two blades of grass grow where only one grew before, is just as much a patriot, and defender of his country, as the private in the trenches, or the "jackie" on the quarter-deck.

Consequently, and as an imperative national duty, it should behoove every owner and occupier of land to utilize, to the very utmost, every available inch, so to speak, in the production of more and more food, both for man and beast, in order that not only our own people, but the world at large, may not continue to suffer in consequence of any shortage; and in order that our producers may be stimulated to maximum efforts in this direction, and that they may not be forgetful of their responsibilities, they should keep continually reminding themselves, by having emblazoned on their banner that now famous patriotic slogan, "Your Country Needs You!" 


\section{The Railroads' Interest in Cut-Over Land De- velopment By D. C. Welty}

Commissioner of Agriculture, St. Louis, Iron Mountain and Southern Railway

Mr. Chairman:-I sincerely regret that the urgency of food production preparedness work and the rapidly progressing planting season prevent my remaining over another day and, as you have stated that I would be called upon during tomorrow's session, I ask the privilege of a word in behalf of one of the railroads which probably has as much cut-over land along its right-of-way as any one road in the South; and as secretary-treasurer of the Railway Development Association, which numbers among its members the development men of 90 per cent of the railroad mileage of the United States, I want to say in their behalf that we hope tomorrow's meeting will not close without some definite action on the part of the cut-over land owners and for the purpose of putting their vast holding to some productive use.

We have listened to many able addresses upon Southern agricultural possibilities and the agricultural problems of the cut-over land areas, but, gentlemen, if I understand the situation correctly, you are here to consider ways and means of marshaling the forces of the cut-over land owners, so that these owners can, in co-operation with the Department of Agriculture and other development agencies, put this knowledge into practice, get people happily located on the land and develop the country. I also believe that reforestation of the poorer lands justifies energetic consideration.

Every speaker has mentioned that he is an optimist as to Southern agricultural possibilities, both as to live stock and food production. It is true that there is no great accumulation of experience or data to eliminate every doubt, but it is quite evident that there are great possibilities. These possibilities have been ably covered by Mr. Piper, Mr. Rommell, Mr. Tracy, Dr. Dodson 
and others who have addressed us, and these gentlemen and their associates and assistants are available to put most efficient and profitable agricultural practices in effect. The agricultural departments already know and are practicing the things which will make for success, and this knowledge simply must be put in practice and much agricultural demonstration work done. The great problem lies with you men who own this land-most potent of possibilities but at present inactive, unused, covered with stumps and rapidly being covered with underbrush.

It is a question of financing and farsighted business administration and agricultural demonstration in which each with the help of existing agencies will have to solve his individual problems, and in which, collectively and as an association, you can most economically do much of mutual benefit, and for each other as individuals.

The railroads have for years seen the timber cut and shipped away leaving idle land, and just as the lumberman faces the end of his cutting and cessation of profitable activity unless his land is utilized, just so do many railroads face unprofitable operation unless

Railroads Anxious to Assist

Settler Must Be Liberally Financed these lands are exploited and reforested and developed by settlement by good and successful farmers. The development men of the railroads realize the importance of the situation and have given the subject much thought, as is evident by the fact that practically every railroad is well represented at this meeting. I see at least twelve railroad development men here who are vitally interested, and all ready to do their part when conditions justify energetic co-operation.

Some people think that there is at present no demand for cutover land, but that is not the case. Our Colonization Department has for months had unfilled demands for Southern cut-over land, and it would be a simple matter to stimulate the demand for such land were the railroads to get vigorously behind the movement; but, gentlemen, it will take more than exploitation and agricultural advice to successfully colonize the cut-over land area.

First, all must appreciate that the colonist is no longer a pioneer. The day of isolation, the squirrel hunter, the $\log$ cabin and rail fence are past. In this day of high-priced labor the settler will not undergo unnecessary hardship and the man with enough energy to move to a land of greater opportunity will not put up with slow, inefficient methods. Furthermore, the land-seller, community, 
county, state and nation can no longer afford to let men individually hack away on the old-fashioned land-clearing methods.

If a settler is an asset, it is a business investment to do such things as will get him started economically and efficiently and, as in this day and age, he won't come unless we do make conditions attractive, we have no alternative. The successful, present-day colonization methods tend strongly toward paternalism.

The colonization project must be liberally financed in order to enable selling with small initial payments and deferred payments extended over a long period of years with reasonable interest. The average immigrant has little money and what he has can be utilized best for the operation of his farming efforts rather than for large payments on the land. If the land is not good security for the deferred payments, especially with the colonist on it and improving it every day, the project is not worthy of consideration.

Again liberal financing is necessary because at least one-half and in all cases as much as possible of every farm unit that is put on the market should be cleared and ready for crop as soon as the colonist locates, and experience has demonstrated that if part of the farm is fenced by the buyer and a house and barn built, which he can pay for in his deferred payments, that is a great attraction. It also takes money to carry on the demonstration work which will guide his efforts most efficiently.

Schools, churches, stores and community centers all must be made available in one way or another. It all takes money and liberal financing is justified and of utmost importance.

Another fact that must be given due consideration is that the land-selling business has been developed by specialists into a business in itself. It might almost be termed a science, and the land owners individually and collectively will sooner or later appreciate that success depends upon either paying for considerable costly experience, if they handle the sales themselves, or must pay a fair price for the expert services and the tediously built-up organizations of those who have specialized upon land-selling.

The problems of organization and administration which confront each land owner individually are very great and no one of you can afford to study them out alone. Therefore, I hope this meeting will not close without some form of co-operative associaCo-operation Necessary to tion being inaugurated. 
At various times large land owners in our territory have discussed with me the possibility of developing their lands but it has always seemed to me that the fundamentals should be worked out co-operatively. Especially in the matter of land-clearing is much investigation necessary, and the expense of such an investigation, which would be equally valuable to all, should not be a burden to any one owner. Neither is it to be expected that any one state should do it for all the other states. If the Federal Department would do it, well and good, and an association could do well to bring all possible influence to bear in favor of such an investigation. However, if it is not done otherwise it would be an excellent activity for a co-operative organization of cut-over land owners.

Mr. Carl Livingston, of the Forest Products Laboratory in Wisconsin, and who will address you tomorrow, has some very valuable data and has done some great work. I went to Northern Wisconsin to see one of his demonstrations and I have followed his work closely. However, only yesterday in talking with me on the subject he remarked: "You will be surprised to see how slowly we are progressing in accumulating definite and dependable figures." $\mathrm{He}$ mentioned the many difficulties which have confronted him, a specialist in the work. I mention the matter to emphasize the fact that you should not as individuals try to solve the problem. It is a matter you should handle collectively. Just as the implement dealers have financed the work of farm implement specialists for some of the state agricultural college extension departments, just so could you land owners collectively, if you were organized, finance such investigations as you, after study of the situation, might find practical.

It is true that the agricultural industry is not universally and highly developed upon the cut-over land of the South and that many details will have to be worked out. However, every speaker has emphasized his optimism as to the possibilities, so.

Productivity of Cut-Over Lands

Already Demonstrated bearing in mind the many individual successes we know of on cut-over land, the great study both State and Federal authorities have made of the subject and their ability to cope with it when the need arises, let us concede that we can raise the various crops that have been mentioned. Let us concede that the live stock industry has great possibilities on cut-over land, and, in tomorrow's session, progress to the great questions of individual and collective organization and administration and agricultural demonstration which confront the cut-over land owner. 
I, personally, am engaged in general farming and commercial dairying on cut-over land. I believe the business has great possibilities, and, in view of my interest in the efforts of many of my friends along our line, who have cut-over lands now lying idle, in the interest of our railroad, which, unless you develop your land, will have an inactive railroad through your inactive land, also in behalf of the railroads generally and the many thousands of people desiring to locate on inexpensive land, I earnestly hope that these problems will be put to the front tomorrow and constructive efforts inaugurated. I regret that I cannot be with you.

(Applause.)

\section{What Florida Is Doing in Land Development \\ By James R. Murphy}

President of the Florida Land Development and Colonization Association

On behalf of the State of Florida, which unfortunately is very poorly represented, I must tell you, if you will bear with me for a minute or two, what we have done along the lines of organization. I have no inference to what has been said here by anyone, but it may in a measure help to solve the problem that confronts us all.

I have the honor of being, president of the land development and colonization interests of the State of Florida. We have in Florida, at the present time, 141 recognized land development concerns. Of that 141 , we have 20 of them in our organization We have an area of land in Florida of some 36 million acres. Of that 36 million acres we have less than 5 per cent of it under Operating cultivation. In our organization we have a representation of about 3 million acres of land, mostly cut-over land. Florida has been in the public press through the exploitations of some of her unfortunate land operators in the past to such an extent that it was almost impossible for a land operator to make a living in the state; and realizing that this existed throughout the 
Government Lends Valuable Assistance

country, we organized our land development and colonization organization, which had for its purpose the standardizing of the sale of land. The standardizing of the sale of land carried with it the demonstration of what the land was capable of producing, and so that organization had to establish demonstration farms. We searched in every part of the country for all available information, and the Departments of Agriculture have been untiring in their efforts to give us assistance. In fact, they have sent men down time and again to answer, perhaps, the same question; and we in Florida feel greatly indebted to them. They have taught us what grasses to grow; they have taught us the use and advantages of the dipping vat; and the lumbermen in Florida have taken steps for the raising of $\$ 50,000$ a year, spending $\$ 150,000$ over a period of three years, in a statewide campaign of tick eradication: and this was through the initiative of the Southern Settlement and Development organization, co-operating with the Department of the State and our largest land owners in the state. Mr. P. L. Sutherland, who represents one of the largest land owners in the state, has very ably helped the work; and, gentlemen. I have merely mentioned these facts so as to suggest to the various other states. represented here that in the solution of this great problem we realized, in Florida, that the most necessary step, first, was a state organization; and we are now ready to step into any organization that is formed for the betterment of the South.

J. Lewis Thompson: On behalf of the cut-aver land owners who called this meeting, I want to say-and I don't believe I am the most intelligent, but I believe I am about the average-I want to say to you men here today that the reason we are here is because we do not know. We are groping in the dark. Regardless of our railroad friends-they have always felt like whenever they wanted to say most anything they went to the lumbermen and got by with it. I think our railroad friend there was talking to me and to these others, because I am used to that kind of talk coming from the railroads.

I want to say, on behalf of the land owners, that we are in the dark, and in their behalf I want to say that we have had a most instructive and the best papers that I have ever heard in any meeting; and my only regret is that our entire organization could not have heard every paper read here, because I believe that before we can go down to the point of forming some kind of an organization permanently, what we must do is to tell you what 
we have got to do before we can get down to the organization period; and if our railroad men will stay with us until tomorrow-and if they are interested in this vast area of 76 million acres, if they are interested to the point that some of them have said-no other business could call them away; they can come in and if we can't form an organization we will certainly give them an opportunity to contribute. (Applause.) I am glad that speech has been made by a railroad man, because $I$ believe it is time that one railroad was waking up to the needs of the country and co-operating with us in the upbuilding of that country. I am glad, too, that he made that statement, because I believe we will get down to something before we leave.

\section{Demonstration Work on Cut-Over Lands By G. E. Nesom}

Superintendent of Livestock Extension Work in Louisiana for the United States Department of Agriculture

Mr. Chairman, Members of the Convention, Ladies and Gentlemen:-I promise you that I will not burden you with a lengthy speech this morning, and that I have nothing prepared especially for this occasion. I will, in the main, refer to things that have already been said. Those of you who have read "Peck's Bad Boy" in your early youth, probably remember the situation of the man who was good at figuring. After he had exhausted a good many other topics, he began to figure on the cost of fencing; and he found that to fence one acre of land it took a fence four acres long, and cost, after calculating the value of the Right and Wrong Ways of Figuring materials, and labor, a certain sum; that by quadrupling this area and making the fenced area four acres, it only took twice as much to fence the four acres as one acre, therefore reducing the cost by one-half; and proceeding in mathematical progression, grew to those enormous proportions by which he finally found that to fence an area stretching off to the Aurora Borealis, and eastward to the rising sun, and southward to the Gulf of Mexico. 
and westward to the Golden gate, the cost of fencing a single acre had been reduced so that a single toothpick would fence it and leave enough to build a church. (Laughter.)

Now, we might do a little figuring on the immensity of this cut-over land proposition. Our Chairman told us, on the opening morning here, that there were some 70 million acres of this land, and that it would produce, under certain conditions, from a thousand to two thousand dollars' worth of produce. This is almost enough to give every man, woman and child in the United States a farm of one acre; and if they were settled on those farms, and each of them produced the minimum of one thousand dollars, the vast sum of wealth represented by those farms would be 70 billion dollars; a sum, by the side of which the 7 billion dollars that our Congress is now being asked to appropriate to finance our army and our navy and the Allied Nations of the world; would be merely the usual 10 per cent waiter's tip.

But this kind of calculation savors of the millennium; it is the theoretical view. This convention has to do with not only an average, but with a very practical problem, and the question immediately involved now is that of developing and bringing into productive use as much of this land as possible on a purely practical farming basis.

A good many suggestions have been broached here and a good many ideas have been expressed, which in particular touch upon vital questions involved in the development of these lands. and one of those questions is the desirability of more exact knowledge of how this problem can best be accomplished, both from the standpoint of pure agriculture, and the still larger question that has been less hinted at-that of the business problems involved.

Now, I want to discuss those two phases just ior a few moments. It has been suggested that we need a lot of experiment stations-a lot of work to find out some of these fundamental

Demonstration Needed More Than Experimentation facts, these important problems, by actual experimental work. Using the term experiment or experimental research in its strictest sense, I am of the opinion that you do not need it anything like as badly as you need the simpler process of demonstration. If the term "experiment" be limited, as it should be, to original research, the development of new facts on original scientific lines, I am of the opinion that we know enough of the fun- 
damental facts surrounding these cut-over lands so that it would not be very desirable to waste any large amount of time or money in undertaking to do a great volume of original work, because a large part of that has been done, either in this section or in other sections comparable with it, which would obviate the necessity of that experimental work.

We had pointed out to us by a representative of the Bureau of Soils, for example, the fact that the soil survey, although it is by no means completed, has covered almost every type of land which is represented in the cut-over pine belt; and we know a great deal about those types of land; and the practical question here to determine is whether a given piece of land comes within a given classification of soil, and then apply the facts already learned regarding that type of soil to that particular piece of land. I do not believe, for that reason, in any extensive soil survey, but in the application of the knowledge we already have of that type. or that quality or class of soil, which can be applied by merely determining to what classification any particular locality belongs.

We also know what crops are particularly suited to these different soil types, and we have those crops growing in the South-practically all of them that are likely to be very useful to us in the cut-over district for some time to come. Once we know the classification of the soil we can readily find, in the existing publications or through inquiry at the special of fices controlling this work, a large part of the information as to what would be best to plant under given conditions. I know very well that there is a longing in the human mind always for that which is new and novel; and even in the face of the fact that a given crop has not been produced to any considerable extent, if it has succeeded in some remote country or in a small area of a limited section of the United States, many times a person is inclined to go after that rather than to take that which lies right at our doors, already tried and found to be absolutely reliable. It is so common; we see it so often, that we cease to think of its value, but look at it way in the beyond, like the ultimate end of this great fence. I believe in utilizing that which we have with us and which has already proven to be the correct thing, and let these other things come by a very slow process, and only adopt them on a large scale after they have proven their worth.

Now, to come down further to the particular application of these things-to the utilization of the cut-over pine lands-I 
Live Stock the Best General Means for Present Utilization
Different Sections Produce Different $R e$ sults

most heartily agree with those speakers who have said that these lands must necessarily be utilized for some time yet to come, in the main, for the production of live stock. I want also tc make a distinction between some of the statements, if made literally, regarding grazing and farming. I am of the opinion that the extensive use of cut-over lands for purely grazing or ranching purposes, uncombined with farming, is not the correct line for the utilization of these lands. I believe the system which will bring them into use most rapidly is a system of moderatesized farms, where there will be a system of crop production, and especially forage, and grain production, combined with stock raising; and, on the other hand, I do not think we are right in the reduction of the size of these farms to the small farm to which some speakers have referred; and more especially, in the remote sections, of their reduction to $10,15,20$ and 40 acre farms, where such intensive things as vegetable gardens, or even dairying. cannot be carried on successfully until the country is more developed. I think a happy medium between the two is what we should seek.

Now, as to the class of live stock production, I would always regard that as being a secondary question. The first question is: What will the lands produce and what can the farmer make them produce after he has them under his control, in addition to what they are already producing in their natural state? The confusion which seems to exist in the minds of a great many here as to the carrying capacity of these lands, for example, I think is so great that a few words on that may help to clarify the atmosphere. I believe one man said 1700 acres did not support 130 head; others have said that after putting as many as one animal to two or three acres they did not graze off the forage crops close enough to suit them; and we have had all kinds of variations, from some who said it takes 5 , or $7 \frac{1}{2}$, or 10 or 20 acres to carry a cow or cow and calf. The reason for this confusion, in my opinion, is the fact that one man is speaking of these lands under one condition and others under another. The same lands will vary very widely at different seasons, and from others under different conditions. We want to think of these lands in terms of carrying capacity of cattle-they have a rather high carrying capacity in proportion to the number of plants that grow and the fertility of the soil. They have a lesser carrying capacity in the early spring and late summer, and in the late fall 
and bulk of the winter their carrying capacity is so reduced that if a man speaks of them at that time, it is doubtful whether anyone could approximate the amount of land it would take to carry an animal. In fact, I have a letter from a lumber company in Southwestern Louisiana, in which they put the question to me, "How much of this land will it take to carry an animal the year round?" I answered them, in effect, that while it was satisfactory pasturage in the late spring and early summer, in the heart of the winter I did not believe their whole parish would carry a small herd satisfactorily, simply because there is nothing on that cut-over pine land after the frost has killed it. There are a few wire grasses: and the cattle having access to the winter-growing grass which we occasionally have, or to the cane swamps, which are very limited in extent, may do well. Ii confined strictly to the cut-over lands where it is open and the yellow pine growth has had full sway, there is so little on that land in the winter time on which cattle can subsist that the carrying capacity is reduced almost to zero.

Now, if this problem is to be looked at from the grazing standpoint, and does not involve forage production and the feeding of those herds in the winter time, when the pasturage is at its lowest ebb, we certainly cannot have a cattle industry which Forage Production can be at all satisfactory.

I need not discuss the question of the hog industry, because it has been considered by everybody in the South that the day of the range hog is past-that he would certainly have the poorest chance to graze the year round on these pine woods. It has produced a type of hog which did not exist before, and which is rapidly going out. Hog raising is on a better basis now, and we do not expect anybody to undertake range hog raising in the pine belt.

But there is another class of animals which has been discussed-and I do not wish to anticipate what anybody else will say of the sheep industry-but that should go hand in hand with the cattle industry, and on the same basis. In fact, I am not sure if many of these grasses are not better suited to sheep than cattle. The feeding problem would probably be less serious in winter, and especially so if Prof. Tracy's advice is taken as to providing plenty of velvet beans for winter grazing purposes.

I might discuss this question of forages at considerable length, but it has already been discussed by representatives here, 
Business

Problems

Involved
Tick Eradication Basis of Cattle Industry dealing especially with the South, and I shall not go into it any further.

Now, as to the business questions involved. Those of you who own this land, have no doubt spent many worried days and nights trying to devise a scheme by which you could sell those lands. The average owner of cut-over pine lands in large areas wants to sell. That is the uppermost thought in his mind. I do not think that should be the uppermost thought. I think the first consideration, under existing conditions and viewed from the business standpoint, is that every owner should desire to improve those lands and make them more valuable than they are, so that he can get more nearly what they are really worth for agricultural purposes. We have been told here that pioneering is not a trait of the modern farmer. I know this is the case with the American people, and especially when they attempt to work as corporations or to use large aggregations of capital. I know that the very small farmer, who has no means and nothing to work with but his own hands, is handicapped in developing his farm, because he has neither the means himself nor possesses the credit to obtain them; and the question of what the landowner should do to fit those lands for farming, all the way between those two extremes, is a problem which has to be thought out from a business standpoint. There are certain things, however, which we may conceive as already demonstrated and accepted facts. In the first place, I want to mention the fact that these lands belong to the people who hold title to them, and they have a perfect right to use them for their own purposes, and they have a perfect right to exclude people who have cattle, for example, but have no land and raise their live stock by grazing them on the other man's land; and that right must not be denied to the owners of these lands if they choose to fence them; and there comes in an important question which I think is going to be at the basis of developing these lands for live stock purposes. In many sections of the cut-over pine belt, tick eradication has made splendid progress; in others, we are going to have a great deal of trouble to complete that process. There are conditions under which there is going to be great difficulty in getting that work supported. I think every owner of cut-over land should insist that his land be freed from ticks, and if he cannot get the cooperation of the other people of his community to free that whole parish from ticks, he can at least reserve to himself the 
right to fence up his own lands and free that from ticks; and if that was done in some parishes in this state I want to say that there would be mighty few grazing lands left. Tick eradication is going to be the basis of the modern cattle industry on these cut-over pine lands, whether it is done, or is in process, or is yet to be undertaken. It must be finished before any extensive catthe business can be brought about; because we must introduce better blood for those herds, or entirely new herds, as one of our speakers explained yesterday; and I maintain that there are plenty of men in this cut-over belt who are able to establish those pure bred herds; we know that, but unfortunately, like the calculation on the cost of fencing an acre, the average man is not able to do that, and you must keep within practical bounds and not go beyond your financial ability in trying to do something you are not financially able to do, and of which you would not make a success. The average herd must be improved by breeding, in order to bring the cattle up to a better standard. We must not subject them to the nuisance of these ticks, which will ruin many of them and result in losses we can ill afford to sustain.

The fencing of these lands, in my opinion, is one of the essentials for their best development. The next problem and the biggest one of them all, is the removal of the stumps from that portion of the soil to be cultivated for the production of the winter feeds; at least, it certainly is desirable that this process be pushed forward until all the farm shall ultimately be freed from stumps. These stumps are such a serious obstruction to modern farming, such a detriment to every process we undertake, that their total elimination from cultivated areas must be a prime consideration.

Now, I do not think we are all agreed on how this stump removal shall proceed. There have been a great many processes tried; a great deal of data has been accumulated, and especially by the people operating these demonstration or experiment farms on properties of the different companies; but that information has not been consolidated and reduced to a system so that we can draw a definite conclusion; and, as someone has hinted, I doubt if we will ever get much of that information. We do know, however, that the yellow pine stump is one of the hardest propositions that any stump puller has ever tackled. There is nothing in the line of stumps near so difficult. We do know that at

Fencing and Stump Removal

Best LandClearing Methods Still Uncertain 
least in a few instances every success has attended the burning of these stumps by that simple process of digging a post hole, boring an augur hole down through the stump and letting it dry out, and then building a fire in that post hole so that this augur hole will act as a flue and will contain so much rosin that it will readily burn out in most cases.

Now, the men who demonstrated that the average of these lands could be cleared at a price not to exceed $\$ 10$ per acre, by contract, has attracted a wonderful lot of notice which is of value from a business standpoint in the handling of this problem. If I were a farm operator, that information would be very valuable to me; but we have not yet gotten to the point where we can get hold of this information at a given time. We are given sorne of it merely in fragments.

Now I come to another point, which I hesitate to broach and which I do on my personal responsibility rather than as an official of the United States Department of Agriculture. It has been suggested that some form of organization be perfected here

Land Owners Should Exchange Information by which all the information thus developed can be consolidated, and that definite arrangements be made by which additional information will be gotten and made available for all parties interested in this great problem. Now, if we look to see what has been done, we find the Federal Government and the several States are only touching this problem very lightly. Some of them have several experiment stations and demonstration farms and have developed certain information which can be had for those particular localities. There are probably several hundred lumber companies which maintain demonstration farms and experiment stations, or whatever you choose to call them. I believe most of them are small demonstration farms where they are getting a lot of valuable information; but they put that information in their files in their offices and use it for their own purposes, and no one else profits by it; and more especially do we not get that information which is of an adverse nature, and which sometimes is worth more to us than the positive facts developed. When you get a warning what not to do, you are just as well off as when you get information as to what you should do; because in the one case you positively have a loss, and in the other you merely have an opportunity to make a gain. If the interests of these cut-over pine land owners could be consolidated in such manner that all the information, both pro and 
con, developed on all these demonstration farms could be consolidated and then be distributed to everybody concerned, it would make a fine lot of information well developed; and this is one of the things I would suggest as being desirable. Now, it is probable that if this series of farms were looked over, we would find that they were not ideally located so as to cover all types of the cut-over district. We had reference yesterday to the Orangeburg Sand and others of the Greenville clay type, all of which represent more or less distinct types of country. Are these farms so located that we could get data from all classes of them, in case they were all consolidated, and the data were published in some bulletin or other consolidated form? In my opinion, we would have to go a little further and have a central clearing house, through which it would be more certain that all types would be represented. Some system might be arranged for buying some of the present farms which adequately represent the work on different types of land.

I would rather call these demonstration farms than experiment stations. I believe they ought to be under a consolidated management. I believe their management should have the best agricultural talent that can be had. I know some farmers trying to demonstrate facts regarding cut-over pine lands today, where their work has been to a large extent vitiated, due to the fact that their failure has been brought about by men from other sec. tions, who may have been an eminent success, but who are not competent, with all due respect to their success otherwise, to handle the question of agriculture in this section with which they are probably not familiar. The new system of demonstration farms of this kind should be under the control of men who know agriculture primarily.

Now, I want to go one step further and suggest a practical means by which this can be done, and I will illustrate it by saying that a few years ago, when the Hawaiian Islands were attempting to develop the sugar business along modern lines, they sought the world over for some information. The Louisiana State University at that time had about the only sugar school and experiment station that was doing very much, and I violate no confidence when I say that Louisiana did not look with a great deal of favor on seeing the Hawaiian Islands go into the sugar field, and they didn't go out of their way to give the Hawaiian planters any particular information. They soon re-

Suggests One General Management 
solved that if they couldn't get any information regarding their own industry in their own Islands, they must get it at their own expense and in their own way; and after conferring and consulting for quite a while, they decided they would establish it on a thoroughly business principle, which would hold good as long as they chose to perpetuate it, and which would give certair returns; and the system agreed upon was that every manufacturer of sugar in the Hawaiian Islands, who chose to become a member of the Hawaiian Sugar Planters' Association, should ship his sugar or report his sugar through the Association, in Honolulu; and that he should pay into the treasury of this Association the sum of 25 cents on every ton of sugar which he turned out from his factory. This sum of money was consolidated and used by their agricultural board for the establishment, maintenance and operation of the Experiment Station,

Early Difficulties of $\mathrm{Ha}$ waiian Sugar Industry Solved by Cooperative Association

One Cent an Acre Means $\$ 750,000$ which was to send out information regarding the sugar industry in the Hawaiian Islands. This fund, in a few years, had reached fifty and then ninety thousand dollars, and now it is a hundred thousand dollars. They have one of the best sugar experiment stations in the world and they are doing splendid work. In later years they have correlated it, more or less, with the Government work, and thus, to some extent, the information which they are developing there is available to other people: but, in the main, the facts developed have gone, in published form, and in letters, circulars and otherwise to the members of this Association; and to this day, whenever they have anything which they think might be used by the other fellow to their disadvantage, they give it only to their members.

Now, if these gentlemen who own these lands, desire to institute a system which will work for the common good of the cut-over pine lands, and to use this same idea-which is entirely practicable-the raising of the necessary funds by a very small assessment against the lands, they can do it. You can soon see what 1 cent an acre would mean on this 75 million acres- $\$ 750$. 000 . One-tenth of a cent an acre would give you $\$ 75,000$, if all the land were included. I don't know how much you might want to raise, but if you could raise any such sums as that, some work could be developed which would give you much of the information you seek, and which is so badly needed; at least, the consolidation of existing facts and their application to your particular problems. 
Before closing, I will say, in a brief way, that I have been watching these cut-over lands very closely during the past three years, and in my opinion they are a splendid agricultural resource, with wonderful possibilities. I do not mean to say they will compare with our richer lands in Louisiana or Mississippi, but I do say they are valuable agricultural lands that are quite capable of sustaining a large population and capable of producing an immense amount of wealth by a production which will compare very favorably with the average lands of the South; and I trust that the examples already set by many concerns and individuals in demonstrating their possibilities, and bringing them into practical use, especially at this stage of the great crisis, will not be delayed longer than is absolutely necessary, and that you will bend your efforts towards making them contribute their part towards the support, not only of the Government in times of peace, but more particularly at this eminent crisis. I thank you. (Applause.)

S. F. Morse: I just want to drive home a very important point made by Dr. Nesom, by a concrete instance. The point I mean was, that there was, to a large degree, enough practical experience and demonstration to enable us to determine what can be done and to formulate a plan for the development of these lands.

The experience which I wish to state is this: About three years ago, in the State of Arizona, when they started the agricultural extension work, we found ourselves covering a large area of land about which we knew nothing. At the outset, as I just stated, we found we had no experimental data for the development of these large areas of land. What were we to do? These lands had many settlers on them and they were crying out for information. We didn't bother with the experiment station; we cut loose and got busy and found out what they were doing in other states and in other parts of the country where conditions were similar. We investigated the live stock business and got different experiences, and then we worked with the farmers and gave them this experience. The result is that today, where we were previously shipping in sack lots, we are now shipping in carload lots; and that has only been within a period of three years.

That was done, as Dr. Nesom has suggested, by taking the different conditions in other parts of the country, and of the dif- 
ferent states and the Federal Government, and giving that information to the farmer in practical form. The point was: That information had to be passed through a central source, and translated into terms of practical application to the local conditions, and that is what you people have today. I simply want to give you confidence in this proposition.

Dr. C. V. Piper: There is a very important distinction between experimentation and demonstration. You cannot demonstrate a thing until you know it. Do you get that? Now, I think my friend's ideas are not very far off, but I don't like his confusing two words, experimentation and demonstration. If I understood the speakers right yesterday, they think that with

The Distinction Between Experimentation and Demonstration the information we already possess live stock farming on an extensive scale on these cut-over lands can be made successful. They had in mind the establishment, under practical conditions and with a minimum expense, a place where all these pieces of knowledge could be put together and then cited. I submit to you that this is an experiement station, not a place of demonstration. If we had the knowledge we could go ahead and do it. I call that demonstration. Then there would be no need of the meeting here today. The experiment station that I had in mind and that Dr. Nesom had in mind are pretty nearly one and the same thing; but until we have the knowledge, you cannot call it a demonstration. It is a very important distinction; and I think we will get our minds confused if we confuse experimentation and demonstration. 


\section{How Louisiana Is Solving the Reforestation Problem}

\section{$B y$ M. L. Alexander \\ Commissioner Department of Conservation, State of Louisiana}

How Louisiana is solving the reforestation problem by the actual growing of trees was told the Cut-Over Land Conference of the South by Hon. M. L. Alexander, Commissioner, Department of Conservation, State of Louisiana.

"On the State Forest Reserve at Urania, La., a forest is being made again," said Mr. Alexander. "Not a wild tanglewood of shrubs and seedlings, but of real trees. Trees that will make lumber of a superior grade are growing on fields that during the Civil WVar period grew cotton for blockade running to England. Here we have trees of every age that were not of the virgin forests, but sprang from them, and in which the hand of man has but assisted nature."

The speaker declared that one of the first results of the experiments was to discover that, not forest fires, as had at first been supposed, but the razorback hog, was responsible for the fact that the prized long-leaf pine had for many years failed to Razor-Back Hog a Menace reforest itself.

"Mr. Hardtner's investigations," he continued, "proved that the kernel of the long-leaf seed is oily, rich in nutritious matter, and palatable to the hog. When the seedlings are one year old the root and short stem are spongy, sweet and tender, and it is amazing how many seeds, seedlings and saplings a razorback can finish up in a half a day's work, one hog averaging five seedlings a minute. The seed of the short-leaf and loblolly are very small, and neither these nor the seedlings are relished by the hogs.

"On the preserve we now have 2,500 acres inclosed with a hog-proof wire fence, 2,500 acres under an ordinary fence and 2,500 unfenced. In the hog-proofed area the long-leaf pine seedlings are numerous, in the regularly fenced area there are a very 


\section{Longleaf}

Seedlings Survive Fire

few, and in the unfenced tract there is not one-a complete destruction of the seed crop.

"Experiments have been made of burning over tracts $h, y$ setting fire to the sedge grass that grows very heavily on the preserve. It makes a very hot fire, but from actual count from 50 to 90 per cent of the long-leaf seedlings survived the conflagration, and in a few days the buds put forth new green straw, and they are healthy and vigorous today. The fire would burn off the seedlings' straw close to the ground, but the bud is evidently green enough to survive the scorching, and a two or three-year-old seedling will survive the fire much better than the year-old ones.

"Mr. Hardtner and I are convinced that reforestation of long-leaf is impossible where the hog roams at large rooting up the seedlings; we are convinced that fire does not do as much damage as was thought, but notwithstanding all this we are opposed to fire at any time and do not advocate its use. If forest areas are to be burned over to remove dried grasses, let it be done in the proper season-the winter following a rain that has soaked the ground. Very little damage will be done then.

"We have long advocated the leaving of one or more seed trees to an acre when the lumberman fells the timber for his sawmills. This is truly a method of conservation, and if adhered to by lumbermen will soon have the cut-over area reforested with seedlings. If these seedlings are properly protected and the young trees thinned as they grow, the forest that will take the place of the original will yield even richer returns in from fifty to sixty years.

"If this method of reforestation is carried out, in forty years one may expect to have a good stand of timber on forest lands, hardly ready for the millman's saw, but good thriving trees ready for lumbering during the next ten to twenty years thereafter.

"At Urania it is being demonstrated that it is just as easy to grow 50,000 feet of timber to the acre in sixty years by assisting nature as it is for unaided nature to produce 5,000 feet Profits in Reforestation in the same period. And thinning does not mean endless expense for the tree farmer, for we have demonstrated on the State Forest Reserve, using a 21-acre plot of short-leaf and loblolly, that proper thinning gave 180 cords of wood, 555 tram ties, and 200 posts worth $\$ 258.75$ at a laboring cost of $\$ 205.00$, a profit of 
$\$ 53.75$, or $\$ 2.55$ an acre. This sort of profit is sufficient to pay all taxes and incidental expenses.

"Accurate measurement has been taken of the trees in the different lots, photographs taken, and in some cases every tree numbered and recorded so that comparative figures will give absosolute proof of the growth from season to season. Our method is to let nature take its course in the matter of seeding for reforestation. This is very satisfactory and there is no expense of tree planting by hand to deduct from the profits when the lumber is sold. With long-leaf pine seed crops are infrequent and several years elapse between the crops. This is not so with short-leaf and loblolly; therefore, reforestation on denuded areas with these species is not difficult if seed trees have been left standing, as a crop can be counted on almost every season. At Urania our records show that there was no crop of long-leaf mast in 1912, a hundred per cent crop in 1913, a 5 per cent crop in 1914-15, and a 50 per cent crop in 1916. In virgin forests of long-leaf, the seed seasons are sometimes five or ten years apart, but vigorous young pines in denuded areas bear seed more frequently and abundantly.

"A record made on an acre in one of the experimental plots shows 251 trees ranging three inches and under to 22 inches D. B. H. will yield at the present time 13,544 feet. By adding four inches to the growth in 20 years it will yield 42,388 feet. Stumpage now sells at $\$ 5$ per thousand feet, but twenty years from now we will be safe in presuming that it will sell for $\$ 10$ a thousand, or $\$ 423.88$. If converted into lumber and delivered to Growing $a$ Forest at \$2 a Thousand Feet Northern markets it will be worth at least $\$ 1,200$. Mr. Hardtner's recapitulation is that the cost of growing timber will be around $\$ 2$ a thousand feet.

"Thus have we met the reforestation problem in Louisiana and our theories have been sound, as our results indicate. We can show you that timber can be grown on timber land at a profit. We can demonstrate that lumber that has long been supposed not to perpetuate itself does so if enemies are removed. We have a healthy regard for the dread forest fire, but we have also learned that it is not so bad as we have been thinking it.

"We also-believe that the owner of cut-over land will find it to his advantage to go timber farming, and that all cut-over land does not necessarily have to be plowed under for crops until 
there is need for this land, and that the interim can be profitably spent in working out reforestation."

Mr. Alexander declared that before reforestation can be successfully carried out, existing methods of taxation on timber lands would have to be radically reformed.

\section{Some Problems of Colonizing Cut-Over Lands$$
\text { By H. A. Weare }
$$$$
\text { of Mobile, Ala. }
$$

Distillation

Plants Make Stumping Profitable

The Question of Marketing

It was not my intention to take any active part in this program, here, but I would like to make a few remarks covering an experience of sixteen years in which $I$ have been handling and studying cut-over lands in the Gulf Coast territory. My specialty is handling timber lands, and I believe it is always necessary to handle cut-over lands as well. What really brought me to my feet is the remark Mr. Alexander just made in reference to the distillation plants.

In making a study of these cut-over lands and how to handle them, I have concluded that these distillation plants should really be put in with every proposition. What does it mean? It means that the man clearing up his own land is really helped, as he gets a good market for his stumps.

Another question not dwelt upon very much is the question of marketing your products. In looking around and observing the different farmers in the Gulf Coast territory I have had every farmer tell me, "We have no difficulty in producing crops, but we do have a hard time in finding a sale for them." That is something that must be taken up and considered in connection with settling your land. You can bring people down here from the North and produce the stuff, but you must give them an outlet to sell it. When I first came South and started buying some of these cut-over lands, myt friends told me I was very foolish. That was sixteen years ago. They thought it was absolutely no good. To illustrate to you what some men thought 
of it, I know one man who sold 50,000 acres and stated to me later, "I slipped in 10,000 acres of cut-over land at the same price and they never noticed it."

In determining why I thought these lands would have a value, in going around $I$ would find that one farmer was raising velvet beans and other fine crops; I would find another man who had cow peas; another man produced a big crop of Irish potatoes; and in that way I found, scattered all around, where they were producing practically all the different things we have heard mentioned here today. I have seen that for years. It has all been demonstrated. I really believe that is the way you will get your land settled. It is very difficult to go to Iowa and bring those good farmers down here and settle them in the wilderness. You will find that most localities in this country require three sets of people, before the good substantial farmer arrives. Another thing is that we are all getting good roads and automobiles, and though you are eight or ten miles out in the country you can still keep in touch with things.

In selling these large tracts I have noticed one great difficulty has been that so many of the colonizers do not care anything about what becomes of the men after they sell them a tract. That is one of the greatest difficulties. I have sold a good many large tracts, and I have observed that in 60 or 70 per cent of the cases it is just that way. They don't seem to for the Colonist care where the man lands after he gets there. That is all wrong. You must look after the man and see that he is taken care of. 


\section{The Dairy Industry of the South}

\section{By C. W. Radway}

The South's

Advantages for Dairying
Some Essentials to Successful Dairying

\section{Dairy Specialist, Bureau of Animal Industry, United States Department of Agriculture}

There are several reasons why the dairy industry, should be prosperous in the South. The South is well adapted, I believe, to successful dairying. One of the reasons for this is the climate. The barns or buildings that are needed are less expensive than those needed in the North; and the climate is such that we can depend upon pasture for eight months out of the year. I might state there that some people are trying to depend upon tivelve months of the year, and those people are the ones making a failure.

We have been doing some record work and testing and weighing milk all over the state, and for the past four months we have not been able to find any piney woods cows producing much butter fat. Another thing is that forage crops can be very easily raised here in the South. But, however, with all these advantages, there are some essentials to the dairy business that must not be overlooked. One of these essentials for success is efficient dairy cows. Second, is sufficient home grown feed; and the man that comes down here with the intention of going into the dairy business must see to it that he is locating in a place where he can grow forage for his cattle. It will not do to start a dairy farm where you can grow nothing but strawberries or rice. If you intend to start the dairy business on such land you are going to fail. The third essential, to go with these other two-the cow and the feed-is the man. A man has to understand how to take care of a cow, how to feed that cow, and how to make a good product, whether he is selling whole milk, cream or making butter; and in connection with this milk problem, or with the dairy products, one of the main things is quality. Those people in Louisiana making good butter have no trouble at all in marketing it. Those people making a poor product find that product is not wanted. We have several instances here in Louisiana-one man at New Iberia cannot supply the demand. 
He could sell three times as much butter as he is making at the present time. The Ruston Creamery, at Ruston, Louisiana, cannot fill half the orders they have at the present time, and the same is true of the New Iberia Creamery.

There are several advantages to be derived from dairying. The first advantage, which should appeal very strongly to every Southern farmer, is that the dairy, well conducted, improves the soil. A dairyman in North Louisiana, on cut-over lands, who started in about six years ago on land that was producing less than one-third a bale of cotton to the acre. He saved the fertilizer from that dairy and put it back on the land, and today he is producing as much cotton on half the ground he did six years ago. In other words, in six years' time, with the intelligent use of the dairy and his by-products, he has doubled the productive capacity of that farm. Another thing is that it furnishes a market for crops, as some of the crops that cannot be marketed because of the small quantity and the distance to market. If a man has only a few tons of pea vine hay or soy bean hay, and cannot get it to the market, the best market is the dairy cow. Again, he may have some forage crops that are not in marketable condition, some that are poor in quality. That can be used for feeding and put right back on the soil. One instance of this: At New Iberia a man used cane tops for silage-not that I would advocate cane tops for silage, but it helps out in his feeding, and is one of the by-products of the cane.

A man that makes a good quality of product, butter or cream or whole milk, is sure of a market; but the quality must be good. I might state at this time that in any whole milk industry, a great improvement can be made by more winter dairying. In that way a more uniform supply can be furnished in the cities. Last November and December some of the places along the Illinois Central were-shipping only about half what they are at the present time, which, you see, is not the best way of doing.

Some of the farmers claim they are not making money in the dairy business. There are some reasons for that. First, the cost of production is too high; and there are many cows in this state that are not paying for the feed they eat. The second reason is the lack of system in feeding. If you investigate some Reasons for Dairying Failof the good farms, you will find that every cow in that dairy is getting the same amount of feed, regardless of the amount of milk she produces. Third, you will find there is no economy

The Cow as a Soil Improver

Dairy Products Command Ready Market 
Results from

Good and

Poor Cows

An Example of Successful Dairy Operation

in the labor. Much of the work may be saved; much of the work may be done to better advantage by doing things a little different, and possibly locating a little differently. Fourth, is poor equipment. Many of you are not sufficiently equipped to handle the milk and get it to market in good condition. Fifth, is the cattle tick, which will be spoken of later; and we trust that the cattle tick will be eradicated in a very short time. Also, one of the most vital things is the lack of home grown feed. Among the farmers we have visited within the past three or four months, those people having no home grown feed were contemplating selling their dairies because they could not afford to buy feed from the market.

Now, these apparent disadvantages are being overcome. One of the best ways of farming here is by getting better cows. It is essential that we have this. We have a farmer at New Iberia who just bought a few cows. One of them had a year's record of 600 pounds of butter fat. When you compare that with a cow producing 100 to 150 pounds, you may see the difference. Another way is by weeding out the poor cows by herd record work. One of the dairies in the northern part of the state had 35 cows. It started the record work there a little over a year ago, and three or four months ago we began selling cows that were proving they were not paying any profit. After eight cows were sold, and by better feeding of the remainder, we sold as much milk as we had from the original 35. By this record work better methods are being introduced; better care is being taken of the milk; better feeding is resulting; better care of the cows; and it gives the farmers a better chance to plant for home grown feed. This record work along the dairy line, I believe, is the most important part of the work that we do. I might say that the Live Stock Extension Service is supervising the record work of some of the dairies in this state, and some interesting results are found.

Two years ago a visit was made to a dairyman. After explaining the advantages of keeping records of each individual cow he decided to keep a complete record of his herd. Each cow's milk was weighed each night and morning and a butterfat test was made once a month. Each cow was charged with the feed she had eaten. At the end of the year four cows were sold that were making no profit at all. The second year cane tops were used with corn for silage. Four cows were added to the 
dairy to make 50 (the original number). Last year, by the use of cane tops and home grown feeds, $\$ 300$ was saved on feed and more butter fat was produced than the year before from the same number of cows. When the record began at that dairy the average butter fat production per cow per year was about 170 lbs. At present the average is about $240 \mathrm{lbs}$., and at the end of this year all cows not making $250 \mathrm{lbs}$. of butter fat will be sold. By systematic feeding, business methods, and home grown feeds, this man has saved $\$ 300$ per year on feed; at the same time has increased the butter fat production per cow $70 \mathrm{lbs}$. per year. This is an increase of about $\$ 30$ per cow or on 50 cows this record work has been worth $\$ 1,500$ to this man. This is not the only improvement he has made; he has increased the fertility of his soil until other farmers around him are commenting on the excellent crops on his farm.

This work of record keeping is being carried on with several other farmers with excellent results. One dairyman at Monroe, La., last week found that three of his cows were making more profit than the other nine. It is essential, with the high price of feed, that the dairyman feed only cows that are capable of turning that feed into butterfat and leave a profit. With the advancing prices of dairy feeds it is fast becoming necessary for the dairy farmer to "weed out" all unprofitable cows or else he will find the dairy on the wrong side of the ledger. Many dairymen are planning on more home grown feed than they have ever raised before. They are very wise to do this under the present outlook. Some of the dairymen who have been raising their own feed are setting the pace in the dairy business for the rest of the farmers. One man on the cut-over lands has been in the dairy business for about five years and each year he has increased the amount of home grown feed. Last year he built a silo and raised corn for 50 tons of silage; in addition he has sufficient soy beans and pea-vine hay to feed all the stock through the year. All the grain he had to buy was a little cottonseed meal to help balance up the ration. This dairyman is one of the most prosperous men in that portion of the state. This year he is planning on building a new house with the savings from the cream checks (and he saved a little each month because he did not have to swop his cream checks for feed). This man used his land to help feed his dairy and he used his dairy to help feed his land. The two are working well together,

Three Cows Worth More Than Nine 
and the crop production is getting bigger each year. He is well pleased with the results from the dairy and knows that the dairy and the land must work together. When we consider that this man started with little or no capital, on a poor farm, with no buildings worth speaking of, we must realize that he has been following a safe method. His method or prime object has been to build up the land by the use of the dairy fertilizer, to grow all the roughage for the dairy, and as much of the grain as possible; he has also practised rotation of crops to good advantage. The results of this system is being noticed by other farmers in that locality. Several are beginning to follow the same method. It has been clearly shown that feed crops can be grown on the hilly lands and on the cut-over lands and must be grown if the farmer ever expects to make a success. He must also realize that the land cannot do its best without live stock on it; that the

To Succeed,

Dairyman

Must Raise His Own Feed dairy in particular will build up the land faster than can be done by any other method; also he must realize that in keeping the dairy he must grow his own feed, or at least all the roughage and as much of the grain feeds as possible.

Last year we spent a good deal of time on the worn ont cotton lands of North Louisiana urging the farmers to plant velvet beans. We had some difficulty to get them to try this plan. Several tried velvet beans, however, and this year the difficulty is to get enough seed. Some of the dairymen who did not raise their own feed are going out of the business; those who raised their feed are making good. The difference between the dairyman who raises his own feed and the one who buys his feed is the difference between success and failure. As the prices of feed stuffs advance, this difference becomes greater. It is imperative that we urge in every possible way the dairyman to grow his own feed. Our whole campaign at present is "home grown feed and better cows." 


\section{Some Suggestions for Dairy- ing on Cut-Over Lands By N. P. Hull}

President of the National Dairy Union

As your chairman says, I have come a long way-came down from Lansing, Michigan. I have been interested in dairying all my life; started in to milk cows when I was knee high to a June bug and have followed it all my life. I have come South to tell you about the dairy business and how it ought to be applied in the South. I will tell you that story in ten minutes. I can talk pretty quickly, too. Perhaps you want to know why: Up in Michigan we manufacture 72 per cent of all the automobiles made in the United States. WVe don't use them all there but we test them all there. These automobiles run up and down and all around, and the people there are divided into two classes-the quick and the dead. (Laughter.)

I am not going to say all I had in mind to say to you. I have heard a great deal about the wonderful fertility of the soil and the wonderful opportunities in the Southland. I have traveled over this Southland considerably, as well as over the other lands-practically all the other states. In my work connected with the National Dairy Union, and as President of the American Dairy Farmers' Association, and connected with several other associations, I have lectured on dairying from one ocean to the other, and for two years to the Canadian Government. So I feel I have at least had an opportunity to know something about dairying. I have also had an opportunity to know something about conditions in the different sections of the United States.

I might repeat again-I have heard a great deal about the opportunities of the Southland. I am running a dairy in Michigan, and a great many other people are. We are buying carload after carload of cottonseed meal grown upon the land of the South. We pay $\$ 1.00$ for your cottonseed meal for feeding to our dairy cows, and from those dairy cows we send the butter back to New Orleans and sell it, and we sell you two dollars' worth 
Muking a Dollar Bring Two in Return

\section{Dairying} Makes HighPriced Rich Lands

Three Kinds of Cows of butter for every dollar's worth of cottonseed meal we buy from you. Your land grows that cottonseed meal; it takes the fertility from your lands; you send it to us, and we feed it to our dairy cows, and sell it back to you for $\$ 2.00$. That may be good business for you in the South, but I don't see how it can be. We are satisfied if you are. But you ought not to be satisfied, gentlemen. It means that the man who tills the land here in the South should not blight the land he tills, and too many of you fellows here in the South have been blighting your land until it is not as good and attractive land as it was a few years ago. You ask me how I know? I don't know just about this particular vicinity, but I do know about several other vicinities, and I dare say it is true in this part of the country.

Now the solution. In my judgment-and I know it is true in every other section-you go to the richest and highest price land in Iowa, Wisconsin and Michigan, and you will find that the industry that made that high price and made the farmers that handle that land so prosperous, was dairying. You go into the cut-over land of Michigan and find a man who is improving the fertility of those farms, to make them productive, and you will find he is improving them by the industry of dairying. It is true on high priced and on low priced land. Why? Because the cow will take the product of your farm and convert it into more dollars, carrying a larger percentage of profit than any other animal that walks on four legs. She has done it in the past and will do it in the future.

As one of the speakers said, there are certain essentials that must be observed on the farm. First, you must have a good cow. There are in the State of Louisiana, as well as in every state, three kinds of cows. One kind of cow takes her feed and digests it, and under the law of her nature she converts that into beef. That is a beef cow. It doesn't make any difference whether she is Hereford, or Shorthorn or Angus. If she converts that into flesh she is a beef cow. Another kind takes her feed and assimilates it, and because of the law of her nature she converts that into milk. That is a dairy cow; and it doesn't make any difference what breed or color she is; if by the law of her nature she converts that into milk, she is a dairy cow. Another kind of cow takes her feed, and God only knows what she does with it-she neither makes meat nor milk with it. (Applause.) 
I want to say to you gentlemen just remember that little message from the men of the North-too many of you fellows are spending your lives growing that cow that is in the third class. She should be got rid of. You are keeping too many cows that came too near to being born steers. (Laughter.)

I promised I wouldn't talk over ten minutes; I have two minutes more. As I said, I am President of the National Dairy Union. It was organized especially to protect the good cow and the product of that cow from vicious and unfair competition of the socalled substitute, oleomargarine. I just want to drop this little word to you before I leave. In our work in Washington we found that the Congressmen and Senators from the South are usually against us and with the oleomargarine fellows. I just want to say this to you: I want to ask why your representatives are against the dairy cow and honest dairy products; why your men say that the man who manufactures oleomargarine is just as good and has just as good a right as we have. Let me ask you why it is that a man colors butter? To make it look Oleomargarine a Menace to Dairying exactly like what it is. Why does a man color oleomargarine? To make it look like what it is not, and so that he may sell it at the price of butter, which it is not. You are getting swindled both ways. I want you to think about that, and stand with us of the North to protect the cow. Probably you have several million dollars that you want to buy oleomargarine with. Instead of doing that, go into the dairy business; feed out your own cottonseed meal, and your velvet bean and other products that you grow; return the fertilizer to your farm, which will enable you to have better farms as the years go by. You will find that that good old cow will do more for you than any other animal that ever walked on four legs. I thank you. (Applause.) 


\section{Tick Eradication}

\section{By Dr. E. I. Smith}

Inspector in Charge Bureau of Animal Industry, United States Department of Agriculture, Baton Rouge, La.

In taking up the subject of "Tick Eradication," I will briefly outline the history in the State. In 1906 the State of Louisiana began its first work in tick eradication. At that time there were two Parishes which started work along such lines; that is, Lincoln and Claiborne, and it is believed that they commenced operations largely because the State and Government urged them for the purpose of seeing what could be done in Louisiana; and if the results were satisfactory it might have a tendency to encourage the other Parishes to do likewise. After a few months Lincoln

Early Work Parish decided to withdraw her co-operation on account of so in Tick Erad- much opposition developing in her borders; but Claiborne Parish ication continued until 1912, when they were released from quarantine. For some reason or other Claiborne Parish did not furnish the proper co-operation, and the State and Bureau officials bore most of the expenses, and, as a result, when the Parish was released they failed to appreciate the advantage of taking care of the local infestation left in the Parish and enforcing the law when necessary. In this connection, I regret to state that they were placed back in quarantine the first day of March, 1917, with the same status relative to the cattle tick as any quarantined Parish in the State.

This vividly illustrates one prominent point: Notably, any

Popular

Approval

Necessary Parish or County in any State which starts tick eradication without the co-operation of the people is an absolute failure. In such cases more harm will result than good, because people believe that the officials higher up are endeavoring to make them do something which is not for their interest.

This year we had a few Parishes that were very anxious to commence systematic tick eradication, and the Police Jury called us into conference, asking our advice, and at the same time stating how many vats they had, and in what position they were 
financially. After taking into consideration their financial condition, and the small number of vats in operation, we plainly said to them, "Gentlemen, you are not ready to commence active work in tick eradication; you have not the sufficient number of dipping vats, and your financial condition is not in a shape to allow you to fully do-operate throughout the season. You should wait until you have the last number of vats completed, and sufficient money so that you will be able to work for the best interest of the Parish, for the purpose of securing the best result. It would be folly for us to attempt to co-operate with you at this time, as it would waste both Government and State funds."

Last year we worked systematically in eight Parishes, and this year we are working in the same manner in nineteen Parishes, and it is our fondest hopes that these Parishes will be released from quarantine this fall. They are giving excellent co-operation and the people, as a whole, are lending their splendid influence to the work and doing all in their power to see that the cattle tick is completely eradicated.

Last year the State Legislature passed a law which provided that tick eradication must be taken up over the entire State not later than the spring of 1918. Mississippi, Arkansas and Texas have also passed State-wide tick eradication laws. His excellency, the Governor of Arkansas, told you yesterday that they had vigorously legislated against the "Tick." Such action means that within the next three or four years there will be no cattle ticks in the States which are taking such strenuous action against the tick, or, if there are any in existence, it means that they will be located and absolutely under control. The tick must go. History has taught us that it does not belong in this country. It was first brought from Spain to old Mexico, and from there it has rapidly spread over the southern states; particularly, where the climatic conditions would best permit its multiplication. It is the southern people, with their splendid co-operation, who have decided that the tick is a nuisance; and they have further arrived at the conclusion that it is not only a misfortune but a disgrace to allow such an infernal parasite to destroy such a possibility of greater cattle raising in the South. It is possible to hinder tick eradication, and it is also possible to set it back a little; but, gentlemen, it is absolutely impossible to completely stop tick eradication. In other words,

"The Tick Must Go" 
it is a road-roller. Last year our records show that we had $1,516,000$ dippings of cattle in the State of Louisiana under supervision. That, you will see, is working a hardship on the ticks when you have over one and a half million dippings in eight Parishes in one season. You will readily see what the final results will be this year, we are going much over that, as our territory is larger and the work will be more extensive. In this connection I beg to state that last year we dipped the cattle every twenty-one days, which did not give us the satisfactory results desired. This year the Live Stock Sanitary Board have decided that all new Parishes engaged in the work of systematic tick eradication must dip their cattle every fourteen days. This action will prove two-fold; that is, it will mean the eradication of the tick in one season in any Parish, provided the people co-operate, and, as a result, will conserve the Parish, State, and

Opposition Fast Disappearing Government funds. So far the people are taking very kindly to the fourteen day dipping, and we anticipate very little trouble in carrying out such procedure this year.

In 1906 the Federal Government started tick eradication and at that time they didn't have any dipping vats and I don't suppose there was a dipping vat in existence. All disinfection of cattle was done by the greasing method with a stick and a swab saturated with grease and they were able to place a little of such solution on each animal. In this connection, you can imagine what kind of a job that would be if we had to grease a million and a half cattle in one season. It would take more than one season to do it, and when we get through the results would not be satisfactory. Of course, by this method various states succeeded in eradicating large areas from the ravages of the cattle tick, but such areas were located mostly in counties where one could quite easily find the cattle, but, if you undertook such a piece of work in many sections on this Cut-Over Timber Land, we would meet with nothing but failure. The people at that time, along in 1906, 1907, 1908, didn't know much about tick eradication, consequently they were very skeptical. The question was frequently asked, "Could it be done?" And, of course, there were certain classes that were quick to answer "No," with the explanation that we had ticks on every animal, both wild and domestic, and it would be impossible to maintain a quarantine over the wild animals. Today, the people look upon the matter in a very much different viewpoint, and the 
question they are now asking to the State and Bureau officials is : "When can you send a trained man here to supervise tick eradication in our locality?" Such requests are coming in already, at such a rate that we are unable to furnish supervisors at once to every Parish and County ready to work.

Next year the new state-wide Tick Eradication Law for Louisiana goes into effect, which means that this State will be a leader in the complete elimination of the cattle tick. When the State Legislature passed the law they very unwisely, for some reason or other, perhaps on account of shortage of finances, did not provide a sufficient amount of money to carry out the working of the law. The Governor of Arkansas told you yesterday that they had appropriated $\$ 50,000$ in their State to wage war against the cattle tick. This State hasn't but about $\$ 10,000$ to do what they expect to do with $\$ 50,000$. If the people of Louisiana are enthusiastic enough to pass a state-wide law for the eradication of the cattle tick, they should go before the Legislative Committee on Finance and demand that the proper appropriation be made. Other Southern States engaged in this work are furnishing large sums to meet all the demands of the work. Many Parishes in this State are carrying on tick eradication with their own funds without any assistance from the State. One Parish, particularly, in this State has built something like fifty public dipping vats within the last thirty days, and the State is unable to contribute one dollar towards such progress. A great many Parishes in Louisiana have been unable to do systematic tick eradication this season because they did not have the funds, and in this connection I believe there should have been some organization, perhaps financed by lumber interests, that could furnish each Parish with a sufficient amount of money to enable them to commence active operation. I believe, Mr. Chairman, that this would be a very co-operative movement as it would help the Parish in question, and the money so loaned would be drawing a reasonable rate of interest. $I$ have in mind one Parish in the northern part of the State where the Police Jury were willing to co-operate with the State and Bureau force for the purpose of eliminating the cattle tick, but they were absolutely unable to borrow money to conduct the work, and in this connection it is reasonable to believe that the law permitted them to borrow money, otherwise they would not endeavor to carry out such a program; besides, it is further evi-

More Money

Needed to

Carry on

Work 
dent that their credit was good. They had the disposition and the desire to work with us, but they didn't have the money, and if there had been some organization in this State that could have furnished them the money at a reasonable rate of interest they would have been working systematically at this time and undoubtedly be in a position to be added to the free area this fall.

One gentleman this morning struck the keynote, I believe, on this cut-over timber land proposition, when he said that these lands ought to be fenced. Such lands are raising cattle for people who do not own an acre of land. They own the cattle and, apparently, depend upon charity for the privilege of grazing them, and when you talk to such individuals about dipping their cattle they are inclined to develop opposition. Those are just the menacing conditions that exist over the cut-over timber land territory, and, you know, a menace located here and there may seriously interfere with a great organized effort. These people have no business to raise cattle, graze them on somebody else's property, and then keep up an opposition against a great piece

The Evil of the Open Range of constructive work like tick eradication. If these lands in such sections in the South were fenced we would expect no opposition from the individuals who. were using such lands, and it would also prevent, from a certain extent, the destruction of a number of dipping vats which has been going on within the last few months. A number of them have been dynamited in this State-I think about twelve or fifteen-and an equal number in Mississippi. Dynamiting, of course, is very destructive, and undesirable in such instances. But, after all, it is a large advertising factor, because it starts the people talking about something they never gave serious attention to before; that is, it separates the good fair-minded class from the criminal element to such an extent that the better class condemns such lowdown principles as the destruction of public property.

The cut-over timber lands are indeed great. Only day before yesterday I was riding through Washington Parish, which, of course, gave me the opportunity to observe carefully the cutover timber land section, and as one rides through such country he cannot help from being impressed with the better appearance of the country. The land is of a rolling nature, well watered and dotted here and there with little dense forests which can be controlled or allowed to spread. The character of the soil appears to be equal to the average and as Doctor Dodson told you this 
morning the expression "poor land" has no place in our vocabulary, and does not mean anything. I think, if some of these lands could be fenced in, cattle put on them in charge of competent herdsmen under the supervision of lumber corporations there would be great rewards gained, not only in a financial way but as an advertising medium. I know right now where there are over 6,000 head of cattle going out of this State within the next thirty days to Texas. It appears to me that they could be used to an excellent advantage on some of our cut-over timber lands in Louisiana. It would be a great advantage and I think an excellent investment to try and do something like that, particularly at this time of the year when the grasses are excellent. So, gentlemen, if there is anything you can do along the line just indicated, do it.

Another speaker said this should be observed from a military standpoint; that is, preparedness in the way of raising more food products. We may need preparedness today, but we will need it a year from today just as much, if not more. Consequently, it is never too late to get ready. Any effort, by any organization, in the way of financing this cause would make you gainers in the end. The State of Louisiana, we hope, will be free from the dreaded cattle tick within the next three or four years. In the outset there has been released over 300,000 square miles, which represents nearly one-half of the territory quarantined on account of the existence of the cattle tick. That, I think, is a very good record. It has been accomplished through the splendid co-operation of the Southern people, who have spent two dollars in this cause for every dollar spent by our United States Government. I thank you, Mr. Chairman, for the time you have given me. (Applause.)

300,000

Square Miles in Louisiana Released from Quarantine 


\section{Stumps and Their Practical Removal}

Experiments the South May Profit $B y$

I had prepared a talk before this Conference on the subject of "Stumps and Their Practical Removal," but after listening to every word that has been said here at this Conference for the last two and a half days I have decided to change it, and instead of talking in technicalities to tell you, first-or rather to analyze the land clearing situation roughly from an engineering point of view; second, to show just how we tackled this problem in Wisconsin and the good results we got from it; and third, to suggest, if I may, how the Southern states can profit by our experiences and our mistakes.

The modern engineering methods and modern engineering tools have not been given as much importance in the subject of clearing lands as they should be. Modern engineering practices will play a very important part in the development of our cutover land regions; but I would like to make a statement right now that may forestall some criticism. What I will say in regard to cut-over lands is due entirely to an experience in the Lake states and on the Pacific Coast. I don't say that the novel methods that we have worked out in Wisconsin can be wholly adopted by the South; but I do believe the methods of investigation and demonstration that we have been using are of interest to you.

Now, stump lands-I believe it will be generally admitted by those, especially, who own them, that they are not generally sought after by those people who desire new homes in cut-over lands. Now, why is this the case? The answer is easy-it is the stumps. It is the fear of the stumps that keeps people from the cut-over lands. If there were no stumps the Lake states or the Pacific Coast or the South would have no more of a development problem than do Illinois or Iowa. 
Why are people afraid of the stumps? Is it not because the methods used have been so cumbersome and the tools so primi- Drudgery of tive and used for so many generations that the people, generally, have gotten the idea that making a home in cut-over lands means long, slow years of laborious back-breaking toil? Now, is not that the case?

The reclaiming of Western lands by irrigation is just as hard; it is almost as slow; it is practically as costly in leveling them and getting irrigation in; but the people generally do not recognize that fact; it has not been given the publicity which cut-over land has; and, therefore, people going out into a new country will go to those places in preference to the cut-over land area. Even the artists recognize that clearing land is hard, laborious work. In the National Library, at Washington, there are seven or eight semi-circular paintings in the ceiling that depict various home scenes-religion, art, etc.-and the artist for labor has shown a picture of a man with a grub hoe, trying to grub out a fairly sized stump, and if that isn't labor I don't know what is. Such things no longer exist in land clearing, but, like a lot of other fears and superstitions, it will take some real education and rural demonstration before those ideas can be rid of in the minds of the people who are coming in and who already are in these cut-over lands.

We have shown in Wisconsin that we can reduce the cost. reduce the time and reduce the drudgery of land clearing, and we feel that just in the proportion that we have done those things, we have made the cut-over lands popular and desirable.

An organized effort, directed along engineering lines, will do a great deal to demonstrate to the people that such is the case, and a clearing house where all this information can be gathered together, inspected, and, if found good, given publicity; and if found bad, condemned; if such an institution can be formed, a How Wisconsin Began Organized clearing house, it will have more value than any other one thing, in my opinion, that can happen to the cut-over lands.

As evidence of these statements, I wish to offer the work of the Department of Agricultural Engineering at the University of Wisconsin. A year and a half ago a special branch was organized, the sole purpose of which was to deal with problems connected with clearing cut-over lands. Previous to that there was no exclusive agency in the Lake states where any man could 
get any land clearing information of value. The new fellows coming into Wisconsin-there are five thousand a year-those new fellows had no place to go where they could get any reliable information on land clearing subjects. It was something like the Dark Ages before arriving at the common method of preserving ideas. Already we have in Wisconsin, this spring, greater activities than they have ever had heretofore; and that, we believe, in a measure, is a direct result of our work and the work that we caused to be swung into line.

We gathered from all parts of the country the different appliances men have used-a piler from Georgia, a hand puller here, a steam rigger from the Pacific Coast, a side trip from Minnesota; and if they are any good we say so, and if they are bad we say so.

As specific illustrations of what we have done in the way of being a clearing house, I have brought these models along, and will take a few minutes to show them to you as a specific illus-

Free Informa- tration that there are scattered throughout the country and the tion Service for the Farmer whole earth a lot of perfectly good ideas, such as these, which men have worked, that have helped them to solve their individual problems; and those little ideas have remained right in their communities and have never been given any publicity at all.

\section{(A demonstration of the models.)}

The way we get those before the public: We make blueprints of them and these can be had for a small price. We sent them out free of charge for a while, until we began to get blanket orders for six copies of each one.

The materials that we have perfected ourselves, we do not patent; but we fix it so no one else can obtain it for private gain. They can use it, but not patent it.

Our largest single effort was to conduct two land clearing demonstration trains over the northern part of the state. This was a co-operative enterprise on the part of the railroads, who furnished the cars and carried them all over their line free of charge; the stump puller people, who gave us their men and paid their expenses; the explosive companies paid their part of it and furnished the explosives; the man on whose farm we stopped furnished the teams; and the merchant usually gave a free lunch or some other attraction. Each train had eight cars in it. We carried a crew of eighteen men. We did the actual 
work in the field. We divided up an area and put a different kind in each tract and then sent the various different kinds of equipment on the stumps. We didn't advocate any method of clearing. We just showed what dynamite and stump pullers would do alone and in connection with each other. In the evening we held meetings with the townspeople and with the farmers, in an endeavor to get them to talk about their problems and their individual problems, and what they could do themselves for their own salvation. Some of the specific things we accomplished were these: IVe gave a decided interest to the general land clearing men. We speeded up the work and helped to reduce the cost and remove the drudgery, and instituted, or encouraged, a follow-up system which is showing results this year as never before.

I might enlarge upon these points. As far as impetus is concerned, the whole country seems to be talking about stumps now and their practical removal. The boys are holding debates on it in the high schools and forming small clubs and associations of that nature. The 20,000 people who saw those demonstrations were enthusiastic over the things they saw. Rural credits have been greatly stimulated, and now the bankers are willing to co-operate with the farmers as they have never done before, in loaning them money for land clearing purposes. They realize that when he tackles a job of that kind, that bank cannot make a better investment than to furnish him the means of staying on his land and clearing it himself. I merely want to cite one instance of this kind. One of the bank officials said to us he wouldn't have a stick of dynamite on his land; "the only thing I use that for is to blow up the posters you furnish." Well, after a demonstration, here is what he came out with: (Showing a poster) "Farmers, let us help you clear your land," and they gave four instances where they will lend money: One, for fencing timber or land; two, for buying stock, dairy or beef; three, for developing silage or forage; four, for stumping your land.

Land has always been cleared too slow for rapid development, and that is one of the things we tried to show-to increase the speed. We wrote that if a man didn't have a team, that a one-man stump puller would do the work. Horse pullers are even better than the one-man pullers, because it takes so much power to pull a stump from the soil and your back has to be

Banks Loan Money for Farm Improvement

Land Clearing Trains Demonstrate Work

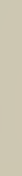




\section{Preventing}

Waste in Use of Dynamite

Four Billion Stumps to Be Cleared in South

Machines and Horses Now Do the Work multiplied so many times that it makes it slower. The horse stump pullers are equipped with accessories so that you can move from one place to another rapidly. These things speed the work up two, three and four times as fast, compared to the old methods.

The high cost of stump removal has been a very serious anchor to the progress of developing cut-over lands. We were able to show that where the people had been using 40 and 60 per cent dynamite, we could do absolutely as good work, stick for stick, with 20 or 30 per cent, and this has resulted in a saving of from $2 \frac{1}{2}$ to 6 cents per pound. The lower grades dynamite are safer than the higher grades, too, and they do better work. They do less cutting and are less shattering in their effect.

We have heard about this 76 million acres in the South. If there were in the neighborhood of fifty stumps per acre, there would be something in the neighborhood of four billion stumps in the South to be cleared. Now, I say, if that was done with dynamite, and you have been using 40 per cent, and by the use of 20 per cent you could save $21 / 2$ cents a pound, that would be a tremendous saving. I merely cite that as an instance where we were able to save the people of Wisconsin many dollars in the use of this low grade product that would do the same work.

Dollars are the controlling factor in land clearing, because a man will buy dynamite with all the money he can save. If, by any system, we can make this dynamite two, three or four times safer then he will clear two, three or four times as much land with the same expenditure; and with the combination of stump puller, pulling the stump first, and then cracking it-and one-third as much dynamite is required to crack a stump as to blow it entirely; that means that the man, with his combination method and proper equipment, can clear from three to five times as much land with the same actual cash expenditure.

The tremendous human energy that has been wasted in land clearing is something appalling. What we have accomplished, if we have done nothing else, is to almost eliminate the drudgery from land clearing. I don't say the work; there is nothing on earth that will enable you to get rid of stumps without work; but it is not that slow, back-breaking, monotonous toil. The outfit weighs about thirty pounds; a man can take that to a stump; that is not drudgery. He stands still while the horses 
pull the stump from the ground. It is not drudgery to work with the dynamite he uses; and it is not drudgery to pile the stumps. It has all passed from the man's back to machines and horses, and wherever we have been able to show we have removed the drudgery we have made the cut-over lands popular. To use a specific instance: On one demonstration a man came from Iowa to buy land, and he came to the demonstration and I heard him tell the man who had him in tow that if these men could clear land with as little back work as that, I can, too; and he bought 450 acres of land at $\$ 25$ an acre.

We don't try to pull green material. From our experience we find it will cost three times as much to clear green land as after four or five years. Put stock on it. Work it and seed it with whatever it grows best, and then put it to sheep and cattle, or to dairying. Goats are all right; they are the best browsers there are; and if you have a wide range, all right; but if you have it fenced you will have to put in a 38-wove wire fence and barbed wire or they will cut it.

As to the follow-up work: It was apparent that if we adrocated an equipment that would take $\$ 200$ to buy, it was plumb out of the realm of a great many of those settlers; if we could form a small society of three, four or five men-not more than five-and arrange for the purchase of such equipment as we would advise, that would reduce the cost to about $\$ 40$ apiece. Then we went to the banks and said, "These men want to get an outfit of this kind; they can probably clear five times as much land with this equipment as with their older devices"; and in every case the banks said they were willing to loan money up to half of that equipment, and three-fourths of the banks said they would loan all the money.

The Wisconsin Advancement Association, a group of men who have pooled their interests and paid 1 cent an acre for the advancement of those lands, organized a campaign for the purchase of stump pullers and explosives. Forty per cent dynamite had been retailing in the neighborhood of 17 or 18 cents. They proposed to put in in carload lots. They have now, together with the aid of the explosive company, been able to put in twenty carloads where there had been only cases sold before. In every case where one of these carloads were going in there had been only three or four hundred pounds sold during the en-

Deaden

Stumps Before Removal
Co-operative Association Work in Wisconsin 
Farms Now Cleared in Few Years

tire year. Just think what that means. If they can get a community that will purchase five of these stump pullers they can get it down to $\$ 112$ or $\$ 150$ instead of $\$ 175$. One of the land companies there just issued this pamphlet, which came in my last mail before leaving. In it they describe a clearing method which they are employing for every five thousand acre unit that they subdivide. They are setting aside a sum of $\$ 7,500$ to be used in the purchase of land-clearing equipment; and all that, of course, goes over to their purchasers. Another man has already organized several crews-he has thirty competitive crews-he has a very large area, and these men are working in a competitive contest, and at the end of the season prizes will be given them. This greatly stimulates the manufacture and the discovery of a great many devices that would not otherwise be used.

Now, don't get the impression that we preach any Utopian scheme in Wisconsin, where we have some way of getting the stumps out without work; but we have been able to show how the cost of clearing land has been materially reduced, so that now a man, instead of spending a lifetime, can clear up his farm in a few years; and we have practically removed the drudgery from land-clearing work; and we have made the cut-over lands popular in just the proportion which we have done these things.

I might just take a moment to explain what our future program is. We have been able to promote a great deal of interest in the land-clearing movement, but we have to find out some more before we can carry our demonstration further; and so there is a bill in the Legislature for $\$ 37,000$, which is asked to be spent over a period of two years in conducting further demonstration trains. Our plan is to lay off areas on various soil types of twenty acres; develop those and keep track of the methods that are used, and the time and hours of man labor and the hours of horse labor and the pounds of dynamite. If we can do all that we will then know which is the best way to clear land in the Lake states, and have a good idea for other people to follow.

I don't know whether or not the conditions we have, or the methods we have developed, will be of individual value to you; but I do believe that if you follow some of the things we have done you can expect to get some of the results we have accomplished. We have been working for the little fellow because there are some 50,000 of them already there. 
Now, as to the suggestions I have to offer, if I may: One is that, first of all, you establish an office similar to the one we have established. I might say that Michigan, Minnesota and Washington are establishing offices along the same line. There surely are in Louisiana. Mississippi, Alabama and the other states devices and information such as we have here, that will help your men, help your people in just the ratio they have helped ours. The first thing that ought to be done is to form a clearing house, where this information can be gathered together, and, if good, passed on. The second-and I might say that this can best be established with your various Departments of Agriculture and with your colleges, because the colleges are able to get more from the manufacturer by way of co-operation than almost any other single agency-the second would be to use your influence to provide proper funds for this work to be carried on. Next, start in with the collective demonstration, showing what is good and bad practice. You will know, then, what you will want to do with the investigations end. Try to co-operate, in all ways, with the banks, the railroads, the manufacturers of dynamite and the stump puller people. In that way you will get so many people together that the movement will be given so much momentum that nothing will stop it.

May I say just one word further? This is a little emergency poster No. 1 (indicating) that was published by the Wisconsin College of Agriculture, as a result of the demand for more food. We have begun to get results from this already; and I have one or two copies here in case anyone would like to see them. I also have one or two extra copies of our land-clearing poster. We have published a report of our land-clearing demonstration which we will be glad to send to any who care to have it; and we have in the press a land-clearing bulletin which is composed mainly of pictures. We feel that if we can depict land-clearing conditions and methods by pictures, that others can read the pictures whether they can read the English language or not. I thank you. (Applause.)

Suggests Central Information Clearing House for South 


\section{The Sheep Industry of the \\ South}

By F. R. Marshall

Senior Animal Husbandman Bureau of Animal Industry, United States Department of Agriculture

Importance of Sheep Raising in the South

Mr. Chairman, after this discussion I am in somewhat an embarrassing position, but I believe I am complying with the will of the majority, and will undertake to say, very briefly, some of the main essentials of sheep raising.

My subject permits me to cover the entire South, but I shall not endeavor to do so. I have been interested in listening to the discussions; and I take it that now we have cleared the stumps off the land and surveyed the soil; we have established pastures, and we have eradicated the ticks; I don't know whether to say we have established demonstration farms, but we have debated it.

You don't need to do all that before you talk about going into the sheep business. You could have done that without much of the other, but up to this time, I presume, the sheep business has seemed to you a rather minor and secondary matter: but if you will acquaint yourselves with the facts in that connection and with the methods of utilization of these lands, I believe you will no longer agree that the sheep industry is a secondary proposition.

I fwill explain to you the reasons for those views. In what I propose to outline briefly, I take it to be the consensus of opinion of this conference that at least a large part of these cut-over lands must, for some considerable time, at least, be used for grazing purposes. I don't know how much or how long. When you come to consider a grazing proposition, you have sheep and cattle mainly to think about.

The thing that has impressed me most in this connection. and in the conservative constructive thinking along this line, is a statement made by a gentleman that after he studied the means 
of utilizing his lands, he came to the point where he did not want to dispose of them.

The possibilities and opportunities in sheep raising are much less well understood than in cattle raising. There have been a good many reasons for that up to this date. Those reasons no longer exist. During the last five years, or two years, the sheep business of this country has come in on an entirely new basis. For your guidance in the future you don't have to study the history of the question at all.

The reasons for saying you don't have to study the history of the sheep business are briefly these: $U_{p}$ to this time the sheep of the world have been kept on the new lands, where they could go into the sheep business without preparation, and because in many cases they would produce and carry nothing but sheep. That has been the case in our western states, Australia, South America and Africa and other countries. In those World Scarcity of Sheep areas, however, those conditions have passed. Those grazing lands are being used for other purposes. Ultimately, no doubt, they will carry larger numbers of cattle and sheep than they carried when used for pasture purposes. In the meantime, there is a very serious shortage of sheep meat and wool the world over.

Those conditions are disappearing and, as a consequence, the prices of sheep products, especially, have gone up. We face today a condition where lambs are worth 15 cents a pound on the hoof. When you consider it is a safe proposition to put a lamb on the market at 70 pounds, you will understand something of its possibilities. At the same time it is hard to say, without having seen the market reports of the hour, what the prices of wool are. They are very high, but largely because of conditions that were in evidence before and will exist after the war.

This passing of the pasturage parts of the country has been particularly noticeable in our western states during the last three or four years, and is going further. We still have in the public domain, as stated by the Commissioner of the Land Office. something like 280 or 290 million acres of land which has been used by the stockmen of this country for both sheep and cattle grazing; and as to a comparison of the possibilities between sheep and cattle let me make this statement: that with present values and circumstances, and the adaptability of the country, it is a 
America Importing Vast Quantities of Wool

\section{Cut-Over Lands Ideal For Sheep Raising}

pretty narrow choice, and it is mainly a matter of taste as to whether the man takes sheep or cattle for pasturage.

Those lands are being taken up very rapidly, and during the last few months, especially, there have been something like $4.5,-$ 000 applications for those grazing homesteads. It is altogether probable that ultimately again a large part of those lands will carry more stock than they have now; but I do believe it is more certain that for a considerable time they will carry much less stock--they will ship eastward much less cattle and wool than for some time past. Taking in connection with that fact the further fact that other countries are in the same position; and still further the fact that this country manufactured, during the year ending June 30th last, over 800 million pounds of wool. While we manufactured that we grew less than 300 million pounds. The rest came from the countries mentioned. The consumption in other countries is increasing; the production is decreasing; and we are up against a serious proposition. There is room to dilate as much as one may wish upon the patriotic phase of the question; but I submit it to you only as a business proposition, to help meet the demand for an increase of the sheep population somewhere in this country.

The cut-over lands of Michigan, Minnesota and Wisconsin are well adapted to put sheep on them. This increase of lambs and wool, which must be had, can only come from two sources. The one we have been thinking of most heretofore is that of the farms of both this country and other countries. The sheep business will increase very materially there, but it will be a slow increase and it will have to be along lines yet to be worked out. Outside of the countries not ready for the business. I do not believe there is any section which is so ready to go quickly into a considerable wool or lamb proposition as the cut-over lands. With the opportunities you have, of relatively low production, I only wish to submit to you that the sheep business, for those who will understand it and study it from a business standpoint, is thoroughly safe and practicable.

I am not going to renew, or take part, in any debate as to just how you will get the information other than to say that if anything has been done by disinterested parties in this part of the country to show the possibilities of keeping sheep, I very much regret to say that it has not come to my attention. The nearest 
we can come to getting a line on it or a parallel case is found in New Zealand. That is too far away to interest you fully, but I want to call your attention to the fact that there is in New Zealand a set of conditions that compares closely with those of the cut-over lands. The soil compares very closely in kind and the climate and rainfall are the same. Through the pressure of circumstances those people residing in that country have taken up the live stock proposition and provided pastures that will support live stock all through the year. Where they have worked that pasture proposition out and studied the live stock business, they have found that their lands were paying dividends on their valuation equivalent to $\$ 200$ an acre. Only there, that I know of, can you go to find a demonstrated proposition as to sheep raising, that will show you the actual net expense and possible receipts on an acre of pasture; and you must also consider that in building up that system they have been under the handicap of marketing their product five thousand miles away.

Just to what extent and in what way the sheep proposition can be taken up, I am not ready to state in any detail as yet. It will have to follow the same general lines I have mentioned. First, however, as with cattle, the natural or artificial pasture is the primary consideration. The sheep differ particularly from the cattle in this way, that a good marketable carcass of lamb can be raised under pasture conditions without the use of any material amount of grain. It is possible to produce a useful and salahle carcass of lamb without grain at all. Grain is not essential to the production of wool, so that with sheep you can have two finished products from pasture alone.

Sheep will not thrive under conditions where their feet are continually wet. If it is continually wet or swampy, you will have trouble. They will eat a greater variety of plants than cattle, but if your main object is to clean up brush you can do it with goats and you will have a very satisfactory job.

Getting down to the possible advantages of sheep in comparison with cattle on this land, you have to consider that the tick proposition is not serious with sheep. The authorities have stated that the sheep are in no way concerned with tick. While sheep have no ticks, however, they have their own peculiar troubles, which are less serious in some ways and can be avoided. The main factor in the trouble of sheep health is that which concerns itself with stomach parasites. There are thoroughly prac-

Sheep Thrive

Without

Grain Food 
tical systems of controlling and preventing the troubles from that source. One of the systems is to give sheep a sufficiently wide range. Another way is to use the sheep on pastures while the cattle are not there. I said I would not endeavor to outline a detailed system of the proper methods of handling sheep, but whatever system can be safely attempted early in the game will necessarily be somewhat along these lines.

I will say that sheep can be used on the same ground with cattle, to the advantage of both. I know some of you that have traveled in the West and have read the old-time stories have recollections of the bloodshed in those western countries due to the

Combining Sheep and Cattle Raising feuds between cattle and sheep men, and you will find that a large proportion of them have been over the possession of the ground. The solution of the whole question has been found, and it is this: When sheep and cattle belong to opposite and opposing owners, their sheep do hurt the pastures; but when the same man owns both, they get along very well to the advantage of both.

I don't believe you are likely to make a success in the preliminary stage if you take up sheep raising as a side line. It can be done with small units, but not with the size of pastures you are operating with. Sheep are peculiar to people who have never studied them; but there is nothing about their health, management or breeding that intelligent study cannot master. Outside of the fencing proposition and alternating with cattle, I think the system that has the most immediate possibilities is that of the straight western ranching proposition; and I believe

Ranchmen, Crowded in West, Now Ready to Come South that some of the men being crowded out of their holdings in Wyoming and Montana could be interested in these lands to the extent of making a fair try of the proposition. If you will do as those men do you will need a unit of a thousand ewes, and possibly up to 1,500 , but hardly less than a thousand, with a herder with them day and night. That helps to take care of the dog proposition and gives them proper care. That western herder is with the band all the time. He does not stay in one place all the time, but keeps them moving around. He works them that way and he is on watch all the time. By keeping them on the move the danger of parasitic infection is mainly avoided. Of course, that involves some expense; and the kind of business that calls for it is one which keeps sheep both for lambs and wool. That plan may seem at first to contrast rather poorly 
with existing Southern Hocks having anywhere from eight to twenty thousand ewes with a big loss every year, and representing a value of perhaps $\$ 3.00$ each with an income of $\$ 1.00$; but with more improved sheep to produce lambs marketable at an early age as well as wool, even with the extra expense of herding and attendance at lambing time the net results are much in favor of the latter plan.

\section{Possibilities of Cut-Over Lands}

\section{By J. A. Evans \\ Assistant Chief, States Relation Service, United States Department of Agriculture}

$\mathrm{Mr}$. Chairman, I have been convinced for some time that this meeting is already "fed up" on farming talk, and I am therefore going to take the liberty of talking to you for a very few minutes about some other phases of the cut-over land problem that have suggested themselves to me during the course of this evening.

I have been interested in the cut-over land problem for many years. For more than thirteen years $I$ have been connected with the Department of Agriculture in what has been known as farm demonstration work in Texas, Arkansas, Louisiana and other Southern states, and much of our work has been in the cut-over land sections. I yield to no man in my belief in their possibilities. It should be stated, perhaps, that there are now in the fifteen Southern states more than seven hundred men engaged in farm demonstration work, a large proportion of them working directly on cut-over lands. These agents are engaged in helping farmers to make their farms more productive and profitable by demonstrating the actual practice of better methods and the application of scientific principles to the farm, and keeping records of the results obtained.

In preparation for this meeting I addressed letters to more than one hundred of these special men in cut-over land sections and secured from them records of actual results on such lands 
Phenomenal Yields on CutOver Lands

Settler Must Be Adequately Financed and information on various subjects affecting their beneficial use. It has been demonstrated over and over again on every type of soil in this region that these cut-over lands can be made very productive. On thousands of demonstration farms with all the staple crops, yields running from fifty to two hundred per cent over and above the average of the state have been secured. Yields of from twenty-five to thirty bushels of corn have been usual on such lands, but many phenomenal yields running as high as two hundred bushels per acre have been secured. In cotton we have produced from one-half bale to two bales per acre. and similar results with every standard crop have been secured.

In view of such results, absolutely proving the great possibilities of these soils, the question asked by your chairman at the beginning of this meeting is pertinent. What is the reason these lands remain unsettled and are apparently so unattractive to the average investor? I am a Southern man, and I believe--yes, know-cut-over lands of the South are destined some day to provide homes for a great multitude of happy, independent, and prosperous farmers. But here is the situation. With things as they are, not one man in ten-and many careful observers with long experience in cut-over land sections say one in twenty-five -have any possible chance to go onto these cut-over lands, buy them, pay for them, and establish a home unless he has ample resources or some outside means of subsistence, particularly for the first two or three years. It can't be done. A gentleman in the meeting this morning stated-and it is a well known fact-that it was usually the third purchaser that was able to stay on any particular piece of land, and he considered this as an unavoidable condition. What makes it necessary? Simply this: these people have been brought to the South under almost fraudulent representations of what they could do on these lands with little capital. Inspired by the glowing pictures painted by land promoters and sellers, clerks, stenographers, school teachers, preachers and people engaged in other occupations--not farmers-have been tempted to invest their little savings and come South in the belief that from a few acres they could wrest an immediate living and future independence. Practically all their money is taken from them as a cash payment, and the little left is used up in moving to their possessions. To go on cut-over land without capital or without outside help or assistance to try to make a living is a hopeless task. They fail; they are bound to fail, and then they go home and "cuss" the country. 
After two or three have thus sunk their little "wads" the third or fourth man comes along, and, building on the foundation laid by the loss of capital of the others who preceded him, he may be able to stick and make a living, and if so, by and by, he develops a good farm and becomes a successful, prosperous man, because the possibilities are there. I could take you into any cut-over land section and show you men who have made a success on these lands-show you substantial and prosperous farmers having farms worth from $\$ 50$ to $\$ 100$ an acre, some perhaps who would not take $\$ 100$ an acre for their farms-built up from these cutover lands. But they purchased these lands for something like what they were worth and on long credit. They paid, perhaps, $\$ 2$ or $\$ 3$ - or at most $\$ 4$ or $\$ 5$-an acre and while developing the farms had work in the sawmills adjoining so that they were enabled to support their families, and they and their families worked mornings, nights and holidays in clearing and in otherwise developing their land. In this way, after a few years their farms were gotten into shape where they began to produce well and be real farms. But a settler today on cut-over land hasn't, as a rule, the same chance. The opportunities for outside labor at remunerative prices are not frequent and for the most part the men who purchase cut-over lands today have to depend on the land itself or on surplus capital for a living from the start.

Now you can't, as a rule, start on cut-over land without capital or without outside employment or help of some sort, and make a living on it for the first year or two. Why? liecause as has been told you-and it is the truth-these lands are naturally poor, some more so than others. They will grade from fair to poor but practically all of them are deficient in the three things that are essential for a fertile soil, that is, humus, or vegetable matter, phosphorous and nitrogen. In addition to this the mechanical condition of the soil is generally bad, so that it takes careful farming with proper rotation of crops and the use of legumes to build them up and it is not until after two or three years of this kind of handling that they begin to produce well.

As an offset to these disadvantages, on the other hand, is our wonderful climate, good seasons, the great variety of crops we can grow, including legumes or soil building crops, and the responsiveness of most of these soils to right treatment, the rapidity with which they can be built up and made fertile. You take these cut-over pine lands, particularly those soils with a deep red clay

Soil Must Be Built Up
The Reason for Some Past Failures and Successes 
Cut-Over

Lands Potentially Finest in the World

subsoil and sandy loam top soil, and I stand here to affirm that there is not potentially a finer soil on earth, one more capable of being made to produce abundantly-but it takes time, money and much labor to put it into condition to do so.

I firmly believe, however, that it is feasible to colonize the cut-over land of agricultural value. There has never been a time when so many people were looking with longing eyes toward the South. Thousands of letters are received at the Department annually from all parts of the world inquiring about different sections of the South and many of them making specific inquiries regarding colonization projects in the cut-over land sections. As the majority of these letters find their way to my desk, I have endeavored for years to keep in touch with such developments in this section. Wherever I have seen advertisements of colonization projects I have written for their literature. I have carefully noted such advertisements in all the agricultural papers and in other ways have tried to be in position to give intelligent advice to such inquirers. I am sorry to have to say that in the great majority of cases my conscience would not permit me to recommend such projects to intending purchasers. Most of them, as shown by their letters, were people of small means who were dreaming about building a home in the South and expecting to invest the savings of a lifetime in the undertaking. Notwithstanding my interest in this section of the South, I have felt compelled, as a rule, to advise against the investments contemplated, and I shall continue to follow this course as long as conditions surrounding the average colonization scheme remain as they are.

Method of Colonization Suggested

What, then, should be done to make this section attractive to homeseekers and to render it possible for the man with small means to succeed?

First-The owners of this vast domain should themselves undertake the handling and disposition of it. As a preliminary step the land should be surveyed and classified into agricultural and non-agricultural lands.

Second-Then you should put a reasonable price upon ita low price-get down to bedrock. It is unreasonable to expect to sell such lands at the prices which have been asked, as a rule, by the colonizers and promoters, prices ranging anywhere from $\$ 20$ to $\$ 40$ per acre. Consider for a moment what the purchaser 
of these lands for farming purposes is up against. The original price of the land is only a small part of his necessary expenses in building a home. To grub and clear the land ready for the plow without removing the stumps will cost him anywhere from $\$ 7$ to $\$ 10$ an acre; fencing, $\$ 5$ or $\$ 6$ an acre; necessary buildings, even of the most modest sort, from $\$ 5$ to $\$ 10$ an acre, and then, if he is to have a real farm, the stumps must be removed so that he can use improved machinery, and this entails an additional expense of anywhere from $\$ 10$ to $\$ 25$ an acre, depending upon the character and number of the stumps to be removed. And, as has been pointed out, one or two years' cultivation is necessary before the land can be brought to a fairly productive state. You can afford to sell these lands at a reasonable price. They were purchased for the most part with the timber standing at from 75 cents to $\$ 3$ or $\$ 4$ an acre. They are carried on the tax rolls of the various states today at from $\$ 1$ to $\$ 2$ an acre. Personally I do not believe that any of the cut-over pine land in its natural state is worth for agricultural purposes more than $\$ 10$ per acre, and the greater part of it is not worth that.

Third-It must be sold on long time and easy terms with practically no cash payment down or for the first two or three years. These lands will not, as a rule, attract the man with Sell on Long Time and Easy Terms. money. They cannot compete with the prairie lands and improved farm lands in that market. Your purchasers will be, as in the past, people of small means who are hungering and thirsting for homes, but have not sufficient capital to buy improved farm lands. They must be sold on such terms that practically their entire capital can be devoted to improving the land and getting it into a productive state before much of a payment is required of them. And then when you have got them on the land you must be prepared to give them help financially and otherwise. You should work out some system by which, if necessary, you can loan them money for buildings, for fencing. It may be necessary and advisable to loan them money to purchase equipment, particularly a cow or two, a brood sow or two, and other live stock, and for seed and fertilizer. Once a man is located on your land you must do everything possible to see to it that he succeeds, for each success will bring you many additional purchasers, but each failure will turn many prospective purchasers away. You may possibly find it advantageous to clear up large quantities of land and get them ready for culti- 
Stuntps as a Valuable ByProduct

vation before putting them on the market. This is a proposition which is entitled to careful consideration.

I was very much interested in the remarks of Mr. Alexander regarding the utilization of the stumps and the value of the by-products which might be secured therefrom. This is a matter which should be very fully investigated. If, in fact, there is twenty-five dollars' worth of by-products in each acre of stumps, it would be a sin and a crime not to utilize them. It may be that the inability to settle these lands heretofore has been providential in order that this vast wealth which otherwise would have been wasted may be conserved. I was very much interested in some photographs which were shown me today by Mr. Redhead. our Assistant State Agent in Louisiana. He tells me that in Tangipahọ Parish there is a man who at the cost of $\$ 300$ has erected furnaces and is converting his stumps into various by-products. He has found that he can pay all expenses of removing the stumps and realize a profit at present prices of $\$ 10$ to $\$ 15$ an acre. It would seem feasible, then, for companies owning large tracts of land to either build plants and remove the stumps themselves or finance settlers in building these small plants in order that they might from the by-products of the stumps not only pay the expenses of clearing their land, but get an income sufficient to support their families until the farm is put into condition to begin to return a revenue.

You must also make some provision to see that they are given the right kind of advice and instruction. Even good farmers from the North make serious mistakes and frequent failures when they come South because conditions are so different. The one thing I am always careful to advise people from the North to do in coming South, is to get in touch with the county demonstration agents and be guided by their advice as to what and how to plant and how to cultivate and handle the crop. Provision for safe, conservative advice along this line will be doubly important to settlers on cut-over land because the majority of them will have little previous farm experience.

Here is where the Department of Agriculture stands ready

Goucrnment Will Co-operate with SetHer to co-operate with you. Thanks to the Smith-Lever bill, the Government and the colleges are now prepared to extend aid to new settlers on cut-over lands as never before. They will shortly have trained, skilled agriculturists in every county, and 
in most of the counties beside, a trained home economics agent who will be ready and willing to aid new settlers. If you will can settle upon your lands with a reasonable show of being able simply do your part and make conditions such that homeseekers to succeed, we will help them to do the rest.

\section{The Cut-Over Acre-What Is It Worth? \\ By William R. Lighton \\ Fayetteville, Ark.}

Producing power is the only real measure of value of any source of wealth, whether it be a railway, a manufacturing industry, a mine, or an acre of agricultural land. So, as a matter of course, we must know producing power before we can judge of value.

Standard oil stock, steel stock, the soundest industrial stocks on the list, would be going a-begging if nobody had ever taken the trouble to find out anything about their earning capacity. That, and that alone, fixes their worth.

By the same token, the largest single item in the wealth of the Southern states, their undeveloped land, hangs heavy and remains undeveloped simply because there is no general and accurate understanding of what it is able to do. Today, for just this reason, we are talking about the future use of this land as a problem. So it is; but the problem does not lie in the character of the land itself. The trouble lies in the poverty of our knowledge. If the plain facts were known, then there would be no problem at all. How could there be, in a time when the remotest corners of the continent have been searched for new lands which might be made fruitful even with vast expenditure of money and labor; in a time when far-off deserts have been painfully reclaimed, when the forbidding semi-arid regions have been peopled, and when the ceaseless cry of the world is for a supply of food to keep pace with increasing needs? Yet here are these lands of ours, countless millions of acres, not unproductive, but their productive capacity a matter of blind guess-work in the minds of most of us.

Value of CutOver Lands Little Known or Appreciated 
Well, what are the facts? It will not do to say, in a loose, free-and-easy way, that the lands of the South are as fertile as any in the world. There has been too much of that sort of talk. What we want now is exactness.

But exactness of statement of the facts is very difficult. It may interest you to know that it has taken many days of hard, patient digging in dry masses of census tables to gather the few plain figures I am presenting to you. It has not been possible to find them elsewhere.

Note that in this comparative statement I am not dealing with exceptional conditions or unusual cases. I am giving average figures for whole states over a ten-year period.

For the ten years from 1900 to 1909, inclusive, the state of

Arkansas CutOver Lands Out-Produce the Rich Corn Belt
Arkansas showed a greater average value per acre of staple farm crops than was shown by the richest states of the great corn belt. For those ten years that average crop-value in Arkansas was $\$ 22.04$ per acre. Mind you, this does not include cotton, rice, sugar, fruit or truck crops, but only grain, potatoes, hay and forage common to the whole Mississippi Valley.

For the same period, Illinois showed an average value per acre for the same products of $\$ 17.24$. In Iowa the average production per acre was $\$ 14.52$; in Indiana, $\$ 16.35$; in Ohio, $\$ 17.62$; in Missouri, $\$ 13.54$.

This production in Illinois represented a gross return of 18.1 per cent on the average value of farm lands. In Iowa the return was 17.5 per cent; in Arkansas it was 157.4 per cent. That is to say, Arkansas land with an average valuation of only \$14 an acre yielded half again as much as the Iowa acre whose average valuation was $\$ 83.00$.

What gave the Iowa acre this greater valuation? Not its better production, as these figures show. Not its more favorable location, for Des Moines and Little Rock lie at almost exactly the same distance from the national center of population. which is approximately the center of consumption of farm products. Not better transportation facilities. for Arkansas products reach the great consuming markets as directly as those of Iowa. Indeed, the odds are rather in favor of Arkansas in the matter of access to markets.

There is only one true explanation of the higher level of Iowa land values. The facts as to the producing power of the Iowa 
acre are advertised and thoroughly known; the facts as to Arkansas are unadvertised and wholly unknown. The valuation of the Iowa acre is living tribute to the importance of intelligent publicity.

Iowa Profiting by Intelligent Advertising

The time is coming inevitably when the neglected lands of the South, and not the lands of the Corn Belt, will be the center of production of the staple foodstuffs. Why? Because acreproduction in the South is greater and production-cost almost incomparably less.

The good Iowa acre produces in a season only 500 pounds of pork, at a cost of 4 to 5 cents a pound. The Arkansas acre, in the longer season of the South, produces 1,000 pounds of pork at a cost of 2 to $21 / 2$ cents a pound. The Arkansas Experiment Station has produced 1,252 pounds per acre at a cost of $13 / 4$ cents. On my own farm in the highlands of Northwest Arkansas the average production-cost of Irish potatoes is from 10 to 12 cents a bushel. An acre of well-established southern Bermuda grass pasture will carry six head of grazing cattle over a period of 6 to 8 months, whereas in Iowa an acre of pasture will hardly carry one grazing animal through the shortest summer season.

These are suggestive and typical items. I wish I had time for dwelling more fully upon the comparison.

The key to the solution of this cut-over land problem is a consistent campaign of the right sort of publicity-not for the fact that low land-prices offer the speculator a stunning opportunity, but for the bigger fact of producing power. Let that power become known, and settlement and development will follow with absolute certainty.

About the worst thing that might happen to the South would be to have the exploitation of these lands fall into the hands of the speculator or the professional promoter. The best thing that might happen would be the beginning of intelligent publicity of the sort which will make its appeal to farmers rather than to mere adventurers. With such publicity we shall open a plain, straight way for the soundest of all development, a development which will be free of all the insanity of "booming," a development which will with absolute certainty convert this burden of millions of acres of unused land into a producing asset of incalculable worth. In such publicity I see the South's chief hope for a future whose soundness will be impregnable.

South Should

Make Its

Advantages

Known 


\section{Shortage of Raw Material- the Demand Increasing}

\section{By A. C. Bigelow}

\section{President, Philadelphia Wool and Textile} Association

Gentlemen, I want to express to you my appreciation of the honor of having been invited to come here and address this meeting. I have come 1,500 miles for that purpose; and I think you will understand that I should not have made such a long journey down here if I had not been impressed with the importance of this gathering and the importance of that which I wish to present to you in regard to the agricultural proposition, especially sheep husbandry.

It is probably worth while to explain to you briefly the de-

Early History of the Sheep Industry in America
The Herdsman Moves Westuard velopment of the sheep industry in this country. As you will readily understand, it was natural that it should start in the Eastern states, as the original Merino sheep came mostly to us from Spain in the early part of the last century. The New England states in the early days showed quite a rapid development, and Vermont was at one time a large sheep producing state. In that state the number of sheep were as follows:

$\begin{array}{ccc}\text { Vermont- } & \text { Year } & \text { No. of Sheep } \\ 1840 & 1,681,819 \\ 1860 & 752,201 \\ 1880 & 439,870 \\ 1915 & 47,416\end{array}$

Following the advance westward of population, sheep were largely kept in New York State, Pennsylvania and Ohio. During the ten years from 1870 to 1880 , there were close to $5,000,000$ sheep in the state of Ohio. In 1890 the number dropped to 4.000,000 , while in 1915 they were reduced to 2,100,000. Still advancing westward, and following the areas of cheaper lands, we find that Texas had as follows: 


$\begin{array}{ccc}\text { Texas- } & \text { Year } & \text { No. of Sheep } \\ 1880 & 3,600,000 \\ 1890 & 4,260,000\end{array}$

But with the advance of the farming element, restricting the areas of cheap land, Texas dropped in 1915 to $1,600,000$ sheep.

In California we find as follows:

$\begin{array}{ccc}\text { California- } & \text { Year } & \text { No. of Sheep } \\ 1880 & 5,727,000 \\ 1890 & 3,373,000 \\ 1915 & 1,900,000\end{array}$

During this early period it should be noted that sheep were kept for the wool product alone. We were educated as a beefeating people, and our immense supplies of cattle made beef cheap. Mutton at that time was an insignificant factor in the profit and loss account. This situation has now changed completely. The supply of cattle is decreasing so materially that beef is advancing greatly. Mutton and lamb have been improved in quality, and there is a good demand for it today. Results carefully taken at the Pennsylvania State College show that the mutton product of sheep represents about two-thirds, whilst wool today represents about one-third, making wool a by-product; so that the market fluctuations in wool, which will always occur to a certain extent, will not have any great effect on the profit account of the sheep industry.

With restriction of the cheap lands in Texas and California. the bands of sheep were driven up into the mountainous grazing limits of the northwestern section, and there we find for many years a great increase in the number of sheep, especially in the states of Wyoming. Idaho and Montana. But here, too, within the last few years, we can find the same cause operating a decrease in the flocks-the homesteader and farmer are coming in, the ranges are restricted, and production has decreased. In effect, the whole industry has moved like a great wave, on the lines of least resistance, utilizing cheap grazing lands as long as they were cheap, and showing a decrease as soon as they were occupied for agricultural purposes.

The great Northwestern grazing territory, comprising the states of Montana, Idaho, Wyoming and Oregon, containing vast areas of free or very cheap grazing lands, has been the great

W'ool, Once C'hief Factor, Now a By-Product

Western Gruzing Area Constantly Dunindling 
source of wool and mutton production during the present century. These four states in 1916, out of the total wool clip of the United States of $288,000,000$ pounds, produced $86,255,000$ pounds, or about thirty per cent.

There has been during the past seven years, however, a continued shrinkage in the production from these four states, caused by the overstocking of the ranges. During the session of the last Congress an Act was passed, opening up the Government lands in this section to the farmers in tracts of 640 acres. We sent a special agent into this section, to make a survey of conditions and to locate breeding stock; and the reports we have received from him and from other sources, indicate that there is a

Sheep Raiser Looks to South as $\mathrm{Fu}$ ture Field great rush of farmers coming into this section, taking up these 640 -acre tracts, and in consequence the range is being broken up to such a great extent that those who have been maintaining sheep there are being forced to dispose of their flocks, and the evidence is conclusive, and our records show, that there will be a decrease during the next two years of about thirty per cent from this section. And, moreover, the evidence shows that there will be a continuing decline of production from this section for many years to come. It is quite evident, therefore, that the population of the United States will be seriously affected by this rapid decline in this great sheep territory, and there is only one source left open now from which we can obtain an increase of sheep production, and that is in the farming sections east of the Mississippi River and in the unused land areas of the South.

In all matters, political, social and economic, change is the law of the universe. As in the past, economic conditions operated to drive the shepherd of the East our of business, and to develop the great sheep interests on the western grazing lands, so today again, economic conditions are forcing the western flockmaster out of business, and opening up a favorable opportunity for the profitable maintenance and development of the sheep industry in the older sections, which have been so long neglected.

We, of course, understand that the abnormal conditions created by this great war will not continue indefinitely. The demand for the armies of the warring nations is tremendous, and there is a certain amount of credit inflation, which tends to advance prices above a normal level. It is quite natural that the question arises as to what will be the conditions as to prices 
when the war ceases. This matter has received the most careful attention, and has been closely studied by those who are thoroughly competent to form an opinion, so far as human judgment can do so, on this matter. The result of consideration of this indicates that whilst we must look for some liquidation, and whilst it is expected that prices will be to a considerable extent lower than they are today, yet it is generally agreed that prices, both for meat and for wool, must be maintained for many years to come at a very much higher level than existed before the war. In the ordinary course of clothing consumption, a great part of the clothes which have been in use are converted again into wool fibre in the form of shoddy, and so used in connection with pure wool to produce woolen clothes. This reserve supply, as it may be called, of wool fibre, has been to a very large extent exhausted by the destructive agencies of war. Moreover, the great sheep countries of the world have been showing a decrease of production, and it is beyond doubt that war in this case has also been the means of a much further decrease on account of animals being used to provide food for the soldiers in extraordinary quantities.

In connection with what will occur after the war, two other points must be taken into consideration, and the evidence of this is conclusive. One is that in all the warring nations the demands of the army for clothing have been so great that the civil population has been afforded a very inadequate supply of woolen clothing, and in consequence, when the war ceases there will be a tremendous demand for wool to re-clothe, not only this civil population, which is now non-combatant, but to supply those who are now using uniforms with the ordinary clothes of the civilian. The second point is that the nations at war will, on the cessation of hostilities, be forced to engage in the fiercest kind of commercial competition, to regain for themselves the markets which have been lost during the war, and to operate their industries, in order to obtain an income, from which they may be able to pay off the interest on the enormous debts which they have contracted. And there is further evidence that the British Empire, controlling, as it does, two-thirds of the wool supply of the world, will maintain for a long period after the war, a strict control of these wool supplies, in order that she may conserve her industrial interests, of which none other are more important to her than those of woolen manufactures. In this connection, I

Tremendous After-War Demand for Wool

Expected

High Sheep

Prices to Continue for Years 


\section{Britain's}

Wool Supply to be Kept at Home
Sheep Raising as a Profitable Investment present to you a short extract from an address delivered in London by Mr. E. F. Hitchcock, one of the officials of the Department which has control of raw material for the manufactories of the British Empire, as follows:

"The British Empire produces 64 per cent of the world's exportable merino and crossbred wool, and the rest is produced in South America. Therefore, you see that the position of the British Empire so far as wool is concerned, is a very strong position indeed. I doubt whether there is any raw material, except perhaps rubber, which is of so great importance as wool, and of which at the same time the British Empire has a virtual monopoly as it has for wool. But the importance of the British Empire wool should not merely be measured in terms of quantity, it has also to be measured in terms of quality. The very finest merino wools most in demand for very fine cloths are grown in the British Empire. Australian merino wool is the finest wool on earth. You cannot get it elsewhere, it is not grown elsewhere, in any appreciable quantity at all. The British Empire controls 80 per cent of the world's merino wool production. I hope later to develop the enormous importance which raw material, wool especially, is going to play in the economic struggle after the war.

Nothing appears to me so important as the reservation for our own needs of all the raw material that we want after the war. As food is to the individual, so is raw material to industrial countries, and unless we make quite sure that we have sufficient supplies, we shall find that our industrial development will be very seriously retarded."

The situation which presents itself to us, therefore, on account of all which I have brought to your attention, shows that population for a number of years has been encroaching upon our production of food and of raw material of wool for clothing. It shows that the conditions brought about by the great war in progress has developed a world shortage of wool supplies, and it shows that our own domestic production in the great Northwestern territory will develop a very decided decrease from that section, which has been such an important factor in our wool production. It shows that after the war the demands in the warring countries to fill the needs of the civilian population is going to be tremendous. Based on all the premises, therefore. submitted regarding the extraordinary market which will be 
opened for wool especially, and for the product of meat which our rapidly increasing population must have, it is safe to assume that prices will be maintained upon a very ligh level, and that the opportunity presents itself to those who have lands suitable for the maintenance of sheep, to engage in sheep husbandry as a very profitable business.

I have been engaged during the past year in presenting this situation to our Northern farmers, in order that they might be fully aware of the fact that today sheep husbandry affords a wonderful opportunity for them to add to the profits of farm production. I have come here to present to you this information in regard to the sheep industry, that you might seriously consider whether or not the great areas of land which you control, and which I understand are largely unproductive today, may not be utilized and made profitable by engaging in the maintenance of sheep on these lands. I do not pretend to be an expert, with sufficient knowledge to inform you adequately as to how suitable the lands you control are for this industry. To obtain that information, you have at your command the services of the United States Department of Agriculture, the State Departments of Agriculture, and your Agricultural Colleges. It will be advisable that you should solicit from them a proper survey, which would establish to what extent your lands are adapted for keeping sheep. It is worthy of note, however, that practically the same parallels of latitude north of the equator run through this section-that is to say-30 degrees North Latitude-as run through the great wool-producing sections of Australia, Cape Colony and the Argentine Republic. Another point to be considered is the fact that experience shows that the sheep readily adapts itself to greatly varied conditions of soil and climate. In England, where sheep have been bred for a long period of time, different breeds have been evolved exactly suited to local conditions, and in the little territory of England there is a great variety of sheep, which have been developed to suit the exact conditions of each locality; from the Moorelands, with their Romney type, to the Cheviots in the Scotch Highlands, and the Kerry sheep for the rough mountain sections of Ireland. It is worthy of note here to state that the British Isles esteem sheep husbandry as a most important part of agriculture, especially in connection with the maintenance of soil fertility on high-priced lands. And it is also worthy of note that the British Isles, with an area less

Soil Survey Should be Made of CutOver Lands 
Different

Types of

Sheep for

Different

Localities

Sheep as a Fertilizing Agent than the state of Texas, produces practically the same amount of wool, on a scoured basis, as we produce here in the immense territory covered by the United States. The Spanish merino has thriven on the green hills of Vermont; on the mountain ranges of Wyoming; on the pampas of the Argentine; on the veldts of Africa, and on the great plains of Australia. And the English type of sheep have thriven equally as well in the same regions. Given the land areas, therefore, which you have, and establishing their adaptability for the maintenance of sheep, it would seem quite reasonable that all that is necessary is an intelligent and scientific attention to establish in this Southern territory a vast industry, which will lay the foundation for a better agriculture and a diversification of agricultural production, which would be of such great advantage to the Southland.

I have touched upon sheep husbandry mainly in connection with its meat and wool product, but there is another consideration, which I wish to emphasize, and that is, that the sheep is known to be one of the best fertilizing agents of any kind of live stock. This has long been generally recognized by shepherds, and their appreciation of this fact has been shown by their use of the term "The Golden Hoof," as applying to this feature of sheep husbandry in its relation to the fertility of the soil.

I have presented to you this matter of the sheep industry entirely from the commercial standpoint. I am going to take the liberty to suggest to you that under the circumstances this matter is worthy of your consideration from another point of view than pure commercialism.

No one is justified in allowing that which may be made productive to stand idle. It seems to me there is a moral obligation that rests upon people like yourselves, who control great quantities of lands, to make those lands productive for the national needs. Your opportunities in all things are created for you by the activities of the millions of people in these United States. There is a mutual interdependence, at times intangible but alvays real, between each individual and each community in the nation. Today and in the future the cry of these other millions comes to you, to use your land to supply their needs. 


\section{Forestry and Cattle Raising on the Cut-Over Pine Lands of the Southern States By Major J. G. Lee}

Department of Forestry and Horticulture, Louisiana State University

Mr. Chairman, Ladies and Gentlemen of the Conference: I want to preface what I shall have to say by stating at the outset that my remarks will apply only to the long leaf pine flats and hills of the cut-over pine region and not to the short leaf pine and mixed hardwoods appearing just north of the long leaf pine growth. These latter soils, having a good red clay subsoil, are better grade of the sandy loam type, and are better suited to agriculture. And in the short time allotted me to discuss so big a subject as forestry and cattle raising on the cutover pine lands of the South. I can speak only in general terms, and discuss general principles, the fundamentals, if you will, which ought to govern policy and procedure in any plan which might be devised for their economic development.

First of all, I want to make a plea for forestry and reforestation upon much of this cut-over land. The forest resources of the South and the industries dependent upon forests, the continuity of growth and use, are too important, they are too The Necessity of Reforestabig an asset to state and nation, now and always, not to be given serious consideration and provision made for their perpetuation and preservation.

According to Chief Forester Graves, more than one-fifth of the nation's total timber wealth is found in the South. About one-sixth of all the soft woods of the entire country and over one-half of the hardwoods are in the South. Our great naval stores supplies, upon which many of our important industries depend, are in Southern pineries. With the exhaustion of these and of our hardwood supplies comes also the exhaustion of these and other industries, which will materially and vitally affect the whole country. 
And yet we are told that nowhere in the United States can the naval stores industry or the production of hardwood timber be carried on with the same natural and economic advantages as in the South. Mr. Graves says further that Southern pine is the principal softwood used in fully two-thirds of the country east of the 100th meridian, or that portion comprising 70 per cent of the country's population. Backed by a supply of some 325 billion feet of yellow pine and about 20,000 sawmills. the pine industry holds today a commanding place in thę nation's lumber market.

The existence of this vast storehouse of lumber has played a great part in the development of the South and has been the source of a great deal of wealth. Today the forest industry stands first in no less than six Southern states, second in an-

Southern

Forests as a Wealth

Producer

France's ArtificiallyDeveloped Turpentine Industry other four, and third in another three. A half billion dollars is invested in this great industry; more than 400,000 people are employed in it : 20,000 sawmills and other manufacturing establishments are supported by this great industry. The forest industry draws upon a resource occupying now more than half the total land area of the South. By their very magnitude the forest problems of the South command attention. Their local importance, looking to the future, is so great that no consideration of the welfare of the South can afford to omit them.

With this authoritative view of the situation, so well and so forcefully stated, may we not pause in our deliberations and consider further these forests and their place in the economic development of this vast region.

Up to date the turpentine industry, a by-product of the forest, has had the advantage of a great natural forest, richly endowed with species capable of yielding an abundant supply of turpentine and rosin. The diligence of man has neither founded nor preserved the virgin supply. On the contrary, its destruction will be brought about by men unless steps are taken to prevent it.

There are but two great centers of turpentine supply, viz.: Southern France and the Southern United States. In France it is a "man-made" industry. We are-told that "out of shifting. barren sand dunes and a malarial, poverty-stricken region" the French government, through reclamation and the planting of maritime pines, has made one of the most prosperous and salu- 
brious sections of France. A century ago these lands had no value. It is said that " $\$ 1.00$ would buy land, in extent, as far as the voice would carry." Yet today this reclaimed land is worth from $\$ 2.50$ to $\$ 25.60$ per acre. The forest pine land stocked with 2 -year-old pine seedlings is worth $\$ 9.00$ per acre; stocked with 10 -year-old pine it is worth $\$ 30.00$; stocked with 30 -year-old pine it is worth $\$ 80.00$, and with 50 -year-old pine it is worth $\$ 160.00$ per acre.

Is this sort of development not worth while and may we not heed the lesson and plan for its application in much of the region we are now considering, as part of a forest policy yet to be adopted?

Again, a hitherto unutilized resource of waste material in manufacture, another by-product, has come to Southern pine and it has come to stay, if provision be now made for future supplies. I refer to the paper pulp industry, now so acute in this country. The Great Southern Lumber Company at Bogalusa has already learned this wonderful economic lesson of closer utilization of waste material for paper pulp, and it is demonstrating it to the world. The ultimate exhaustion of virgin supply and the problem of future supply is even now receiving the attention of Mr. Sullivan, the manager, and experiments in growing native pines to meet the situation are under way; and it would appear that our native loblolly or old field pine, less resinous, hardy, quick growing and persistent, might prove itself adequate, and it is indigenous to all the region under consideration.

However, our forest problem here is not one merely of lumber, trees, turpentine, and paper pulp. "There is involved the principle of the productive use and occupancy of the land, whether it be in agricultural home building or the growing of trees." And in its further consideration I want to lay down as a fundamental proposition that forestry, like agriculture, is a land problem, an economic problem, an educational problem.

Foresters everywhere recognize and practice these principles, viz.: First, that all land should be utilized; second, that land should be put to its best and most economic use; third, that all land fit for agriculture shall be devoted to, or reserved for, agriculture; and fourth, that all land not fit for agriculture Forestry as an Asset to Agriculture shall be devoted to some kind of forest growth, for let it be re- 
membered that there are no soil conditions, rich or poor, high or low, wet or dry, but they will grow some sort of trees useful to mankind. Agriculture is our great basic industry, but next to it is the great business of forestry and its dependent industries.

Three centuries of agricultural history in this country has given us a clear definition of agriculture and its many phases of stock raising, dairying, marketing, etc. Likewise has three centuries of forestry in Europe given equally as broad a definition for forestry and its dependent industries. There both forestry and agriculture are considered as land problems and forestry is co-ordinate with agriculture. Likewise must we also come to consider broadly forestry with agriculture in the solution of our land problems-hand in hand they must go: both are products of the soil, one an annual, the other a periodic crop.

In German states, where conditions are not so favorable for forest growth as they are with us, forest lands are made to pay

Where Forest Growth Has Been Made Profitable from $\$ 2.00$ to $\$ 7.00$ per acre per annum, with all the land devoted either to agriculture or to forests. Now, assuming Louisiana to be representative of the Southern cut-over pine lands, and that soil and other conditions are not very dissimilar, let me consider more directly the problem of their development and the principles of action that should guide in the solution.

According to the State Conservation Commission, there are five and one-half million acres of cut-over pine lands in Louisiana alone, and I.understand some $8,000,000$ acres of such land is owned by members of the Southern Pine Association. There are other millions not credited, aggregating a total of $76,000,000$ acres. These are waste lands, producing nothing other than taxes, yielding no revenue, paying no interest on invested capital. They are idle lands and should be put to some sort of use. Shall they find their best use in timber production or in some form of agricultural production?

Undoubtedly a large percentage, 75 or 80 per cent, is fit for some sort of farming. The remaining 20 or 25 per cent is certainly fit only for some kind of forest growth. Moreover, with the most favorable colonization schemes in operation, it will be a generation or more before all the agricultural lands will be occupied, and in the meantime why should they not be growing timber? 
Much of the land of the long leaf pine region now under cultivation had best be in forest growth, and likewise much in forest might best be in agriculture.

Therefore, might it not be a wiser and better plan to recognize and follow the principle of practice laid down by European states and by our National Forest Service, viz.: by an authoritative soil survey and an intelligent land classification program, whether they are absolute forest lands or absolute agricultural lands, thus to determine these facts of land use? By this competent means we shall then have definite knowledge to guide. as to lands, their best use, crops, kinds, adaptability, etc. Then and not till then shall we be able to determine intelligently and definitely the truth about them and their development, whether in forest or in agriculture.

Any other speculative scheme for colonization might, as it has done in the past, prove disappointing if not disastrous, and the results return to harass the inventor and injure the state permanently. For in their agricultural exploitation let it not be expected that so utilized they will be the "cure-all" for present agricultural ills and shortages. It is not true, and though the heavens fall, let the truth about them be known and told.

Primarily the long leaf pine grows on poor soils. These cutover pine lands generally are poor lands and we must recognize that fact. Unaided, we must not expect profitable production of staple crops. However, they are of varying character, and, by selection, many acres may be found that are susceptible of improvement and responsive to intelligent fertilization. With the proper rotation of crops, using cow peas and other legumes in the rotation, supplementing with liberal applications of commercial, home-made, green and other manures, and with a good system of drainage, particularly on the pine flats, they can be made profitable.

This is abundantly attested by the $\$ 3,000,000$ annual strawberry and vegetable crops produced on cut-over lands along the Illinois Central railroad in Taingipahoa Parish, and in the developing pecan and citrus fruit industries in the coast region of the Gulf states.

Again, on most of these soils, due to their sandy character, peanuts, sweet potatoes, cow peas, velvet and soja beans produce well, and their extensive growth and use on such lands will

Crops Best

Adapted to Cut-Over

Lands
Cut-Over
Lands Should
be Classified 
form the bases for their improvement, and for an ultimate profitable $\log$ and cattle raising industry, for these crops, in these soils, have the advantage over the heavier and more fertile soils.

On the other hand, it is equally true that the remaining 20 or 25 per cent of these cut-over lands is fit only for forest growth of some kind. This is particularly true of the dry sand ridges and hills found north of the pine flats of the coast region. Poverty, leaching and erosion of all such lands would be the problem and the remedy would be a forest growth of proper species.

Reforestation here should be our slogan; and yet before reforestation work shall appeal to the average owner the educational side of our problem must be emphasized. We shall not

Educating the Public on. Reforestation

Three Enemies to Forest Growth progress in reforestation until the state and the public are behind the work; and this will hardly come about until, through a slow process of education, we are brought to appreciate more fully its economic need and importance, and that it is essential to our industrial development and to the solution of this great idle land problem.

If forestry means anything it means reproduction, a continuity of forest growth and a continuity of forest use-a maximum of growth in a minimum of time, at a minimum of cost. secured through the best possible silvicultural system of management, the forest cut on a rotation basis, and cutting no more per annum than the annual growth.

Forest fires, after man, are the worst enemies of the forest. They prevent and destroy reproduction and otherwise injure and destroy standing timber. The practice of burning off the woods to improve grazing, so frequently done throughout the pine region, must be corrected, and the fact of injury done by fire to both soil and forest must be taught.

And, again, let it be taught that grazing by cattle, goats. sheep and hogs is permissible only in mature forests; that they have no place in a seedling forest. Within the past few years. in his reforestation work at Urania, Mr. Hardtner has found and proven that the "razorback" hog is even a worse enemy than fire to long leaf pine reproduction. And who will say that the razorback hog should have place in any modern agricultural community development!

This development problem is complex and in its solution thoughtful men and women everywhere must give it their sym- 
pathetic interest and co-operative effort and support. "In a multitude of counselors there is safety."

Much that I have said concerning agriculture in the cutover lands is applicable to the cattle raising part of my subject. But concerning cattle raising specifically, it is undoubtedly true that with the cattle tick eliminated, as it will be, a profitable cattle industry may be developed on much of our cut-over lands, particularly on the pine flat lands, though not. with the scrub type of cattle.

In determining the adaptability of a region for a profitable cattle industry, several conditions must be considered and provided for. An abundant supply of good water, ample pasturage for grazins. meadows for hay, good soil for the economic production of forage and ensilage crops, transportation, and a convenient cheap source of supply for concentrated foods-these are essential.

Within the region most of these conditions are met or may be met. It must be remembered, howerer, that the natural grazing is not first class. The native grasses growing in the pine woods do not have a high nutritive value. By the introduction of cultivated grasses, however, particularly lespedeza, carpet and Bermuda grasses, this difficulty may be overcome. Indeed, these grasses are already finding themselves distributed and thriving on many of the better types of pine flat soils. By soils preparation and selection, meadows of these same grasses may be developed and supplemented with peanut. cow pea. velvet and soja bean hay. According to Dr. Nesom of the Federal and State Live Stock Extension service it will require five to six acres of cut-over pine land summer grazing for the support of one cow. He also tells us that one acre of good Bermuda grass on our heavier, more fertile soils will support two head of cattle through the growing period.

The problem of cultivated forage and ensilage crops for winter feeding on cut-over lands is more difficult of solutionit involves the agricultural difficulties previously referred to. First of all, there is the problem and cost of stump removal to be considered and again the problem of drainage of the pine flats, embracing varying soil types of sand, silt, sand and clay loams, underlaid for the most part with a stiff impervious clayI repeat that here drainage is of the first importance.

Essentials to

Successful Cattle Raising
The Problem of Winter Feeding 
This condition met and the system of rotation and fertilization practiced as already mentioned, then the problem of forage and ensilage crops becomes easy.

According to Mr. Perkins of the Federal Live Stock Extension, soja beans and corn and sorghum are the ideal and economic ensilage crops for Louisiana. The cut-over lands unaided would hardly produce a profitable tonnage in corn, sorghum, or soja beans, say five to seven tons per acre, compared to ten to fourteen tons on the better lands of the state. This will about hold true with sorghum, cane and other forage and ensilage crops of the state. However, these yields with soil improvement may be approached if not equaled on much of the cut-over regions.

The conditions of climate, mild winters, ample rainfall, long growing seasons, etc., are splendidly met in all the cut-over pine regions of the South, and with these natural advantages in our

Climatic and Other Natural Advantages favor, why may we not remove the minor difficulties and build up a profitable cattle and hog industry throughout the cut-over pine regions of the South? The Morris packing plant to be built in this city even now calls for such an industry. And history teaches that without a live stock industry no system of agriculture can become permanently profitable, for "live stock is the strong right arm of agriculture."

Briefly and in conclusion, Mr. Chairman, the ideal of economic development, which I would love to see come to these $76,000,000$ acres of idle cut-over lands, if practicable, is something like this:

First-Survey and classify as indicated, ascertaining by experimentation their best economic use, forest or agriculture, and so locate and designate them as definite information. This would separate all lands into two general classes, viz.: absolute forest lands and absolute agricultural lands. The agricultural land might be further classified then as to the kind of crops it were best to grow. The absolute forest land then to be reforested with the best suited, most needed, rapid growing species. and so kept scientifically and permanently in forest supply.

Second-Colonize, selling in small farms to bona fide, thrifty farmers-home and agricultural community builders-at a price, based upon productive value, with enough of the forest land 
added, the "farm wood lot," to amply supply domestic needs and local demands for cord wood, posts, poles, cross-ties, and some dimension stuff, and so managed as to satisfy the principle of continuity of growth and continuity of use. In such a colonization plan, selfish speculative schemes should have no part, and if faithfully carried out would ultimately occupy and utilize all the land economically. It would settle the region with communities of small white farmers, owning and operating intelligently, scientifically and intensively their own farms, building good roads, schools and churches; producing wealth for home and state, through a sane and profitable system of diversified agriculture, of crops and animals-making "two blades of grass to grow where none grew before." 


\section{The Necessity for Organized Effort}

\section{By General L. C. Boyle of Kansas City}

Mr. Chairman and Gentlemen: I want to tell you of a thought that has occurred to me while I sat here today listening to this discussion. You talked about sheep, important as it is; cattle and hogs and grain; but there is something at the base of all that which is more important than anything else, and that is that this Conference is giving evidence of the right spirit, the unselfish spirit; that is an evidence of devotion at a very logical and critical time in our nation's history.

What is this movement we are discussing here? It is a movement that, at its base, means, Back to the land. My friends, we are 140-odd years old, this nation. Jefferson said we should have a government here devoted to agriculture. $\mathrm{He}$ discouraged industry, in our modern sense of great industrial

The Nation's Trend Away from the Farm
Rural Depopulation a Menace to the Nation centers; discouraged the commerce of the seas, and said that we should have a great nation of agriculturists, with small communities. That was the ideal social body, according to the vision of that great far-seeing man. For a little while, however, and for years, we were an agricultural body; but in the last thirty-six years the trend of oscillation has been from the farm to the great cities of the land. Thirty-odd years ago 70 per cent of our people lived on the land or in rural communities. Today over 50 per cent of our people live within city walls. From a producing, we are becoming a consuming nation. From a rural we become an urban social order.

The history of the peoples of the past, as written, teaches their love of the land and their loyalty to the land; and just in proportion as they left the land for the cities, in that proportion can you read the downfalls of the nations of the past. The observers and thinkers of modern life here in America recognize a menace to the national life in the growth of our great cities and the depopulation of our rural communities. Do you know 
that Iowa, that Missouri, that Illinois, that the great central agricultural part of this great nation has lost population in its rural life in the last ten years? The cities have grown apace, but the farms are gradually being deserted. We are becoming a purchasing nation, teaching food values in the raw material. This is not as it should be; and the deep significance to me of this movement here-the broad basis that is at the base of itis that you are teaching the youth of the land here in the South that the prime necessity of the hour is, Back to the soil.

My friends, we are living in the most classic period in the world's history. We read the history of Rome and the peoples of the past, and our own early strife and struggles; but at no period of the world's history were there such great things at stake as right now; and this great nation is to be a pathfinder in this new order of things. (Applause.) She was the harbinger, and we led the battle, for freedom originally. Her example has inspired the hearts of the people of Europe. Today we see China and Russia and movements in other countries evidencing the desire for freedom. We have gone into this great conflict, not with the desire of conquest, but that democracy may be the ruling principle of the world. (Applause.) Democracy-that is the spirit abroad in the world today. It is the great contest that is being fought on the bloody fields of Europe; and here in the South, in the presence of you fine men and women, I want to say that you are doing a great patriotic duty and helping this cause of freedom by urging the cultivation of the soil, that our people may be fed, and that we may feed the soldiers who are fighting your battles, and your children's battles. That is the significance of this great meeting here. It is the spiritual thing involved here. Why, sir, to me it is an exalting thought that you haven't heard a man today talk about profit; not a man today has been talking about how much money he could make; everything has been in the spirit of helping the little fellow-of doing something for the state and the nation. And, my friends, is it not something to be proud of that we have that spirit? Why, it is the spirit that was in us when we defeated Spain and took the Philippines from her, and then paid her for them. It is the spirit that animated us when we went to Porto Rico and built roads and gave her schools and an efficient government; when we went to Hawaii and gave her order and industrial prosperity. It is the spirit that makes us want to help construct and

Inselfish Co-operation Spirit of the Conference
America as the Pathfinder of the World's Democracy 
aid, and not tear down, and that is the spirit here. The thing we are in this war for is to aid and construct, and that is the spirit here; to aid the little man to come and get this good land of yours in the South that has been lying here. It is a fine thing to see men like Mr. Bigelow come from Philadelphia; like this other man from Michigan, and others from a distance, to come down and talk to you, not for money, but to help you and themselves and the nation; and that is the big thing of this meeting. There is nothing selfish about it, nothing ordinary about it, nothing sordid about it. I also see manifested here the spirit of co-operation. That is the cornerstone of social life. The church and school are the great distributors of the co-operative spirit. Everything must be co-operative. No man is sufficient unto himself any more. The day of individualism is past. The day of the man working alone at his task is past. The railroads and the telegraph have made us co-operate. We cannot live within ourselves; we must live for and with each other; and it is only through co-operation that this great enterprise can truly be made a success.

Interesting as it is, we may observe the practical illustration of that, in this question of pulling up stumps. The poor man cannot buy the machinery sufficient to do this work himself; but a group, co-operating, can. A man cannot by himself eradicate the tick; but groups of them can, by co-operating with the state. The subject of the hour is co-operation. Here we find the nation sending its skilled scientists down here to talk to the farmer. Do you know the new thought coming to those people and to the nation? It is not government ownership-but gov-

Cut-Over Land Owners Must Get Together ernment co-operation with the people; that is the order of the day. (Applause.) Why, it took us 105 years to realize the necessity of a Department of Agriculture in this nation of ours. Although an agricultural people, we lived as a nation for over a hundred years before they gave you a Department of Agriculture. One hundred and twenty-five years passed before they saw the necessity of giving us a Department of Commerce; and but a few years ago-three, in fact-we developed the Department of Labor. Gentlemen, this has been a slow growth, but the nation is getting hold of itself and is understanding the problem of government. Government is nothing more than you and $I$ and each of us trying to help each other; and having men up there in Washington making studies and scientific research, 
working splendidly there to aid all of us. Here we have the banks getting together and co-operating through the Federal Reserve Bank. Here we have the railroads co-operating through the Interstate Commerce Commission, or we have the farmers co-operating through the Agricultural Department. Everything has the spirit of co-operation, and here you are getting it down here, teaching us about these good lands that may be made so useful by co-operation. No lumberman, no owner of cut-over lands, can do anything by himself; but with his neighbor and that spread out through all the state, much can be done.

It is a pleasure to have been here. I want to say to you that the great vital thought I will carry away is this: The men who had the vision, the understanding and the spirit to conceive this thought, and then work it out in a masterful way, and make manifest their purposes so clearly; who have had a nation's agriculturists and scientists, business men and lawyers, attracted to the big idea they evolved-that is the big thing here; and men that have that conception, and that can state it so clearly as to challenge our admiration, are bound to succeed in this great enterprise. I have no doubt that you men are not the kind of patriots who just appear and make a noise, but you are the kind of patriots who will persevere in this great task of making these lands that God gave the people habitable for the poor and the needy, and again restore this nation to a self-sufficient, self-supporting, prosperous, glorious country that will be the leader of your democracy for all time-if we are but true to our opportunity. I thank you. (Applause.) 


\section{Cut-Over Lands and Their Value}

By C. C. Prescott

\section{Agricultural Agent, Southern Railway System Development Service}

Make Lands Attractive to Prospective Settlers

Drainage and Stump Removal

I was raised on a South Mississippi farm on pine knots and clabber. This was a cut-over land farm and produced crops every year. Any cut-over farm land in the pine belt can be made to do the same thing.

There must be certain essentials for the development of this land in order that it may yield the maximum crops for the labor expended. Naturally, of course. on cut-over lands the appearance has a great deal to do with newcomers or buyers living near them. These lands after the timber has been cut off are left in a dilapidated condition.

In order to facilitate matters in so far as reclaiming these lands from an agricultural viewpoint, the stumps, tree tops and gullied lands should receive attention at the earliest possible moment. In other words, cut-over lands should be made productive. Thousands of acres of this land should now be in cultivation producing food and feed crops and at the same time giving homes to thousands of people who need these lands.

Today the large land holder is detrimental to the agricultural progress of any territory. He should be induced to cut this land into smaller area, and aid in building communities and good roads in order that it will appeal to the man who has brains and money and is seeking a home. Our cut-over lands will remain idle for years to come unless our business enterprises and large land holders put forth every effort to make these lands attractive.

As they are, thousands of acres look like a gigantic army en route for Germany on account of the millions of stumps. These stumps should be converted into charcoal and smoke, thereby eliminating a great drawback to our agricultural progress. 
Thousands of acres of this land should receive attention with reference to drainage. This will cause a greater production of crops and this matter can be handled with the manufacturers of drain tile. Thousands of acres of this land could be converted into dairy farms and beef cattle ranches under competent management.

I believe a lot of people are looking for such opportunities if these lands can only be shown in an attractive way. Therefore, my solution for the situation is that every large land owner, especially the lumber interests, should put forth every effort to put all cut-over lands in attractive shape, sell these lands at a reasonable price for cash or on terms to suit a worthy prospect. 


\section{Resolutions Adopted at the Cut-Over Land Confer- ence of the South}

Resolved, by the Cut-Over Land Conference of the South representing Eastern Texas, Arkansas, Southern Missouri, Mississippi, Louisiana, Alabama, Western Georgia and Western Florida, in convention, assembled at New Orleans, La., April 11th, 12th and 13th, 1917, that:

WhEREAS, in the present national crisis the production of food, especially of meat and dairy products, is of equal importance to the manufacture of munitions of war; the success of the United States and her allies in the great war will largely depend on the maintenance and increase of the supplies of food-producing animals in the United States; the largest area of undeveloped but potentially valuable cattle-producing territory in the country is situated in the Southern states and the greatest obstacle to the extension of the cattle industry of the South is the Texas fever cattle tick;

Eradication of the Cattle Tick

Therefore, Be It Resolved, that the rapid, efficient and complete eradication of the Texas fever cattle tick has now become a patriotic obligation upon those states comprising within their borders areas still under quarantine; and

Be It Further Resolved, that this Conference urge upon the legislatures of those states which have not already done so, to pass without delay state-wide tick eradication laws, and that the Government of the United States, if necessary as a war measure, exercise the power vested in the Secretary of Agriculture of the United States by act of Congress to facilitate the complete eradication of the Texas fever cattle tick within one year.

Be It Further Resolved, that a copy of this resolution be forwarded to the President of the United States, the Congress of the United States, the Secretary of Agriculture of the United States, and the Governors of the states of Texas, Arkansas, Mississippi, Louisiana, Alabama, Georgia and Florida, with the urgent request that these resolutions be given most serious consideration. 
Resolved, by the Cut-Over Land Conference of the South representing Eastern Texas, Arkansas, Southern Missouri, Mississippi, Louisiana, Alabama, Western Georgia and Western Florida, in convention assembled at New Orleans, La., April 11th, 12th and 13th, 1917, that:

Whereas, it is of vital importance to the American people that they be assured of an adequate supply of food products and of raw materials to meet the growing population and our expanding industries; and,

WhEREAS, the public domain of the United States adaptable to present day remunerative economic use is substantially exhausted or shortly will be; and,

WhEREAS, the vast areas resulting from timber operations in the states above mentioned because of their proximity to our great consuming centers, and to our export ports, are worthy of immediate serious attention with respect to a present beneficial use, and ultimate settlement and development; and,

WHEREAs, practically all efforts at so-called colonization have in large measure been more or less unsuccessful and not lasting and permanent, and because of their too intensely commercial aspect have largely resulted in a loss of public confidence, and have often brought the promoters into national disrepute; and,

WhEREAS, the problem is one of practically national importance and should command the assistance, support and the best thought of all agencies; now,

Therefore, Be It Resolved, that the chair be and is hereby instructed to appoint a committee to consist of ten members who are subscribers to the Southern Pine Association, of which the chairman hereof shall be one, which committee may associate with themselves, if their judgment so warrants, representatives of any other agencies interested in the development of the South, and which committee shall as soon as practicable provide for an organization and the financing thereof, together with a concrete plan of operation of such organization, the same to be known and designated as the Southern Cut-Over Land Association.

Be It Further Resolved, that said committee be empowered to either incorporate said association or organize the same as a voluntary organization, and to provide for its independent existence, or to effect mergers with other and similar movements, as their best Appointment of Organization Committee

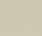


Be It Further Resolved, that the owners of the idle, unused and unproductive lands in the states mentioned are urged to support the association hereinbefore provided for, to the extent of a levy not to exceed one cent per acre per year, for such period of time as it shall be determined shall comprise a period necessary to effect comprehensive development; and,

Be It Further Resolved, that such land owners in the area designated are urged to immediately adopt, wherever practicable and feasible, some form of live stock industry, not only as a part of the general plan of development, but also in response to the nation's need in view of the present national crisis; and,

Be It Further Resolved, that said committee in working out a concrete plan shall take into consideration cattle tick eradication, water control, standardization of land sales, legislation with respect to land titles, land classification, and in particular a campaign of general publicity, and such other activities as may be deemed proper and conducive to the successful operation of such association.

Be It Further Resolved, that inasmuch as many acres of this area are better adapted for forest growth than for agricultural crops, that the association shall undertake to further and promote the development of approved forestry methods, looking toward reforestation of such areas, for the benefit of future generations, and where practicable to combine such reforestation methods with live stock development.

Be It Further Resolved, that a rising vote of thanks be tendered all officials and representatives of the Federal Government participating in the program and in the discussion at the Confernece; also to all representatives of state agricultural and other in-

Federal

Officials

Thanked for Co-operation stitutions participating in the program and the discussions at the Conference; also to the press of the entire country for its co-operation in disseminating news of the Conference; also to the railroads for their co-operation in naming reduced round trip railroad fares, and to the representatives thereof present and participating in the discussion; and to all others not specifically enumerated herein who have lent their advice and aid to the Conference in accomplishing the constructive work toward which the Conference is aiming.

Resolved, by the Cut-Over Land Conference of the South representing Eastern Texas, Arkansas, Southern Missouri, Mississippi, Louisiana, Alabama, Western Georgia and Western Florida, in con- 
vention assembled at New Orleans, La., April 11th, 12th and 13th, 1917, that:

WHEREAS, ready markets for live stock produced on cut-over pine lands of the South are as essential as the production thereof;

Now, Therefore, Be It Resolved, that this convention welcomes the advent of Morris \& Company with their New Orleans packing house as a distinct encouragement to a present beneficial use of cutover pine lands for the raising of cattle.

Resolved, by the Cut-Over Land Conference of the South representing Eastern Texas, Arkansas, Southern Missouri, Mississippi, Louisiana, Alabama, Western Georgia and Western Florida, in convention assembled at New Orleans, La., April 11th, 12th and 13th, 1917, that:

Whereas, it is necessary for the National Government to raise a very large amount of revenue to meet the extraordinary expense of war; and,

Whereas, it is estimated that there are kept in the United States about $25,000,000$ dogs, which are not only a luxury, and therefore properly subject to taxation, but which are also a cause of much damage to all kinds of live stock;

Therefore Be It Resolved, That we urge upon the Congress of the United States to enact a law placing a per capita tax of $\$ 1.00$ on all dogs as a wise financial and economic measure; and

Federal Dog Tax Recommended

Resolved Further, That a copy of these resolutions be transmitted to our Representatives and Senators in the Congress with the request that they take prompt action to enact a law levying a Federal Tax on all dogs.

As men, proud of the fact that we are citizens of the United States of America, realizing as we do that our country is about to be called upon to meet heretofore unheard of demands, fully imbued with the spirit of patriotism and a desire to co-operate to the fullest extent with our President in whom we have devoted confidence; be Lumbermen Pledge Holdings for Use of Nation it therefore

Resolved, That we, the representative owners of the vast area of Southern cut-over lands, do hereby pledge to our President these holdings, that he in his wisdom may direct their use for the benefit, the betterment and the furtherance of humanity in accordance with his plans, in all of which we are in hearty accord. 


\section{Senator RansdellSendsGreet- ings to Conference}

Washington, D. C., April 11, 1917.

Cut-Over Land Conference of the South,

New Orleans, La.

I. deeply regret that imperative official business prevents me from attending the Cut-Over Land Conference of the South in your city today. The cut-over pine lands of the South constitute a vast domain susceptible of wonderful potentialities in agriculture and forestry, which should call for our very best efforts in constructive statesmanship.

I hope the Conference will form a permanent organization to handle these lands in a big way in connection with our various state officials and commercial bodies in our principal Southern cities.

We must demonstrate honestly and on a large scale for what purposes these lands are best adapted, whether reforestation with quick growing trees, or agriculture in its many forms, especially live stock.

Then we must invite immigration and settlement by honest advertising. We must tell the whole truth about our lands, and devise plans to protect prospective settlers from real estate sharks.

There is so much merit in these lands that we are bound to have great success in disposing of them if these methods are followed.

I pledge my loyal support to the good cause in every way possible.

(Signed) Jos. E. Ransdell. 


\section{List of Attendance Cut-Over Land Conference of the South}

NAME

\section{REPRESENTING}

ADDRESS

ALExANDER, M. L.......... Chairman, Louisiana State Conservation Commission....... New Orleans, La.

Allen, William, Mgr C. \& T. Bureau N. O. Assn. of Commerce............... New Orleans, La.

Aiken, Gayle, JR Chambers Agency Inc. Alexander, J. W. Insurance \& Farming. .New Orleans, La.

Agassis, G. Insurance \& Farming. Alexandria, La. Ayres, Walter S., Ind. Com.

.New Orleans, La. Alberts, Ernst. Washley Farm \& Dev. Co.... New Orleans, La.

BEHRMAN, MARTIN, Mayor.

New Orleans, La.

Bruguieres, Jules M.

Beston, D. P.

Atty. at Law. .

W. Palm Beach, Fla.

Bondurant, J. R.

Agriculture \& Oil. .

Mobile, Ala.

Brumfield, O. N., Mgr........ Illinois Cent. R. R. Co.........

Bigelow, A. C., Pres........... Phila. Wool \& Textile Assn...

Bateman, J. B., Jr., S. A....... Great Southern Lbr. Co.......

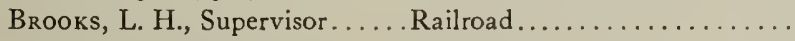

Bollinger, M. S., Vice-Pres..... S. H. Bolinger Lbr. Co........

Bridgewater, S., Gen. Mgr. . . Trinity County Lbr. Co..

Bloomer, P. A., Gen. Mgr...... Louisiana L. L. Lbr. Co. . .

EI Paso, Tex.

Jackson, Miss.

Philadelphia, $\mathrm{Pa}$.

New Orleans, La.

New Orleans, La.

Shreveport, La.

Bolinger, S. H., Treas. .

..S. H. Bolinger Lbr. Co..

Groveton, Tex.

Bruce, Geo. S., Im. Agt.

. International \& G. N. Ry .

Fisher, La.

Bonner, J. S., Pres.

Byers, W. C., Agri. Agt........ New York Central Lines. . . . . Chicago, Ill.

Bonner Lumber Co..........

. Shreveport, La.

Houston, Tex.

Bronson, J. W., S. Rep......... Kalamazoo Silo Co......... Thibodaux, La.

BaLIs, W. H. ..............Pig Club Agent La ......... Baton Rouge, La.

Beckner, S., Pres............ Bryceland Lbr. Co....... \{ Bryceland, La., and

Becknen, Okla.

Bolton, H., H., Im. Agt. . . . . Gulf, Mobile \& Newton R. R. . Mobile, Ala.

Bryant, E. S., For. Insp.......U. S. Forest Service..........Washington, D. C.

Brown, M. H., In. \& Im. Agt... Southern Railway. . . . . . . . . New Orleans, La.

Brown, E. W., Auditor......... Southern Pine Assn.......... New Orleans, La.

Brady, T., JR., Atty.......... Butterfield Lbr. Co.......... Brookhaven, Miss.

Barthel, R., Exporter........ Tropical Trading Co......... New Orleans, La.

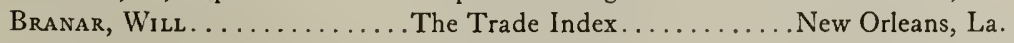

Brenan, T. E............. Insurance Business............. Orleans, La.

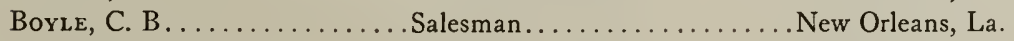

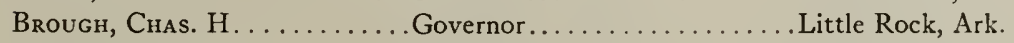

Black, Harry A...........Washly Farm \& Dev. Co..... New Orleans, La.

Billingsby, F. N........... Civil Engineer. ........... New Orleans, La. 


\section{NAME}

REPRESENTING

ADDRESS

Biegel, Geo. H.

Bowling, N., Com. Mer.

Real Estate \& Land Dealer. ... New Orleans, La.

Biery, Wm., Gen. Mgr...

Commission Merchant.

New Orleans, La.

Blakeslee, H. E., D.

. Pine Stump Product Co

Covington, La.

Boyle, L. C.

.Mississippi Cent. Expo.

Gulfport, Miss.

Bryant, R. C., Prof. of L'bring. . Yale University.

Kansas City, Mo.

Booker, Roy, Staff Cor......... Manufacturers' Record.

New Haven, Conn.

Baltimøre, Md.

CLAIR, J. C., Gen. Dev. Agt. . Illinois Central R. R...... . . Chicago, Ill.

Chappius, E. L

"Alluvial" Lands. . .

New Orleans, La.

Cern, Harry G., Secy. .

Thompson \& Tucker Lbr. Co. . Houston, Tex.

Courtney, G. A., Vice-Pres.... Southwest La. Farm \& Mlg. Co. Lake Charles, La.

Carpenter, Robt., Mgr....... Chicago Belt Mfg. Co........ New Orleans, La.

Clarkson, J. W., L. Agt. . .

La. Central Lbr. Co. . . . . . . Clarks, La.

Clayton, W. D.

.La. State Museum........... New Orleans, La.

Chapman, H. H., Dir.

American Forestry Assn....... New Haven, Conn.

Clark, G. S., V.-P. \& G. M. . . Tremont Lbr. Co............ Winnfield, La.

CAMP, H. A............. Lumber Mfr.............. Hattiesburg, Miss.

Chapman, B. F., Ch. Clk...... Texas State Dept. of Agr......Austin, Tex.

Conover, J. E. . . . . . . . . . . School Book Rep........... Little Rock, Ark.

Clappins, E. L., Jr......... Real Estate............. New Orleans, La.

Coles, R. N. . . . . . . . . . Com. Nursery Co..........Winchester, Tenn.

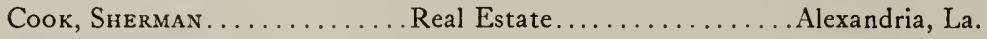

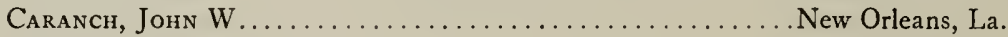

Cosron, J. T., Lawyer. . . . . . . . . . . . . . . . . Osceola, Ark.

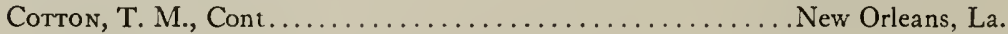

Cotton, J. E.............. Dept. of Agr ............ Covington, La.

Cuculler, Hy., Mgr...........Matthews Gravity Carriers.... New Orleans, La.

Cullom, E. T............. Lumber Mfr............. Springfield, La.

Curtis, D. R., Sou. Repr....... Dixie Portland Cement Co.....Chattanooga, Tenn .

DENECHAUD, J. F., Secy .... Immigration Dept. of La...... New Orleans, La.

DalRymple, W. H............ S. U................ Baton Rouge, La.

DeGrange, Jos. H., Secy....... Assn. of Commerce.......... New Orleans, La.

Downman, R. H., Pres......... Southern Cyp. Mfrs. Assn.... . New Orleans, La.

Doyle, Sarsfield ........... Fla. Farms \& Homes Inc...... New York City.

Dunham, F. V., Mgr...........Pav. Dept. Sou. Pine Assn.... New Orleans, La.

Davis, T. B., Pres........... Tallahola Lbr. Co. .......... Hammond, La.

Dodson, W. R., Dean.......... Agri. College of La . ........ Baton Rouge, La.

Derbes, Edw. J............. Stauffer-Eshleman \& Co....... New Orleans, La.

DenneE, John S........... Field Statistician Bureau of

Crop Estimates. .......... New Orleans, La.

Dixon, A. L., Mgr........... Gulf Motor Truck Co........ New Orleans, La.

Dinkins, L. N., Pres........... Interstate Trust \& B. Co...... New Orleans, La.

ENOCHS, F. B . . . . . . . . . . Farming Lumberman \& R. R. .Fernwood, Miss.

Elfert, M. T............. Timber \& Lands............ New Orleans, La.

Erchling, C. W . . . . . . . . Nurseryman.............. New Orleans, La.

Emerson, F. V................. State University........ Baton Rouge, La. 
NAME
REPRESENTING

Erichson, L. F .

EBENSBERger, H

Dixie Nursery Co.

Evans, J. A., Asst. Chief. . . . . Extension Wn. Sou. U. S. N. G..Washington, D. C.

Eiseman, Mayer.

Real Estate................ New Orleans, La.

ENDERLE, EdWARD

Lands \& Timber.

... New Orleans, La.

FARLEY, F. W

Fowler, R. B., Gen. Mgr.

U. S. Dept. of Agriculture.

Tremont \& Gulf Ry.

FERRIs, E. B

Ex. Stat. Director.

FERry, W. J., Pres

. Ferry-Hanly Adver. Agcy. .

Real Estate

Gulf Lbr. Co.

Southern Pacific S. S. Co

Fullerton, R. IW

Pennsylvania R. R.

Washley Farm \& Dev.

State Forester of Texas

Southern Pacific Lines.

Gulf Coast Dev. League.

Cotton State Lumber Co. .

G. L. \& N. Ry.......

Ga. State Col. of Agri..

Climax Lbr. Co.

Eastman-Gardiner \& Co. .

Shreveport Cham. of Com

Southern Pine Lbr. Co...

Gilbert, L. D

Home Builders Realty Co

Mississippi Lbr. Co.

Columbus Lbr. Co.

Green, A. E., Vice-Pres.

GLYNN, H. C

Gray, Mat., Correspondent...... American Lumberman. .

Griffing, W. D., Pres.......... C. M. Griffing \& Co.

Guild, W. E., Treas. \& G. M. . Finkbine Lbr. Co

Gilmore, A. B., Mgr.-Ed....... Modern Farming.

Tremont Lbr. Co.

Natl. Assn. of Box Mfrs.

Bay Minette Land Co.

Assn. of Commerce
Nona Mills Co....

Jackson, Miss.

Winnfield, La.

McNeill, Miss.

Kansas City, Mo.

Lake Charles, La.

E. St. Louis, Ill.

New Orleans, La.

New Orleans, La.

Lorraine, La.

New Orleans, La.

Mobile, Ala.

Groveton, Tex.

Athens, Ga.

St. Landry, La.

Laurel, Miss.

Shreveport, La.

Texarkana, Tex.

New Orleans, La.

Quitman, Miss.

Columbus, Miss.

Quitman, Miss.

. New Orleans, La.

Macclenny, Fla.

Wiggins, Miss.

New Orleans, La.

Winnfield, La.

Chicago, Ill.

Bay Minette, Ala.

. New Orleans, La.

Beaumont, Tex.
College Station, Tex.

Meehan Jct., Miss.

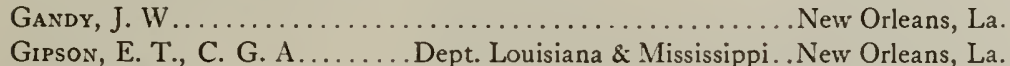

Goreau, W............... Go Ro Mfg. Co........... New Orleans, La.

Gheen, Russell T., Mgr. Trade

Extension Department. . . . . Southern Pine Assn.......... New Orleans, La.

GillisPi, J. O............ Atty. at Law............ Gulfport, Miss.

HULL, N. P., Pres............ National Dairy Union. . .

Lansing, Mich.

Howell, Chas. F.

Physician. .

Kinder, La.

Hattiesburg, Miss.

Haynen, Wm. J., Gen. Mgr..... J. J. Newman Lbr. Co. . . . . . Hattiesburg, Miss. 
ADDRESS

Hinton, R. W., Pres........... Hinton Bros. Lbr. Co. ....... Lumberton, Miss. Hallowell, R. M., Pres....... Industrial Lbr. Co........... Elizabeth, La. Helm, H. B., Vice-Pres......... La. Ry. \& Nav. Co. . . . . . . . Shreveport, La. Hopkins, S. G., D. P. A........ Kansas City So. Ry. Co...... Texarkana, Tex. Hamilton, Geo. C............ Freeman-Smith Lbr. Co....... Millville, Ark. Heflin, W. T............. Sheriff Winn Parish......... Winnfield, La.

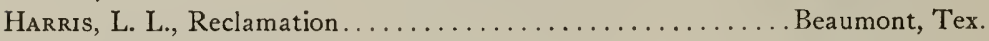
Harcop. B. T., Gen. Supt. . . . Tremont Lbr. Co...........Winnfield, La. Homeyer, H. C. ............ Land Dept., Hibernia Bk..... New Orleans, La. Henderson, W. L.,

In. \& Im. Agt. .............. Sou. Ry. System Dev. Ser . . . Mobile, Ala.

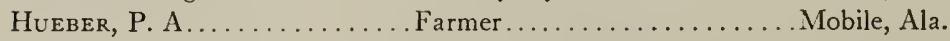

Heilbron, Louis, Rep....... Texarkana Chamber of Com... Texarkana, Ark. Hamilton, F. P. ............. Mississippi Planter......... New Orleans, La. Herriott, J. W. ........... Real Estate.............. Chicago, Ill.

Hoenan, A. S., Mgr... . . . . Pelican Box Factory......... New Orleans, La. Hero, Gus A., Pres........... Jefferson Plaquemine D. D. . . New Orleans, La. Houlton, W. L. ............. Houlton Lbr. Co. ......... Houltonville, La. Houlton, C. H.............. Houlton Lbr. Co. .......... Houltonville, La. Harper, G. B., A. G. D. A. .... I. C. R. R.............. Memphis, Tenn. Hewes, H. B., V. P. \& Treas... Jeanerette Lbr. \& Shgl. Co... Jeanerette, La.

\section{JAHNCKE, ERNEST LEE,}

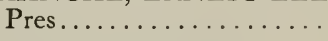

Jones, J. E., Chief Insp. Johnson, J. J., Supt.

Jansen, Chas.

JUdd, EdWARd S.

Jones, W. H... JoHnson, L. W. Jewett, B. N., Mgr. Jennings, T. A., Pres JAcKson, H. K.
New Orleans Assn. Commerce. . New Orleans, La. Southern Pine Assn.......... New Orleans, La. Cut-Over Land Dept., Great

Sou. Lbr. Co............. Bogalusa, La.

.Postmaster \& Gen. Ins. Agt... New Orleans, La. ................................... Ill.

. Dierks Lbr. \& Coal Co........ Kansas City, Mo. Wire \& Iron Bureau. . . . . . . . New Orleans, La. .N. O. Nelson \& Co. ........... New Orleans, La. Jennings Naval Stores Co..... Pensacola, Fla. Electric Lights..............Mobile, Ala.

KING, L. G., Auditor........ Tremont Lbr. Co...........Winnfield, La. Kelser, R. J., Bus. Mgr. . .... Trade Index.............. New Orleans, La. Klare, G. W............... Salesman, Reclaimed Land.... New Orleans, La.

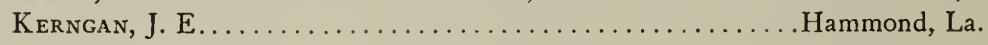

LEACH, N. M., G. T. Mgr.... Texas \& Pacific Ry......... New Orleans, La. Lovejoy, W. C., Receiver. ........ O. Netherlands Co........ New Orleans, La. LEE, A. J., S. P. A.......... Southern Ry............. New Orleans, La.

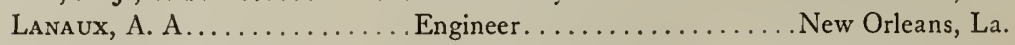
Law, G. W., Secy.-Mgr........ Lock-Moore Co., Ltd. . . . . . . Westlake, La.

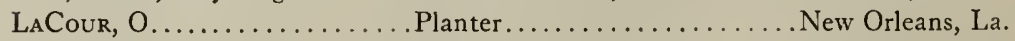
Livingston, Carl D......... University of Wisconsin....... Madison, Wis. LeE, S. P., Pres. ............ Lee Lbr. Co.............. Alexandria, La. LeEymard, E. P., Im. \& Agr. Agt................. T. \& P. R.R. New Orleans, La. 
NAME

REPRESENTING

ADDRESS

Lawler, Jvo., A. M. M...... Rapids Lbr. Co . . . . . . . . Woodworth, La. Learntt, R. A., Vice-Pres..... . Southern Land \& Timber Co... I adianapolis, Ind. Letts, Chas., Box Supt. ....... Eastman-Gardiner Lbr. Co. . . Laurel, Miss. LLOYD, E. R. . Director Miss. Expt. Station.... Agricultural College, Miss.

Ledoux, H. I., Secy........... Acme Home Assn ........... New Orleans, La. Lichtenstein, I. M., Del.......... O. Assn. of Commerce...... New Orleans, La. Loranger, H. R., Vice-Pres..... Genesee Lbr. Co............ Genesee, La.

LaGrone, J. M., Mgr.......... La. Creosoting Co...........Winnfield, La.

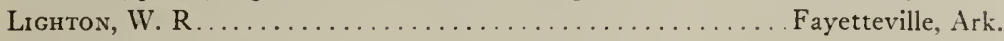

MARSHALL, F. R.,

Animal Husbandry

Bureau Animal Industry......Washington, D. C.

Mayo, H. M., Mgr. Ind. Dept. . Southern Pacific............. Houston, Tex.

Marbut, C. F................ S. Dept. of Agriculture.....Washington, D. C.

McLauchlan, Asso. Editor..... Lumber Trade Journal. ....... New Orleans, La.

Martin, W. A., Gen. Mgr.......American Lbr. Co........... Merryville, La.

Moreton, S. E.............. Lumber Mfr............ Brookhaven, Miss.

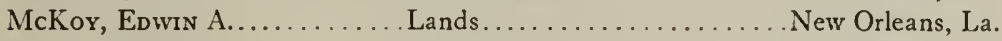

Mrles, L. T............... Salman Brick \& L. Co........ Slidell, La.

Moore, A. G. T., Asst. Secy.... Southern Pine Assn.......... New Orleans, La.

Mil.ler, R. G., Agr. Editor... . New Orleans Item.......... New Orleans, La.

Marshall, E. C. D., G. F. A. . L. R. \& N. Co . . . . . . . . . . Shreveport, La.

Mansfield, C. J., Vice-Pres.... Southern Lbr. Co...........W Warren, Ark.

Morse, Stanley F., Con. Agr.

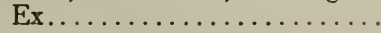

Morse, R. F., Gen. Mgr. .

Ludington Lbr. Co.

New Orleans, La.

Means, Guy R., Agr. Rep.

Dupont Powder Co

Ludington, La.

Morgan, Edw., Com. Ft. Agt...Baltimore \& Ohio R. R. Jackson, Miss.

.... New Orleans, La.

McGenee, F. C., Pres......... Pine Bluff Lbr. Co........... Pine Bluff, Ark.

Murphy, Jas. R., Pres......... Fla. Farms \& Houses, Inc.....Palatka, Fla.

MCDonnelL, L. T., Sou. \& S.

Mgr.

Bi-Lateral Fire Hose Co....... New Orleans, La.

McMahan, M. J., T. M........ N. O. G. N. R. R. Co........ New Orleans, La.

McCroary, S. H., Asst. Chief...U. S. Dept. of Agr..........Washington, D. C.

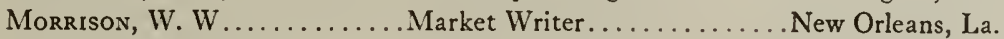

Murray, Kemball, Editor..... Real Estate Item........... New Orleans, La.

McIntYRe, W. G........... Forage Feeding................ Orleans, La.

McCreary, E. R........... Mercantile \& Saw Milling..... Bush, La.

Miller, Chas., Traf. Mgr......... O. N. \& N. Ry ...........Hammond, La.

Mrncy, S. S., Asst. Mgr........ Miss. Farms Co..........Wiggins, Miss.

NESOM, G. E., Supt......... . Live Stock Ex. Service. . . . . . Baton Rouge, La.

Nalty, W. H., V.-P. \& Mgr.....Hammond Lbr. Co. .........Hammond, La.

Nichols, E. A.............Wholesale Land Dealer....... New Orleans, La.

OTIS, J. S., Secy.............. Weston Lbr. Co......... . Logtown, Miss.

PIPER, C. V., Agrostologist....U. S. Dept. of Agr..........Washington, D. C.

Phillips, Henry............. Planter \& Land Owner......... Natchez, Miss., and

Ottumwa, Iowa. 
NAME
REPRESENTING

ADDRESS

Parker, Walter

Assn. of Commerce. .New Orleans, La.

Perkins, W. R. .

Forage Corp. Agent. Baton Rouge, La.

Palmer, L., Ex. Editor......... Lumber Trade Journal. . . . . . . New Orleans, La.

Pullen, King H., Dir. of News

Service................. Southern Pine Assn. . New Orleans, La.

Pedeaux, Ed. H., Mgr. Agr.

Dept.....................

Pipkin, L. B., Secy..............

Perrin, L. E., Dist. Agt........ U.

Putman, L. R., Adv. Mgr. . . . Southern Pine Assn.......... New Orleans, La.

Pullen, WM. H.

Stauffer-Eshleman \& Co....... New Orleans, La.

Pruden, Hy. B..

Insurance............... Jackson, Miss.

. . . . . . Covington, La.

Preston, E. V., Land Com..... Fernwood Lbr. Co............ Fernwood, Miss.

Power, C. W. . . . . . . . . . Furniture Retailer........... New Orleans, La.

Prescott, C. C., Agri. Agt. . . . Development Service.......... Chattanooga, Tenn.

Petribone, F. W............ Jordan River Lbr. Co........ Kiln, Miss.

QUERBES, ANDREW........ Chamber of Commerce....... Shreveport, La.

Querens, F., Jr............ Accountant................. Orleans, La.

ROMMEL, GEO. M., Chief Ani-

mal Husbandry Div..........

RenNyson, I. B.

U. S. Bureau of Animal Ind...Washington, D. C.

....... Real Estate............... New Orleans, La.

Rhodes, J. E., Secy.-Mgr....... Southern Pine Assn........... New Orleans, La.

Rolf, A. F.............. Dept. of Agriculture......... Baton Rouge, La.

Reuter, Chris.............. Vegetables and Seeds. . . . . . . New Orleans, La.

Rileyy, J. N., Sales Agt......... Atlas Powder Co. .......... New Orleans, La.

Redhead, John A., Actg. State

Agt.................... S. Dept. of Agriculture..... Baton Rouge, La.

Richardson, E. S. . . . . . . . La. State University. . . . . . . Baton Rouge, La.

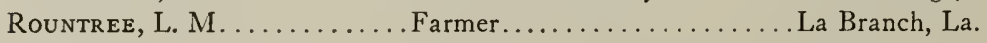

Reimers, F. W., Gen. Mgr...... Natalbany Lbr. Co. ......... Hammond, La.

Root, L. Carroll................ O. Assn. of Commerce...... New Orleans, La.

Radway, C. W., Dairy Specialist.Live Stock Exten. Service. . . . Baton Rouge, La.

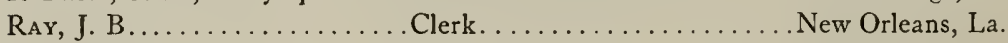

Riggs, Whit .............. Richard \& Riggs. . . . . . . . Covington, La.

Ross, W. I., Farm Supt. ...... Industrial Lbr. Co.......... Elizabeth, La.

Regal, H. W., S. A.......... L. R. \& N. Co. . . . . . . . . New Orleans, La.

Runte, E. O.............. D. P. A............... New Orleans, La.

Ranson, John I., Vice-Pres..... Naval Stores............... Abita Springs, La.

SESSOMS, ALEX. K., Pres. . . Ga. Land Owners' Assn. . ... . Cogdell, Ga.

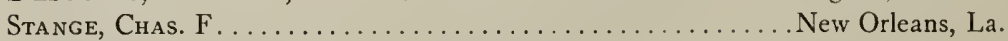

Sheppard, C. C., Gen. Mgr..... Forest Lbr. Co............ Oakdale, La.

Slagle, C. E., Gen. Mgr....... Central Lbr. Co........... Clarks, La.

SAUPE, L. E., Im. Agt......... St. Louis S. W. Ry.......... St. Louis, Mo.

Salmar, Clarke........... New Orleans Item.......... New Orleans, La.

Serferth, Herman J. . . . . . Times Picayune........... New Or'eans, La.

SANFord, F. L.............. Yellow Pine Saw Mill......... Zona, La.

Spen, C. F., Secy........... Turp. \& Rosin Prod. Assn..... New Orleans, La. 
Simmons, H., Official Reporter. New Orleans, La.

Simins, Geo. A., Publicity. .New Orleans, La.

Stonebraker, F. E., Secy... Sou. Alluvial Land Assn.

Memphis, Tenn.

Staples, C. H., Dairy Spec..... La. State University .......... Baton Rouge, La.

Sweet, J. A............... Sessoms Land \& Sec. Co...... Cogdell, Ga.

Sмith, G. K., Mgr........... Simonds Mfg. Co........... New Orleans, La.

Stevens, F. W., Mgr........... Bagdad Land \& Lbr. Co....... Bagdad, Fla.

Stern, Percival, Pres......... Interstate Electrical Co. . . . . . New Orleans, La.

Smith, T. F., Land Mgr.... . . E. Ed. Hines Lumber Co........ Poplarville, Miss.

Shelton, T. J., Traffic Mgr........ \& L. M. Ry.............. Monroe, La.

Stier, E. V., Newspaper Rep. . The Daily States.......... New Orleans, La.

Schnetzer, J., Photographer.

New Orleans, La.

Sherman, C. W., Dist. Mgr...

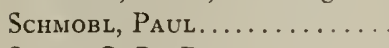

Swift, G. R., Pres.

Aetna Explosives Co...

New Orleans, La.

Chemical Engineer.

Mobile, Ala.

Sowers, W. J., Secy.-Mgr .

Swift Lbr. Co

Knoxo, Miss.

. Major-Sowers Lbr. Co. ........ Epley, Miss.

Shilstone, H. M., Rep. .

N. O. Assn. of Com...

New Orleans, La.

Stoddard, W. L., Priv. Sec.

Scott, J. H., Gen. Mgr....

Smith, E. I., Insp. in Charge

Tick Erad. in La.........

SEE, J. G., Teacher.

Schneidau, P. Sefton.

Sмith, F. L., Sales Mgr.

Staples, A. L.

Stern, Geo. M

Mr. Vrooman

Southern Mineral \& Land Imp.

Co..................Winnfield, La.

U. S. Bureau An. Industry. Agrl. College L. S. U.....

Real Estate.

Natalbany Lbr. Co.

Banker

Broker

Gen. Land Office

Great Southern Lbr. Co.

Thompson Bros. Lbr. Co.

. Pickering Land \& Tbr. Co.

Crossett Lbr. Co. .

Hort. La. Experiment Sta.

Gulf Colorado \& St. Fe Ry.

Natalbany Lbr. Co..........

U. S. Dept. Agr. Forage Crop, Investigation............

.Alaflamiss. ............... Mobile, Ala.

TAYLOR, H. W., M. D., Secy.

Тoвie, C. W., Mgr.

Wm. J. Burns Detective Agcy..New Orleans, La.

TUCKER, WM

Farmer.

Thomas, A. J., Capt

Supt. of Transportation.

Temerton, R. W., Asst. Secy.

Tuls, J. H., Agri. Agent.

Gulf Lumber Co

. K. C. S. Ry ................ Mena, Ark.

Thatcher, N. E.

Times-Picayune.
Tucker, La.

New Orleans, La.

E. St. Louis, Ill.

Baton Rouge, La.

Baton Rouge, La.

Orleans, La.

Mobile, Ala.

. New Orleans, La.

Washington, D. C.

Cravens, La.

Crossett, Ark.

Baton Rouge, La.

Pineland, Tex.

Hammond, La.

New Orleans, La.
UCKER, CLEMEN'T S.. Vice-

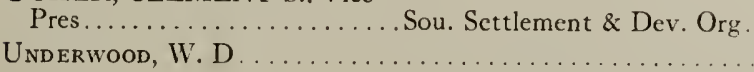


Uber, J. E................ Agricultural Engr........... New Orleans, La.

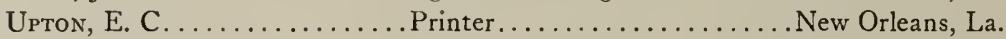

VROOMAN, CARL...........Asst. Secy. of Agriculture.....W Washington, D. C. VAN Pelt, A. W., Asso. Editor. .Gulf States Farmer.......... New Orleans, La.

WILSON, H. D............ Com. of Agr. \& Immigration... Baton Rouge, La.

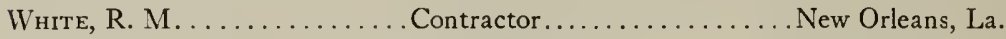
Weeks, G. C.............. Land Owner............. Hammond, La. White, H. L., Pres........... J. J. White Lbr. Co......... Columbia, Miss. Watson, D. L., Phy. \& Far.... Cusach Bldg.............. New Orleans, La. Woolsey, Walter E. ......... Farmer \& Fruit Raiser........ Rochester, N. Y. WoMAck, MARK, Agriculturalist.Teacher................. Verda, La.

Weston, J. H................. Weston Lbr. Co..........Logtown, Miss. Woolman, C. E., Dist. Agt.....Farm Demonstration Work.... Baton Rouge, La. Whittington, W. W., JR., Secy.Enterprise Lbr. Co. ......... Alexandria, La. Weigand, F., A. M............. Mercurio Pub. Co........... New Orleans, La. Wild, E. O., Editor.......... Gulf States Farmer......... New Orleans, La. Welty, D. C., Comr. of Agr . ... Missouri Pacific Ry.......... St. Louis, Mo. Walden, C. E., Vice-Pres.......Sabine Tram Co........... Beaumont, Tex. Williams, H. S., Dir. Pub...... Mississippi Cent. Expo........Gulfport, Miss. Weaver, S. P.............Weaver Bros............. Shreveport, La. Womack, F. J., Mgr. . . . . . . . Foster Lbr. Co............ Houston, Tex. Wright, W. C.............. Lumber Trade Journal. ........ New Orleans, La. Watson, Geo. E., Secy......... Sou. Cyp. Mfrs. Asso......... New Orleans, La.

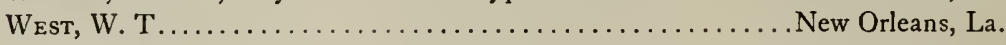

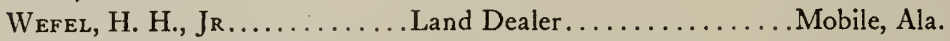
Wright, Tumer, Field Agent. . .U. S. Dept. of Agriculture..... Baton Rouge, La. Willanghly, Chas. D., Cashier. First National Bank......... Mobile, Ala.

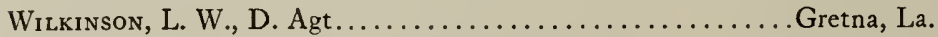

YOUNG, H. M., Treas......... Southern Pine Assn.......... New Orleans, La. Young, SAM'L............................. En Orleans, La. 


\section{DAY USE}

\section{RETURN TO DESK FROM WHICH BORROWED}

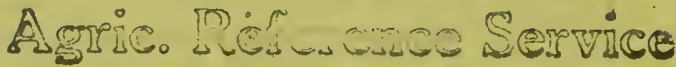

This publication is due on the LAST DATE stamped below.

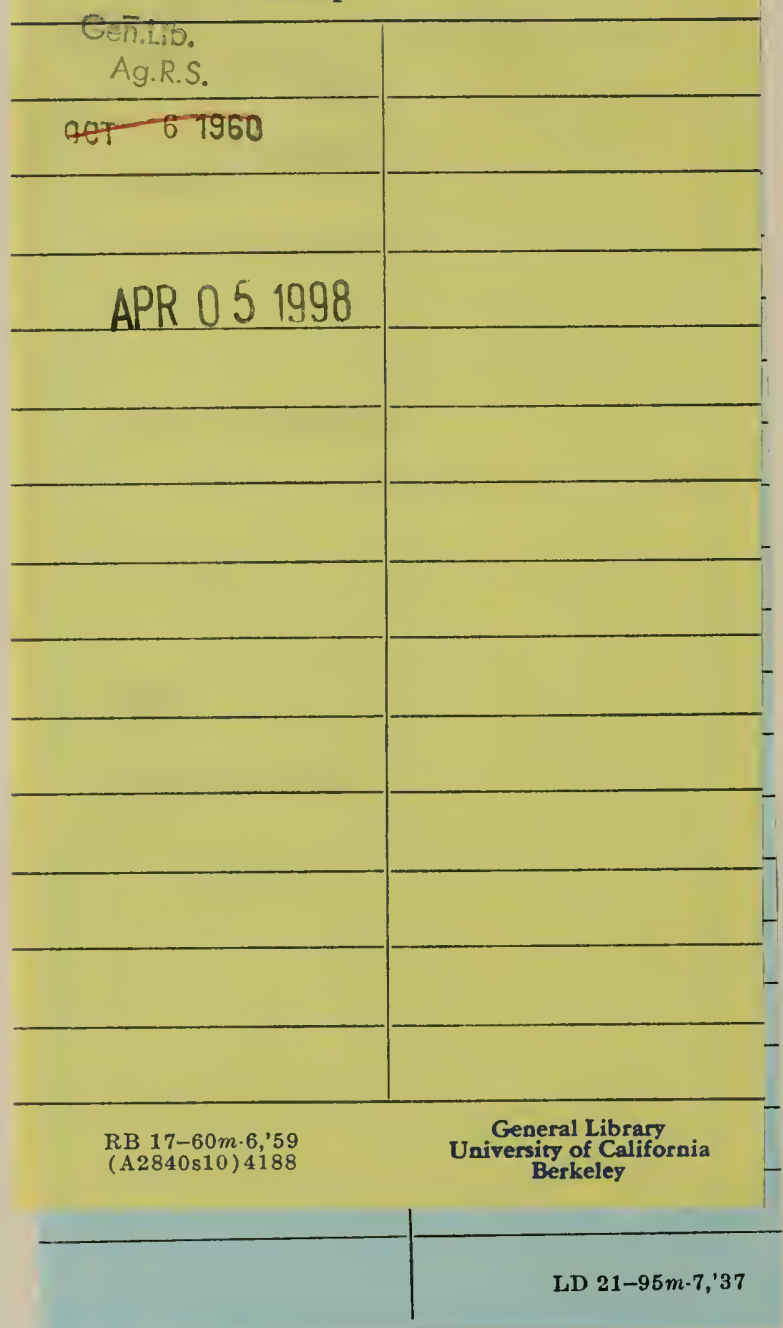


U. C. BERKELEY LIBRARIES

\section{$893 / 46$}

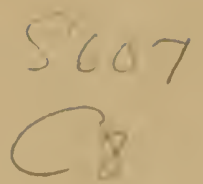

THE UNIVERSITY OF CALIFORNIA LIBRARY 
